\title{
Use and usefulness of financial accounting and auditing : the case of trade union bargainers
}

Citation for published version (APA):

Hassink, H. F. D. (2000). Use and usefulness of financial accounting and auditing : the case of trade union bargainers. [Doctoral Thesis, Maastricht University]. Datawyse / Universitaire Pers Maastricht. https://doi.org/10.26481/dis.20010209hh

Document status and date:

Published: 01/01/2000

DOI:

10.26481/dis.20010209hh

Document Version:

Publisher's PDF, also known as Version of record

\section{Please check the document version of this publication:}

- A submitted manuscript is the version of the article upon submission and before peer-review. There can be important differences between the submitted version and the official published version of record. People interested in the research are advised to contact the author for the final version of the publication, or visit the DOI to the publisher's website.

- The final author version and the galley proof are versions of the publication after peer review.

- The final published version features the final layout of the paper including the volume, issue and page numbers.

Link to publication

\footnotetext{
General rights rights.

- You may freely distribute the URL identifying the publication in the public portal. please follow below link for the End User Agreement:

www.umlib.nl/taverne-license

Take down policy

If you believe that this document breaches copyright please contact us at:

repository@maastrichtuniversity.nl

providing details and we will investigate your claim.
}

Copyright and moral rights for the publications made accessible in the public portal are retained by the authors and/or other copyright owners and it is a condition of accessing publications that users recognise and abide by the legal requirements associated with these

- Users may download and print one copy of any publication from the public portal for the purpose of private study or research.

- You may not further distribute the material or use it for any profit-making activity or commercial gain

If the publication is distributed under the terms of Article $25 \mathrm{fa}$ of the Dutch Copyright Act, indicated by the "Taverne" license above, 


\section{Use and usefulness of financial accounting and auditing}

the case of trade union bargainers 
(C) H.F.D. Hassink, Maastricht 2000 ISBN 90-9014428-5

Druk: Universitaire Pers Maastricht 


\title{
Use and usefulness of financial accounting and auditing
}

\author{
the case of trade union bargainers
}

\section{PROEFSCHRIFT}

ter verkrijging van de graad van doctor aan de Universiteit Maastricht, op gezag van de Rector Magnificus, Prof. Dr. A.C. Nieuwenhuijzen Kruseman, volgens het besluit van het College van Decanen, in het openbaar te verdedigen op vrijdag 9 februari 2001 om 14.00 uur

door

Harold Franciscus Dominicus Hassink 


\section{Promotor:}

Prof. Dr. W.F.J. Buijink

\section{Beoordelingscommissie:}

Prof. Dr. S.J. Maijoor (voorzitter)

Prof. Dr. J.A.M. Heijke

Prof. Dr. J.G. Kuijl RA

Prof. Dr. R.G.A. Vergoossen RA 


\section{Voorwoord}

Velen hebben een bijdrage geleverd aan de totstandkoming van dit proefschrift. Allen daarvoor hartelijk dank. Met als risico sommigen te vergeten wil ik een aantal mensen in het bijzonder noemen.

Op de eerste plaats mijn promotor Willem Buijink die mij de ruimte gaf voor onderzoek en op wie ik altijd een beroep kon doen. Beste Willem, jouw belangstelling voor empirisch onderzoek is enthousiasmerend en je bent erin geslaagd een vruchtbaar onderzoeksklimaat te scheppen. Jouw constructieve commentaren zijn met name ook in de laatste fase van de studie van groot belang geweest. Ik dank je ook vooral omdat je het vertrouwen niet hebt verloren. Hans Heijke, Hans Kuijl, Steven Maijoor en Ruud Vergoossen dank ik voor hun bereidheid plaats te nemen in de beoordelingscommissie en voor de moeite die zij hebben gedaan de hoofdstukken van commentaar te voorzien. Steven Maijoor en Jan van de Poel dank ik omdat zij me enthousiast hebben gemaakt voor de wetenschap. Henk Brink en Hans Kuijl dank ik omdat zij zich tijdelijk over mij ontfermden op een kritiek moment. Gerard Mertens wil ik bedanken omdat hij eerst als kamergenoot en later als buurman heeft geholpen het onderzoek op de rails te houden. Samen hebben we de eerste schreden op het wetenschappelijke pad gezet. Bedankt voor de vele stimulerende gedachtewisselingen. Laury Bollen wil ik in het bijzonder bedanken voor zijn commentaar op de empirische hoofdstukken van dit proefschrift en zijn hulp bij het oplossen van allerhande problemen, die soms direct, soms indirect maar soms ook totaal niets te maken hadden met dit proefschrift. Laury, ik kan mij niet herinneren dat ik ooit tevergeefs een beroep op jou heb gedaan, bedankt voor je hulpvaardigheid. Bram Beek dank ik voor zijn talloze adviezen op velerlei vlak. Erik de Regt dank ik voor zijn opmerkingen bij hoofdstuk 2 van dit proefschrift. De Faculteit der Economische Wetenschappen en Bedrijfskunde van de UM en het Maastricht Accounting and Auditing Research and Education Center (MARC) dank ik omdat zij het financieel mogelijk hebben gemaakt dat ik als assistent-in-opleiding de postdoctorale opleiding tot registeraccountant kon volgen. De (oud-) collegae van het MARC wil ik danken voor hun collegialiteit en hun bijdrage aan het wetenschappelijk klimaat. Dank aan allen, waaronder Els van Aernsbergen, Jos Blommaert, Tjeu Blommaert, Michael Corbey, Marcel Caubo, Roger Dassen, Rogier Deumes, Richard Dohmen, Rob Eken, Sabine Galama, Gerard van Gogh, Annet Grol, Ilse Groneschild, Tom Groot, 
Frank Hartmann, Boudewijn Janssen, Paul Janssen, Jacques Koenen, Martien Lubberink, Eric Mantelaers, Ad Marneffe, Roger Meuwissen, Frank Moers, Theo Molenbrugge, Sonja Passau, Erik Peek, Markus Schaen, Caren Schelleman, Arnold Schilder, Miranda Schoep, Yvonne Schols, Eline Steenhuysen, Leon Timmermans, Luc Quadackers, Ton van Reeken, Hanno Roberts, Eddy Vaassen, Ann Vanstraelen, Philip Vergauwen, Hans Verkruijsse, Joep Versteegh, Mark Vluggen, Frans Volmer, Niels van de Wiel, Michel Wilhelmus, Maurice Zinken. Dank ook aan hen die ik vergeten ben hier te noemen. De faculty en deelnemers van het Doctoral Colloqium van het EAA Congres in Turku, Finland dank ik voor de stimulerende gedachtewisselingen en opbouwende kritieken. Mijn jaargenoot en oud-collega Marc Gulikers wil ik danken voor de discussies over van alles en nog wat.

Bijzondere dank ben ik verschuldigd aan alle respondenten alsmede aan Henk van Rees (destijds Industriebond FNV) en Ed van Eijbergen (destijds Scholingsinstituut FNV). De toenmalige Dienst Collectieve Arbeidsvoorwaarden van het Ministerie van Sociale Zaken en Werkgelegenheid dank ik voor de hulp bij het bestuderen van de CAO's.

Mijn ouders wil ik danken omdat ze als mijn eerste leermeesters de basis hebben gelegd en dat zij me erfelijk hebben verrijkt met hun doorzettingsvermogen. Bijzondere dank gaat uit naar Kitty. Van de eerste tot de laatste dag heeft zij belangstelling getoond en me de ruimte gegeven voor het onderzoek. Tot slot dank aan Anke en Meike, just for being there.

Mijn dankbaarheid aan allen laat onverlet dat slechts ik verantwoordelijk ben voor eventuele omissies of fouten in dit proefschrift.

Harold Hassink

Maastricht, oktober 2000 


\section{Contents}

List of Abbreviations

1 Introduction $\quad 13$

1.1 General introduction 13

$\begin{array}{lll}1.2 & \text { Trade unions as employees' agents } & 14\end{array}$

1.3 Trade unions as potential users of accounting information in corporate annual reports $\quad 15$

1.4 Motivation, research questions and research approach $\quad 16$

1.5 Contents of the dissertation 18

Notes 21

2 The potential relevance of accounting and auditing:

the case of trade union bargainers 23

2.1 Introduction 23

2.2 A contracting cost based perspective on the relevance of accounting information to trade union bargainers

2.3 Perspectives used in the empirical financial accounting literature on the relevance of accounting information to trade union bargainers

2.4 A synthesis $\quad 34$

2.5 The potential relevance of auditing to trade union bargainers 36

$\begin{array}{lll}2.6 & \text { Conclusions } & 37\end{array}$

$\begin{array}{ll}\text { Notes } & 38\end{array}$

3 An overview of previous research and four research opportunities

3.1 Introduction 41

3.2 Empirical research in accounting, auditing and collective wage bargaining 41

3.3 Evaluation 55

3.4 Four research opportunities and this dissertation 56

Notes $\quad 60$ 
4 The role of accounting and auditing in contracts:

a study of non-executive employee contracts 61

4.1 Introduction 61

4.2 Theoretical framework 62

4.3 Relations to previous empirical research 62

4.4 Development of the research questions and hypotheses 63

4.5 Research method and data description 64

4.6 The role of accounting and auditing in CBCs: empirical results 65

4.7 The role of accounting and auditing in EPSPs: empirical results $\quad 68$

$\begin{array}{lll}4.8 & \text { Summary and overall conclusions } & 73\end{array}$

App.4A Summary of EPSPs studied $\quad 76$

Notes $\quad 77$

5 The use and perceived importance of corporate annual reports: a study among trade union bargainers $\quad 81$

$\begin{array}{lll}5.1 & \text { Introduction } & 81\end{array}$

$\begin{array}{lll}5.2 & \text { Theoretical framework } & 82\end{array}$

5.3 Relations to previous empirical research 83

5.4 Development of the hypotheses 85

$\begin{array}{lll}5.5 & \text { Research method and respondents' characteristics } & 88\end{array}$

$\begin{array}{ll}\text { 5.6 The use of CARs: empirical results } & 91\end{array}$

5.7 The perceived importance of CARs: empirical results 95

5.8 The perceived importance of the consolidated income

$\begin{array}{lll}5.9 & \text { Summary and overall conclusions } & 103\end{array}$

$\begin{array}{lll}\text { App.5A Relevant part of the questionnaire } & 107\end{array}$

App.5B Test for non-response bias 108

$\begin{array}{ll}\text { Notes } & 109\end{array}$

6 The audit expectations gap: a study among trade union $\begin{array}{ll}\text { bargainers } & 111\end{array}$

$\begin{array}{lll}6.1 & \text { Introduction } & 111\end{array}$

$\begin{array}{lll}6.2 & \text { Theoretical framework } & 113\end{array}$

6.3 Relations to previous empirical research 113

6.4 Development of the hypotheses 114

$\begin{array}{lll}6.5 & \text { Research method and respondents' characteristics } & 117\end{array}$

$\begin{array}{lll}6.6 & \text { The performance gap: empirical results } & 120\end{array}$

$\begin{array}{lll}6.7 & \text { The standards gap: empirical results } & 126\end{array}$

6.8 The reasonableness gap: empirical results 129

$\begin{array}{lll}\text { 6.9 Summary and overall conclusions } & 132\end{array}$

App.6A Relevant part of the questionnaire 135 
$\begin{array}{lll}\text { App.6B Test for non-response bias } & 137\end{array}$

$\begin{array}{ll}\text { Notes } & 138\end{array}$

7 The independence of auditors: a study among trade union bargainers 141

$\begin{array}{lll}7.1 & \text { Introduction } & 141\end{array}$

$\begin{array}{lll}7.2 & \text { Theoretical framework } & 142\end{array}$

7.3 Relations to previous empirical research 143

7.4 Development of the hypotheses 145

7.5 Research method and respondents' characteristics 149

7.6 The auditor independence gap: empirical results 151

$\begin{array}{lll}7.7 & \text { Summary and overall conclusions } & 156\end{array}$

App.7A Relevant part of the questionnaire 159

$\begin{array}{lll}\text { App.7B Test for non-response bias } & 160\end{array}$

Notes 161

$8 \quad$ Summary and discussion $\quad 163$

$\begin{array}{lll}8.1 & \text { Introduction } & 163\end{array}$

$\begin{array}{lll}8.2 & \text { Summary } & 163\end{array}$

$\begin{array}{lll}8.3 & \text { Limitations } & 168\end{array}$

$\begin{array}{lll}8.4 & \text { Suggestions for future research } & 169\end{array}$

$\begin{array}{lll}8.5 & \text { Policy implications } & 171\end{array}$

App.A A note on financial accounting and auditing in the Netherlands

App.B Introduction to collective wage bargaining in the 179 Netherlands

App.C The contents of collective bargaining contracts: two examples

App.D A note on trade unions' interest in corporate annual reports: the case of the Dutch Enterprise Chamber

References

Nederlandstalige samenvatting

Curriculum vitae 


\section{List of Abbreviations}

\begin{tabular}{|c|c|}
\hline AAA: & American Accounting Association \\
\hline ACCA: & Association of Chartered Certified Accountants \\
\hline AEG: & Audit expectations gap \\
\hline Al: & Auditor independence \\
\hline AICPA: & American Institute of Certified Public Accountants \\
\hline AIG: & Auditor independence gap \\
\hline AIM: & Asymmetric Information Model \\
\hline AJM: & Ashenfelter and Johnson Model \\
\hline ARBO-Law: & Law on Labour Conditions (Wet op de arbeidsomstandigheden) \\
\hline BV: & Private company limited by shares (besloten vennootschap) \\
\hline CAR: & Corporate annual report (financieel jaarverslag) \\
\hline $\mathrm{CBC}$ : & Collective bargaining contract $(C A O)$ \\
\hline CBS: & Central Statistical Bureau (CBS) \\
\hline CCT: & Contracting Cost Theory \\
\hline CICA: & Canadian Institute of Chartered Accountants \\
\hline CIS: & $\begin{array}{l}\text { Consolidated income statement (geconsolideerde winst- en } \\
\text { verliesrekening) }\end{array}$ \\
\hline CL-bargaining: & $\begin{array}{l}\text { Corporate-level bargaining (onderhandelingen op } \\
\text { ondernemingsniveau) }\end{array}$ \\
\hline CL-contract: & Corporate-level contract (ondernemings-CAO) \\
\hline CNV: & $\begin{array}{l}\text { Christian National Trade Union Federation (Christelijk Nationaal } \\
\text { Vakverbond) }\end{array}$ \\
\hline EC: & Enterprise Chamber (Ondernemingskamer) \\
\hline EDUC: & Level of education of the trade union bargainer \\
\hline EPSP: & Employee profit sharing plan (winstdelingsregeling) \\
\hline FNV: & $\begin{array}{l}\text { Federated Dutch Trade Union Movement (Federatie Nederlandse } \\
\text { Vakbeweging) }\end{array}$ \\
\hline HM: & Hicks Model \\
\hline IASC: & International Accounting Standards Committee \\
\hline ICAI: & Institute of Chartered Accountants in Ireland \\
\hline ICAEW: & Institute of Chartered Accountants in England and Wales \\
\hline IL-bargaining: & Industry-level bargaining (onderhandelingen op bedrijfstakniveau) \\
\hline IL-contract: & Industry-level contract (bedrijfstak-CAO) \\
\hline IMPATP: & $\begin{array}{l}\text { Perceived importance of ability to pay as an argument in making wage } \\
\text { claim decisions }\end{array}$ \\
\hline IMPCAR: & Perceived importance of CARs \\
\hline IMPCI: & Perceived importance of company specific information \\
\hline IMPCIS: & Perceived importance of the consolidated income statement \\
\hline IO: & Internal organisation \\
\hline MAS: & Management advisory services \\
\hline
\end{tabular}




$\begin{array}{ll}\text { LEVEL: } & \text { Bargaining-level (corporate-level versus industry-level) } \\ \text { MHP: } & \text { Trade Union for Middle and Higher-level Employees (Vakcentrale } \\ & \text { voor Middelbaar en Hoger Personeel) } \\ \text { MUM: } & \text { Monopoly Union Model } \\ \text { NCW: } & \text { Dutch Christian Employers' Federation (Nederlands Christelijk } \\ & \text { Werkgeversverbond) } \\ \text { NIVRA: } & \text { Royal Netherlands Institute for Registered Accountants (Koninklijk } \\ & \text { Nederlands Instituut van Registeraccountants) } \\ \text { NOVAA: } & \text { Netherlands Order of Accountants-Administrative Consultants } \\ & \text { (Nederlandse Orde van Accountants-Administratieconsulenten) } \\ \text { NV: } & \text { Public limited liability company (naamloze vennootschap) } \\ \text { PERFGAP: } & \text { Performance gap } \\ \text { REASONGAP: } & \text { Reasonableness gap } \\ \text { RJ: } & \text { Council for Annual Reporting (Raad voor de Jaarverslaggeving) } \\ \text { SER: } & \text { Social Economic Council (Sociaal Economische Raad) } \\ \text { STANDGAP: } & \text { Standards gap } \\ \text { SUPROT: } & \text { Support for a mandatory auditor rotation } \\ \text { TEN: } & \text { Length of tenure as a trade union bargainer } \\ \text { TOLFEE: } & \text { Tolerance for the client-fee relation } \\ \text { TOLMAS: } & \text { Tolerance for providing management advisory services to audit clients } \\ \text { TUA: } & \text { Trade union affiliation } \\ \text { USECAR: } & \text { Use of CARs by trade union bargainers } \\ \text { VNO: } & \text { Federation of Dutch Industries (Verbond van Nederlandse } \\ & \text { Ondernemingen) } \\ \text { WJO: } & \text { Law on the Annual Financial Statements of Companies (Wet op de } \\ & \text { jaarrekening van ondernemingen) } \\ \text { WOR: } & \text { Law on the Works Councils (Wet op de ondernemingsraden) } \\ \text { WMcKM: } & \text { Walton and McKersie Model }\end{array}$




\section{Chapter 1 \\ Introduction}

\section{$1.1 \quad$ General introduction}

In the late $1960 \mathrm{~s}$, researchers became interested in the usefulness of accounting information in corporate annual reports. This led to the development of new lines of empirical research. In one line the focus is on capital market responses to the release of accounting information. In a second line the focus is on the usefulness of corporate annual reports to potential users. Most of the latter (survey-based) work studies the perceptions of shareholders, investors and investment analysts. This dissertation is a contribution to the second line of research.

This dissertation is motivated by a desire to gain a better understanding of the use and usefulness of financial accounting and auditing not from the perspective of the providers of financial capital, but from the perspective of the providers of human capital, in particular trade union bargainers.'

Accounting information in corporate annual reports is only useful if it is perceived as reliable, and therefore accounting information is subject to independent audits. As a consequence, the usefulness of accounting information also depends on users' perceptions of audits and auditors. Therefore, we will also study trade union perceptions of audits and auditors.

Within the purposes of this dissertation, we will deal with accounting, auditing, collective wage bargaining and with their interfaces. The principal approach is an accounting approach.

The aim of this introductory chapter is to formulate the problems studied, to clarify the key concepts, and to outline the methodology used. The chapter is organised as follows. Section 1.2 presents trade unions as employees' agents. Section 1.3 introduces trade union bargainers as potential users of accounting information in corporate annual reports, and of audits. Section 1.4 presents the motivation for this dissertation and introduces the research questions that will be addressed in the empirical part of the work. It also presents the research approach. Finally, Section 1.5 
provides an overview of the dissertation.

\section{$1.2 \quad$ Trade unions as employees' agents}

Economic theory portrays trade unions as agents of employees. ${ }^{2} \mathrm{~A}$ trade union may be defined as:"

"any organisation, whose membership consists of employees, which seeks to organise and represent their interest both in the workplace and society and, in particular, seeks to regulate their employment relationship through the direct process of collective bargaining with management."

Mainstream analysis hypothesises that trade unions aim to increase the material welfare of their members by improving working conditions and raising wages above the competitive level. Trade unions are able to accomplish this by threatening to inflict damage on the company by mobilising employees to industrial action.

Trade unions can provide three general kinds of benefits to their members: (1) information and contract services, (2) governance services and (3) voice."

(1) Information and contract services provided by the trade union include bargaining over pay and working hours, and informing employees on pensions and the like. These benefits may be both collective and private.

(2) Governance services involve monitoring the follow-up to previous agreements. The trade union may use its power and resources to detect opportunistic behaviour on the part of executive management and to respond to this.

(3) The trade union acts as a communication channel through which individual employees can communicate their preferences regarding wages and working conditions to the employer.

There are economies of scale in the provision of these agency services. This explains the emergence of trade unions. In Chapter 2 we will use the portrayal of trade unions and specifically trade union bargainers as agents to provide the motivation for this dissertation. 


\section{Trade unions as potential users of accounting information in corporate annual reports}

In the Netherlands companies over a certain size are obliged to publish corporate annual reports. ${ }^{6}$ According to the International Accounting Standards Committee (IASC), the objective of corporate annual reports is to:?

"provide information about the financial position, performance and changes in financial position of an enterprise that is useful to a wide range of users in making economic decisions."

It is often claimed that the wide range of users of corporate annual reports also includes employee representatives. According to the IASC:"

"the users of financial statements include present and potential (...) employees (...) Employees and their representative groups are interested in information about the stability and profitability of their employers. They are also interested in information which enables them to assess the ability of the enterprise to provide remuneration, retirement benefits and employment opportunities."

Employee representatives, of course, include trade unions and trade union bargainers.

Leading textbooks on financial statement analysis, as well as standard setting organisations, draw attention to the usefulness of corporate annual reports in employee contracting. According to Foster (1986, p.4):

"the demand for financial statements by employees can arise from several motivations. Employees have a vested interest in the continued and profitable operations of their firm; financial statements are an important source of information about current and potential future profitability and solvency. Employees can also demand financial statements to monitor the viability of their pension plans."

Rees $(1995$, p.6) takes a European perspective:

"employees and trade unions in the UK are concerned principally with job security and wage negotiations. In continental Europe they are often also involved in consultation with management. In both cases the union/employee may use financial information as an input to negotiations for predicting future employment levels."

Despite all of this, there has been little research in the empirical financial accounting and auditing literature on the question of whether trade union bargainers consider accounting information and auditing useful. 


\subsection{Motivation, research questions and research approach}

\subsubsection{Motivation}

It is interesting to note that trade union bargainers have not attracted much attention from accounting researchers, while the accounting literature does portray trade unions as an interesting research subject. Craft $(1984$, p.107) refers to this area of research as:

"(...) the undernourished intersection between accounting and industrial relations."

And Chow et al. (1988, p.183) identify several research opportunities, including: "Do unions use audited [corporate annual] reports and in what manner?"

Amernic and Aranya (1990, p.21) also stress the importance of more research in this field:

"The intersection of accounting and industrial relations is an area in need of a sustained research program."

We believe it is meaningful to investigate the usefulness of accounting information and auditing to trade union bargainers. We do this in the setting of collective wage bargaining for two reasons. First, in the Netherlands, collective wage bargaining is the dominant process through which wealth is allocated among a company's stakeholders and a substantial number of employees are significantly affected by the outcome of collective wage bargaining. Furthermore, shareholders, as residual claimants, also have an interest in bargaining results; this further justifies our effort. Second, we expect accounting information in corporate annual reports to become even more important to trade union bargainers in the coming years, because collective wage bargaining in the Netherlands is decentralising, and profit sharing plans for employees seem to gain popularity.

\subsubsection{Research questions}

Although the dissertation aims to contribute to the general exploration of the accounting, auditing and collective wage bargaining arena, it is essentially concerned with four specific research questions. These questions are derived based on the review of the empirical financial accounting and auditing literature that focuses on collective wage bargaining. This review can be found in Chapter 3 of this dissertation.

Each of the four empirical essays in this dissertation addresses one main question, 
which is then split into more detailed questions and hypotheses. Although the essays are linked to the central theme of this dissertation, they are intended as separate studies.

The first two essays explore the use and usefulness of accounting information in corporate annual reports. The other two essays focus on the perceptions on audits and auditors. The following research questions will be addressed:

(1) What is the role of accounting and auditing in collective bargaining contracts and employee profit sharing plans, and what explains the variation of this role? (Chapter 4)

(2) Do trade union bargainers use corporate annual reports and do they perceive corporate annual reports as important, and if so, what explains the variation in usage and perceived importance? (Chapter 5)

(3) Do trade union bargainers have an audit expectations gap, and if so, what explains the variation in the gap? (Chapter 6)

(4) What are trade union bargainers' perceptions of auditor independence and what explains the variation in these perceptions? (Chapter 7).

The aim of this dissertation is to add to the research literature in five respects: (1) by posing alternative research questions, (2) by exploring an alternative institutional setting, (3) by using an alternative set of data, (4) by using alternative research designs, and (5) by investigating the explanatory power of alternative variables.

(1) Chapters 4, 6 and 7 address research questions that, to our knowledge, have not been addressed before.

(2) In contrast to most previous work, which is rooted in the setting of US and UK industrial relations, this dissertation uses the Dutch setting. Within the Dutch framework, collective wage bargaining can take place on a corporate or on an industry-level. The empirical part of this dissertation explicitly explores the impact of corporate versus industry-level bargaining on the use of accounting information in corporate annual reports and on trade union bargainers' perceptions of audits and auditors. In corporate-level bargaining, trade unions face companies directly and are expected to rely more heavily on company-related data compared to industry-level bargaining, ceteris paribus.

(3) This dissertation studies the perceptions of trade union officials actually involved in collective wage bargaining, instead of those of trade union leaders or nontrade union subjects, as has been done by others in interviews and in experiments. ${ }^{10}$ Chapter 4 investigates the contractual arrangements between employers and trade 
unions to learn more on the role accounting information and auditing in explicit contracts. As far as we know, focusing on collective bargaining contracts to investigate the role of financial accounting and auditing in industrial relations is new in the literature.

(4) Chapters 4, 5, 6 and 7 adopt research designs used in related research areas but which are new in the setting of collective wage bargaining. Consequently, the findings of these chapters can be compared to previous research on the usefulness of accounting information and corporate annual reports among other interest groups.

(5) Finally, in Chapters 5,6 and 7 the variations in the perceptions of trade union bargainers is investigated by testing the explanatory power of a set of bargainerrelated variables: trade union affiliation, length of tenure as a trade union bargainer and level of education. This provides an analytical setting that is more powerful than the analysis of a homogeneous group of bargainers. Studying the impact of bargainerrelated variables on the use and usefulness of accounting information in corporate annual reports and on the perceptions of audits and auditors is also new.

\subsubsection{Research approach}

Theory is important in understanding the use and usefulness of accounting information. In the words of Watts and Zimmerman (1986, p.2):

"The objective of accounting theory is to explain and predict accounting practice."

There are several approaches to accounting theory." This dissertation falls within the decision-usefulness approach. This approach is descriptive rather than normative. Consequently, we will basically provide descriptions of the phenomena studied, rather than employing value judgements.

\subsection{Contents of the dissertation}

We conclude this introductory chapter with an outline of the remainder of this dissertation.

This dissertation is composed of an introductory part (Chapters 1-3), an empirical part (Chapters 4-7), a closing chapter (Chapter 8), and a supplementary part (Appendices A to D). 
The four empirical essays form the heart of this dissertation. All empirical chapters start with an extensive introduction and can be read more or less independently.

Chapter 2 posits that accounting information and auditing are potentially useful to trade unions in the setting of collective wage bargaining. It reviews two sets of theoretical approaches to the use of accounting information by trade unions. The first set consists of a contracting costs theory-based explanation of trade unions' use of accounting information. The second set is a collection of theories of collective wage bargaining presented in the empirical financial accounting literature. Based on these sets of theoretical approaches Chapter 2 also provides arguments why auditing is potentially useful to trade unions.

Chapter 3 positions this dissertation in the literature. It presents the findings of earlier empirical work on (1) the usefulness of accounting information to trade unions, (2) the impact of accounting information on the process and outcome of collective wage bargaining, (3) the effect of collective wage bargaining on the process of financial accounting, and (4) on the perceptions of trade unions on independent auditors. Based on the evaluation of previous empirical research, this chapter identifies four research opportunities. Chapters 4 to 7 address these opportunities.

Chapter 4 explores and documents the roles and relative importance of accounting information and of auditing in collective bargaining contracts and employee profit sharing plans. For this purpose, samples of collective bargaining contracts $(\mathrm{N}=1,332)$ and employee profit sharing plans $(\mathrm{N}=63)$ will be screened. Content analysis will be used to study the accounting and auditing parameters of the employee profit sharing plans. This social science based research methodology is particularly suitable for studying the contents of contracts.

Chapter 5 reports the findings of an empirical study on the use and perceived importance of corporate annual reports. The study is based on a survey among trade union bargainers $(\mathrm{N}=101)$. This chapter documents the extent to which corporate annual reports are used in collective wage bargaining, and the perceptions of trade union bargainers on the relative importance of corporate annual reports, and of the income statement. This chapter attempts to explain the variation of the dependent variables by investigating the impact of bargaining level and a set of control variables. Both univariate and multivariate analysis will be conducted.

Chapter 6 investigates the existence and nature of the audit expectations gap. As in previous work, this chapter will investigate the perceptions of the performance of existing auditor duties and the need for performing non-existing duties. To map the audit expectations gap, trade union bargainers will be surveyed $(\mathrm{N}=104)$. Again, the 
intention is to investigate the power of bargaining level and that of a set of control variables in explaining the variation in the audit expectations gap. Univariate and multivariate analysis will be conducted here as well.

Chapter 7 reports the results of an empirical study on the perceptions of auditor independence. Independence is the most important ethical requirement of auditors. Studying the perceptions of independence provides further understanding on the reliability, and therefore on the usefulness of accounting information in corporate annual reports. The perceptions of auditor independence of a panel of trade union bargainers $(\mathrm{N}=104)$ will be analysed. The focus here will also be on the power of bargaining level and a set of control variables to explain the variation in the perception of auditor independence. Again, univariate and multivariate analysis will be conducted.

Chapter 8 is the closing chapter of this dissertation. It will summarise the main findings, discuss the limitations of the dissertation, provide some suggestions for future research, and present some policy implications.

A set of appendices provide background information to the empirical chapters. To interpret the research findings, it is important to understand the basics of the Dutch financial accounting and auditing requirements and of the Dutch system of collective wage bargaining. Two appendices have been added specifically for readers with a background in either accounting or industrial relations: one on financial accounting and auditing in the Netherlands (Appendix A) and one on collective wage bargaining in the Netherlands (Appendix B). For the purposes of illustration, Appendix C presents the contents of two collective bargaining contracts. Finally, Appendix D analyses two cases brought before the Dutch Enterprise Chamber. In both cases, trade unions filed a charge of failure to comply with financial accounting law, and demanded restatement of the corporate annual report. This appendix aims to shed light on the views that politicians, trade unions, companies and legal authorities have concerning trade unions' interest in corporate annual reports, and consequently on whether the unions may take legal action to force companies to prepare their corporate annual report in accordance with directions to be given by the Enterprise Chamber. Appendix D attempts to provide additional evidence on the relevance of corporate annual reports to trade unions. 


\section{Notes}

1. Another possibility would be to study the usefulness of accounting information to individual employees. We will not do this because this issue has been addressed previously from various directions. For overviews of research in this area see Lewis et al. (1984), Gray et al. (1987), Parker (1988), Parker et al. (1988).

2. Conflicts of interest between principals and agents are inherent in agency relations. This section ignores the potential conflicts between union leaders and union members. For discussions on this see Faith and Reid (1987) and Booth (1995, p.111).

3. See Salamon (1998, p.85).

4. See Faith and Reid (1987).

5. Employees can free ride on collective benefits but not on private benefits. This may provide a motivation to become a trade union member even in the absence of coercion (see Booth, 1995, p.74).

6. See also Appendix A of this dissertation for a brief introduction to the financial accounting and auditing requirements for Dutch companies.

7. IASC, International Accounting Standards 1999. Framework for the Preparation and Presentation of Financial Statements (1999, Paragraph 12, p.44).

8. IASC, International Accounting Standards 1999, Framework for the Preparation and Presentation of Financial Statements (1999, Paragraph 9, p.42).

9. See also Appendix B of this dissertation for an introduction to collective wage bargaining and trade unions in the Netherlands.

10. See also Chapter 3 of this dissertation for an overview of the research.

11. For overviews of accounting theories see AAA (1977) and Whittington (1986). 
$\underline{22}$

Chapter 1: Introduction 


\section{Chapter 2 \\ The Potential Relevance of Accounting and Auditing: The case of trade union bargainers}

\section{$2.1 \quad$ Introduction}

Because the relevance of accounting information and auditing to trade unions has not been studied much, theory underlying the usefulness of accounting information and auditing to trade unions is scattered.' Amernic (1988) is among the researchers in the area of accounting and collective wage bargaining who stress the need for such theory:

"An important preliminary to the research enterprise in this area-indeed in any area- is that the researcher must have a weltanschaung (or worldview) of the phenomenon in question."

This chapter presents a series of theoretical approaches to the potential relevance of accounting information to trade unions. At the end of this chapter also the potential relevance of auditing to trade unions will be discussed.

The purpose of this chapter is not to develop new theory. The purpose is more narrow. The objective is to make it plausible that accounting information and auditing are potentially relevant to trade unions in collective wage bargaining.

Section 2.2 sketches a general, contracting cost based theory of the relevance of accounting information to trade unions. This theory was not developed for the specific purpose of explaining the relevance of accounting information to trade unions, yet it may be used for this purpose. In Section 2.3 brief descriptions will be provided of theoretical approaches used in previous empirical financial accounting research on the relevance of accounting information to trade unions. The empirical findings themselves will be presented in Chapter 3 of this dissertation. Subsequently, Section 2.5 discusses the potential relevance of auditing to trade union bargainers. Finally, Section 2.6 presents some conclusions.

It will be seen that both general contracting cost theory, and theory used in previous 
empirical financial accounting research, make it plausible that accounting information is potentially relevant to trade union bargainers.

One alternative theory questions the potential relevance of accounting information to trade union bargainers. In that perspective, accounting information is seen as a tool of social domination. Though empirical research building on this perspective is lacking, this perspective will be sketched at the end of the chapter.

Note that the theoretical approaches discussed here may be overlapping as well as complementary.

\subsection{A contracting cost based perspective on the relevance of accounting information to trade union bargainers}

Contracting cost theory (CCT) is economics based. ${ }^{2}$ It portrays the company as a nexus of contracts between self-interested stakeholders. Stakeholders potentially take actions that are utility maximising at the personal level and value reducing at the collective level.' Opportunistic behaviour may be penalised. If management, for instance, refuses to restrict the consumption of perquisites, shareholders can priceprotect themselves by lowering the compensation of management. Analogously, if management fails to reduce the information asymmetry, trade unions may demand higher wages, extent the scope of collective wage bargaining or prepare employees for industrial actions. CCT then assumes that parties have incentives to restrict the possibilities to behave opportunistically. Managers for instance, may increase the present value of their compensation by lowering agency costs, e.g. by disclosing accounting information voluntarily, or by engaging auditors to determine the reliability of the accounting information disclosed. ${ }^{4}$

Competition forces companies and stakeholders to design efficient contracts and monitoring mechanism. CCT assumes that efficient contracts minimise agency costs and maximise the value of the company. Companies with sub-optimal contracts will under-perform and, unless there are some offsetting benefits, they will disappear in the long run.

The need for efficient contracts not only exists in financial contracting, but in employee contracting as well. Employees may bargain with management themselves, or employees may hire agents to bargain with management on their behalf. For most non-executive employees contracting takes place at the collective level. Bargaining at this level limits uncertainty and decreases contracting costs compared to individual bargaining. ${ }^{5}$ Given the need and continuous search for efficient contracts, collective 
bargaining contracts change over time. The appearance, for instance, of employee profit sharing plans in collective wage bargaining contracts can be explained from the need to reduce agency costs in employee contracting. ${ }^{6}$ Accounting numbers are typically used to construct employee profit sharing plans.

From a CCT perspective therefore, the possible role of accounting in collective wage bargaining is twofold. First, accounting information may serve as an input in contractual decision making. Since the position of trade unions depends on the support of their members, trade unions must assess employees' wage targets and resistance points.? If these are based upon "how well the company is doing" accounting information concerning the performance of the company may well be used by trade unions." Second, accounting information may also be used to construct contracts. Employee bonus plan formulas are typically based on some profit indicator and so require the calculation of this indicator.

In sum, CCT makes it plausible that accounting information including corporate annual reports is potentially relevant to trade unions.

CCT is introduced in the accounting literature by Watts (1977) and Watts and Zimmerman (1986 and 1990). For a collection of articles that apply the CCT to accounting see Ball and Smith (1992, especially Part I). A more recent example of the use of the CCT in the setting of collective wage bargaining is Konings et al. (1998).

\subsection{Perspectives used in the empirical financial accounting literature on the relevance of accounting information to trade union bargainers}

\subsubsection{Introduction}

In the empirical financial accounting literature, several bargaining models are presented that make it plausible that accounting information is of potential relevance to trade unions. These include models that explain wage changes and models that forecast strikes. The models may be classified as in Figure 2.1. The models will be introduced and discussed below. ${ }^{\circ}$ Chapter 3 of this dissertation reviews the main findings of these studies. Note that the analysis below is limited to models that appeared in the empirical financial accounting literature. 
Figure 2.1: Classification of the models discussed in Chapter 2.

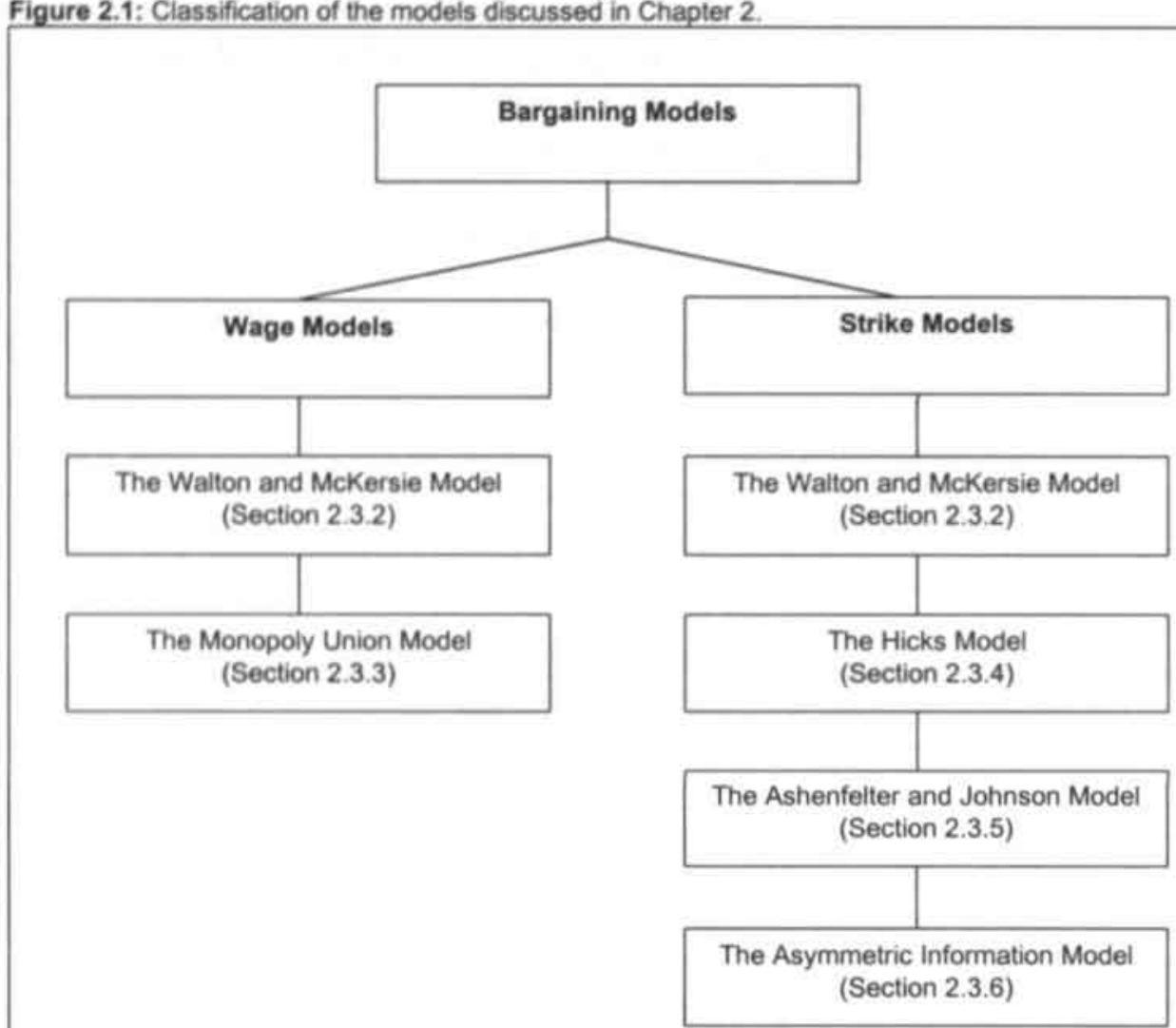

\subsubsection{The Walton and McKersie Model}

The Walton and McKersie Model (WMcKM) is behavioural model. It can be used to explain wage changes as well as strike occurrence.

In 1965, Walton and McKersie (p.4) wrote: ${ }^{10} 11$ "Labour negotiations (...) [are] comprised of four systems of activity, each with its own function for the interacting parties, its own internal logic, and its own identifiable set of instrumental acts or tactics. We shall refer to each of the distinguishable systems of activities as a subprocess. The first subprocess is distributive bargaining; its function is to resolve pure conflicts of interest. The second, integrative bargaining, functions to find common or complementary interests and solves problems confronting both parties. The third sub-process is attitudinal structuring and its functions are to influence the attitudes of the participants toward each other and to affect the basic bonds which 
relate the two parties they present. A fourth subprocess, intra-organisational bargaining, has the function of achieving consensus within each of the interacting groups."

Collective wage bargaining typically has distributive characteristics. In distributive bargaining, trade unions and management explicitly or implicitly define a best outcome or target point $\left(U_{T}\right.$ and $\left.M_{T}\right)$ and a minimum outcome or resistance point $\left(U_{R P}\right.$ and $\left.M_{R P}\right)$, as is illustrated in Figure 2.2.

Figure 2.2: An example of a positive settlement range in case of bargaining over a hourly wage increase (based on Walton and McKersie, 1965, p.43).

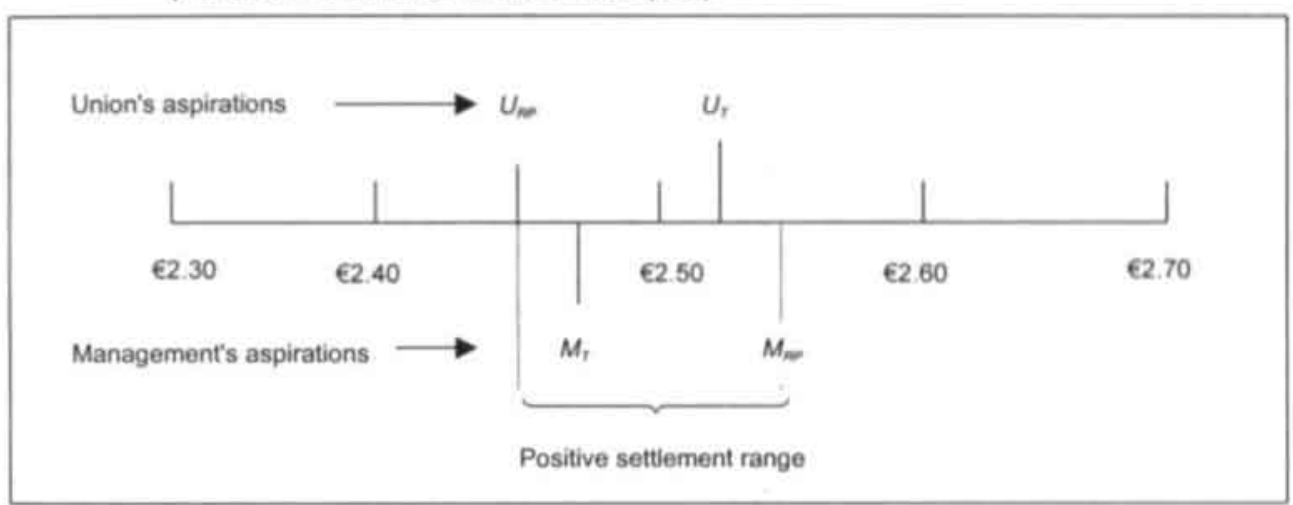

Accounting information can be used by trade unions to change the outcome of bargaining (or the possible settlement range) via (1) affecting management's perceptions of the union resistance points, or via (2) assessing and affecting the resistance point of management. In distributive bargaining, accounting information is used as a weapon to support the own case. An important tactic here, is to communicate accounting information to "obscure rather than clarify knowledge about where resistance points actually are". ${ }^{12}$ In integrative bargaining, high grade solutions will only be reached if parties have a positive attitude to exchanging accounting information. Voluntarily disclosing accounting information may be regarded as an attitudinal tactic to influence the attitudes of the opponents. Likewise, by demanding accounting information, trade unions signal their interest in the problems of management. This may add to a constructive atmosphere. In intra-organisational bargaining accounting information may be helpful in reaching consensus within the bargaining team.

Table 2,1 summarises the four subprocesses and sketches the role of information in each of these processes. Information, of course, includes accounting information. 
Table 2.1: The role of accounting information in the four subprocesses based on Tracy and Peterson (1986) and Amernic and Craig (1992).

\begin{tabular}{llll}
\hline $\begin{array}{l}\text { Subprocesses } \\
\text { Distributive } \\
\text { bargaining }\end{array}$ & Party's goals & Tactic & Dilemmas \\
\hline $\begin{array}{l}\text { Integrative } \\
\text { bargaining }\end{array}$ & Increase joint benefits & $\begin{array}{l}\text { Use information to } \\
\text { support own case; } \\
\text { withholding information; } \\
\text { disclose information to } \\
\text { obscure rather than } \\
\text { clarify }\end{array}$ & $\begin{array}{l}\text { Choosing tactics and } \\
\text { strategies }\end{array}$ \\
\hline $\begin{array}{l}\text { openty; use information } \\
\text { to explore alternatives }\end{array}$ & $\begin{array}{l}\text { Deciding whether to } \\
\text { interfere with distributive } \\
\text { tactics }\end{array}$ \\
\hline $\begin{array}{lll}\text { Attitudinal } \\
\text { structuring }\end{array}$ & $\begin{array}{l}\text { Develop a more } \\
\text { co-operative } \\
\text { relationship }\end{array}$ & $\begin{array}{l}\text { Disclose information } \\
\text { upon request; show } \\
\text { interest in other party's } \\
\text { problems by asking } \\
\text { information }\end{array}$ & $\begin{array}{l}\text { Deciding to interfere with } \\
\text { distributive tactics; } \\
\text { mitigating vulnerability to } \\
\text { exploitation }\end{array}$ \\
\hline $\begin{array}{l}\text { Intra- } \\
\text { organisational } \\
\text { bargaining }\end{array}$ & $\begin{array}{l}\text { Make principals' } \\
\text { expectations more } \\
\text { realistic }\end{array}$ & $\begin{array}{l}\text { Giving early information } \\
\text { on feasibility of } \\
\text { objectives; use } \\
\text { information to rationalise } \\
\text { viewpoints }\end{array}$ & $\begin{array}{l}\text { Deciding whether to } \\
\text { adopt active or passive } \\
\text { tactics, interference with } \\
\text { distributive need for } \\
\text { commitment, or violate } \\
\text { trust }\end{array}$ \\
\hline
\end{tabular}

Empirical financial accounting studies that used the WMcKM, its concepts and terminology to motivate that accounting information, including corporate annual reports is useful to trade unions include Foley and Maunders (1979), Amernic (1989), Amernic and Aranya (1990), Morishima (1991), and Amernic and Craig (1992).'13

\subsubsection{The Monopoly Union Model}

The Monopoly Union Model (MUM) is economics based. It is a popular approach to the wage determination process and it served as a basis for more sophisticated models. ${ }^{14}$

The MUM specifies trade unions' objectives as an increasing function of wages and employment. The objective function is written as:

$U=U(w, n)$

where $U$ is union utility, $w$ and $n$ are wages and employment respectively, and $\partial / \partial w$ $>0$ and $\partial U / \partial \hat{n}>0$. 
The MUM assumes that wages are set by trade unions given the management's labour demand curve. Once the wage is set, the management decides how many employees to hire. According to Booth (1995, p.97): "the trade union is expected to understand how the company will behave in response to the wage."

Trade unions are expected to capture part of the company's profits by negotiating a wage above the competitive level. They must make sure, however, that they will not drive the company out of business. The competitive company will react to higher wages by reducing output or substituting capital for labour. As a consequence, each union member faces some probability of being unemployed.

Two conditions have to be met before trade unions can push wages above the competitive level. There must be economic rents or surplus in the product market, and trade unions must have some power to force companies to share the surplus. The surplus itself may arise from several sources such as market imperfections or market regulations (Booth, 1995, p.53). Trade unions' power to capture economic rents results from their capacity to inflict damage on the company by mobilising employees for strike. This power varies among companies, industries and in time.

To asses the size of the economic rents and to estimate the management's reaction to the wage level set, trade unions may use accounting information indicating the business performance. Trade unions have to determine the probability that an above competitive wage level drives the company out of business. Accounting information is used for this purpose as long as alternative sources of information that indicate the size of the economic rents are more costly, less accurate or not available.

The MUM is used by Liberty and Zimmerman (1986).

\subsubsection{The Hicks Model}

The Hicks Model (HM) is also economics based. The HM assumes that the company and trade unions maximise utility. For the company this is maximising profits, for trade unions "to protect the standards of live, to maintain fair wages and to secure to the employees a share in exceptional profits" (Hicks, 1963, p.140).

The possibility of mobilising employees for strike and to impose costs on the company allows trade unions to bargain for a wage premium. Strikes, however, are not only costly to the employer but to trade unions too.

Strikes make employers loose profit and confront them with dissatisfied consumers. 
These costs are a positive function of strike duration. A rational employer is indifferent between a certain wage increase and a certain strike length if the discounted costs of the two are equal. The combinations where the discounted value of the costs associated with a certain wage increase match the discounted value of the costs associated with a strike with a certain length present the employer concession curve.

Strikes are also costly to trade unions because the company may be able to sustain a strike and force trade unions to pay a strike benefit to their members. These costs are a positive function of strike duration. For each strike of a given duration there is a wage at which rational trade unions are indifferent between the strike and the wage. The union resistance curve presents all of those combinations.

Figure 2.3 presents the two curves.

Figure 2.3: Hicks Model of wage bargaining.

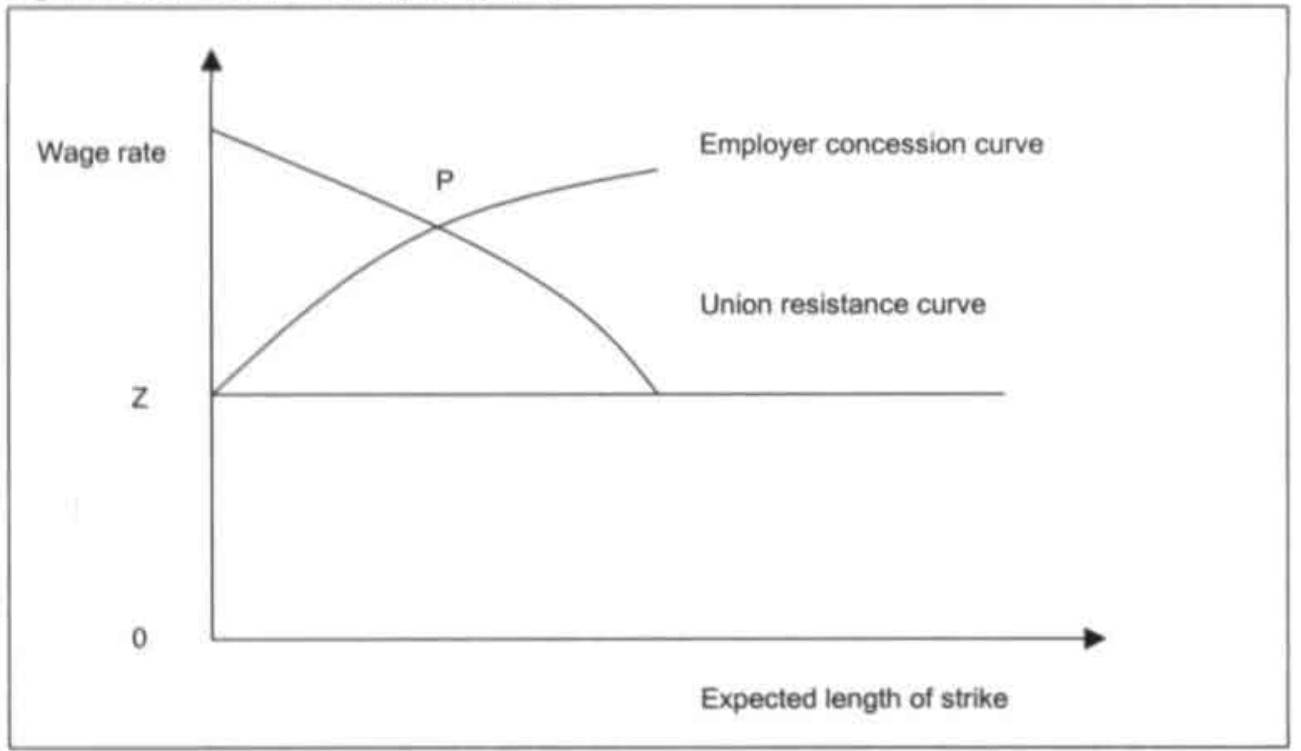

$\mathrm{Z}$ is the minimum wage below which the employer can not keep the employees. At a wage below point $Z$ the employees prefer to be unemployed rather than to work. The intersection of the curves represents an equilibrium (P). The employer and trade unions are willing to accept this wage. The slope of the employer concession curve is affected by management's tolerance for strikes. 
An important modification of the $\mathrm{HM}$ is the assumption that trade unions only have limited information on the slope and position of the employer concession curve. When trade unions overestimate the employer concession schedule, strikes become more likely. Figure 2.4 presents the actual $(E C$ and $U C$ ) and perceived but incorrect employer concession curve ( $E C$ perc $\left._{v}\right)$ and union resistance curve $\left(U C\right.$ perc $\left._{\xi}\right)$. Due to misunderstanding of the position of the other party (both parties are overly optimistic) trade unions demand $W_{U}$ whereas employers are willing to pay $W_{\mathrm{E}}$.

Figure 2.4: Strikes as a result of incorrect perceptions (Hirsch and Addison, 1986, p.86)

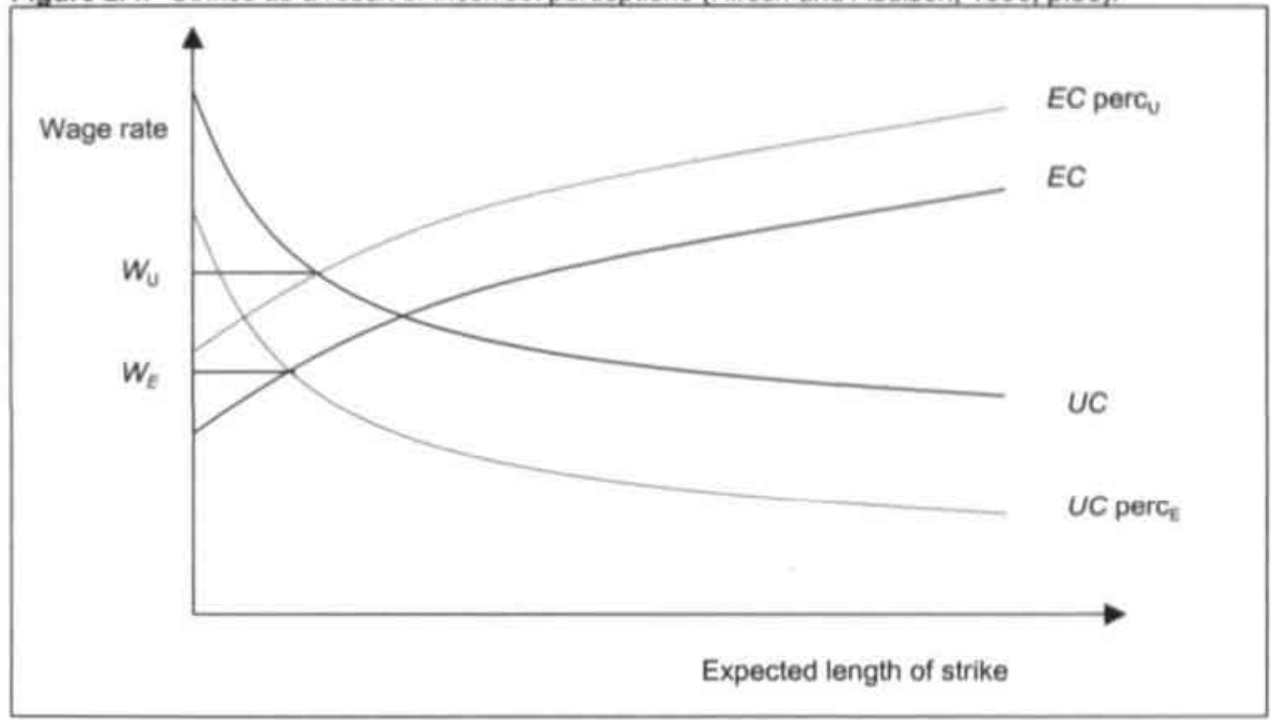

Management tolerance for strikes depends, amongst others, on unearned profits. When business is good, the cost of a strike will increase because unearned profits will be higher. Therefore, if the business outlook is good the employer has more to loose making him more willing to accept high wage claims. ${ }^{15}$

Trade unions may use accounting information to estimate the employer concession curve before the start of the bargaining process. Assuming that past profits are some forecast of current profits, trade unions may use accounting information to assess the willingness of the company to do wage concessions.

The $\mathrm{HM}$ as a theoretical approach to the usefulness of accounting information to trade unions is used by Yamaji (1986). 


\subsubsection{The Ashenfelter and Johnson Model}

This economics based model is introduced by Ashenfelter and Johnson (1969).

The Ashenfelter and Johnson Model (AJM) forecasts the likelihood of strike activity. It introduces three actors; the company, trade union leaders and trade union members. The company maximises the discounted value of the future profit stream. Trade union leaders are concerned about the survival and growth of the trade union, and about personal political survival. Although the objectives of trade union members are not defined explicitly, from the analysis it can be learned that it includes the wage level (e.g. the discounted value of the members' wages over the length of the contract).

If the members expect a wage increase much higher than what the company is willing to offer, trade union leaders have incentives to convince the members to be satisfied with a smaller increase. If the leaders are not able to get expectations down, they can either sign an agreement with a wage increase lower than expected by the members, or they can call for a strike. The first alternative weakens the political position of the leaders. The second alternative does not serve the interest of the union members. The strike lowers members' expectations and they have to incur the cost of lost wage income. After a while, expectations are low enough to sign a contract that is acceptable to the members and the strike ends.

If the company agrees to the wage increase that is acceptable to union members at contract expiration, the strike is avoided. The company therefore has to weight the effect of a higher wage and the effect of a strike on the discounted value of the future profit stream.

Ashenfelter and Johnson start with the following model (p.40):

$S_{t}^{\prime}=\beta_{0}+\beta_{1} T+\beta_{2} y_{0}+\beta_{3} \pi^{*} t_{1}$

where $S_{t}^{\prime}$ is the probability of a strike in period $t, \mathrm{~T}$ indexes the passage of time, $y_{0}$ is the acceptable wage increase to trade union members at the point of contract expiration and $\pi^{*}$ is the ratio of the preagreement profit level to the wage bill. The expectation was that $\beta_{2}>0, \beta_{3}<0$ and $\beta_{0}>0$, since some strikes take place for institutional reasons, and $\beta_{1}<0$ since the number of strikes had been steadily declining in the $1950 \mathrm{~s}$ and $1960 \mathrm{~s}$.

The acceptable wage increase to trade union members at the point of contract expiration $\left(y_{0}\right)$ is defined as (p.41): 


$$
y_{0 t}=\alpha_{1}+\alpha_{2} \sum_{i=0}^{M} \mu_{i} \Delta R_{t-i}+\alpha_{3} u_{t}+\alpha_{4} \pi_{t-1}^{*}
$$

where the second term is a moving average of previous changes in real wages, $u_{t}$ is the unemployment rate, and again $\pi^{*}$ is the ratio of the preagreement profit level to the wage bill, and $\alpha_{1}>0, \alpha_{3}<0, \alpha_{4}>0$ and $\alpha_{2}<0$. The latter suggest that when real wages have been increasing rapidly, $\mathrm{y}_{0}$ is low. Note that $\alpha_{4}>0$. According to Ashenfelter and Johnson (p.41) "if the firm's profit level has been high in recent periods, the typical union member may feel that he deserves a larger wage increase (...) also the motivation of the leadership to attempt the task of persuading the membership to be content with a lower settlement will be diminished".

Substituting (2) in (1), generates:

$\mathrm{S}_{t}=A+B_{1} \sum_{i=0}^{M} \mu_{i} \Delta R_{t_{4}}+B_{2} \mathrm{u}_{t}+B_{3} \pi_{t_{4}}^{*}+B_{4} T+\varepsilon_{t}$

where $\varepsilon_{t}$ is the disturbance term and $A>0, B_{1} \mu_{i}<0, B_{2}<0$, and $B_{4}<0$. Since $B_{3}=\beta_{2} \alpha_{4}+$ $\beta_{3}$, and $\beta_{2} \alpha_{4}>0, \beta_{3}<0$, the sign on profits in equation (3) is indeterminant. According to Ashenfelter and Johnson (p.41) "although management is more likely to give in when previous profits are high, the union is also likely to increase its demands. Hence, it is not clear whether the net effect of an increase in profits will be to increase, decrease, or have no appreciable effect on the probability of occurrence of a strike".

In fact, the AJM assumes a positive relationship between the profitability of the company and trade unions' wage demands. For this reason, accounting information is likely to be of relevance to trade unions.

In the accounting literature the AJM is used by Liberty and Zimmerman (1986).

\subsubsection{The Asymmetric Information Model}

Also the Asymmetric Information Model (AIM) is economics based. It is developed in Hayes (1984), Tracy (1987) and Abowd and Tracy (1989).

In the AIM, trade unions' objectives are some combination of wages, employment and strike length, while the company is believed to maximise profits. Each side lacks 
information about the exact function the other side is maximising.

Collective wage bargaining is the dominating process by which rents accruing to the company are allocated between the employees and other stakeholders. The higher the relative power of trade unions, the more successful they will be in capturing the economic rents. Power results from the capacity to inflict damage on the company by withdrawing employees from labour. At first side, strikes seem irrational or inefficient since both parties are better of if the post-strike settlement is agreed upon immediately (Hayes, 1984, p.57; Booth, 1995, p.141). The AIM introduces incomplete or asymmetric information, which rationalises strike activity. In the AIM, the company has superior information about the future profitability, both in terms of the expected size of profits and in terms of the degree of uncertainty about profits. ${ }^{16}$ Collective wage bargaining then serves as a learning process by which trade unions derive private corporate information by observing the schedule of wage offers proposed by management during the talks.

Trade unions can offer to work at a high wages immediately, or to work at a lower wage after a strike of a certain length. The company has an incentive to accept the high wage if business outlooks are good and to bargain for a low wage if the outlooks are bad. The ability to pay is a function of the company's possibilities to pass on labour costs and to cut production costs. ${ }^{17}$ Trade unions lack direct information about the company's ability to pay.

The schedule of wage offers depends on the probability that a certain scenario (good, bad) occurs. As the probability increases that a given scenario occurs, the schedule of wage offers will change to reflect this information. Trade unions may use the threat of strikes to put pressure on the company to bring wage offers, thereby signalling perceptions on business outlooks.

Trade unions are likely to prefer alternative proxies of ability to pay which are available at low costs, such as accounting information in corporate annual reports, over deriving the ability to pay via bargaining rounds with a possibility that strikes will occur. The latter scenario would be more costly to trade unions.

The AIM is used by Morishima (1991).

\section{$2.4 \quad$ A synthesis}

Central in this chapter are theoretical approaches on the relevance of accounting information in corporate annual reports, to trade unions in the context of collective 
wage bargaining. This analysis is limited to the theories presented in the empirical financial accounting literature. The aim is to make it plausible that accounting information is of potential relevance to trade unions in this context. It is not our intention to select the approach that best describes the Dutch setting. ${ }^{.8}$

Table 2.2 summarises the potential relevance of accounting information in the models discussed.

Table 2.2: The potential relevance of accounting information in the models discussed.

\begin{tabular}{lll}
\hline Theory / model & Key element \\
\hline Contracting Cost & Stakeholders are self- \\
Theory & interested. Companies can only \\
& survive if contracts are efficient.
\end{tabular}

\begin{aligned} \hline The Walton and & Bargaining consist of four \\ McKersie Model & $\begin{array}{l}\text { subprocesses: distributive } \\ \text { bargaining, integrative } \\ \text { bargaining, attitudinal } \\ \text { structuring and intra- } \\ \text { organisational bargaining. }\end{array}\end{aligned}$

The Monopoly Unions set the wage level and Union Model the company decides how many employees to hire at that wage. The latter depends, for instance, on the product demand curve. The potential role of accounting information

Unions may use accounting information in contractual decision making and as a monitoring device in the case of employee profit sharing plans.

Unions use accounting information strategically and tactically. In distributive bargaining. accounting information may be used to support the own case, to affect management's perceptions of the union's resistance points and to determine the resistance points of management.

Unions may use accounting information indicating the business performance to asses the size of the economic rents. It may also be used for assessing the product demand curve of the company and to estimate its reaction to the wage level demanded.

\begin{tabular}{|c|c|}
\hline The Hicks Model & $\begin{array}{l}\text { Wage increases results from } \\
\text { management (employer } \\
\text { concession curve) and union } \\
\text { strike aversion (union } \\
\text { resistance curve). Management } \\
\text { strike aversion is higher when } \\
\text { business outlooks are good. }\end{array}$ \\
\hline
\end{tabular}

The Ashenfelter Strike probability is related to and Johnson the profits reported by the Model

Unions may use accounting information to determine the business outlook, thereby assessing management strike aversion (employer concession curve).
Union demands are positively related to the performance of the company. Unions may use accounting information to assess the performance of the company. company. The direction of the impact is unclear: the company is more likely to give in when previous profits are high and the union is likely to increase its demands.

The Asymmetric Unions face an information Information asymmetry. The company has Model superior information about the future profitability. Collective wage bargaining serves as a learning process by which the union derives private corporate information by observing the schedule of wage offers proposed by the company.

Unions derive private corporate information on management's perceptions of the business outlook to determine the company's ability to pay. Accounting information may be used to limit information asymmetry because the information can be obtained at low cost. 
From the models as in Section 2.2 and 2.3 it can be learned that both economics based contracting cost theory and theories used in empirical financial accounting research make it plausible that accounting information is potentially relevant to trade unions in collective wage bargaining. Although presented in various forms, the basic idea is that accounting information indicates the position and performance of the company, the ability to pay and the company's willingness to do wage concessions. We hypothesise that trade union bargainers potentially use accounting information for three reasons: for the purpose of general orientation, for making wage claim decisions and for a contracting purpose.

As noted, the demand of accounting information by trade unions, however, is not beyond dispute. Bougen and Ogden (1981), Amernic (1985) and Ogden and Bougen (1985) follow a more radical approach to management-union bargaining. Tinker (1980) and Ogden and Bougen (1985) see accounting information as an instrument of social domination. On management's motivations for disclosing accounting intormation Ugden and Bougen (1985, p.211) argue:

"accounting information may be used as a means of socialising trade unions into endorsing the primacy of market criteria for management decision-making. Disclosure, therefore, could serve the dual purpose of both simultaneously informing and manipulating trade unions".

On the consequences of this for trade unions' demand of accounting information, they continue as follows (Ogden and Bougen, 1985 p.211):

"The extent to which accounting information entails an ideological basis in favour of management raises questions for unions as to its potential utility. On the one hand securing systematic disclosure of accounting information has advantages for unions. It would reduce the comparative advantage management enjoys in negotiations being the sole possessor of information (...) On the other hand, however, by using accounting information disclosed by management, unions would become exposed to the latent ideological conditioning such information entails."

So, we expect that accounting information is potentially relevant to trade union bargainers, whether this information is indeed used in the setting of collective wage bargaining is an empirical issue. ${ }^{19}$ That issue will be addressed in various forms in Chapter 4 and 5 of this dissertation.

\subsection{The potential relevance of auditing to trade union bargainers}

So far, the focus was on the potential relevance of accounting information to trade 
unions. Now we will turn to the potential relevance of auditing to trade unions.

We hypothesise that auditing is potentially relevant to trade unions in two respects; auditing may add reliability to accounting information prepared and disclosed by management, and auditing may be relevant for verifying specific contractual arrangements, for instance employee profit sharing plans. Such plans can only reduce agency costs if trade unions can determine whether the contract has been breached. Like in other contractual settings, auditors may play this role.

Similar to the relevance of accounting information to trade unions, also trade unions' perceptions of auditing and auditors is an issue that requires empirical attention. This topic will be addressed in Chapter 6 and 7 of this dissertation.

\subsection{Conclusions}

Our maintained hypothesis in Chapter 4 to 7 of this dissertation is that trade unions in the context of collective wage bargaining will perceive accounting information in corporate annual reports and the auditing of this information as useful.

The structure of collective wage bargaining in the Netherlands (see Chapter 1 and Appendix $\mathrm{B}$ at the end of this dissertation) allows a strengthening of the maintained hypothesis. We expect that trade union bargainers who bargain at corporate-level will perceive corporate specific accounting information in corporate annual reports and the audit of this information to be more useful than trade union bargainers who bargain at industry-level, ceteris paribus. 


\section{Notes}

1. The author wishes to thank Erik de Regt for useful comments on an earlier version of this chapter.

2. In the contracting cost theory or property rights theory the focus is on rights based on contracts. This theory is rooted in Coase (1937) and extended by Jensen and Meckling (1976) and Fama and Jensen (1983a and 1983b).

3. The nexus of contracts concept is introduced by Jensen and Meckling (1976).

4. For a definition and an analysis of the nature of agency problems see Fama and Jensen (1983b, p.327). For a collection of agency aspects and problems in an accounting setting, see Bamberg and Spremann (eds.) (1987).

5. A collective bargaining contract is a written contract between (one or more) employers and employees that covers the rights and obligations of a group of employees for a given period. For two exampies of collective bargaining contracts see Appendix $\mathrm{C}$ at the end of this dissertation

6. Employee profit sharing plans typically specify the relation between a company's reported profit and the bonus reward for non-executive employees.

7. We are aware of one contribution to the accounting literature that derives the employee objective function. Maunders (1984) argued that employees are likely to be interested in expected returns (salary, non-financial rewards and career opportunities) and risk attached to expected return (job security). If expected return and risk are relevant to employees, and because trade unions face competition (employees can switch or terminate trade union membership), expected return and risk as faced by employees are likely to be relevant to trade union bargainers as their agents as well. Future returns for employees and the variability of those returns correlate with future operating cash flows of the company and the variability of those cash flows. So, to assess return and risk, future operating cash flows must be estimated.

8. Assuming that trade unions need information on the performance of the company an interesting issue is whether trade unions need information on the past performance or on the future performance of the company. With regard to the use of accounting information this difference is not relevant. Future cash flows can not be observed and historical based accounting numbers provide an alternative.

9. For a review of the theoretical role of accounting information in a number of models of collective wage bargaining that, to our knowledge, not have been used in empirical financial accounting research see Foley and Maunders (1979, chapter 4). Also, again, note that our intention in this chapter is not to give a complete overview of all collective wage bargaining models or strike models that make the use of accounting information 
by trade unions plausible. We restrict ourselves to the models already used in the empirical financial accounting literature in this area.

10. See also Foley and Maunders (1979) and Amernic and Aranya (1990). For discussions of the Walton and McKersie Model in the labour economics literature see Kochan (1980, p.243), Chamberlain and Kuhn (1986, p.173) and Tracy and Peterson (1986).

11. See for instance Amernic (1985, p.232).

12. See Foley and Maunders (1979, p.104).

13. This model is discussed by Foley and Maunders (1979), Ogden and Bougen (1981) and Amernic (1985).

14. For instance the Right-to-Management Model and the Median Voter Model (Booth, 1995, p.108).

15. According to Yamaji (1986, p.14): "Management easily accepts wage increases during a prosperous business cycle but resist them during depressed business time. Management's forecast of the business cycle is a factor crucial to the labor union when the latter estimates the shape of the employer concession curve. Management can then forecast future business conditions partly by using accounting information disclosed in the past. Similarly, the labor union forecasts these conditions based on the same accounting information, macroeconomic data, and other miscellaneous sources".

16. Executive management is typically better informed about issues like R\&D and new clients than trade unions are. Information on variables that increase the expected size of profits is likely to decrease strike activity (less likely that a strike will occur and the shorter its expected duration) and increase wage settlements (Abowd and Tracy, 1989, p.232). Variables that increase with the degree of uncertainty about future profits are likely to increase the strike activity and to increase wage settlements.

17. The extent to which wage increases can be shifted to other stakeholders (e.g. to consumers via higher prices, to shareholders via lower profits) depends, amongst others, on the level of concentration in the industry. For more see Abowd and Tracy (1989, p.230).

18. For analyses of the suitability of bargaining theories for describing the Dutch bargaining setting see for instance Lever (1993), Wijngaert (1994, pp.71-72), Van den Toren (1996) and Rojer (1996).

19. Our expectation is supported because of involvement of Dutch trade unions with the Dutch Enterprise Chamber, where interested parties may file a charge of failure to comply with financial accounting law and demanded restatement of the CAR. Trade 
unions filed such a complaint twice, indicating that accounting information is relevant. For a more extensive analysis, see Appendix D of this dissertation. 


\section{Chapter 3 \\ An Overview of Previous Research and Four Research Opportunities}

\subsection{Introduction}

This chapter has three objectives: (1) to discuss empirical studies on the interface of accounting, auditing and collective wage bargaining (Section 3.2), (2) to evaluate the findings of these studies (Section 3.3), and (3) to identify gaps in the research that offer opportunities for this dissertation to focus on (Section 3.4).

3.2 Empirical research in accounting, auditing and collective wage bargaining

\subsubsection{Introduction}

Empirical research on accounting, auditing and collective wage bargaining can be classified in different ways. This chapter employs the following classifications:

1. Empirical studies on the usefulness of accounting information by trade unions (Section 3.2.2).

2. Empirical studies on the impact of accounting information on the process and outcome of collective wage bargaining (Section 3.2.3).

3. Empirical studies on the effect of collective wage bargaining on the process of financial accounting (Section 3.2.4).

4. Empirical studies on the perceptions of trade unions on independent auditors (Section 3.2.5).

The focus of this chapter is on empirical work published from 1970 to 2000 . $^{\prime}$ This chronological overview includes field studies, archival studies and experiments published in the accounting and auditing literature. ${ }^{2}$ Since the relation between companies and individual employees is beyond the scope of this dissertation, those lines of research will not be discussed. ${ }^{3}$ 


\subsubsection{Empirical studies on the usefulness of accounting information to trade unions}

Empirical research on the usefulness of accounting information to trade unions include Cooper and Essex (1977), Palmer (1977), Foley and Maunders (1979), Ward (1987), Mautz (1990), Clarke and Craig (1992), and McBarnet et al. (1993).

Cooper and Essex (1977) explored the information needs of UK shop stewards. They focused first on the decisions shop stewards have to take in order to satisfy their objectives, and then they derived the information needs resulting from the objectives. They surveyed 230 shop stewards. The most important objectives shop stewards had concerned basic pay, safety and health. Cooper and Essex concluded that as far as basic pay is concerned, the shop stewards' information needs include information on ability to pay. They also investigated the nature of the shop stewards' information sources directly, by asking them what information they use in bargaining. Information obtained from the trade union ranked first, while information from other shop stewards and published financial statements ranked second and third, respectively. Finally, when looking at the importance of justifying factors in wage claims, profits made by the company ranked third, behind cost of living and comparison with others in the same workplace.

Palmer (1977) asked US industrial relation managers to indicate the amount and type of accounting information requested by trade union bargainers. According to 27 of the 80 respondents $(34 \%)$, little or no data were requested by the unions, while 48 respondents $(60 \%)$ indicated that the data usually requested include the bargaining unit's profitability. Palmer also examined US trade unions' access to and use of accounting information directly. He concluded that, although most trade union bargainers believe that they have reasonable to good access to accounting information, they are critical of its usefulness and reliability. Trade unions appeared to prefer accounting information that is independently audited and that is provided on an ongoing basis, in years of high and years of low profitability. Furthermore, trade unions want less conservative and more accurate information for bargaining purposes. A large majority of the trade union bargainers said that more information would enable them to negotiate more successfully. Palmer also studied the impact of the disclosure of accounting information on the demands of trade union bargainers. $\mathrm{He}$ asked to what extent trade unions bargainers alter their bargaining position or soften their demands if accounting information indicates a company's inability or limited ability to pay. The results were mixed; one quarter of the respondents answered that they had often altered their bargaining position when a company appeared to be in difficulty, another quarter said they had never done so, while half of the respondents 
indicated that they had, but only because of special circumstances. Finally, Palmer concluded that increased data disclosure leads to a more co-operative trade union attitude in bargaining.

Foley and Maunders (1979, p.131) examined 102 research documents to investigate the role of accounting information in company analysis. ${ }^{4}$ The documents were prepared by the research staff of two UK trade unions. All the accounting information used in the documents appeared to be obtainable from corporate annual reports. The authors had two possible explanations for this; it was used either because it was available and relevant, or because trade unions were conditioned to use it. 5 Additional talks with research staff members made clear that corporate annual reports were a major source of information in preparing these documents. The financial accounting indicators most often quoted were turnover, trading profits, dividends, profit before tax, and capital employed. The use of profit indicators is explained by the tactical dimension of this information. Foley and Maunders (1979, p.134) concluded that "the major sources of financial information to trade unions are published company reports and government publications (for industry-wide data)".

Ward (1987) examined the use and usefulness of governmental annual reports as perceived by public sector trade unions. The starting point was the notion that teacher unions had become concerned about receiving reliable and itemised figures on the performance of local school districts for the purpose of collective wage bargaining. Ward surveyed the presidents of 50 local unions affiliated with the American Federation of Teachers. The results indicated that the adopted budget and annual reports were the major sources used in trade union analysis. The annual reports were generally easy to obtain. Three quarters of the respondents indicated that they use information from the school districts' annual reports in collective wage bargaining. One quarter of the respondents don't use these reports because they were not able to interpret the data. The three most important kinds of analytical data were examination of expenditures by category, actual balances and reserves, and the comparison of budget and actual data. The local trade unions' unfulfilled information needs include detailed data on staffing, reports on a monthly basis, and data on fund transfers. According to three quarters of the respondents, ability to pay was a very important argument for justifying wage claims.

Mautz (1990) explored the usefulness of inflation-adjusted accounting disclosures to trade unions in collective wage bargaining. He studied the reactions of research directors and other officials of US and Canadian trade unions to inflation-adjusted information in assessing a company's ability to pay wages. He also looked into the impact of the company's financial performance and financial position on trade union 
wage claims. All 59 respondents (response rate $21.4 \%$ ) received the historical based corporate annual report of three (fictitious) companies. One half of the respondents also received data adjusted for inflation. The financial performance and position differed substantially among the three companies: one company had a typically strong financial position, one a moderate position, and one a weak position. The results showed that ability to pay was perceived to be higher for the strong company than for the moderate and the weak company, and also perceived to be higher for the moderate than for the weak company. Furthermore, the ability to pay as perceived by the respondents who also received the inflation-adjusted data did not differ significantly from that of the respondents who had only the historical based figures. Hence, there is no evidence that trade unions lower their wage claims if current costs-based statements are supplied. Mautz also investigated the confidence respondents had in their assessment of the company's ability to pay. As hypothesised, the confidence of the respondents who conducted the analysis of the stronger company was higher than that of respondents who did the same for the two weaker companies. This was true for both the "current costs disclosure-case" and the "non-disclosure case". The analysis suggested that inflation-adjusted disclosures were not useful to trade unions because, in contradiction to what was hypothesised, the respondents who received inflation-adjusted data were less confident in their estimation of the companies' ability to pay than the subjects who received only historical costs-based data.

Clarke and Craig (1992) investigated the understanding of Australian industrial relations practitioners, including trade union officials, of accounting information in collective wage bargaining, and the problems attached to this information. The questionnaire was returned by 201 respondents, including 74 trade union officials and research officers. The respondents were asked to indicate what type of information they think should be used to assess a company's ability to pay wages. Of the trade union respondents, $64 \%$ indicated that the income statement should be used, $57 \%$ indicated the same for the balance sheet, and $47 \%$ for cash flow forecasts. Clarke and Craig also found that of all industrial relations practitioners in their study, "unions were the most sceptical about the usefulness, importance and relevance of accounting data and were most strongly of the opinion that none of the suggested accounting data should be used in assessing an enterprise's capacity to pay". They also studied trade unions' actual use of accounting information in assessing the ability to pay wages. According to the union respondents, the three most important types of accounting data in assessing ability to pay were (1) the profit trend of the past few years, (2) projected costs and revenues, and (3) the most recently reported profit level.

McBarnet et al. (1993) interviewed UK senior trade union officials, research officers and trade union bargainers on the use of accounting information in collective wage 
bargaining. The authors also observed trade union participants during a course on financial accounting and analysis. Subsequently, they conducted interviews with the attendees. They found that accounting information was used by trade unions on a routine basis and for many objectives, including wage bargaining, bargaining in the setting of planned mergers, closure or redundancy proposals, health and safety conditions and profit-based bonus rewards. One trade union headquarters received 35 to 40 requests a week from local trade unions to perform financial statement analysis.

Table 3.1 summarises the main findings of the studies discussed above.

Table 3.1: Summary of studies on the usefulness of accounting information to trade unions.

\begin{tabular}{ll}
\hline Authors & Context \\
\hline $\begin{array}{l}\text { Esoper and } \\
\text { Essex (1977) }\end{array}$ & $\begin{array}{l}\text { The bargaining objectives } \\
\text { and information needs of } \\
230 \text { UK shop stewards. }\end{array}$ \\
\hline Palmer (1977) & $\begin{array}{l}\text { Type of information } \\
\text { requested by US trade } \\
\text { unions in collective wage } \\
\text { bargaining. }\end{array}$
\end{tabular}
Main findings

The main concerns in bargaining are basic pay, safety questions, and health questions. Corporate annual reports are a major source of information. Profit is an important justifying factor in making wage claims.

Data usually requested by trade unions include profitability. Relevance and reliability of financial accounting information are criticised. More information enables bargainers to bargain more successfully. Half of respondents had altered their demands because of the company's limited ability to pay.

\begin{tabular}{lll}
\hline Foley and & Examination of 102 & Corporate annual reports were a major source of \\
Maunders & documents prepared by information for preparing the documents.
\end{tabular}

(1979) two UK trade unions.

Ward (1987) Use and usefulness of $75 \%$ of the respondents indicated the use of information governmental annual from the school districts' annual reports. Most important reports as perceived by were examination of expenditures by category, actual US public sector trade balances and reserves, and comparison of budget and unions. actual data. Unfulfilled information needs include detailed data on staffing, data on fund transfers and reports on a monthly basis. Ability to pay was a very important argument in making a wage claim.

Mautz (1990) Usefulness of inflationadjusted disclosures to US and Canadian trade unions.

No evidence that trade unions lower their wage claims if current costs-based reports are supplied. Respondents who received inflation-adjusted data were less confident of their estimation of the ability to pay than those who received only historical costs-based data.

\begin{tabular}{ll}
\hline Clarke and & $\begin{array}{l}\text { Exploration of Australian } \\
\text { Craig (1992) } \\
\text { unde union officials' } \\
\text { understanding of } \\
\text { accounting information. }\end{array}$
\end{tabular}

Information obtained from the income statement, profit trend and projected costs and revenues is important in assessing capacity to pay wages. Most important were (1) the profit trend of the past few years, (2) projected costs and revenues, and (3) the most recent reported profit level.

\begin{tabular}{lll}
\hline $\begin{array}{l}\text { McBarnet et al. Exploration of UK trade } \\
\text { (1993) }\end{array}$ & $\begin{array}{l}\text { Accounting information is used on a routine basis and for } \\
\text { union officials' use of } \\
\text { accounting information in objectives, including wage bargaining, bargaining in } \\
\text { bargaining. }\end{array}$ & $\begin{array}{l}\text { many setting of mergers, closure or redundancy proposais, } \\
\text { the sealth and safety conditions and profit-based bonus } \\
\text { hewards. }\end{array}$ \\
\hline
\end{tabular}




\subsubsection{Empirical studies on the impact of accounting information on the process and outcome of collective wage bargaining}

The impact of accounting information on the process and outcome of collective wage bargaining is studied by Amernic (1985), Amernic and Aranya (1990), Bougen et al. (1990), Elias (1990), Chalos et al. (1991), Morishima (1991), and Amernic and Craig (1992).

Amernic (1985) conducted a field study to explore the roles of accounting information in collective wage bargaining in the not-for-profit setting. He participated on the bargaining team of a large Canadian university as one of the bargainers on the employee side. The study is based on these bargaining experiences. Amernic used the Walton and McKersie Model to document the use of accounting information in this setting. He showed that in this particular not-for-profit setting, accounting information was used for distributive, integrative and attitudinal structuring purposes. ${ }^{6} \mathrm{He}$ concludes with a number of tentative hypothesis based on his experience, including: (1) if management discloses financial information in a timely manner, the bargaining parties behave more co-operatively, (2) a trade union's unreasonable demands may harm the employer-employee relationship, (3) the nature of the bargaining relationship may influence responses towards supply and demand of accounting information, (4) union bargainers usually face an information asymmetry, and as a result they tend to avoid accounting (based) issues, (5) the estimation of ability to pay is rather diffused in a not-for-profit setting, (6) parties interpret this information differently and use it as "ammunition in bargaining".

Amernic and Aranya (1990) designed a not-for-profit experiment to assess the impact of the disclosure of accounting information on bargaining productivity. The authors developed a questionnaire with 16 cases. The 48 respondents were all Canadian industrial relations practitioners who graduated from the Masters in Industrial Relations program at a major university. The results indicated that accounting information has the potential to influence the outcome of not-for-profit bargaining by helping to reach a fair settlement. Even in the case of an adverse bargaining environment, the disclosure of accounting information was seen as meaningful by both parties, because it allows the parties to "keep on talking".

Bougen et al. (1990) used archival data to explore the roles of accounting in collective wage bargaining. The focus was on the development of the role and importance of accounting information in time, and on the resistance to it. They studied the collective wage bargaining process in the British coal industry in the period 1875-1919. The role of accounting information changed during this period. In 
1875-1876 parties used accounting (information) in bargaining to explore possibilities and to find mutually acceptable solutions, while in 1919 the miners simply rejected the relevance of this information. The authors concluded that accounting information had the capacity to appear and to disappear in collective wage bargaining, since periods in which accounting information was injected in bargaining were alternated with periods in which it was not considered. Furthermore, the accuracy of accounting numbers was "clearly not at stake", suggesting that trade unions did not question the technical content (reliability) of this information, but merely its relevance.

Elias (1990) designed an experiment to examine the impact of the disclosure of accounting information on bargaining outcomes and the resolution of managementunion disputes. Eighty Canadian subjects (representing 40 management-union negotiating pairs) participated in the experiment. The disclosure variable concerned disclosing or withholding from trade union officials historical costs-based accounting numbers and financial projections. Data were gathered by pre-negotiation and postnegotiation questionnaires. The results indicated that disclosure or a lack of disclosure did not significantly effect the bargaining outcome. Furthermore, bargaining outcomes of firms with profit tended to be higher than outcomes of companies that reported losses.

Chalos et al. (1991) developed an experiment simulating collective wage bargaining. The experiment involved 250 participants. That case made use of real bargaining data, including revenues and expenditures, reserves, budgetary data and trends. The authors conducted three information manipulations. The first version of the case included all budgeted and actual historical revenues for the five years preceding the talks. The budgetary data indicated a forecast error; actual earnings were underestimated. The second version of the case made random forecast errors and in the third version no budgetary forecasts were disclosed. The subjects were divided into six groups (a management team and a union team for each of the three information manipulation cases) and they were asked to negotiate the most favourable contract. Salary and working hours were two items the subjects had to negotiate. In all three information conditions, the subjects were asked to rank the preferred outcomes of a set of 13 possible outcomes. One hypothesis was that information disclosure has a significant effect on union and management utilities and settlement outcomes across contract attributes (like salary and wages). The results did not confirm this. They also tested the hypothesis that information disclosure affects integrative bargaining outcomes. The results were marginally significant, suggesting that increased information sharing tends to have a positive impact on integrative bargaining outcomes.

Morishima (1991) studied the effects of the company sharing information with trade 
unions on the process and outcomes of collective wage bargaining. He surveyed 97 Japanese bargaining pairs, consisting of employers and trade unions. The results suggested that both parties gain by sharing information in collective wage bargaining, since this shortens wage talks and makes bargaining less difficult. On the other hand, shorter and less difficult talks seemed to decrease the unions' possibility for high wage claims, because management uses information to convince trade unions to accept lower wage increases. As a result, increased information sharing on the part of management seemed to be positively associated with lower union militancy.

Amernic and Craig (1992) investigated four Canadian collective wage bargaining cases to study the role of accounting information in collective wage bargaining in a not-for-profit setting. Four different cases were prepared to test the impact of employer equivocality and union heterogeneity as determinants of the role of accounting information in collective wage bargaining. Employer equivocality is the "degree to which a particular collective wage bargaining in a not-for-profit environment is characterised by diffusion, and unclear, ill-defined, muddled and confused lines of responsibility and authority". ' Union heterogeneity reflects that trade union are not homogeneous organisations, but coalitions with their own internal conflicts." The authors gathered data on these four bargaining cases via participant observation, in-depth interviews, short interviews and archival analysis. The analyses revealed that both the level of shared goals of the union (union heterogeneity) and the level of direction within the employing organisation (employer equivocality) determine the role of accounting information in collective wage bargaining in a notfor-profit setting. Accounting is most useful in not-for-profit bargaining where union heterogeneity is high (low level of shared goals) and where employer equivocality is low (the employing organisation has clear, well-defined lines of responsibility and authority).

Table 3.2 summarises the main findings of the studies discussed in this section. 
Table 3.2: Summary of studies on the impact of accounting information on the process and outcome of collective wage bargaining.

\begin{tabular}{|c|c|}
\hline Authors & Context \\
\hline Amernic (1985) & $\begin{array}{l}\text { Exploration of the roles of } \\
\text { accounting in collective } \\
\text { wage bargaining in a } \\
\text { Canadian not-for-profit } \\
\text { setting. }\end{array}$ \\
\hline
\end{tabular}

\section{Main findings}

Accounting information is used for distributive. integrative, attitudinal structuring purposes. The hypotheses included (1) if accounting information is disclosed in a timely manner, parties behave more cooperatively, (2) a trade union's unreasonable demands may harm the employer-employee relationship. (3) the nature of the bargaining relationship may influence responses towards supply and demand of accounting information (4) union bargainers attempt to avoid accounting (based) issues. (5) the estimation of ability to pay is rather diffused in a not-for-profit setting (6) information is used as "ammunition".

\begin{tabular}{|c|c|}
\hline $\begin{array}{l}\text { Amernic and } \\
\text { Aranya (1990) }\end{array}$ & $\begin{array}{l}\text { Impact of the disclosure of } \\
\text { accounting information on } \\
\text { bargaining productivity. }\end{array}$ \\
\hline
\end{tabular}

Accounting information may influence not-for-profit bargaining outcomes by helping to reach a fair settlement. In an adverse bargaining setting. disclosure allows parties to keep on talking.

\begin{tabular}{lll}
\hline $\begin{array}{l}\text { Bougen et al. } \\
\text { (1990) }\end{array}$ & $\begin{array}{l}\text { Development and success } \\
\text { of accounting information } \\
\text { and the resistance to it in } \\
\text { the UK coal industry in } \\
1875-1919 .\end{array}$ & $\begin{array}{l}\text { Accounting information has the capacity to appear and } \\
\text { to disappear in collective wage bargaining. Periods in } \\
\text { which accounting information was used by miners were } \\
\text { alternated with periods in which the relevance as a } \\
\text { justification for making decisions was rejected. }\end{array}$ \\
\hline $\begin{array}{lll}\text { Elias } \\
\text { (1990) }\end{array}$ & $\begin{array}{l}\text { Impact of the disclosure of } \\
\text { accounting information on } \\
\text { bargaining outcomes and } \\
\text { the resolution of disputes. }\end{array}$ & $\begin{array}{l}\text { Information symmetry (disclosure) did not lead to higher } \\
\text { wage claims or lower post-negotiation conflicts. } \\
\text { Bargaining outcomes tended to be higher in the profit } \\
\text { case compared to the loss case. }\end{array}$ \\
\hline $\begin{array}{ll}\text { Chalos et al. } \\
\text { (1991) }\end{array}$ & $\begin{array}{l}\text { Impact of disclosure on } \\
\text { utilities and bargaining } \\
\text { outcomes. }\end{array}$ & $\begin{array}{l}\text { No impact of disclosure on union and management } \\
\text { utilities and settlement outcomes. Increased information } \\
\text { sharing may have a positive impact on integrative } \\
\text { bargaining outcomes. }\end{array}$ \\
\hline $\begin{array}{l}\text { Morishima } \\
\text { (1991) }\end{array}$ & $\begin{array}{l}\text { Effects of disclosure on } \\
\text { process and outcomes of } \\
\text { bargaining. }\end{array}$ & $\begin{array}{l}\text { Parties gain by sharing information. Disclosure may } \\
\text { shorten wage talks and make bargaining less difficult. } \\
\text { Disclosure seemed to decrease the possibility for high } \\
\text { wage claims and to decrease union militancy. }\end{array}$ \\
\hline $\begin{array}{l}\text { Amernic and } \\
\text { Craig (1992) }\end{array}$ & $\begin{array}{l}\text { Employer equivocality and } \\
\text { union heterogeneity as } \\
\text { determinants of the role of } \\
\text { accounting information in } \\
\text { bargaining in a Canadian } \\
\text { not-for-profit setting. }\end{array}$ & $\begin{array}{l}\text { The level of shared goals of the union (union } \\
\text { heterogeneity) and the level of direction within the } \\
\text { employing organisation (employer equivocality) } \\
\text { determine the role of accounting information in not-for- } \\
\text { profit bargaining. It is most useful where union } \\
\text { heterogeneity is high (low level of shared goals) and } \\
\text { where employer equivocality is low (the organisation has } \\
\text { clear, well-defined lines of responsibility and authority). }\end{array}$ \\
\hline
\end{tabular}

\subsubsection{Empirical studies on the effect of collective wage bargaining on the process of financial accounting}

Studies discussed in this section focus on the impact of collective wage bargaining on the process of financial accounting. This line of research hypothesises that 
companies aim to reach favourable settlements via the selection of a set of accounting procedures which decrease earnings or, in the context of forecasts, by underestimating earnings numbers. Earnings management studies in this setting have been conducted by Liberty and Zimmerman (1986), Yamaji (1986), DeAngelo and DeAngelo (1991), Mautz and Richardsen (1992), Waterhouse et al. (1993), Cullinan and Knoblett (1994) and Konings et al. (1998).

Liberty and Zimmerman (1986) were among the first to explore collective wage bargaining as a possible incentive for earnings management. They used archival evidence from 105 unionised US companies over the period 1968-1981 to study time series of annual and quarterly (unexpected) earnings and on accruals around the periods in which the companies in the treatment group were involved in collective wage bargaining. The time series were compared to those of a control group not involved in bargaining. They failed to present evidence that quarterly and annual reported earnings were suppressed around the time of collective wage bargaining. They also studied the effect of unionisation on managerial accounting decisions. Again, no significant results were found. Three explanations for these findings were suggested: (1) companies had no incentives to manage their earnings because they performed poorly already, (2) companies did not manipulate the earnings because they believed trade unions would undo the manipulations, and (3) the test was not strong enough to detect earnings management.

Yamaji (1986) studied financial accounting decisions in collective wage bargaining by comparing the earnings numbers forecasts of Japanese companies closing their books in March, just before the start of the collective wage bargaining season, with those closing in November or December. Forecasts of the first group of companies could not be used in collective wage bargaining, while forecasts of the second group could be used by trade unions. Consequently, the second group of companies were expected to forecast more pessimistically. For both groups of companies, the ratios "forecasted number of sales divided by realised number of sales" and "forecasted operating income divided by realised operating income" were compared. The results revealed no differences between the sales ratio among the two groups. However, companies closing their books in November-December substantially underestimated earnings as compared to the March closers (Yamaji, 1986, Exhibit 8). So, NovemberDecember closers signalled limited ability to pay via a manipulation of forecasts of earnings numbers, because according to Yamaji (1986, p.22) "if the amount of sales can be estimated with a high certainty of accuracy, the amount of operating income may also be accurately estimated".

DeAngelo and DeAngelo (1991) conducted case studies and used archival evidence 
to document managerial accounting decisions of major US domestic steel producers during a request for union concessions. They looked at earnings and operating cash flow trends of seven steel producers from 1980 until 1988. They found that reported net earnings were lower during union negotiations than in other years. Losses reported in bargaining years were largely determined by real restructuring decisions which could also have been taken during non-bargaining years. Other stakeholders also sacrificed to overcome the financial troubles of the companies they were involved with, but to a lesser extent than employees did. In particular, the reduction of the compensation of top management was more symbolic than actual to "foster a general attitude that financial sacrifices are required by all stakeholders".

Mautz and Richardson (1992) examined the impact of collective wage bargaining on financial reporting decisions regarding inventory valuations, depreciation and investment tax credits. The focus was on accounting accruals and on accounting method changes. Data on outcomes of US wage negotiations affecting 1,000 or more employees in the period 1983-1987 were used. The corporate annual reports of a selection of these companies were compared with those of a control sample of companies that were not involved in wage negotiations during this period. The authors addressed the question of whether companies engaged in collective wage bargaining more often make earnings decreasing accounting changes. In both the treatment and the control group these type of changes almost never took place, suggesting that collective wage bargaining objectives did not drive managerial accounting decisions. Even though the outcomes did not suggest that companies in the sample manipulated their earnings, this does not imply that collective wage bargaining is no incentive for companies to manage earnings. The authors believed that opportunities for earnings management are not randomly determined across companies. In fact, earnings management was expected to be less difficult for smaller companies that do not face statutory audits.

Waterhouse et al. (1993) focused on the impact of industrial disputes on the disclosure of accounting information. They studied 673 public disclosures of accounting information made by four Canadian companies facing strikes. The authors screened print media on the disclosure frequency of accounting information of these four companies. To detect interactions, the disclosures were analysed qualitatively and through network-analytic techniques. It was found that the four companies voluntarily disclosed accounting information for strategic purposes in periods surrounding strikes, to influence opportunities and threats and to respond to the actions of others.

Cullinan and Knoblett (1994) studied the impact of unionisation on US companies' 
choices for inventory and depreciation systems. Unionisation was measured by the percentage of the company's employees covered by the collective wage bargaining contract. The results were mixed. In the main sample, no significant relationships were found between companies' degree of unionisation and their inventory policy choices. The same was true for the companies' depreciation policies. However, in some industries, highly unionised companies were more likely to select LIFO (or some combination) over FIFO. This choice usually has an earnings decreasing effect. At industry-level, the effect of unionisation on depreciation policy choice was not found.

Konings et al. (1998) studied the earnings management behaviour of Belgian companies with strong trade unions versus companies with low trade union activity. Low trade union activity was defined as companies without strikes or labour disputes in a three year period. The occurrence of earnings management was investigated by focusing on the behaviour of discretionary accruals. No differences were found between companies with high and companies with low trade union activity. According to the authors, one possible explanation for the findings is that trade unions are sophisticated users of corporate annual reports, who will undo accounting manipulations, and as a consequence, companies do not benefit from manipulating earnings in this setting.

The main findings of the studies discussed in this section are summarised in Table 3.3 . 
Table 3.3: Summary of studies on the effect of collective wage bargaining on the process of financial accounting.

\begin{tabular}{|c|c|c|}
\hline Authors & Context & Main findings \\
\hline $\begin{array}{l}\text { Liberty and } \\
\text { Zimmerman } \\
\text { (1986) }\end{array}$ & $\begin{array}{l}\text { Analysis of annual and quarterly (unexpected) } \\
\text { earnings and of accruals around the periods in } \\
\text { which } 105 \text { unionised US companies in 1968-1981 } \\
\text { were involved in collective wage bargaining. }\end{array}$ & $\begin{array}{l}\text { No evidence that quarterly and } \\
\text { annual reported earnings were } \\
\text { suppressed around the time of } \\
\text { collective wage bargaining. }\end{array}$ \\
\hline $\begin{array}{l}\text { Yamaji } \\
(1986)\end{array}$ & $\begin{array}{l}\text { Comparison of earnings numbers forecasts of } \\
\text { Japanese companies closing their books in March, } \\
\text { just before the start of the collective wage } \\
\text { bargaining season, with those closing in November } \\
\text { or December. }\end{array}$ & $\begin{array}{l}\text { Companies closing their books } \\
\text { in November-December } \\
\text { substantially underestimated } \\
\text { earnings as compared with the } \\
\text { March closers. }\end{array}$ \\
\hline $\begin{array}{l}\text { DeAngelo } \\
\text { and } \\
\text { DeAngelo } \\
\text { (1991) }\end{array}$ & $\begin{array}{l}\text { Earnings and operating cash flow trends of seven } \\
\text { US steel producers during a request for union } \\
\text { concessions. }\end{array}$ & $\begin{array}{l}\text { Reported net earnings were } \\
\text { lower in years of negotiations } \\
\text { than in other years. } \\
\text { Restructuring decisions were } \\
\text { taken in bargaining years. }\end{array}$ \\
\hline $\begin{array}{l}\text { Mautz and } \\
\text { Richardsen } \\
\text { (1992) }\end{array}$ & $\begin{array}{l}\text { Impact of bargaining on US companies' accounting } \\
\text { choices regarding inventory valuations, } \\
\text { depreciation and investment tax credits. }\end{array}$ & $\begin{array}{l}\text { Earnings decreasing accounting } \\
\text { changes were not driven by } \\
\text { bargaining objectives. }\end{array}$ \\
\hline $\begin{array}{l}\text { Waterhouse } \\
\text { et al. (1993) }\end{array}$ & $\begin{array}{l}\text { Disclosure policies of four Canadian companies } \\
\text { facing strikes. }\end{array}$ & $\begin{array}{l}\text { Information was disclosed } \\
\text { voluntarily for strategic purposes } \\
\text { in periods surrounding strikes } \\
\text { and it was used to influence } \\
\text { opportunities and threats and to } \\
\text { respond to the actions and } \\
\text { disclosures of the other party. }\end{array}$ \\
\hline $\begin{array}{l}\text { Cullinan and } \\
\text { Knoblett } \\
\text { (1994) }\end{array}$ & $\begin{array}{l}\text { Impact of unionisation on US companies' inventory } \\
\text { and depreciation system choices. }\end{array}$ & $\begin{array}{l}\text { In some industries, highly } \\
\text { unionised companies were more } \\
\text { likely to select LIFO (or some } \\
\text { combination) over FIFO. No } \\
\text { effect of unionisation on } \\
\text { depreciation policy choice. }\end{array}$ \\
\hline $\begin{array}{l}\text { Konings et al. } \\
\text { (1998) }\end{array}$ & $\begin{array}{l}\text { Belgium companies with strong trade unions } \\
\text { manipulate earnings downward compared to } \\
\text { companies with low trade union activity. }\end{array}$ & $\begin{array}{l}\text { No evidence indicating that } \\
\text { companies with strong trade } \\
\text { unions manipulate earnings } \\
\text { more strongly. }\end{array}$ \\
\hline
\end{tabular}

\subsubsection{Studies on the perceptions of trade unions on independent auditors}

Literature on trade unions' perceptions of independent auditors is scarce. We are aware of only two studies that deal with this issue from an empirical angle. Both studies are conducted by Schilder (1994a and 1994b). In both studies the focus is on the Dutch collective wage bargaining setting.

Schilder (1994a) interviewed Stekelenburg, chairman of the largest Dutch trade union federation Federated Dutch Trade Union Movement (Federatie Nederlandse Vakbeweging, or FNV) on auditor independence. Stekelenburg considered statutory audits of corporate annual reports to be important. He also identified threats to auditor 
independence. One way to prevent impairment of independence is a mandatory rotation of the auditor after a certain period. Stekelenburg is a supporter of a mandatory rotation of the auditor, but he does not see the need for a mandatory rotation of the audit firm. Further, Stekelenburg believes the image of the auditor as an independent expert is not served by auditors conducting both audit and management advisory services with the same client. To prevent auditors losing an independent attitude, Stekelenburg suggested that the advisory fee should not exceed $25 \%$ of the audit fee. He also suggested to increase the role of the auditor in relations with the works council. For instance, the auditor should be invited to discuss the management letter with the works council, so that they are directly informed on audit findings.

Schilder (1994b) also interviewed Westerlaken, chairman of the Dutch Christian National Trade Union Federation (Christelijk Nationaal Vakverbond or CNV) on auditor independence. Westerlaken supports a mandatory rotation of the audit firm after a fixed period, to strengthen auditor independence. He also supports a fixed engagement period for statutory audits, for a period of four years with the possibility of one re-election. Auditors should not be allowed to conduct non-audit services above a certain percentage of the audit fee, and they should be trained in public affairs and communication. Westerlaken also suggested to increase the auditor's involvement with the works councils. He made a case for giving works councils a role in appointing the auditor, as they do in Belgium.

The main findings of the studies discussed in this section are summarised in Table 3.4 .

Table 3.4: Summary of studies on the perceptions of trade unions regarding independent auditors.

\begin{tabular}{|c|c|c|}
\hline Authors & Context & Main findings \\
\hline $\begin{array}{l}\text { Schilder } \\
\text { (1994a) }\end{array}$ & $\begin{array}{l}\text { Interview with Stekelenburg. } \\
\text { chairman of the FNV (a large } \\
\text { Dutch trade union federation) } \\
\text { on auditor independence. }\end{array}$ & $\begin{array}{l}\text { Stekelenburg supports a mandatory rotation of the } \\
\text { audit partner after a certain period, but he does not } \\
\text { see the need for a mandatory rotation of the audit firm. } \\
\text { The advisory fee should not exceed } 25 \% \text { of the audit } \\
\text { fee. The works council should be directly informed of } \\
\text { audit findings. For instance, the auditor could present } \\
\text { the management letter to the works council. }\end{array}$ \\
\hline $\begin{array}{l}\text { Schilder } \\
\text { (1994b) }\end{array}$ & $\begin{array}{l}\text { Interview with Westerlaken, } \\
\text { chairman of the CNV (a large } \\
\text { Dutch trade union federation) } \\
\text { on auditor independence. }\end{array}$ & $\begin{array}{l}\text { The chairman supports a mandatory rotation of the } \\
\text { audit firm after a fixed period, and a fixed engagement } \\
\text { period for statutory audits. Auditors should not conduct } \\
\text { non-audit services above a certain percentage of the } \\
\text { audit fee. The works councils should be involved in } \\
\text { appointing the auditor. }\end{array}$ \\
\hline
\end{tabular}




\section{Evaluation}

Empirical research on the interface of accounting, auditing and collective wage bargaining is not voluminous. The existing literature is typically rooted in the US industrial relations setting, but from the mid 1980s on, an increasing number of studies are based on other settings, including that of the UK (see for instance Bougen et al., 1990, McBarnett et al., 1993), Canada (Amernic, 1985; Elias, 1990; Waterhouse et al., 1993) and Japan (Yamaji 1986; Morishima, 1991).

Based on a summary of the empirical studies above, it can be concluded that:

(1) Trade unions indeed use accounting information in collective wage bargaining both in the profit sector (Cooper and Essex, 1977; Palmer, 1977; Foley and Maunders 1979; Mautz, 1990; Clarke and Craig, 1992, McBarnet et al., 1993) and in the notfor-profit sector (Ward, 1987). This is true for trade union officials directly involved in bargaining (Cooper and Essex, 1977; Palmer, 1977) and for those responsible for bargaining preparations working at research units at trade union headquarters (Foley and Maunders, 1979; McBarnet et al., 1993). Accounting information is used for many objectives, including wage bargaining, bargaining in the cases of mergers, closures or massive redundancies, bargaining on health and safety issues, and profit based bonuses (McBarnet et al., 1993). This information appears to be relevant indirectly as well, because it was found that ability to pay was an important argument in collective wage bargaining (Ward, 1987; Mautz, 1990) and accounting information as contained in corporate annual reports indicates the employers' ability to pay (Mautz, 1990; Clarke and Craig, 1992). However, trade unions may also reject the relevance of accounting information in collective wage bargaining (Bougen et al., 1990). Accounting information has limitations that decrease its usefulness to trade unions. For instance, from the perspective of trade union bargainers, it lacks reliability (Palmer, 1977). On the other hand, the usefulness of accounting information is also hampered by a lack of understanding on the side of the trade union (Ward, 1987; Mautz, 1990).

(2) The impact of the disclosure of accounting information on the process of collective wage bargaining is rather complicated: it helps to reach a fair settlement (Amernic and Aranya, 1990), it allows the parties to keep on talking, especially in a hostile bargaining environment (Amernic and Aranya, 1990; Morishima, 1991), and it may shorten wage talks (Morishima, 1991). However, it may also decrease a trade union's possibilities for high wage claims (Morishima, 1991), or, put more carefully, information symmetry does not necessarily lead to higher wage claims (Elias, 1990; Chalos et al., 1991). Moreover, disclosure seems to lessen industrial conflict (Elias, 
1990), and it appears to stimulate integrative bargaining solutions (Chalos et al., 1991).

(3) The process of collective wage bargaining may also have the capacity to influence the financial accounting process itself, though the empirical results in this respect are mixed. Liberty and Zimmerman (1986), Mautz and Richardsen (1992) and Konings et al. (1998) found no evidence pointing to earnings management. Yamaji (1986), and DeAngelo and DeAngelo (1991) reported earnings (forecasts) manipulations, while Cullinan and Knoblett (1994) presented mixed results. One possible explanation for the conflicting results is that the advantages of suppressed earnings numbers in collective wage bargaining, resulting from manipulations, are offset by conflicting incentives elsewhere, for instance in the managementshareholder relation. If managers across companies perceive this trade-off differently, mixed evidence may be found. Industrial disputes may also cause companies to release accounting information tactically (Waterhouse et al., 1993).

(4) As far as we know, trade union perceptions of independent auditors have been studied empirically only in the Dutch setting. However, based on accounting studies, it can be concluded that the scope of auditor duties and auditor independence are relevant issues to trade unions, since they prefer audited accounting information over non-audited information (Palmer, 1977). This is confirmed by Schilder (1994a and 1994b), who found that Dutch trade union leaders consider auditor independence to be an essential ethical requirement. Union leaders perceive auditors in general as independent from their clients; however, they do see potential threats to auditor independence. To mitigate these threats, they suggest a mandatory rotation of auditors and upper bounds for advisory fees for audit clients. They also have suggestions for extending the scope of auditor duties. One suggestion is to inform works councils directly on the main audit findings (Schilder, 1994a and 1994b).

\subsection{Four research opportunities and this dissertation}

\subsubsection{The role of accounting and auditing in contracts: a study of non- executive employee contracts (Chapter 4)}

Sections 3.2.2 and 3.2.3 make clear that the usefulness of accounting information to trade unions and the role of accounting information in collective wage bargaining has been investigated in various ways. The focus, however, has been on the role of accounting information as an input in trade union decision making and on the role of accounting information on the process of collective wage bargaining, while no 
attention at all has been paid to the role of accounting information as a mechanism used in collective bargaining contracts to distribute cash flows between employees and other stakeholders of the company. Yet, Section 2.2 of this dissertation presented the contracting cost theory and suggested this role in particular for accounting information in management-trade union contracting. One way to learn more about the use of accounting information is to focus on the contents of collective bargaining contracts. Documenting the role of accounting information in contracts between companies and stakeholders is not new. For instance, the role of accounting information in US debt contracts' and in management compensation plans has been documented before. ${ }^{10}$ However, as far as we know, no systematic empirical analysis has been conducted on the contents of explicit contracts between companies and nonmanagerial employees. Exploring the use of accounting and auditing in explicit contracts between employers and trade unions is important not only because this sheds light on the demand, but also because it allows an exploration of the extent to which accounting based provisions in collective bargaining contracts provide incentives for earnings management. This adds to previous studies on the impact of collective wage bargaining on financial accounting policies as discussed in Section 3.2.4. Schilder (1994a and 1994b) showed that trade union leaders see a role for auditors in collective wage bargaining. However, evidence regarding the extent to which auditing plays a role in collective bargaining contracts is scarce at this moment. Chapter 4 studies this role and presents empirical evidence on this.

\subsubsection{The use and perceived importance of corporate annual reports: a study among trade union bargainers (Chapter 5)}

The overview presented in Section 3.2 shows that, although accounting researchers have explored the usefulness of accounting information to trade unions in different settings, the perceived usefulness of corporate annual reports, as the standard output of the financial accounting process, in collective wage bargaining is not documented extensively. Many questions are open in this field, including: (1) are corporate annual reports used in collective wage bargaining?, (2) what is the relative importance of corporate annual reports as an information source in periodic collective wage bargaining?, (3) what is the relative importance of segments of corporate annual reports, and (4) what variables determine the usage and perceived importance of accounting information? In particular, the use of data from industrial relations settings on the European continent is interesting. This allows a comparison with the results of studies that focus on related issues in collective wage bargaining settings in the Anglo-Saxon countries, and with the results of studies among other user groups (shareholders, financial analysts and the like) of corporate annual reports. Chapter 5 
is an attempt to narrow the gap between previous research on the usefulness of accounting information to trade unions and user oriented studies among other users of corporate annual reports.

\subsubsection{The audit expectations gap: a study among trade union bargainers (Chapter 6)}

The literature on the perceptions of trade unions regarding auditors and audits as reviewed in Section 3.2.5 reveals that there are some indications that trade unions define the scope of auditor duties more broadly than does the audit profession and their clients. For instance, Schilder (1994a, 1994b) found that trade unions think that auditors should amplify their role, so that they have some direct contact with works councils. This points toward the existence of an audit expectations gap. At the same time, however, it must be noted that so far no research has been conducted to measure the existence and nature of the audit expectations gap of trade union bargainers in a more systematic way. As a result, the question of whether trade union bargainers have an audit expectations gap has not yet been answered. This is peculiar, because in both the academic literature and the financial press much attention has been paid to the audit expectations gap of the providers of financial capital. Chapter 6 of this dissertation will fill this gap in the research. Based on the views of trade union bargainers, it will document the perceived and expected performance of auditors, and the expected scope of auditor duties to map the size and the variation of the audit expectations gap. Based on the results, steps may be taken to increase the value of audits to trade unions and to the employees they represent.

\subsubsection{The independence of auditors: a study among trade union bargainers (Chapter 7)}

From the research overview presented in Section 3.2.1, it is clear that trade union bargainers' perceptions of the reliability of accounting information have scarcely been looked into. Considering the earnings management studies in this field as cited in Section 3.2.4, there is some reason for doubt concerning companies' incentives for disclosing true and fair accounting information. However, so far, accounting scholars have been involved primarily in documenting managerial accounting decisions in this context. It is unclear whether trade unions consider corporate annual reports free of bias. In order for corporate annual reports to be regarded as free of bias, users must perceive auditors as independent from executive management. Section 3.2.5 summarised two interviews with trade union leaders on auditor independence. That 
section made clear that auditor independence is a relevant issue to trade unions. To contribute to the literature, Chapter 7 of this dissertation reports the results of a survey among a sample of trade union bargainers on the perceived independence of external auditors. This essay attempts to fill the gap between the reliability issues in the trade union niche of user oriented research on the one hand, and research on auditor independence among trade union leaders and other users of auditor services on the other. 


\section{Chapter 3: Overview of Previous Research and Research Opportunities}

\section{Notes}

1. For reviews of the literature on the use of accounting information by trade unions before 1970, see Palmer (1977, Chapter 2) and Foley and Maunders (1979, Chapter 2).

2. A discussion of studies that focus on statistical relations between financial variables and wages is beyond the scope of this overview. Examples of studies in that line of research are Slichter (1950), Lipsey and Steuer (1961), Bhatia (1962), Sparks and Wilton (1971), Horwitz and Shabahang (1971), Kumar (1972), Kalachek and Raines (1976), Foley and Maunders (1979), Peel and Pope (1984), Gregory et al. (1985), Gregory et al. (1986), Carruth and Oswald (1987), Dickens and Katz (1987), Gregory et al. (1987), Blanchflower and Oswald (1988), Kleiner and Bouillon (1988), Nickell and Wadhwani (1990), Blanchflower et al. (1990).

3. For an overview of studies on the use of accounting information by individual employees, see Lewis et al. (1984), Gray et al. (1987), Parker (1988), Parker et al. (1988).

4. See Foley and Maunders (1979, Chapter 5).

5. See Foley and Maunders (1979, p.133).

6. See Chapter 2 of this dissertation for an explanation of these subprocesses of collective wage bargaining.

7. See Amernic and Craig (1992, p.65).

8. See Amernic and Craig (1992, p.65).

9. See for instance Duke and Hunt (1990) and Press and Weintrop (1990 and 1991).

10. See for instance Healy (1985). 


\section{Chapter 4 \\ The Role of Accounting and Auditing in Contracts: \\ A study of non-executive employee contracts}

\subsection{Introduction}

In this chapter the focus is on the role of accounting and auditing in collective bargaining contracts (CBCs) between employers and trade union bargainers. ${ }^{\prime} \mathrm{CBCs}$ may contain specific arrangements called employee profit sharing plans (EPSPs)? We will also investigate the role of accounting and auditing in these plans.

Based on a review of theories used in the empirical financial accounting literature, Chapter 2 concluded that accounting information and auditing are potentially relevant to trade unions. Previous studies, predominantly US and UK based, focused on the use of accounting information by trade unions, and on the impact of accounting information on the bargaining process. Chapter 3 summarised and discussed these studies. So far, accounting researchers have largely ignored the contents of $\mathrm{CBCs}$ and EPSPs. This is peculiar, since studying the contents of CBCs and EPSPs is a natural starting point for exploring the roles of accounting and auditing in non-executive employee contracting. As Chalos et al. (1991, p.432) note:

"(...) the role of financial information in labor contracts is a fundamental but unexplored area of accounting research".

Ball and Smith (1992, p.346) also indicate that this is a niche in accounting research: "(...) little knowledge is available concerning the use of accounting numbers in determining bonuses, salaries, (...). for employees other than senior managers".

This chapter is a first attempt to fill this gap. The central research question this chapter aims to answer is:

What is the role of accounting and auditing in collective bargaining contracts and employee profit sharing plans, and what explains the variation of this role?

The setting of this study is the Netherlands. Detailed research questions and 
hypotheses will be presented below.

This chapter is organised as follows. Section 4.2 briefly discusses the theoretical framework. ${ }^{3}$ Section 4.3 presents the links to previous empirical research. Section 4.4 develops the research questions and hypotheses. Section 4.5 outlines the research method and provides a description of the data. Section 4.6 and Section 4.7 present the empirical results. Finally, Section 4.8 summarises the main findings and presents some conclusions. Section 4.6 investigates the contents of $\mathrm{CBCs}$ to assess the roles of accounting and auditing in these contracts. To learn more about the roles over time, this part compares the contents of CBCs in $1999(\mathrm{~N}=726)$ with that of CBCs in 1992 $(\mathrm{N}=606)$. As will be seen, the role of accounting and auditing in $\mathrm{CBCs}$ is in all cases restricted to defining EPSPs. To learn more about the role of accounting and auditing in that setting, the EPSPs $(\mathrm{N}=63)$ found in the sample of CBCs effective in 1999 $(\mathrm{N}=726)$ will be analysed in Section 4.7.

\subsection{Theoretical framework}

Here we will limit the analysis to the contracting cost theory. As is explained in more detail in Chapter 2, competition forces companies to write contracts that minimise agency costs and maximise the value of the company. If companies have sub-optimal contracts, they will under-perform and, unless there are some offsetting benefits, they cannot survive in the long run. Accounting can be used in contracts to reduce agency costs. For instance, interest coverage ratios in lending contracts aim to control the conflict between shareholders and bondholders. The contractual use of accounting numbers requires monitoring for breach of contract. Independent audits play this role, as explained in Chapter $2 .^{4}$ There is also a need for efficient contracts in employee contracting. This explains why accounting and auditing may play a role in $\mathrm{CBCs}$ and EPSPs.

\subsection{Relations to previous empirical research}

This chapter has several links to previous research. First, it is linked to research on the role of accounting information in contracts. Research in this area is predominantly conducted in the Anglo-Saxon world, with a focus on debt contracts and executive wage contracts. ${ }^{5}$ This chapter contributes to the literature by investigating the role of accounting information in CBCs and EPSPs, which are contracts with another group of corporate stakeholders. Second, this chapter extends previous studies on trade union bargainers' demand for accounting information. This demand is studied in 
several ways, as is summarised in Chapter 3. None of the previous studies, however, has investigated contractual arrangements to derive the usefulness of accounting information to trade union bargainers, as is one of the purposes of this chapter. ${ }^{\circ}$ Third, previous research has looked at the role of auditing in financial contracting', but not at the role in non-executive employee contracting.' This chapter aims to add to the literature by exploring CBCs and EPSPs to learn more about the role of auditing in employee contracting. Fourth, this chapter is linked to research on the impact of accounting-based contracts on earnings management. ${ }^{90}$ One approach to study this is by investigating the accounting choices of companies directly. Another approach is to explore contractual arrangements to see if and how accounting information is used.

\subsection{Development of the research questions and hypotheses}

The first part of this chapter investigates the contents of CBCs. This chapter will investigate CBCs effective in 1999 and 1992. CBCs from two years are used for two reasons. First, because a larger subset of $\mathrm{CBCs}$ is investigated, a more representative picture is provided. Second, using CBCs from non-consecutive years provides an opportunity to investigate whether the role of accounting and auditing in $\mathrm{CBCs}$ has changed over time. We pose the following research questions:

RQ1 What is the role of accounting in CBCs?

RQ2 What is the role of auditing in CBCs?

Chapter 1 introduced the dual collective wage bargaining system of the Netherlands and Appendix B at the end of this dissertation provides some further information on this. In some companies, trade unions bargain directly with the company (corporatelevel bargaining or CL-bargaining); in other companies trade unions bargain with industry representatives (industry-level bargaining or IL-bargaining).

This chapter is exploratory in that we do not know whether accounting and auditing do play a role in CL-contracts and IL-contracts. However, we do know that there is a need for efficient contracting at both the corporate-level and the industry-level. We also know that, compared to IL-contracts, CL-contracts are more detailed." This is because CL-contracts meet the specific desires of one group of employees and they are based on the economic possibilities of the company concerned. IL-contracts cover employees across companies. Because there is diversity among the companies in the industry, IL-contracts are more general in nature, providing a framework that can be used by parties to make more detailed arrangements at corporate-level. ${ }^{12}$ Therefore, if accounting and auditing do play a role in $\mathrm{CBCs}$, we expect them to play a role more 
often in CL-contracts compared to IL-contracts. Therefore, we hypothesise that:

H1 Accounting more often plays a role in $\mathrm{CL}$-contracts than in IL-contracts.

H2 Auditing more often plays a role in $\mathrm{CL}$-contracts than in IL-contracts.

\subsection{Research method and data description}

This chapter explores archival evidence. CBCs are available for public inspection at the Ministry of Social Affairs and Employment in The Hague. The selection of the sample is based on four lists compiled by the Dutch Ministry of Social Affairs and Employment. These lists were coded:

(1) CRS514/Ondernemingscao 's/op naam/30/03/1999 (MSZW, 1999a);

(2) CRS5I2/Bedrijfstakcao 's/op naam/30/03/1999 (MSZW, 1999b);

(3) DCA/AFD.CAO/Ondernemingscao 's op SBI-code-BIR-29/06/92 (MSZW, 1992a);

(4) DCA/AFD.CAO/Bedrijfstakcao's op SBI-code-BIR-29/06/92 (MSZW, 1992b).

The sample consists of standard CBCs effective in the Dutch for-profit sector. CBCs that contain specific arrangements like early retirement or redundancies were deleted from the dataset. The final sample consists of $1,332 \mathrm{CBCs}$. The composition of the sample is summarised in Table 4.1 .

Table 4.1: Composition of the sample CBCs effective in 1999 and in 1992.

\begin{tabular}{|c|c|c|c|c|c|c|}
\hline & & Total & $\begin{array}{r}1999 \\
\mathrm{CL} \\
\end{array}$ & $\begin{array}{r}1999 \\
\text { IL }\end{array}$ & $\begin{array}{r}1992 \\
\mathrm{CL} \\
\end{array}$ & $\begin{array}{r}1992 \\
\text { IL }\end{array}$ \\
\hline & CBCs in the Netherlands: & 2,520 & 958 & 406 & 804 & 352 \\
\hline$\% 1$ & Non-standard CBCs: & 241 & 41 & 83 & 31 & 86 \\
\hline$\% 1$ & Expiration before 1-1-1999/ 1-1-1992: & 335 & 147 & 12 & 159 & 17 \\
\hline$\%$ & Adjustments: & 206 & 48 & 60 & 49 & 49 \\
\hline & Standard CBCs in the for-profit and not-for-profit sector: & $1, \overline{738}$ & $\overline{722}$ & 251 & $5 \overline{65}$ & $2 \overline{200}$ \\
\hline \multirow[t]{5}{*}{$\%$} & Standard CBCs in the not-for-profit sector: ${ }^{13}$ & $\underline{406}$ & 198 & $\underline{49}$ & 123 & $\underline{36}$ \\
\hline & Final sample of CBCs in the profit sector: & $1, \overline{332}$ & 524 & 202 & 442 & 164 \\
\hline & & & \multicolumn{4}{|c|}{ Year } \\
\hline & & & 1999 & & 992 & Total \\
\hline & $\mathrm{CL}$-contracts & & 524 & & 442 & 966 \\
\hline \multirow{2}{*}{$\mathrm{CBC}$} & IL-contracts & & 202 & & 164 & 366 \\
\hline & Total & & 726 & & 606 & 1,332 \\
\hline
\end{tabular}

a: adjustment = [(if companies or industries have more than one CBC, only one is analysed) + (early retirement contracts that have an expiration data before 1-1-1999/1-1-1992)]: CL/CL-contract=corporate-level contract; IL/L. contract= industry-level contract.

To test $\mathrm{H1}$ and $\mathrm{H} 2, \mathrm{CBCs}$ of 1999 and 1992 are pooled. The contents of the CBCs is analysed in detail, and whenever the CBCs refer to either accounting information ${ }^{14}$, 
or to (external or internal) auditing, this will be recorded. ${ }^{15}$

\subsection{The role of accounting and auditing in CBCs: empirical results}

\subsubsection{Research question 1: what is the role of accounting information in CBCs?}

Of the $1,332 \mathrm{CBCs}$ investigated, $104 \mathrm{CBCs}(7.8 \%)$ contain accounting information. In 1999, CBCs contain accounting information slightly more often than in 1992 (8.7\% versus $6.8 \%$ ). We find that in all $104 \mathrm{CBCs}$, accounting information is used to design EPSPs. Table 4.2 presents the results. Based on the chi-square test $\left(\chi^{2}=1.667\right.$; $1 \mathrm{df}$; sign. [2-tailed]: 0.195 ) it can be concluded that there is no significant difference in frequency of use of accounting information in CBCs in 1999 versus 1992.

Table: 4.2: The role of accounting information in CBCs: 1999 versus 1992.

\begin{tabular}{lccc}
\hline & \multicolumn{1}{c}{1999} & \multicolumn{1}{c}{1992} & \multicolumn{1}{c}{ Total } \\
\hline CBC with accounting information & $63(0.087)$ & $41(0.068)$ & $104(0.078)$ \\
CBC without accounting information & $663(0.913)$ & $565(0.932)$ & $1,228(0.922)$ \\
Total & 726 & 606 & 1,332 \\
\hline
\end{tabular}

$x^{2}$-test: 1.667; 1df, sign. (2-tailed): 0.195; relative scores between parentheses.

The examples below illustrate the role of accounting information as a parameter in CBCs that include an EPSP. These examples are all from CBCs effective in 1999 $(\mathrm{N}=726)$.

Example 4.1: CBC of Koninklijke PTT Nederland N.V.: $:^{16}$ "If return on sales (profit to sales) is $10.5 \%$ or more, the bonus is $3 \%$ of the annual wage. If return on sales is $8.5 \%$, the bonus is $1 \%$. If return on sales is between $8.5 \%$ and $10.5 \%$, the bonus is determined proportionally. If return on sales is less than $8.5 \%$. employees receive no bonus".

Example 4.2: CBC of Wholesale Industry of Textile Goods and Similar Goods (Groothandel in Textiel en Aanverwante Goederen): ${ }^{17}$ "(...) parties demand companies to agree upon an EPSP where employees receive a bonus of $1 \%$ of net profit".

Example 4.3: CBC of Nederlandsche Apparatenfabriek Nedap:" "In 1998 and 1999 employees receive a bonus of $6 \%$ of the profit before taxes of the parent company, excluding profit from subsidiaries".

The three examples show a high degree of diversity as to the role of accounting information in EPSPs. In all three examples, accounting information is used to define the bonus driver. In Example 4.1, the bonus driver is a ratio ("return on sales"), while in Example 4.2 it is not ("net profit"). Example 4.3 illustrates how the bonus driver 
may be adjusted ("excluding profit from subsidiaries") before the bonus pool is determined (" $6 \%$ of the profit before taxes of the parent company"). Also, the magnitude of the bonus pool differs.

\subsubsection{Research question 2: what is the role of auditing in CBCs?}

Of the $1,332 \mathrm{CBCs}, 33 \mathrm{CBCs}(2.5 \%)$ refer to auditors, including both external and internal auditors. CBCs exclusively refer to auditors for the purpose of designing EPSPs. In 1999, CBCs refer to auditors slightly more often than in 1992 (2.9\% versus $2.0 \%)$. A chi-square test $\left(\chi^{2}=1.138 ; 1 \mathrm{df} ;\right.$ sign. [2-tailed]: 0.286$)$ indicates that the difference is not significant. Table 4.3 summarises the results.

Table: 4.3: The role of auditing in CBCs: 1999 versus 1992.

\begin{tabular}{lccr}
\hline & 1999 & 1992 & \multicolumn{1}{c}{ Total } \\
\hline CBCs that refer to auditing & $21(0.029)$ & $12(0.020)$ & $33(0.025)$ \\
CBCs that don't refer to auditing & $705(0.971)$ & $594(0.980)$ & $1,299(0.975)$ \\
Total & 726 & 606 & 1,332 \\
\hline
\end{tabular}

2.test: 1.138; 1df, sign. (2-tailed): $0.286 ; C B C=$ collective bargaining contract, relative scores between parentheses.

The analysis of the 1,332 CBCs in the sample reveals that in both years, the role of auditors in CBCs is twofold: auditing the annual accounts, and determining whether there is room for a bonus, as illustrated below.

Example 4.4: CBC of the Rubber and Plastics Industry (Rubber-en Kunststofindustrie):"19 "(...) Employees receive a minimum bonus of $3 \%$ of their annual wage (...) unless an auditor's report indicates that in the last year the company has made no profit (...) the minimum bonus is $3 \%$, of which $1 \%$ is independent of the auditor's report and $2 \%$ depends on the auditor's report".

Example 4.5: CBC of CSM Suiker B.V.20 "(...) each year the employees receive a bonus depending on the net profit (...). An auditor has to determine whether the net profit allows a bonus reward".

In both examples, the employee bonus depends directly on the auditor's report. In Example 4.5 the bonus depends on the auditor's professional judgement. Parties possibly perceive the contractual arrangement as in Examples 4.4 and 4.5 to be efficient alternatives for defining EPSPs in more detail.

Internal as well as external auditors appear to play a role in CBCs, as shown in Example 4.6. This is interesting because internal auditors are typically not independent from executive management. Obviously, in this case trade union bargainers do not consider the dependence of auditors to be a threat to their 
objectivity.

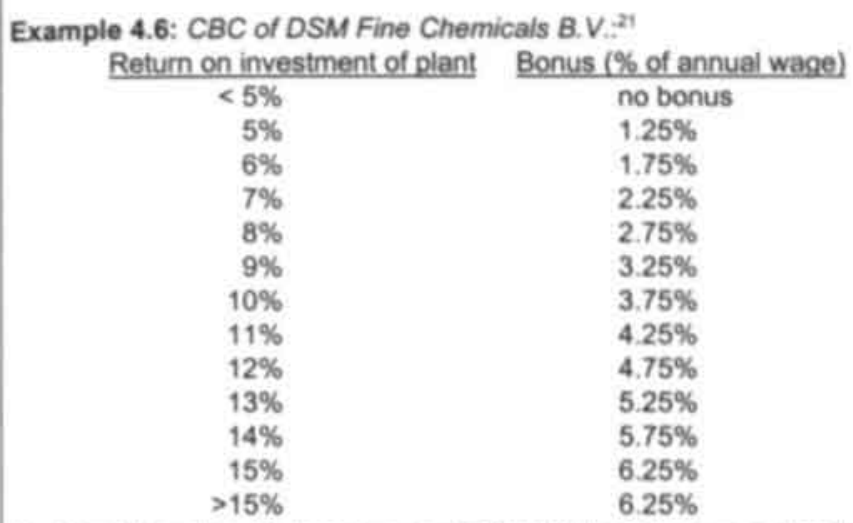

"(...) the internal audit department of DSM N.V has to issue a standard unqualified auditor's report with regard to the calculation of the employee bonus."

\subsubsection{Hypothesis 1: Accounting more often plays a role in CL-contracts than in IL-contracts}

Table 4.4 shows that the $104 \mathrm{CBCs}$ that contain accounting information include 97 CL-contracts $(10.0 \%)$ and $7 \mathrm{IL}$-contracts $(1.9 \%)$. Based on the chi-square test $\left(\chi^{2}=24.366 ; 1 \mathrm{df} ;\right.$ sign. [1-tailed]: 0.000$) \mathrm{H} 1$ is supported.

Table: 4.4: Accounting information in CBCs in 1999 and 1992: CL-contracts versus IL-contracts.

\begin{tabular}{lccc}
\hline & CL-contracts & IL-contracts & \multicolumn{1}{c}{ Total } \\
\hline CBCs that refer to accounting information & $97(0.100)$ & $7(0.019)$ & $104(0.078)$ \\
CBCs that don't refer to accounting information & $869(0.900)$ & $359(0.981)$ & $1,228(0.922)$ \\
Total & 966 & 366 & 1,332 \\
\hline
\end{tabular}

$\chi^{2}$-test: 24.366; 1df, sign. (1-tailed): 0.000; CL-contract: corporate-level contract; IL-contract: industry-level contract; relative scores between parentheses.

\subsubsection{Hypothesis 2: Auditing more often plays a role in CL-contracts than in IL-contracts}

Table 4.5 shows that the $33 \mathrm{CBCs}$ that refer to auditing include $26(2.7 \%) \mathrm{CL}$ contracts and $7(1.9 \%)$ IL-contracts. Based on the chi-square test $\left(\chi^{2}=0.667 ; 1 \mathrm{df} ;\right.$ sign. [1-tailed]: 0.207$) \mathrm{H} 2$ is not supported, although the difference is in the expected direction. 
Table: 4.5: Auditing in CBCs in 1999 and 1992: $\mathrm{CL}$-contracts versus IL-contracts $(\mathrm{N}=1,332)$.

\begin{tabular}{lccr}
\hline & CL-contracts & IL-contracts & \multicolumn{1}{c}{ Total } \\
\hline CBC that refer to auditing & $26(0.027)$ & $7(0.019)$ & $33(0.025)$ \\
CBC that don't refer to auditing & $940(0.973)$ & $359(0.981)$ & $1.299(0.975)$ \\
Total & 966 & 366 & 1,332 \\
\hline
\end{tabular}

$x^{2}$-lest: 0.667; 1df, sign. (1-tailed): $0.207 ; \mathrm{CL}$-contract corporate-level contract; IL-contract industry-level contract; relative scores between parentheses.

\subsubsection{Concluding remarks}

The evidence presented in this chapter so far suggests that the overall role of accounting information and of auditing in CBCs is limited, and that there is no significant increase in 1999 compared with 1992. In comparison with IL-contracts, CL-contracts more often contain accounting information and slightly more often refer to auditing. The latter difference, however, is not significant. In both years, there is a strong relationship between the role of accounting information and of auditing in CBCs on the one hand, and the occurrence of EPSPs in CBCs on the other. As a matter of fact, $\mathrm{CBCs}$ only contain accounting information if EPSPs are included. The role of auditing is also restricted to CBCs that contain EPSPs. This conclusion justifies a closer analysis of the role of accounting and auditing in EPSPs, which is the aim of the next section.

\subsection{The role of accounting and auditing in EPSPs: empirical results}

\subsubsection{Introduction}

The purpose of this section is to look more closely at the EPSPs in the 1999 CBCs, in order to learn more about the roles of accounting information and auditing in this setting. We use content analysis to study the parameters of EPSPs. ${ }^{22}$ Content analysis is a common social sciences research methodology that is particularly suitable for studying aspects of communication. Weber $(1985$, p.9) defines content analysis as "a research methodology that utilises a set of procedures to make valid inferences of text". With regard to the usefulness of content analysis, Lee and Peterson (1997, p.959) argue "content analysis is especially useful in the assessment of cognitive constructs (...) spoken and written reports are an obvious source of information about how an individual thinks about matters, and many such reports can be found in data archives". Harris (1996) emphasises the usefulness of content analysis for negotiation research.

Content analysis begins with the design of a coding protocol. This protocol must 
assure that items under investigation are classified systematically and as objectively as possible. The content analysis technique requires trained coders to code the items. Reliability in content analysis is determined by comparing the codings of different coders and measuring the level of agreement.

Since content analysis is an intensive and time-consuming research technique, only the 63 EPSPs found in the $1999 \mathrm{CBCs}$ will be subjected to content analysis.

The author and two students served as coders. Prior to the analysis, the coders trained agreement on a subset of the data. In the coding protocol, six categories for coding the characteristics of the EPSP were identified, as follows:

(1) What is the bonus driver? (e.g. reported net profit, operating profit, ROI etc.) (see column [iii] in Table 4.6).

(2) Is there a threshold or lower boundary of the bonus driver $(>0)$ after which employees receive a bonus? (yes, no) (see column [iv] in Table 4.6).

(3) Is there a ceiling or upper boundary of the bonus driver at which the bonus is maximised? (yes, no) (see column [v] in Table 4.6).

(4) Is the bonus driver (e.g. reported net profit, operating profit, ROI) adjusted before the bonus is determined? ${ }^{23}$ (yes, no) (see column [vi] in Table 4.6).

(5) Is the employee bonus maximised at the level of the individual employee, and if so, what is the maximum bonus? (as a percentage of the annual wage) (see column [vii] in Table 4.6).

(6) Is an (external or internal) auditor mentioned in the context of the EPSP? (yes, no) (see column [viii] in Table 4.6).

Each of the coders coded 378 parameters of the sample of 63 EPSPs (six items per EPSP, see Table 4.6). In the first round the coders agreed upon 327 parameters. The reliability of the content analysis is $86.5 \%{ }^{24}$ Codings on which no agreement is reached in the first round were discussed for consensus by the author and one of the other coders prior to assigning a code.

\subsubsection{Data description}

Again we investigate the impact of bargaining level by comparing the contents of CLEPSPs and IL-EPSPs. The 63 EPSPs include 58 CL-EPSPs and $5 \mathrm{IL}$-EPSPs. For more on the CBCs see Table 4.9 in Appendix 4A at the end of this chapter.

The results of the content analysis as to the main characteristics of the 63 EPSPs investigated are summarised in Table 4.6. The EPSPs are ordered according to type 
of EPSP (first the CL-EPSPs and than the IL-EPSPs) and the number of employees covered by the EPSP (starting off with the smallest EPSPs).

Table 4.6: Part 1: The parameters of EPSPs in CBCs in $1999(\mathrm{~N}=63)$.

\begin{tabular}{|c|c|c|c|c|c|c|c|}
\hline $\begin{array}{l}\text { CL. } \\
\text { or } \\
\text { II. } \\
\text { EPSP } \\
\text { i0] }\end{array}$ & $\begin{array}{l}\text { Number of } \\
\text { employees } \\
\text { covered by } \\
\text { the EPSP } \\
\text { [i] }\end{array}$ & Bonus driver & $\begin{array}{c}\begin{array}{c}\text { Lower } \\
\text { boundary } \\
>0\end{array} \\
{[\text { [V] }}\end{array}$ & $\begin{array}{c}\text { Upper } \\
\text { boundary }\end{array}$ & $\begin{array}{l}\text { Bonus driver } \\
\text { adjusted } \\
\text { before bonus } \\
\text { is determined } \\
\text { [vi] }\end{array}$ & $\begin{array}{l}\text { Maximum bonus } \\
\text { for employees } \\
\text { ( } \% \text { of annual } \\
\text { wage) } \\
\text { [vii] }\end{array}$ & $\begin{array}{l}\text { Role of } \\
\text { auditor }\end{array}$ \\
\hline CL. & 25 & Net profit & 1 & 0 & 1 & + & 1 \\
\hline Cl. & 45 & Net profit & 1 & 1 & 1 & 16.0 & 0 \\
\hline Cl. & 48 & Operating profit & 0 & 0 & 0 & - & 1 \\
\hline CL. & 58 & Operating profit & 1 & 1 & 1 & 5.0 & 0 \\
\hline CL. & 60 & Net proft & 1 & 1 & 0 & 3.0 & 0 \\
\hline CL. & 65 & Profit & 0 & 0 & 0 & 30 & 0 \\
\hline a. & 70 & ROS & 1 & 1 & 1 & 10.0 & 1 \\
\hline Cl. & 80 & Net profit & 1 & 1 & 0 & 8.3 & 0 \\
\hline CL & 85 & Profit & 0 & 1 & 1 & 3.0 & 0 \\
\hline Cl. & 85 & Net profit & 0 & 0 & 0 & 18.0 & 0 \\
\hline CL & 90 & Operating profit & 0 & 0 & 0 & 2.3 & 0 \\
\hline $\mathrm{Cl}$ & 97 & Net profit & 0 & 0 & 0 & - & 0 \\
\hline Cl. & 118 & Operating profit & 1 & 1 & 1 & 2.7 & 0 \\
\hline $\mathrm{Cl}$ & 130 & ROI & 1 & 1 & 1 & 5.0 & 0 \\
\hline Cl. & 130 & Profit before taxes & 1 & 1 & 0 & 0.5 & 1 \\
\hline $\mathrm{Cl}$ & 130 & Proft before taxes & 0 & 1 & 1 & 0.9 & 0 \\
\hline CL. & 137 & ROI & 1 & 1 & 1 & 4.0 & 1 \\
\hline CL & 144 & Operating profit & 1 & 0 & 0 & 0.8 & 0 \\
\hline $\mathrm{CL}$ & 160 & Profit before taxes & 1 & 1 & 0 & 2.0 & 0 \\
\hline CL. & 170 & Profit & 0 & 0 & 0 & 10.0 & 0 \\
\hline $\mathrm{CL}$. & 183 & ROI & 1 & 1 & 0 & 7.5 & 0 \\
\hline $\mathrm{CL}$ & 220 & Operating profit & 1 & 0 & 1 & - & 0 \\
\hline CL. & 230 & Operating profit & 1 & 0 & 1 & - & 0 \\
\hline $\mathrm{CL}$ & 250 & Net profit & 0 & 0 & 0 & 12.5 & 1 \\
\hline $\mathrm{CL}$ & 260 & Operating results & 0 & 0 & 0 & - & 1 \\
\hline CL. & 335 & Operating profit & 0 & 1 & 1 & $=$ & 1 \\
\hline $\mathrm{Cl}$ & 350 & ROI & 1 & 1 & 0 & 6.3 & 1 \\
\hline $\mathrm{CL}$ & 350 & Net profit & 0 & 0 & 1 & $\therefore$ & 0 \\
\hline $\mathrm{CL}$ & 350 & ROE & 0 & 0 & 1 & 9.6 & 1 \\
\hline $\mathrm{CL}$ & 377 & ROS & 1 & 1 & 1 & - & 0 \\
\hline $\mathrm{CL}$ & 433 & $\mathrm{ROI}$ & 1 & 1 & 0 & 7.0 & 0 \\
\hline $\mathrm{CL}$ & 450 & Sales & 1 & 1 & n.c. & - & 0 \\
\hline $\mathrm{Cl}$ & 500 & ROI & 1 & 0 & 1 & 3.5 & 0 \\
\hline $\mathrm{CL}$ & 650 & Operating profit & 0 & 0 & 0 & 8.3 & 1 \\
\hline $\mathrm{CL}$ & 702 & Net profit & 1 & 0 & 1 & 3.0 & 0 \\
\hline $\mathrm{CL}$ & 720 & Net profit & 0 & 0 & 1 & - & 1 \\
\hline $\mathrm{Cl}$ & 730 & $\mathrm{ROI}$ & 1 & 1 & 1 & 4.0 & 1 \\
\hline $\mathrm{CL}$ & 780 & Operating profit & 0 & n.c. & 0 & - & 0 \\
\hline $\mathrm{CL}$ & 800 & Operating profit & 0 & 0 & 1 & $\therefore$ & 0 \\
\hline $\mathrm{Cl}$ & 1,180 & ROI & 1 & 0 & 0 & 2.5 & 0 \\
\hline $\mathrm{CL}$ & 1.250 & Operating profit & 1 & 1 & 0 & 0.9 & 0 \\
\hline $\mathrm{CL}$ & 1,300 & Operating profit & 0 & 0 & 0 & - & 1 \\
\hline $\mathrm{CL}$ & 1,400 & Profit & 0 & 0 & 0 & 4.2 & 0 \\
\hline $\mathrm{CL}$ & 1,450 & Net profit & 1 & 0 & 1 & 1.0 & 0 \\
\hline $\mathrm{CL}$ & 1.875 & Operating profit & 1 & 1 & 1 & 4.0 & 0 \\
\hline $\mathrm{CL}$ & 2,200 & ROS & 1 & 0 & 0 & $\cdot$ & 0 \\
\hline $\mathrm{CL}$ & 2.600 & Operating profit & 0 & 0 & 0 & $\therefore$ & 0 \\
\hline $\mathrm{CL}$ & 2,850 & Operating profit & 1 & 1 & 0 & 3.3 & 0 \\
\hline $\mathrm{CL}$ & 3.000 & Operating profit & 0 & 0 & 1 & - & 1 \\
\hline CL & 3.233 & Operating profit & 1 & 1 & 1 & . & 1 \\
\hline
\end{tabular}

$0=1$ 0; $1=$ yes, CL. EPSP = comorate-level EPSP. IL-EPSP = industry-level EPSP; EPS: eamings per share; $n$. ROE = profivequity, $R O A=$ profittotal assets, $R O S=$ profitsales; $\approx=$ for calculating the relative bonus, in four cases the absolute bonus is divided by an estimated mean annual wage of EURO 30,000 . 
Table 4.6 : Part 2: The parameters of EPSPs in CBCs in $1999(\mathrm{~N}=63)$.

\begin{tabular}{|c|c|c|c|c|c|c|c|}
\hline $\begin{array}{l}\mathrm{CL} \text { - } \\
\text { or } \\
\text { il. } \\
\text { EPSP } \\
\text { 0. }\end{array}$ & $\begin{array}{l}\text { Number of } \\
\text { employees } \\
\text { covered by } \\
\text { the EPSP } \\
\text { [i] }\end{array}$ & Bonus driver & $\begin{array}{c}\text { Lower } \\
\text { boundary } \\
>0\end{array}$ & $\begin{array}{c}\text { Upper } \\
\text { boundary } \\
\text { [v] }\end{array}$ & $\begin{array}{l}\text { Bonus driver } \\
\text { adjusted } \\
\text { before bonus } \\
\text { is determined } \\
\text { [vi] }\end{array}$ & $\begin{array}{c}\text { Maximum bonus } \\
\text { for employees } \\
\text { (\% of annual } \\
\text { wage })^{4} \\
\text { [vii] }\end{array}$ & $\begin{array}{l}\text { Role of } \\
\text { auditor }\end{array}$ \\
\hline CL & 3.469 & Operating profit & 1 & 1 & 0 & 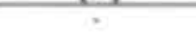 & 0 \\
\hline al & 4,100 & Profit & 1 & 0 & 1 & . & 0 \\
\hline $\mathrm{Cl}$ & 5,225 & Profit & 0 & 0 & 0 & 12.0 & 0 \\
\hline cl & 7,500 & ROS & 0 & 1 & 0 & 9.0 & 1 \\
\hline $\mathrm{Cl}$ & 7.800 & ROI & 1 & 1 & 0 & 70 & 0 \\
\hline $\mathrm{Cl}$ & 11,300 & Operating profit & 0 & 0 & 1 & > & 0 \\
\hline Cl. & 13,500 & Operating profit & 0 & 0 & 1 & 4.0 & 0 \\
\hline $\mathrm{Cl}$ & 35.500 & ROS & 1 & 1 & 0 & 3.0 & 0 \\
\hline n & 3,300 & Operating profit & 0 & 0 & 0 & . & 1 \\
\hline in. & 4,000 & Profit & 0 & 0 & 0 & . & 1 \\
\hline UL & 5,500 & Operating profit & 0 & 0 & 0 & . & 1 \\
\hline $\mathrm{l}$ & 6,945 & Net profit & 0 & 0 & 0 & . & 0 \\
\hline II. & n.c. & Profit & 0 & 0 & 0 & 2.0 & 1 \\
\hline $\begin{array}{l}N \\
(\mathcal{N})\end{array}$ & & & $\begin{array}{c}33 \\
(0.52)\end{array}$ & $\begin{array}{c}27 \\
(0.43)\end{array}$ & $\begin{array}{c}27 \\
(0.43)\end{array}$ & $\begin{array}{c}38 \\
(0.60)\end{array}$ & $\begin{array}{c}21 \\
(0.33)\end{array}$ \\
\hline
\end{tabular}

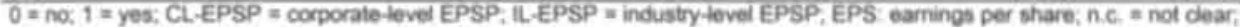
ROE = profitequity; ROI = profittotal assets; ROS = profitsales; $\mathbf{z}=$ for calculating the relative bonus, in four cases the absolute bonus is divided by an estimated mean annual wage of EURO 30,000 .

Table 4.6 reveals that the bonus driver is typically (operating) profit or a relative, profit-based performance indicator (see Table 4.6, column [iii]). Of the EPSPs, 52.4\% contain a lower boundary (see Table 4.6 , column [iv]) and $42.9 \%$ contain an upper boundary (see Table 4.6, column [v]). In the first scenario, employees receive a bonus only if profit exceeds a certain amount. In the second scenario, the bonus does not increase when profits exceed some other amount.

Figure 4.1 below illustrates an EPSP with a lower and upper boundary. The numbers between parentheses refer to the columns of Table 4.6.

In $42.9 \%$ of the EPSPs (see Table 4.6 , column [vi]), profit is adjusted before the amount of the bonus is determined, as in Example 4.3. In $60.3 \%$ of the EPSPs, the maximum bonus employees possibly can receive is mentioned (see Table 4.6, column [vii]). In $78.9 \%$ of the EPSPs where a maximum is mentioned, the bonus is $8.3 \%$ of the employees' annual wage or less (this equals approximately a one month's salary). The observed range of the maximum bonus runs from $0.5 \%$ to $18 \%$ of the annual wage, while the average maximum bonus is $5.4 \%$ of the annual wage (see Table 4.6 , column [vii]). In $39.7 \%$ of the EPSPs, the bonus is not explicitly maximised at the level of an individual employee (see Table 4.6, column [vii]). Finally, one third of the EPSPs refer to an auditor (see Table 4.6, column [viii]). 
Figure 4.1: An EPSP with a lower and upper boundary (the numbers between parentheses refer to the columns of Table 4.6).

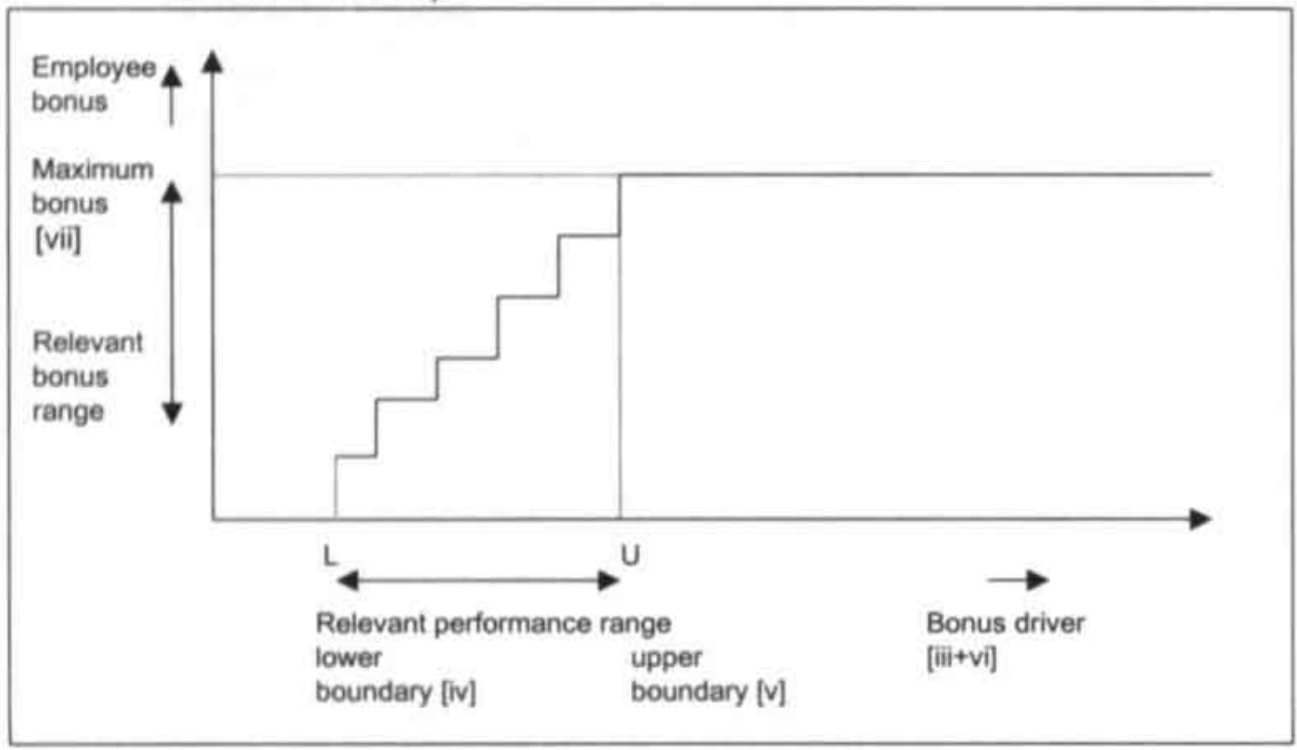

Example 4.7 illustrates the step-wise positive relation between the bonus driver ("ROF") and the employee bonus. The bonus increases step-wise and only when ROI is between the lower and upper boundary.

Example 4.7: CBC of DSM Resins B.V.25

\begin{tabular}{llll}
$\frac{\mathrm{ROI}}{<5.0 \%}$ & \multicolumn{3}{c}{ Bonus or days off } \\
\cline { 2 - 2 } & $0 \%$ & or - & \\
$>5.0 \%<7.5 \%$ & $1 \%$ & or 2.5 & days \\
$>1.5 \%<10.0 \%$ & $2 \%$ & or 5.0 & days \\
$>10.0 \%<12.5 \%$ & $3 \%$ & or 7.5 & days \\
$>15.5 \%<15.0 \%$ & $4 \%$ & or 10.0 & days \\
$>15.0 \%$ & $5 \%$ & or 12.5 & days
\end{tabular}

" (...) the bonus is determined in relation to the employees' annual wage. The company's performance is defined as operating profit as percentage of total assets of the division Harsen, as reported in the annual report of DSM N.V."

\subsubsection{Cross-sectional results}

Below we investigate whether the parameters of the EPSPs observed are associated with bargaining level. Therefore, the focus is on the distinction between CL-EPSPs and IL-EPSPs. As indicated, the sample of 63 EPSPs includes 58 CL-EPSPs and 5 IL-EPSPs, which are EPSPs applicable to employees across companies within a 
certain industry. IL-EPSPs appear more general in nature compared to CL-EPSPs. Table 4.6 makes clear that none of the 5 IL-EPSPs contains a lower (CL-EPSPs: $56.9 \%$ ) or an upper boundary (CL-EPSPs: $46.6 \%$ ) and the bonus driver is never adjusted before the bonus is determined (CL-EPSPs: $46.6 \%$ ), as opposed to the CLEPSPs. Another interesting finding is that $80 \%$ ( 4 out of 5 ) of the IL-EPSPs mention an auditor, versus only $29.3 \%$ of the CL-EPSPs. ${ }^{26}$

\subsubsection{Concluding remarks}

Because of the small number of IL-EPSPs, the cross-sectional results should be regarded as tentative. Keeping this in mind, and based on the differences in percentages, the following tentative conclusions can be drawn. Presumably, because CL-EPSPs are tailor-made, CL-EPSPs are defined in more detail than are IL-EPSPs. Consequently, accounting plays a more important role in CL-EPSPs than in ILEPSPs. Opposite results are found with regard to the role of auditing in CL-EPSPs and IL-EPSPs. Auditing more often plays a role in IL-EPSPs than in CL-EPSPs, and also the role is different. In CL-EPSPs, auditors typically audit the bonus driver, while in IL-EPSPs auditors typically determine whether there is room for a bonus, as is illustrated in Example 4.4. In IL-EPSPs, the judgement of auditors is an alternative for defining the EPSPs in more detail. One possible explanation is that in the absence of a tailor-made EPSP, some authority is delegated to the auditor, who as an independent third party can take into account the particulars (e.g. ability to pay, earnings trend, positioning versus competitors) of the bonus paying company in the industry.

\subsection{Summary and overall conclusions}

This chapter addresses the research question: What is the role of accounting and auditing in CBCs and EPSPs, and what explains the variation of this role? To answer this question, we investigated and compared the roles of accounting and auditing in Dutch CBCs and EPSPs in the profit sector in 1999 and 1992 . Two detailed research questions and two hypothesis are presented. The results are summarised in Table 4.7. 
Table 4.7: Summary of the test results.

\begin{tabular}{|c|c|c|c|}
\hline \multicolumn{2}{|c|}{ Research question / hypothesis } & \multirow{2}{*}{$\begin{array}{l}\text { Results } \\
\text { To define EPSPs. }\end{array}$} & \multirow{2}{*}{$\frac{\text { Table }}{4.2}$} \\
\hline RQ1 & What is the role of accounting in CBCs? & & \\
\hline RQ2 & What is the role of auditing in CBCs? & $\begin{array}{l}\text { To audit the bonus driver (profit number) } \\
\text { and to indicate whether profits allow a } \\
\text { bonus reward. }\end{array}$ & 4.3 \\
\hline$\overline{\mathrm{H} 1}$ & $\begin{array}{l}\text { CL-contracts more often contain } \\
\text { accounting information than } \\
\text { IL-contracts. }\end{array}$ & Supported. & 4.4 \\
\hline H2 & $\begin{array}{l}\mathrm{CL} \text {-contracts more often refer to } \\
\text { auditing than IL-contracts. }\end{array}$ & $\begin{array}{l}\text { Not supported, though difference in } \\
\text { expected direction. }\end{array}$ & 4.5 \\
\hline
\end{tabular}

$\overline{\mathrm{CBC}}=$ collective bargaining contract; $\mathrm{EPSP}=$ employee profit sharing plan; $\mathrm{CL}$-contract $=$ corporate-level contract; IL-contract $=$ industry-level contract.

We found that of the 1,332 CBCs studied, $104(7.8 \%)$ contain accounting information. In 1999, CBCs contain accounting information slightly more often than in $1992(8.7 \%$ versus $6.8 \%$ ); however, this difference is not statistically significant. Of the 1,332 CBCs, 33 CBCs $(2.7 \%)$ refer to auditing. In 1999, CBCs refer to auditing slightly more often than in $1992(2.9 \%$ versus $2.0 \%)$; here as well the difference is not statistically significant. The role of auditors in CBCs in 1999 and 1992 appears to be twofold: to audit annual accounts on which the employee bonus is based, and to decide whether reported profits provide room for a bonus. The analysis makes clear that accounting and auditing only play a role in CBCs in the context of EPSPs. So, the variation in the role of accounting information and of auditing in CBCs depends on the occurrence of EPSPs in CBCs.

This chapter uses the research methodology of content analysis to study the parameters of 63 EPSPs effective in 1999. We found that some EPSPs have a (stepwise) positive relation between the bonus driver and employee bonus, and that many EPSPs contain a lower boundary and/or an upper boundary. EPSPs do not restrict financial accounting policies, such as the choice of accounting methods. Furthermore, such items as (operating) profit are pretty loosely defined. The data indicate a number of differences between the parameters of CL-EPSPs and IL-EPSPs. CL-EPSPs are defined in more detail. Furthermore, auditors more often play a role in IL-EPSPs and they play a different role than they do in CL-EPSPs. In IL-EPSPs, auditors determine whether reported profit allows a bonus reward, while in CL-EPSPs auditors typically audit the bonus driver (e.g. reported profit). The difference can be explained by the fit of the EPSP to the companies involved. IL-EPSPs are more general in nature and pretty loosely defined, making the role of the auditor as independent third party more important. Note that because of the sample size, no formal test is performed to determine whether differences are statistically significant.

How do these findings relate to previous research as discussed in Section 4.3? The 
first link is to research in contracting. US, UK and Australian evidence showed that accounting information plays a role in debt contracts and executive wage contracts. The reason accounting information is included in these contracts is to define the relation between the future performance of the company and the distribution of cash flows among stakeholders of the company. We find comparable evidence for the use of accounting information in EPSPs in CBCs. The second link is to research on the demand for accounting information by trade unions. This chapter adds to that literature because whenever trade union bargainers agree upon EPSPs, they are likely to demand accounting information to see whether the employee bonus is determined according to the contractual arrangements. The third link is to research on the role of auditing in contracting. This chapter adds to that literature because empirical evidence is presented on the role of auditing in non-executive employee contracts. The fourth link is to the earnings management literature. This chapter finds that in some CBCs there is a direct relation between reported profit and the distribution of cash flows to non-executive employees. Depending on the specific circumstances, such contracts may affect the likelihood of earnings management. ${ }^{27}$

Research opportunities following from this chapter will be discussed in Chapter 8 . 


\section{Appendix 4A: Summary of EPSPs studied}

Table 4.9: Summary of EPSPs studied.

\begin{tabular}{|c|c|}
\hline AAR Allen Airmotive & Isover \\
\hline Aero Groundservices & Jamin Winkelbedrijf \\
\hline Air Treads Aircraft & Koninklijke PTT Nederland \\
\hline Akzo Nobel Chemicals & Lucent Technologies Network Systems \\
\hline AlliedSignalFluorochemicals & Naco Ferries \\
\hline Amev & Nederlandsche Apparatenfabriek Nedap \\
\hline Arcadis Heidemij & Neste Resins \\
\hline Bedriffsservices Barneveld & Norit \\
\hline Berghuizer Papier & NPBI International \\
\hline Bull & Vereenigde Glasfabrieken \\
\hline Coca Cola & Océ \\
\hline Codi International & Optische Industrie Enot \\
\hline Cookson Matthey & Plasma Optimal Fibre \\
\hline CSM Suiker & Plateelbakkerij \\
\hline Deift Gelatine & Plukon \\
\hline Depron (Hoechst Holland) & PodtAlplain Beheer \\
\hline Drankindustrie/groothandel in dranken & Porceleyne Fles \\
\hline DSM Engineering Plastics & PPG Industries Fiber Glass \\
\hline DSM Fine Chemicals & Reed Elsevier \\
\hline DSM Limburg & Reesink \\
\hline DSM Special products & Rubber-en Kunststoffenindustrie \\
\hline Enna Aerosois & Schur Flexible Benelux \\
\hline GAK Groep & SFB-groep \\
\hline Gelderse Papier & Suikerunie \\
\hline Genencor International & Talens \\
\hline Golfkarton de Zeeuw & Trobas \\
\hline Graanbe- en verwerkende industrie & Ubbink \\
\hline Groothandel in textiel & Wolters Kluwer \\
\hline GTI & Zeepfabriek De Nieuwe Fenix \\
\hline Heineken & Zeilmakerijen etc. \\
\hline Hoogovens & Zuid-Chemie \\
\hline IKEA Nederland & \\
\hline
\end{tabular}
$\mathrm{N}=63$; All EPSPs effective in 1999. 


\section{Notes}

1. The author wishes to thank Laury Bollen for comments on an earlier version of this chapter. He also wishes to thank Yvonne Schols and three students, Paul van der Aa, Miriam Janssen and Rogier van Wijk for their research assistance. A paper based on this chapter was published in the European Accounting Review (Hassink, 2000).

2. EPSPs typically specify the relation between a company's reported profit and the bonus reward for non-executive employees. EPSPs provide employees with an addition to their wage. For employers, profit sharing can help to motivate employees, and it provides a flexible way of rewarding employees.

3. A more elaborate discussion of the theoretical framework underlying the usefulness of accounting and auditing to trade unions in the setting of collective wage bargaining is provided in Chapter 2 of this dissertation.

4. See also Watts and Zimmerman (1986, p.189).

5. The role of accounting information in debt contracts is studied in the United States (Castle [1980], Leftwich [1983], and Press and Weintrop [1990]), in the United Kingdom (Citron, 1992) and Australia (Zimmer [1986], Stokes and Leong [1988], and Ramsay and Sidhu [1998]). The role of accounting information in executive wage contracts is studied in the United States (e.g. Healy, 1985).

6. Note that studying EPSPs is not new. Bougen (1988) presented a UK-based case study on profit sharing; however, the focus was not on wage contracts. Oakes and Covaleski (1998) presented three case studies on gain sharing in the $1950 \mathrm{~s}$ and $1960 \mathrm{~s}$ in the US. Both studies are case-oriented, while the current study explores a sample of EPSPs.

7. This role has received a great deal of attention in (positive) accounting literature. See for instance Antle (1982), Leftwich (1983), Dassen (1989), DeAngelo (1990).

8. In the United States, Goggans (1964) and Frank and Talwar (1988) reviewed the role of the external auditor in collective wage bargaining. In the Netherlands, Kok (1975a and 1975b) and Schilder (1994a and 1994b) discussed it, although not from an empirical angle. The possible role of the (management) accountant in employee contracting has received some attention in the United Kingdom (Craft, 1981) and Canada (Amernic, 1989).

9. These contracts may be either explicit (e.g. managers' compensation plans [e.g. Healy, 1985] or debt contracts [e.g. Dhaliwal, 1980]) or implicit (e.g political contracts [e.g. Cahan, 1992]). For an overview of this and related lines of research see Watts and Zimmerman (1986 and 1990) and Ball and Smith (1992). 
10. Studies on the impact of collective wage bargaining on managerial accounting decisions include Liberty and Zimmerman (1986), Yamaji (1986), DeAngelo and DeAngelo (1991), Mautz and Richardsen (1992), Waterhouse et al. (1993), Cullinan and Knoblett (1994).

11. See for instance Van Voorden et. al (1993, p.243).

12. See for instance Van Voorden et. al (1993, p.243).

13. For the purpose of this study, the profit sector is defined as companies and industries with SBI-codes starting with $0,1,2,3,5,6,7,8$ and the not-for-profit sector is defined as organisations and industries with SBI-codes starting with 4 or 9.

14. For the purpose of this chapter, accounting information is defined as quantitative information that is related to a company or an industry's financial performance or financial position. Examples of accounting information, as defined in this chapter, include: (net) sales, (net and operating) profit, equity etc.

15. Dutch accounting legislation distinguishes two types of auditors: "registered accountants" (registeraccountants, or RAs) and "accountants and administrative consultants" (accountant-administratieconsulenten or AAs). RAs and some AAs are allowed to conduct statutory audits. RAs mainly operate in large and medium sized companies, while AAs typically focus on small and medium sized companies. The latter typically provide management advisory services. In the current chapter, the role of both types of auditors, working either as external or internal auditor, will be investigated. For more on these two types of auditors see also Dijksma and Hoogendoom (1993, p.13), Buijink and Eken (1999) and Appendix A at the end of this dissertation.

16. CBC of Koninklijke PTT Nederland N.V., effective: 1-1-1997/12-31-1999; translated into English.

17. CBC of the Groothandel in Textiel en Aamverwante Artikelen, effective: 1-4-1998/12-311999; translated into English.

18. CBC of N.V. Nederlandsche Apparatenfabriek Nedap, effective: 4-1-1998/3-31-1999; translated into English.

19. CBC of Rubber-en Kunststofindustrie, effective: 7-1-1997/3-31-1999; translated into English.

20. CBC of CSM Suiker B. V., effective: 4-1-1998/3-31-2000; translated into English.

21. CBC of DSM Fine Chemicals B.V., effective: 4-1-1998/3-31-2000; translated into 
English.

22. For a general introduction into the research methodology of content analysis see Berelson (1971), Krippendorff (1980), and Weber (1985). An example of the use of content analysis in accounting research is Green et al. (1998). For a discussion of the possibilities and limits of content analysis see Harris (1996).

23. For instance, the bonus variable is defined as net profit excluding the profits from subsidiaries, or excluding the effect of depreciation. See also Example 4.3.

24. This was calculated as: $(327 / 378)^{\bullet} 100 \%$.

25. CBC of DSM Resins B.V., effective: 4-1-1997/3-31-1999; translated into English.

26. We did not conduct chi-square tests because this is not appropriate if more than $20 \%$ of categories contain less than five observations, which is the case here. Pooling data is not a solution either, since the crosstab concerned already has a two by two format. See Siegel and Castellan (1988, p.49).

27. See Hassink (2000, pp.278-279) for more on the likelihood of earnings management in this setting. 


\section{Chapter 5}

\section{The Use and Perceived Importance of Corporate Annual Reports: A study among trade union bargainers}

\subsection{Introduction}

This chapter presents the results of a survey among trade union bargainers on the use and perceived importance of accounting information, focusing in particular on corporate annual reports (CARs). The setting is that of collective wage bargaining.' The aim of this chapter is (1) to investigate whether trade union bargainers use CARs, (2) to investigate the perceived importance of CARs from the trade union bargainers' point of view, and (3) to investigate, also from the trade union bargainers' perspective, the perceived importance of the consolidated income statement. ${ }^{2}$

Chapter 2 provided theoretical arguments suggesting that CARs are potentially useful to trade union bargainers. Chapter 3 reviewed the existing empirical evidence in this respect. Existing Anglo-Saxon evidence indicates that accounting information is used by trade union bargainers in the setting of collective wage bargaining. The current chapter also complements Chapter 4 , which found that accounting information plays a role in collective bargaining contracts, especially in the design of employee profit sharing plans. The current chapter continues to investigate the use of accounting information; this time, however, the focus is not the use of accounting information in the outcome of collective wage bargaining (the contents of collective bargaining contracts), but on the use of accounting information in the collective wage bargaining process itself.

The central research question of this chapter is:

Do trade union bargainers use corporate annual reports and do they perceive corporate annual reports as important, and if so, what explains the variation in usage and perceived importance?

Again, the setting is the Netherlands. The empirical part of this chapter is composed of three parts. Each of the three parts addresses a research question split into a number of hypotheses. The research questions are the following: 
1. What is the use of corporate annual reports (USECAR) by trade union bargainers, and what explains the variation in usage? (Section 5.6)

2. What is the importance of corporate annual reports (IMPCAR) as perceived by trade union bargainers who use corporate annual reports, and what explains the variation in perceived importance? (Section 5.7)

3. What is the importance of the consolidated income statement (IMPCIS) as perceived by trade union bargainers who use corporate annual reports, and what explains the variation in perceived importance? (Section 5.8)

The plan of this chapter is as follows. Section 5.2 presents the theoretical framework. Section 5.3 sketches the relations to previous empirical research. Section 5.4 develops the hypotheses. Section 5.5 summarises the research method and discusses the characteristics of the respondents. Sections 5.6 to 5.8 present the empirical results. Finally, Section 5.9 provides a summary and overall conclusions.

Table 5.1 shows how the empirical part of the chapter is composed.

Table 5.1: The composition of the empirical part of this chapter.

\begin{tabular}{llc}
\hline Dependent variable & Analysis & Section \\
\hline Use of CARs (USECAR) & univariate & 5.6 .2 \\
& multivariate & 5.6 .3 \\
\hline Importance of CARs (IMPCAR) & univariate & 5.7 .2 \\
& multivariate & 5.7 .3 \\
\hline Importance of CIS (IMPCIS) & univariate & 5.8 .2 \\
& multivariate & 5.8 .3 \\
\hline
\end{tabular}

CAR: corporate annual report; CIS: consolidated income statement.

\section{2}

\section{Theoretical framework}

As was explained in chapter 2 in detail, from a contracting cost perspective, accounting information may serve as an input in contractual decision making in the setting of collective wage bargaining. Since the position of trade unions depends on the support of their members, trade unions must assess employees' wage targets and resistance points. If these are based upon "how well the company is doing" accounting information concerning the performance of the company may well be used by trade unions.

Previous studies found that stakeholders and their representatives use CARs for general orientation and for specific decision making.' We believe trade union bargainers are no exception to this. Trade union bargainers potentially use CARs for general orientation - to get an overall impression of the company and to learn about threats to and opportunities for employees. ${ }^{4}$ Trade union bargainers also potentially 
use CARs for making decisions about wage claims. The idea here is that the wage claim for employees of company i depends on company i's ability to pay, which in turn is determined by the company's performance. The performance is measured and reported in the CAR of company $i$. Therefore, CARs are potentially used by trade union bargainers.

Furthermore, consolidated income statements are likely to be of importance to trade union bargainers as well, since these statements measure the performance of the companies involved, by presenting the profit figures and their components.

\subsection{Relations to previous empirical research}

This chapter builds on two sets of previous research. The first set of studies deals with the use of accounting information by trade unions' and the consequent effect on the process and outcome of collective wage bargaining. ${ }^{\circ}$ Chapter 3 of this dissertation provides an overview of these studies.

The second set, not reviewed in Chapter 3, examines the use of CARs by shareholders, corporate lenders and investment analysts. Most of this research has been conducted in the Anglo-Saxon countries. ${ }^{7}$ Klaassen and Schreuder (1980, Chapter 1), Griffin (1987) and Vergoossen (1993) provide research overviews. A more recent overview is provided by Martinez Ramos (2000).

In the Netherlands, three comparable studies on the use of CARs have been conducted.

Klaassen and Schreuder (1980) examined the use of CARs by shareholders, managers, staff employees, investment analysts and members of works councils. Of the respondents, $85.3 \%$ indicated using CARs for the purpose of general orientation, and $11.9 \%$ indicated using CARs for a specific decision. ${ }^{*}$ The consolidated income statement is the most important section of CARs; $88.9 \%$ of the respondents consider this section (very) important. This is consistent across the different groups of respondents, except for staff employees who consider the consolidated balance sheet slightly more important.

Vergoossen (1993) studied the use and perceived importance of CARs by investment analysts. He found that $85.4 \%$ of the investment analysts use CARs. Of the analysts who are involved in company analysis, $98.7 \%$ indicated the use of CARs. Of the ten information sources suggested, the most recent CAR was ranked highest, with $90.3 \%$ of the users indicating it as a (very) important information source. Within CARs, the consolidated income statement is regarded as most important; $94.4 \%$ of the users of 
CARs ranked it as (very) important.

Bollen (1996) investigated the use and usefulness of CARs of small and medium-sized companies to loan officers. He found that $97.5 \%$ use CARs in making loan decisions. Among seven suggested information sources potentially relevant in specific loan decisions, CARs are perceived as most important. Over $80 \%$ of the respondents consider CARs a (very) important information source, with a mean score of 4.73 on a scale running from 1 (unimportant) to 5 (very important). Looking at elements of CARs, the income statement is ranked as most important, with a mean score of 4.88 . A number of significant relations were also found between the perceptions of the respondents and their personal characteristics.

The empirical findings of these three studies are summarised in Table 5,2.

Table: 5.2: Summary of previous empirical research in the Netherlands on the use of CARs.

\begin{tabular}{|c|c|c|c|c|c|c|}
\hline Study & Subjects & $\mathbf{N}$ & $\begin{array}{l}\text { Response } \\
\text { rate } \\
\text { in } \%\end{array}$ & $\begin{array}{l}\text { Use of } \\
\text { CARs } \\
\text { in } \%\end{array}$ & $\begin{array}{l}\text { Imp. of CARs } \\
\text { [\%(very) imp] } \\
\text { \{mean\} }\end{array}$ & $\begin{array}{l}\text { Imp. of CIS } \\
\text { [\%(very) imp] } \\
\text { \{mean\} }\end{array}$ \\
\hline \multirow{6}{*}{$\begin{array}{l}\text { Klaassen } \\
\text { and } \\
\text { Schreuder } \\
(1980)\end{array}$} & Shareholders & 175 & n.r. & n.r. & n.r. & [94.3] \\
\hline & Directors & 80 & n.r. & n.r. & n.r. & [78.3] \\
\hline & Staff employees & 66 & n.r. & n.r. & n.r. & [81.8] \\
\hline & Investment advisors & 40 & n.r. & n.r. & n.r. & {$[94.4]$} \\
\hline & Members works council & 27 & n.r. & n.r. & n.r. & [89.5] \\
\hline & Total & $640^{\circ}$ & 16.8 & n.r. & n.r. & $\begin{array}{l}{[88.9]} \\
\{4.39\}\end{array}$ \\
\hline $\begin{array}{l}\text { Vergoossen } \\
\text { (1993) }\end{array}$ & Investment analysts & 205 & 51.8 & 85.4 & $\begin{array}{l}{[90.3]} \\
\{4.59\}\end{array}$ & $\begin{array}{l}{[94.2]} \\
\{4.67\}\end{array}$ \\
\hline $\begin{array}{l}\text { Bollen } \\
\text { (1996) }\end{array}$ & Loan officers & 80 & 42.6 & 97.5 & $\begin{array}{l}{[80.0]} \\
\{4.73\}\end{array}$ & $\{4.88\}^{b}$ \\
\hline
\end{tabular}

a: 252 respondents had either another relation to the company whose CAR was used, or they did not answer this question; b: Bollen only investigated the importance of the income statement and not of the consolidated income statement: Imp: importance; scale 1-5: 1=unimportant: 5=very important; CIS: consolidated income statement, imp: important; n.r.; not reported.

The three Dutch studies confirm the results of the Anglo-Saxon studies. First, CARs are used by a diverse set of users in the financial arena. Second, CARs are a relatively important source of information. Third, the consolidated income statement is regarded as a (very) important segment of CARs.

Given these empirical facts, this chapter aims to add to the literature by shedding light on the use and importance of (segments of) CARs as perceived by another group of potential users: trade union bargainers. 
Development of the hypotheses

\subsubsection{The dependent variables}

As indicated, the approach of the empirical part is threefold. The three research questions proposed in Section 5.1 present three dependent variables. The variation of these variables will be investigated in succession. First, we will investigate what determines whether trade union bargainers use CARs in collective wage bargaining $(\mathrm{N}=101)$.

Then we will go one step further, and limit the analysis to those bargainers who indicated that they use CARs $(\mathrm{N}=84)$. It will be seen that within this subgroup there is variation as to the perceived importance of CARs. We will investigate this variation.

Then again we will go one step further. In Chapter 2 and in Section 5.2, it was argued that reported profit numbers are potentially relevant to trade union bargainers. Within CARs, information about profit and its composition can be found in the income statement. Previous research among CAR users found that the income statement is perceived as most important, and that the consolidated income statement is perceived as more important than the parent company income statement. Therefore, the third part of the analysis investigates the variation in the perceived importance of the consolidated income statement $(\mathrm{N}=84)$.

\subsubsection{The independent variables}

The variation of the dependent variables will be studied by focusing on the explanatory power of the variable "bargaining level". In addition, we will investigate the power of five control variables, to test whether the variation in the dependent variables is due to other variables apart from bargaining level. The control variables are: (1) the importance of specific information in general orientation in collective wage bargaining, (2) the perceived importance of ability to pay as a justifying argument in making wage claim decisions, (3) trade union affiliation, (4) level of education of the trade union bargainer, and (5) length of tenure as a trade union bargainer.

\subsubsection{Hypothesis 1: the impact of bargaining level}

The dual collective wage bargaining system of the Netherlands is introduced in Chapter 1, summarised in Chapter 4 and discussed in more detail in Appendix B at the 
end of this dissertation. ${ }^{\circ}$ The role of CARs potentially differs in CL-bargaining and IL-bargaining. Given the need for tailor-made contracts at corporate-level versus the more general contracts at industry-level ${ }^{10}$, we expect that CARs are more important in CL-bargaining than in IL-bargaining. Therefore, we hypothesise that:

H1 USECAR, IMPCAR and IMPCIS are higher for CL-bargainers than for IL-bargainers (LEVEL).

\subsubsection{Hypothesis 2: the importance of company specific information}

This hypothesis results from the theoretical analysis in Chapter 2. The first stage of collective wage bargaining is that of general orientation. During this period trade union bargainers potentially use all kinds of information. We hypothesise that trade union bargainers who perceive company specific information to be more important in general orientation in collective wage bargaining, more often use CARs, and perceive (segments) of CARs to be more important as well. Therefore, we hypothesise:

H2 USECAR, IMPCAR and IMPCIS are positively related to the perceived importance of company specific information (IMPCI).

\subsubsection{Hypothesis 3: the importance of ability to pay}

This hypothesis also results from the theoretical analysis in Chapter 2 . In the second stage of collective wage bargaining, trade union bargainers make a specific wage claim decision. This decision is potentially driven by several variables, including changes in the cost of living, the unemployment rate, wage claims for comparable employees, and the company's ability to pay." As explained in detail in Chapter 2, CARs are potentially relevant for assessing a company's ability to pay. Therefore, we expect a positive relation between the perceived importance of ability to pay as a justifying argument in making wage claim decisions and the use and perceived importance of (segments) of CARs:

H3 USECAR, IMPCAR and IMPCIS are positively related to the perceived importance of ability to pay in making wage claims (IMPATP).

\subsubsection{Hypothesis 4: the impact of trade union affiliation}

The relation between trade union affiliation and the use and perceived importance of accounting information has not been studied before. ${ }^{12}$ The main Dutch trade unions (FNV, CNV, MHP) differ in several respects. Historically, the FNV and CNV are 
blue-collar unions, while the MHP is a white-collar union. ${ }^{3}$ The FNV is positioned on the left side of the trade union spectre, the MHP at the right, and the CNV holds a position in between. ${ }^{14}$ Compared to the FNV, the CNV is "more willing to co-operate, more consensus-seeking, less emotional and less anti-capitalistic" while the MHP is more pragmatically driven, and more consensus-seeking than the others. ${ }^{3}$ We hypothesise that some of the variation in the dependent variables can be explained by trade union affiliation. We expect FNV-bargainers to be most reluctant to use CARs in collective wage bargaining and to perceive CARs and the consolidated income statement as less important. MHP-bargainers are expected to use CARs most often in collective wage bargaining and to perceive CARs and the consolidated income statement as more important in comparison with FNV-bargainers. We expect that $\mathrm{CNV}$-bargainers hold a position in between.

H4 USECAR, IMPCAR and IMPCIS are related to trade union affiliation (TUA).

\subsubsection{Hypothesis 5: the impact of length of tenure as a trade union bargainer}

Previous research (e.g. Bollen, 1996, p.166) found that age and length of tenure as a professional (a loan officer) are related to the perceptions of CARs. Given the expected correlation between age and length of tenure as a trade union bargainer, and because we consider length of tenure a more interesting variable than age, we will investigate the explanatory power of length of tenure as a trade union bargainer. The magnitude of the impact of this variable, however, is unclear. Senior bargainers may have experienced that CARs are worth using, or they may have learned that CARs are without value in the setting of collective wage bargaining. The opinions of senior bargainers are especially important because they are rooted in practical experiences and senior bargainers typically shape trade union policy. Since we have no $a$ priori expectation about the direction of the impact, we hypothesise that:

H5 USECAR, IMPCAR and IMPCIS are related to length of tenure as a trade union bargainer (TEN).

\subsubsection{Hypothesis 6: the impact of bargainer education level}

Previous research (e.g. Bollen, 1996, p.166) found some evidence that education is related to the perceptions of the users of CARs. We will use this finding to explain the variation in the dependent variables. Since it takes a certain level of education to understand accounting issues, and since it takes a positive attitude to develop the ability to use CARs, we expect that more highly educated bargainers are more likely to understand CARs and to use CARs. They are also more likely to attend training 
programs if they lack knowledge to interpret CARs. ${ }^{16}$ We hypothesise that:

H6 USECAR, IMPCAR and IMPCIS are positively related to the education level of bargainers (EDUC).

\subsection{Research method and respondents' characteristics}

\subsubsection{Research method: questionnaire and sample}

This chapter is questionnaire-based. ${ }^{17}$ Two versions of the questionnaire were developed: a version for CL-bargainers and one for IL-bargainers. The two versions were identical, except that the CL-version introduced each question in the context of CL-bargaining, while the IL-version did the same in the context of IL-bargaining. The first part of the questionnaire investigated the use and perceived importance of (parts of) CARs. The second part focused on personal characteristics to obtain a profile of the respondents."

The questionnaire was composed of 28 questions, some of which were divided further. With regard to the closed questions, trade union bargainers were instructed to express their opinions on a five-point Likert-scale, arranged as follows: 1) unimportant, 2) slightly important, 3) moderately important, 4) important, 5) very important. There was an additional possibility to indicate "no opinion/unable to judge".

To increase the validity of the research instrument, the questionnaire was based on questionnaires used in previous studies among users of CARs (Klaassen and Schreuder [1980], Vergoossen [1993] and Bollen [1996]). The questionnaire was discussed in detail with three accounting researchers who had conducted similar studies among other users of CARs. To make sure that the questions were easy to understand, colleagues were asked for feedback. After modifications, the questionnaire was discussed with an experienced trade union bargainer who has been involved in collective wage bargaining for over 20 years. The relevant parts of the questionnaire are attached to this chapter as Appendix 5A.

To construct a sample of trade union officials involved in collective wage bargaining, four daily Dutch newspapers were screened for articles on CL-bargaining and ILbargaining in the profit sector. The target articles had to mention the names of the trade union bargainers. ${ }^{19}$ This search resulted in a sample of 168 trade union bargainers. Each bargainer in the sample received a covering letter, a questionnaire and a prepaid return envelope; 103 questionnaires were returned, of which 101 were usable. ${ }^{20}$ 
As is shown in Table 5.3 the response rate was $60.1 \%$. Compared to response rates of previous studies in this line of research, this is satisfactory."

Table 5.3: Response rate.

\begin{tabular}{lc}
\hline & Response rate \\
\hline Questionnaires mailed & 168 \\
Retumed and completed & 103 \\
Usable & 101 \\
Response rate & $101 / 168=0.601$ \\
\hline
\end{tabular}

Before the data can be used, some considerations of possible non-response bias are needed. The non-response bias is tested by comparing the answers of early respondents to those of late respondents (Moser and Kalton, 1986; Oppenheim, 1992. Hartmann, 1997). The test results can be found in Appendix 5B at the end of this chapter. No significant differences were found between early and late respondents, suggesting that the views of respondents are not expected to differ significantly from those of non-respondents. Given this, we expect no problem in generalising the results.

\subsubsection{Respondents' characteristics}

Table 5.4 summarises some of the characteristics of the respondents. Of the 101 respondents, $66(65.3 \%)$ are CL-bargainers and $35(34.7 \%)$ are IL-bargainers. CLbargainers perceive company specific information in collective wage bargaining as more important than IL-bargainers ( 3.93 versus 3.49 ), while ability to pay as a justifying argument in making wage claims is perceived as more important by $\mathrm{IL}$ bargainers compared to CL-bargainers ( 4.35 versus 3.78 ). Furthermore, 43 bargainers $(42.6 \%)$ are affiliated with the FNV, $31(30.7 \%)$ with the CNV, $22(21.8 \%)$ with the MHP, and $5(5.0 \%)$ with other trade unions. ${ }^{22}$ On average, the respondents have 8.0 years bargaining experience. Most of the respondents $(70.3 \%)$ have attended a school for higher education. Compared to CL-bargainers, IL-bargainers conclude fewer collective bargaining contracts a year (mean: 2.5 versus 5.4 ) but the number of employees covered by the contract is larger (mean: 57,800 versus 11,400 employees). 
Table 5.4: Respondents' characteristics.

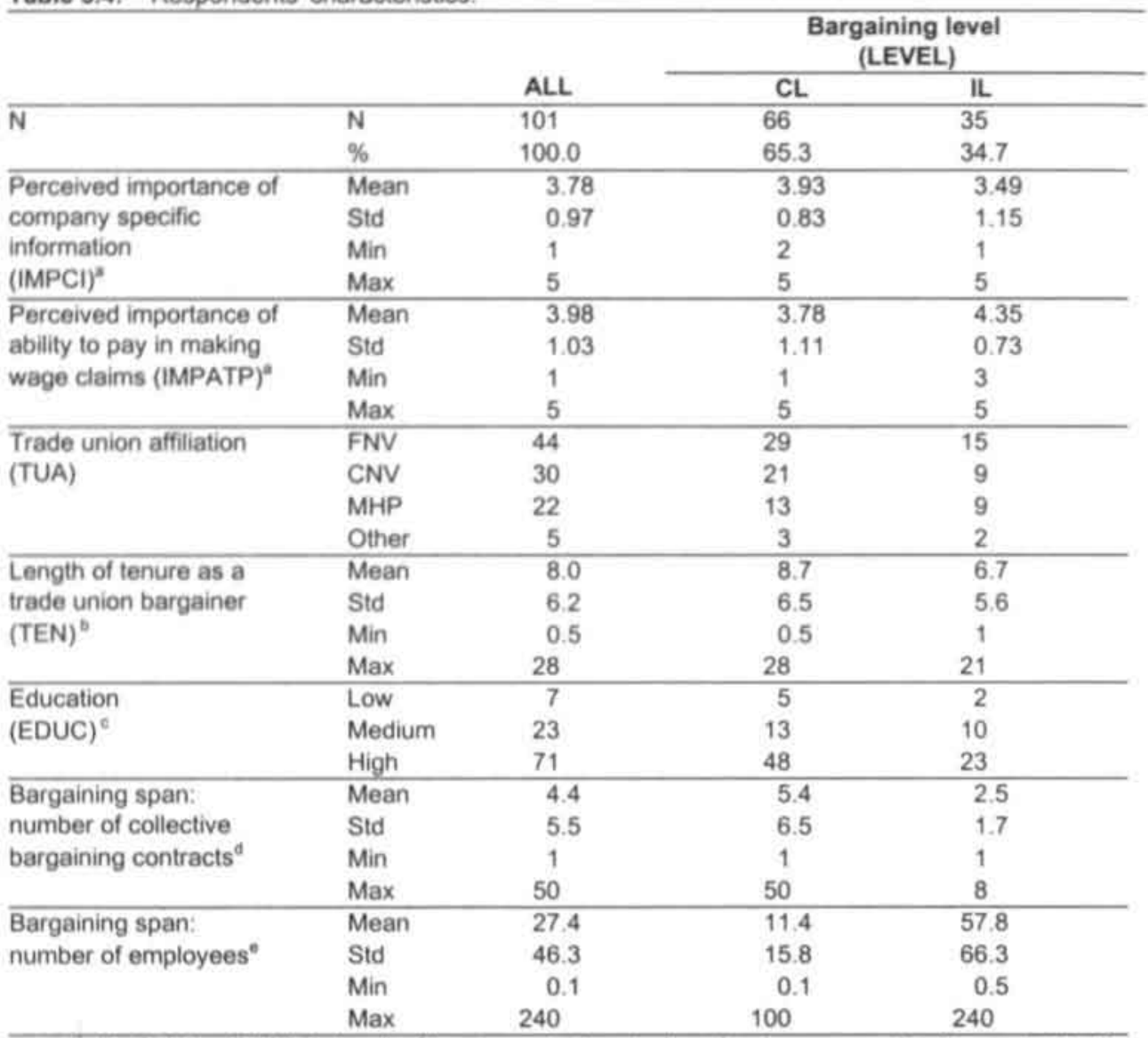

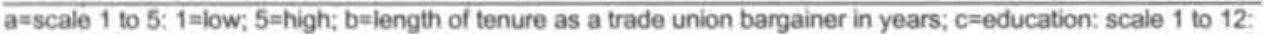
1-3=low; 4-8medium; 9-12=high; $d=i n$ contracts per year; $e=i n$ 1.000 employees per year; $C L$; corporate-level bargainers; IL: industry-level bargainers; FNV: Federatie Nederlandse Vakbeweging: CNV: Christelijk Nationaal Vakverbond; MHP: Vakcentrale for Middelbaar en Hoger Personeel.

The two variables related to bargaining span (number of collective bargaining contracts and number of employees, see Table 5.4) will not be used in the analysis below because these variables strongly correlate with the independent variable of main interest: bargaining level (CL-bargainers versus IL-bargainers). 


\subsection{The use of CARs: empirical results}

\subsubsection{The dependent variable: USECAR}

Of the 101 bargainers $84(83.2 \%)$ indicated the use of CARs. This is slightly less than reported by Vergoossen $(1994$, p.66) and clearly less compared with what Bollen (1996, p.155) found. Vergoossen found that $85.4 \%$ of the investment analysts use CARs in company analysis. Bollen (1996, p.155) found that $97.5 \%$ of the loan officers used CARs of medium-sized companies, either to get a general picture of a company's financial situation or as an input for a loan decision. Klaassen and Schreuder (1980) did not include this question in their questionnaire. Table 5.5 summarises the descriptive results.

Table 5.5: The use of CARs (USECAR): descriptive and univariate results.

\begin{tabular}{|c|c|c|c|c|c|c|c|}
\hline \multirow[t]{2}{*}{ Hypothesis } & \multirow[t]{2}{*}{ Subgroup } & \multirow[t]{2}{*}{$\mathbf{N}$} & \multicolumn{2}{|c|}{ Users } & \multicolumn{2}{|c|}{ Non-users } & \multirow{2}{*}{ Univariate results } \\
\hline & & & $\mathbf{N}$ & $\%$ & $\mathbf{N}$ & $\%$ & \\
\hline \multirow[t]{2}{*}{ H1: LEVEL } & $\mathrm{CL}$ & 66 & 57 & 86.4 & 9 & 13.6 & \multirow{2}{*}{$\begin{array}{l}\chi^{2} \text {-value: } 1.389 ; 1 d f ; \\
\text { sign. (1t): } 0.120 ; N=101\end{array}$} \\
\hline & IL & 35 & 27 & 77.1 & 8 & 22.9 & \\
\hline \multirow[t]{5}{*}{$\mathrm{H} 2$ : IMPCI } & 1 (low) & 4 & 1 & 25.0 & 3 & 75.0 & \multirow{5}{*}{$\begin{array}{l}\text { MW: } z \text {-score: }-1.563 ; \\
\text { sign. }(1 \mathrm{t}): 0.059 \\
\mathrm{~N}=100\end{array}$} \\
\hline & 2 & 11 & 6 & 54.5 & 5 & 45.5 & \\
\hline & 3 & 28 & 21 & 75.0 & 7 & 25.0 & \\
\hline & 4 & 42 & 41 & 97.6 & 1 & 2.4 & \\
\hline & 5 (high) & 15 & 14 & 93.3 & 1 & 6.7 & \\
\hline \multirow[t]{5}{*}{ H3: IMPATP } & 1 (low) & 3 & 3 & 100.0 & 0 & 0.0 & \multirow{5}{*}{$\begin{array}{l}\text { MW: } z \text {-score: } 0.550 \\
\text { sign. (1t): } 0.275 \\
N=97\end{array}$} \\
\hline & 2 & 6 & 5 & 83.3 & 1 & 16.7 & \\
\hline & 3 & 16 & 12 & 75.0 & 4 & 25.0 & \\
\hline & 4 & 37 & 33 & 89.1 & 4 & 10.8 & \\
\hline & 5 (high) & 35 & 27 & 77.1 & 8 & 22.9 & \\
\hline \multirow[t]{2}{*}{ H4: TUA } & FNV & 44 & 38 & 86.4 & 6 & 13.6 & \multirow{2}{*}{$\begin{array}{l}\chi^{2} \text {-value: } 0.569 ; 1 \mathrm{df} \\
\text { sign. (1t): } 0.226 ; \mathrm{N}=101\end{array}$} \\
\hline & Otherwise & 57 & 46 & 80.7 & 11 & 19.3 & \\
\hline \multirow[t]{3}{*}{ H5: TEN } & Low ( $<4$ years) & 26 & 24 & 92.3 & 2 & 7.7 & \multirow{3}{*}{$\begin{array}{l}\text { MW: z-score: }-0.569 \\
\text { sign. }(1 t): 0.285 \\
N=101\end{array}$} \\
\hline & Medium (4-8) & 40 & 33 & 82.5 & 7 & 17.5 & \\
\hline & High ( $>8$ years) & 35 & 27 & 77.1 & 8 & 22.9 & \\
\hline \multirow[t]{2}{*}{ H6: EDUC } & Low (level 1-8) & 30 & 22 & 73.3 & 8 & 26.7 & \multirow{2}{*}{$\begin{array}{l}\chi^{2} \text {-value: } 2.949 ; 1 \mathrm{df}, \\
\text { sign. (1t): } 0.043 ; \mathrm{N}=101\end{array}$} \\
\hline & High (level 9-12) & 71 & 62 & 87.3 & 9 & 12.7 & \\
\hline
\end{tabular}

$\chi^{2}=\chi^{2}$-test; MW: Mann-Whitney z-score; 1 t: 1-tailed; sign: significance level; df: degrees of freedom.

\subsubsection{Univariate results}

The dependent variable is dichotomous, as are the independent variables - bargaining level (corporate-level versus industry-level) and trade union affiliation (FNV versus otherwise). The independent variables of the perceived importance of company specific information, the perceived importance of ability to pay in making wage claims, and level of education, are ordinal scaled. Length of tenure as a trade union bargainer is interval scaled. We use the chi-square test for $\mathrm{H1}, \mathrm{H} 4$ and $\mathrm{H} 6$, and the 
Mann-Whitney U test for H2, $\mathrm{H} 3$ and $\mathrm{H} 5$.

Table 5.5 presents the univariate results. Note that for $\mathrm{H} 2$ and $\mathrm{H} 3$ the number of observations is less than 101. This is due to missing observations of the independent variables.

$\mathrm{H} 1$ focuses on the impact of bargaining level on the use of CARs. Of the CLbargainers, $57(86.4 \%)$ indicated the use of CARs, versus $27(77.1 \%)$ of the ILbargainers. Note that the use of CARs is quite high, also among the subgroup of ILbargainers. The difference is in the expected direction, though this is not significant. $\mathrm{HI}$ is not supported.

In $\mathrm{H} 2$ the relation between the importance of company specific information in general orientation in collective wage bargaining and the use of CARs is considered. The perceived importance of company specific information was measured on a five-point scale with an additional possibility to indicate "no opinion/unable to judge" (see Appendix 5A at the end of the chapter for details). Users of CARs consider company specific information in general orientation in collective wage bargaining more important than do non-users (mean: 3.77 versus 2.53 ). $\mathrm{H} 2$ is marginally supported.

In $\mathrm{H} 3$ the focus is on the relation between the perceived importance of ability to pay as a justifying argument in collective wage bargaining and the use of CARs by trade union bargainers. The perceived importance of ability to pay was measured on a fivepoint scale with an additional possibility to indicate "no opinion/unable to judge" (see Appendix 5A at the end of the chapter for details). There is no support for $\mathrm{H} 3$.

$\mathrm{H} 4$ focuses on the significance of trade union affiliation. To measure the independent variable, respondents were asked with which trade union federation they were currently affiliated. To decrease the number of categories and to increase the number of observations in the categories, trade union affiliation is treated as a dummy variable, taking the value 1 in the case of an FNV-bargainer and the value 0 otherwise. ${ }^{2}$ FNV-bargainers use CARs more often than do other trade union bargainers $(86.4 \%$ versus $80.7 \%$ ) The position of FNV-bargainers is not as hypothesised. The difference is not significant. H4 is not supported.

In H5 the focus is on length of tenure as a trade union bargainer. To measure the independent variable, respondents were asked to indicate how many years they have been working as a trade union bargainer. Less experienced trade union bargainers seem to use CARs more often than do more experienced bargainers. ${ }^{34}$ Still, the difference is not significant. H5 is not supported. 
H6 investigates the relation between the level of education and the use of CARs. To measure the independent variable, respondents were asked to indicate their level of education on a 12-point scale (see Appendix 5A at the end of the chapter for details). Highly educated trade union bargainers tend to use CARs more often. $\mathrm{H} 6$ is supported for conventional levels of significance.

Overall, the explanatory power of the individual variables is limited. One explanation is that the use of CARs is quite high $(83.2 \%)$ in combination with the sample size $(\mathrm{N}=101)$. This makes it difficult to identify independent variables that explain the variation in the use of CARs.

\subsubsection{Multivariate results}

This section investigates whether the combination of independent variables can explain the variation in the use of CARs. ${ }^{35}$ To test for the explanatory power of a combination of independent variables, a logistic regression model was estimated. Logistic regression is appropriate here because the dependent variable (USECAR) is either 1 (respondents who indicated the use of CARs in collective wage bargaining: $\mathrm{N}=84$ ) or 0 (respondents who indicated that they do not use CARs in collective wage bargaining: $\mathrm{N}=17){ }^{26}$ The following model was estimated:

USECAR $=\beta_{0}+\beta_{1} L E V E L+\beta_{2} I M P C I+\beta_{3} I M P A T P+\beta_{4} T U A+\beta_{5} T E N+\beta_{6} E D U C+\epsilon$

These variables are defined as follows:

USECAR: Use of CARs in collective wage bargaining ( $1=y e s ; 0=$ no)

LEVEL: $\quad$ Dummy variable indicating bargaining level ( $1=\mathrm{CL}$-bargaining, $0=\mathrm{IL}$-bargaining)

IMPCl: Perceived importance of company specific information in the stage of general orientation in collective wage bargaining (scale 1 to $5: 1=10$; $5=$ high)

IMPATP: Perceived importance of ability to pay as an argument in making wage claim decisions (scale 1 to $5: 1=$ low: $5=$ high)

TUA: Dummy variable indicating trade union affiliation ( $1=F N V, 0=0$ therwise)

TEN: $\quad$ Length of tenure as a trade union bargainer (in years)

EDUC: Level of education of the trade union bargainer (scale 1 to 12 : 1=low; 12=high)

Multicollinearity may be an obstacle for multivariate analysis. Multicollinearity can be detected by observing the associations between the independent variables. If one or both measures are dichotomous, the Cramér coefficient is the most appropriate measure of association (Siegel and Castellan, 1988, p.225). The Cramér coefficient has a maximum value of 1 , and $C$ equals 0 when the variables are independent. To analyse the relations between bargaining level and trade union affiliation, and between bargaining level and length of tenure as a trade union bargainer, the Cramér coefficient is calculated. To test for the association between length of tenure as a trade 
union bargainer and level of education, the Spearman-rank correlation test is used. All correlations are low to modest. Therefore, multicollinearity does not seem to pose a problem here.

Table 5.6: Correlation matrix ( $N=101)$.

\begin{tabular}{|c|c|c|c|c|c|}
\hline & LEVEL & IMPCI & IMPATP & TUA & TEN \\
\hline$\overline{\mathrm{IMPCI}}$ & $0.237[p=0.324]$ & & & & \\
\hline IMPATP & $0.272[p=0.205]$ & $0.184[p=0.105]$ & & & \\
\hline TUA & $0.011[p=0.917]$ & $0.353[p=0.588]$ & $0.381[p=0.478]$ & & \\
\hline TEN & $0.413[p=0.336]$ & $0.139[p=0.211]$ & $-0.064[p=0.571]$ & $0.462[p=0.261]$ & \\
\hline EDUC & $0.347[\mathrm{p}=0.341]$ & $0.039[\mathrm{p}=0.725]$ & $0.149[\mathrm{p}=0.189]$ & $0.434[p=0.150]$ & $-0.239[p=0.029]$ \\
\hline
\end{tabular}

LEVEL and TUA: Cramer's C coefficient of association; otherwise: Spearman correlation coefficient. LEVEL: $1=C L$. $0=1 \mathrm{~L} ;$ TUA: FNV=1, Otherwise $=0$; all p-values 2-tailed.

Table 5.7 summarises the results of the logistic regression. Only the parameter of the importance of company specific information is significantly different from zero, and in the expected direction. This suggests that those bargainers who believe company specific information plays a more important role in general orientation in collective wage bargaining, tend to use CARs more often. The other parameters are not significantly different from zero. Given a cut-off point of $0.5,81.3 \%$ of the observations are classified correctly. The model as a whole is not significant $\left(\chi^{2}\right.$-value: $5.177,6 \mathrm{df}$, sign.: 0.521).

Table 5.7: Multivariate results: dependent variable: USECAR: Model 5.1.

\begin{tabular}{lcccccc}
\hline Variable & Coefficient & Predicted sign & Value & Standard error & Wald & p-value, 1-t \\
\hline Constant & $\beta_{0}$ & $(?)$ & 0.941 & 1.681 & 0.313 & $0.576^{*}$ \\
LEVEL & $\beta_{1}$ & $(+)$ & 0.264 & 0.621 & 0.181 & 0.671 \\
IMPCI & $\beta_{2}$ & $(+)$ & 0.483 & 0.300 & 2.603 & 0.053 \\
IMPATP & $\beta_{3}$ & $(+)$ & -0.224 & 0.309 & 0.527 & 0.234 \\
TUA & $\beta_{4}$ & $(-)$ & 0.559 & 0.587 & 0.906 & 0.171 \\
TEN & $\beta_{5}$ & $(?)$ & -0.044 & 0.048 & 0.824 & $0.364^{*}$ \\
EDUC & $\beta_{0}$ & $(+)$ & -0.035 & 0.111 & 0.097 & 0.378 \\
\hline
\end{tabular}

$\mathrm{N}=96: \chi^{2}$-test: 5.177 , 6 df, sign.: $0.521 ;$ Pseudo $R^{2}=0.049 ; 81.25 \%$ correctly classified; 1-t: 1-tailed : \# 2-tailed.

\subsubsection{Concluding remarks on research question 1}

Bargaining level has no power in explaining the variation of the use of CARs, neither in the univariate analysis nor in the multivariate analysis. The perceived importance of company specific information is marginally significant, and consequently, the perceived importance of company specific information does appear to play a role in explaining the variation in the use of CARs. The higher the perceived importance of company specific information in general orientation in collective wage bargaining, the more likely CARs are used in collective wage bargaining. This is an important finding 
because it suggests that CARs are a relevant information source to trade union bargainers when they demand company specific information. It indicates that CARs are not without value due to a lack of timeliness or because of the level of aggregation.

The remaining control variables are not significant, suggesting that the variation in the use of CARs in collective wage bargaining can not be explained by (1) the variation in the perceived importance of ability to pay as a justifying argument in making wage claim decisions, by (2) trade union affiliation, by (3) length of tenure as a trade union bargainer or by (4) the level of education of the trade union bargainer. Note that Model 5.1 as a whole is not significant.

\subsection{The perceived importance of CARs: empirical results}

\subsubsection{The dependent variable: IMPCAR}

In this section, the dependent variable is the perceived importance of CARs in collective wage bargaining. Respondents were asked to indicate the importance of CARs in their decision making. The scale ran from 1 (unimportant) to 5 (very important), with an additional possibility to indicate "no opinion/unable to judge". The answers of the 84 respondents that stated they use CARs (see Section 5.6) are presented in Table 5.8 .

Table 5.8: Dependent variable: the perceived importance of CARs to trade union bargainers in collective wage bargaining (IMPCAR): $(\mathrm{N}=84)$.

\begin{tabular}{clrr}
\hline Answer (Likert-scale) & \multicolumn{1}{c}{ IMPCAR } & N & $\%$ \\
\hline 1 & CARs are unimportant in CWB & 1 & 1.2 \\
2 & CARs are slightly important in CWB & 6 & 7.2 \\
3 & CARs are moderate important in CWB & 21 & 25.3 \\
4 & CARs are important in CWB & 41 & 49.4 \\
5 & CARs are very important in CWB & 14 & 16.9 \\
& no opinion/unable to judge & 1 & \\
\hline & total & $\mathbf{8 4}$ & $\mathbf{1 0 0 . 0}$ \\
& mean & 3.73 & \\
& median & 4.00 & \\
\hline
\end{tabular}

CAR: corporate annual report; CWB: collective wage bargaining

The mean score of perceived importance is 3.73 . Of the respondents, $55(66.3 \%)$ consider CARs a (very) important source of information in collective wage bargaining. This is less than reported by Vergoossen $(1994$, p. 72$)$. He found that $90.3 \%$ of the Dutch investment analysts who indicated using CARs consider CARs a (very) important source of information. Dutch loan officers also consider CARs to be more important than do trade union bargainers. Bollen (1996, p.156) reported a 
mean score of importance of 4.73 , which is much higher than the mean score of 3.73 reported in Table 5.8 above. Klaassen and Schreuder (1980) did not include this question in their questionnaire.

\subsubsection{Univariate results}

The dependent variable is ordinal scaled. The independent variables of bargaining level (corporate-level versus industry-level) and trade union affiliation (FNV versus otherwise) are dichotomous. The independent variables of the perceived importance of company specific information, the perceived importance of ability to pay in making wage claims and level of education are ordinal scaled. Length of tenure as a trade union bargainer is interval scaled. We use the Mann-Whitney $\mathrm{U}$ test for $\mathrm{Hl}$ and $\mathrm{H} 4$, and the Spearman rank correlation test to the remaining hypotheses.

Table 5.9 presents the descriptive and univariate results. Note that for $\mathrm{H} 2$ and $\mathrm{H} 3$ the number of observations is less than 83 ( $84-1$, see Table 5.8). This is due to missing observations regarding the independent variable involved.

Table 5.9: The perceived importance of CARs (IMPCARs): descriptive and univariate results.

\begin{tabular}{|c|c|c|c|c|c|c|}
\hline \multirow[t]{2}{*}{ Hypothesis } & \multirow[t]{2}{*}{ Subgroup } & \multirow[t]{2}{*}{$\mathrm{N}$} & \multicolumn{3}{|c|}{$\begin{array}{c}\text { Importance of CARs } \\
\text { (scale 1-5) }\end{array}$} & \multirow[t]{2}{*}{ Univariate results } \\
\hline & & & Mean & Std & Median & \\
\hline \multirow[t]{2}{*}{ H1: LEVEL } & $\mathrm{CL}$ & 57 & 3.895 & 0.748 & 4.000 & \multirow{2}{*}{$\begin{array}{l}\text { MW: }-1.998 ; \\
\text { sign. }(1 \mathrm{t}): 0.023 ; \mathrm{N}=83\end{array}$} \\
\hline & IL & 26 & 3.370 & 1.006 & 4.000 & \\
\hline \multirow[t]{5}{*}{$\mathrm{H} 2: 1 \mathrm{MPCl}$} & 1 (low) & 1 & 1.000 & - & 1.000 & \multirow{5}{*}{$\begin{array}{l}\text { SM: } 0.403 \\
\text { sign. (1t): } 0.000 ; \\
N=82\end{array}$} \\
\hline & 2 & 5 & 3.600 & 0.548 & 4.000 & \\
\hline & 3 & 22 & 3.182 & 0.733 & 3.000 & \\
\hline & 4 & 31 & 3.906 & 0.641 & 4.000 & \\
\hline & 5 (high) & 23 & 4.087 & 0.900 & 4.000 & \\
\hline \multirow[t]{5}{*}{ H3: IMPATP } & 1 (low) & 3 & 4.000 & 1.000 & 4.000 & \multirow{5}{*}{$\begin{array}{l}\text { SM: 0.106; } \\
\text { sign. (1t): } 0.170 ; \\
N=79\end{array}$} \\
\hline & 2 & 5 & 3.200 & 1.095 & 3.000 & \\
\hline & 3 & 11 & 3.500 & 0.522 & 3.000 & \\
\hline & 4 & 33 & 3.818 & 0.950 & 4.000 & \\
\hline & 5 (high) & 27 & 3.741 & 0.859 & 4.000 & \\
\hline \multirow[t]{2}{*}{ H4: TUA } & FNV & 37 & 3.622 & 0.861 & 4.000 & \multirow{2}{*}{$\begin{array}{l}\text { MW: }-1.004 \\
\text { sign. (1t): } 0.158 ; N=83\end{array}$} \\
\hline & Otherwise & 46 & 3.826 & 0.877 & 4.000 & \\
\hline \multirow[t]{3}{*}{ H5: TEN } & Low ( $<4$ years) & 21 & 3.688 & 1.014 & 4.000 & \multirow{3}{*}{$\begin{array}{l}\text { SM: } 0.034 ; \\
\text { sign. }(2 t) ; 0.760 ; \\
N=83\end{array}$} \\
\hline & Medium ( $4-8$ years) & 35 & 3.659 & 0.855 & 4.000 & \\
\hline & High (>8 years) & 27 & 3.852 & 0.818 & 4.000 & \\
\hline \multirow[t]{2}{*}{ H6: EDUC } & Low (level 1-8) & 22 & 3.636 & 0.658 & 4.000 & \multirow{2}{*}{$\begin{array}{l}\text { SM: } 0.118 ; \\
\text { sign. (1t): } 0.143 ; N=83\end{array}$} \\
\hline & High (level 9-12) & 61 & 3.758 & 0.935 & 4.000 & \\
\hline
\end{tabular}

MW: Mann-Whitney z-score; SM: Spearman rank correlation coefficient; 1t: 1-tailed; 2t: 2-tailed; sign; significance level.

$\mathrm{H} 1$ investigates the relation between perceived importance of CARs and bargaining 
level. CL-bargainers consider CARs to be more important than do IL-bargainers (mean: 3.895 versus 3.370 ). The difference is significant. $\mathrm{Hl}$ is supported.

$\mathrm{H} 2$ tests whether trade union bargainers who believe company specific information plays an important role in the stage of general orientation in collective wage bargaining consider CARs to be more important than do other bargainers. The perceived importance of company specific information was measured on a five-point scale with an additional possibility to indicate "no opinion/unable to judge" (see Appendix 5A at the end of the chapter for details). There is a significant, positive relation between the perceived importance of company specific information in general orientation in collective wage bargaining, and the perceived importance of CARs. H2 is supported.

$\mathrm{H} 3$ tests whether trade union bargainers who perceive ability to pay to be a more important justifying argument in making wage claims perceive CARs as more important. The perceived importance of ability to pay was measured on a five-point scale with an additional possibility to indicate "no opinion/unable to judge" (see Appendix $5 \mathrm{~A}$ at the end of the chapter for details). Though the magnitude of the relation is as expected, the relation is not significant. H3 is not supported.

$\mathrm{H} 4$ focuses on the relation between the perceived importance of CARs and trade union affiliation. To measure the independent variable, respondents were asked to indicate the trade union federation affiliation. To decrease the number of categories and to increase the number of observations in the categories, trade union affiliation is treated as a dummy variable, taking the value 1 in the case of a FNV-bargainer and the value 0 otherwise. FNV-bargainers consider CARs as less important than do other trade union bargainers (mean: 3.622 versus 3.826); however, the difference is not significant. $\mathrm{H} 4$ is not supported.

$\mathrm{H} 5$ tests whether a significant relation exists between length of tenure as a trade union bargainer and the perceived importance of CARs. To measure the independent variable, respondents were asked to indicate how many years they have been working as a trade union bargainer. The relation is not significant. H5 is not supported.

$\mathrm{H} 6$ investigates the relation between the perceived importance of CARs and the level of education of the trade union bargainer. To measure the independent variable, respondents were asked to indicate their level of education on a 12-point scale (see Appendix 5A at the end of the chapter for details). The relation is not significant. H6 is not supported.

Overall, the data provide support for $\mathrm{H} 1$ and $\mathrm{H} 2$, suggesting that trade union 
bargainers who are involved in CL-bargaining and bargainers who perceive the role of company specific information in general orientation in collective wage bargaining to be more important, tend to consider CARs in collective wage bargaining more important than do other bargainers. Of some interest is the finding that the importance of CARs is determined by the perceived importance of company specific information in general orientation in collective wage bargaining and not by the perceived importance of ability to pay as a justifying argument in making wage claim decisions.

\subsubsection{Multivariate results}

This section investigates whether the combination of independent variables can explain the variation in the importance of CARs. We use linear regression to investigate the determinants of the ordinal scaled dependent variable IMPCAR (cf. Schroeder et al. [1986], Pedhazur and Pedhazur [1991], Carcello et al. [1992], Dassen [1995], Hartmann [1997]).

The following model was estimated:

IMPCAR $=\beta_{0}+\beta_{1} L E V E L+\beta_{2} I M P C I+\beta_{3} I M P A T P+\beta_{4} T U A+\beta_{5} T E N+\beta_{6} E D U C+\epsilon$

These variables are defined as follows:

IMPCAR: Perceived importance of CARs in collective wage bargaining (scale 1 to $5: 1=$ low; $5=$ high). LEVEL: $\quad$ Dummy variable indicating bargaining level ( $1=\mathrm{CL}$-bargaining, 0 =lL-bargaining).

IMPCl: $\quad$ Perceived importance of company specific information in the stage of general orientation in collective wage bargaining (scale 1 to 5 : $1=$ low; $5=$ high).

IMPATP: Perceived importance of ability to pay as an argument in making wage claim decisions (scale 1 to $5: 1=$ low; 5 =high).

TUA: $\quad$ Dummy variable indicating trade union affiliation ( $1=F N V, 0=0$ therwise).

TEN: $\quad$ Length of tenure as a trade union bargainer (in years).

EDUC: Level of education of the trade union bargainer (scale 1 to $12: 1=$ low; 12=high).

The correlations between the independent variables were presented in Table 5.6. There it was concluded that multicollinearity does not pose a problem.

Table 5.10 shows that the parameter of bargaining level is marginally significantly different from zero, and in the expected direction. Of the control variables the perceived importance of company specific information and trade union affiliation are significant and in the expected direction. Model 5.2 as a whole is significant $(\mathrm{F}=3.980$, 6df, sign.: 0.002). The model explains $18.8 \%$ of the variation of the perceived importance of CARs, suggesting that almost one-fifth of the variation in the perceived importance of CARs is explained by the variables studied here. 
Table 5.10: Multivariate results: dependent variable IMPCAR: Model 5.2.

\begin{tabular}{lcccccc}
\hline Variable & Coefficient & Predicted sign & Value & Standard error & t-value & p-value, 1-tailed \\
\hline Constant & $\beta_{6}$ & $(?)$ & 1.813 & 0.581 & 3.119 & $0.003^{*}$ \\
LEVEL & $\beta_{1}$ & $(+)$ & 0.396 & 0.212 & 1.871 & 0.033 \\
IMPCI & $\beta_{2}$ & $(+)$ & 0.358 & 0.103 & 3.485 & 0.001 \\
IMPATP & $\beta_{3}$ & $(+)$ & 0.057 & 0.094 & 0.606 & 0.274 \\
TUA & $\beta_{4}$ & $(-)$ & -0.270 & 0.185 & -1.485 & 0.075 \\
TEN & $\beta_{5}$ & $(?)$ & -0.288 & 0.015 & -0.189 & $0.851^{*}$ \\
EDUC & $\beta_{6}$ & $(+)$ & 0.020 & 0.040 & 0.496 & 0.311 \\
\hline
\end{tabular}

N=78: $\$$ 2-tailed, 6 di, $F=3.980$, sign. 0.002; Adj. $R^{2}=0.188$.

\subsubsection{Concluding remarks on research question 2}

The univariate and multivariate analysis find that bargaining level is a significant explanatory variable. CL-bargainers consider CARs to be more important than do ILbargainers. Of the control variables, the perceived importance of company specific information in general orientation in collective wage bargaining is significant in the univariate and multivariate analysis. Trade union affiliation is marginally significant in the multivariate analysis, but not in the univariate analysis.

The multivariate results may be interpreted as follows. Bargainers who perceive CARs to be more important in collective wage bargaining bargain more often at corporatelevel, consider company specific information more important in general orientation in collective wage bargaining, and they tend to be less often affiliated with the FNV.

5.8 The perceived importance of the consolidated income statement: empirical results

\subsubsection{The dependent variable: IMPCIS}

The respondents were asked on a five-point Likert-scale to indicate the importance of the consolidated income statement in collective wage bargaining. The scale ran from 1 (unimportant) to 5 (very important), with an additional possibility to indicate "no opinion/unable to judge". The answers of the 84 respondents who indicated the use of CARs are summarised in Table 5.11. 
Table 5.11: Dependent variable: the perceived importance of the consolidated income statement in collective wage bargaining (IMPCIS) $(\mathrm{N}=84)$.

\begin{tabular}{clcr}
\hline Answer (Likert-scale) & \multicolumn{1}{c}{ IMPCIS } & N & $\%$ \\
\hline 1 & CISs are unimportant in CWB & 4 & 4.9 \\
2 & CISs are slightly important in CWB & 11 & 13.4 \\
3 & CISs are moderate important in CWB & 18 & 22.0 \\
4 & CISs are important in CWB & 33 & 40.2 \\
5 & CISs are very important in CWB & 16 & 19.5 \\
& no opinion/unable to judge & 2 & \\
\hline & total & $\mathbf{8 4}$ & 100.0 \\
& mean & 3.56 & \\
& median & $\mathbf{4 . 0 0}$ & \\
\hline
\end{tabular}

CIS: consolidated income statement; CWB: collective wage bargaining.

Overall, the importance is ranked as 3.56 on the 1 to 5 scale. Of the respondents, 49 $(59.8 \%)$ consider the consolidated income statement important, while 15 respondents (18.3\%) consider it slightly important or unimportant. Note that the perceived importance of CARs is 3.73 , while that of the consolidated income statement is 3.56 . One possible explanation for this is that the combination of different parts makes the $\mathrm{CAR}$ as a whole more important than the single consolidated income statement.

The perceived importance of the consolidated income statement as found in this chapter is much lower than reported by Klaassen and Schreuder (1980). In that study (p.49), $88.9 \%$ of the respondents considered the consolidated income statement (very) important. They also found that $89.5 \%$ of respondents who were members of works councils considered the consolidated income statement (very) important. Vergoossen (1994, p. 77 ) found that $94.2 \%$ of the Dutch investment analysts consider the consolidated income statement a (very) important segment of CARs. Dutch loan officers also consider the consolidated income statement to be more important than do trade union bargainers. Bollen (1996, p.156) reported a mean score of importance of 4.88 , whereas we found a mean score of 3.56 in the case of trade union bargainers. Note that this comparison is partly hampered because Bollen studied the perceived importance of the income statement, while we investigate the perceived importance of the consolidated income statement.

\subsubsection{Univariate results}

Since the importance of the consolidated income statement is measured on a five-point scale like the importance of the CAR, we apply the same tests in the univariate analysis here as we did in Section 5.7.

Table 5.12 presents the descriptive and univariate results. Note that for $\mathrm{H} 2$ and $\mathrm{H} 3$ the number of observations is less than $82(84-2$, see Table 5.11$)$. This is due to missing 
data regarding the independent variable involved.

Table 5.12: The perceived importance of the consolidated income statement (IMPCIS): descriptive and univariate results.

\begin{tabular}{|c|c|c|c|c|c|c|}
\hline \multirow[t]{2}{*}{ Hypothesis } & \multirow[t]{2}{*}{ Subgroup } & \multirow[t]{2}{*}{$\mathrm{N}$} & \multicolumn{3}{|c|}{ Importance of CIS (scale 1.5) } & \multirow[t]{2}{*}{ Univariate results } \\
\hline & & & Mean & Std & Median & \\
\hline \multirow[t]{2}{*}{ HI:LEVEL } & $\mathrm{CL}$ & 56 & 3.589 & 1.023 & 4.000 & \multirow{2}{*}{$\begin{array}{l}\text { MW: }-0.036 ; \text { sign. (11): } \\
0.486 ; N=82\end{array}$} \\
\hline & IL & 26 & 3.500 & 1.273 & 4.000 & \\
\hline \multirow[t]{5}{*}{ H2: $1 \mathrm{MPCl}$} & 1 (low) & 1 & 2.000 & - & 2.000 & \multirow{5}{*}{$\begin{array}{l}\text { SM: } 0.168 ; \\
\text { sign. (1t); } 0.067 \\
N=81\end{array}$} \\
\hline & 2 & 5 & 3.000 & 1.414 & 4.000 & \\
\hline & 3 & 21 & 3.333 & 1.111 & 4.000 & \\
\hline & 4 & 31 & 3.742 & 1.094 & 4.000 & \\
\hline & 5 (high) & 23 & 3.696 & 1.020 & 4.000 & \\
\hline \multirow[t]{5}{*}{ H3: IMPATP } & 1 (low) & 3 & 3.000 & 1.732 & 2.000 & \multirow{5}{*}{$\begin{array}{l}\text { SM: 0.128; } \\
\text { sign. (1t): } 0.131 ; \\
N=78\end{array}$} \\
\hline & 2 & 4 & 3.500 & 1.291 & 3.500 & \\
\hline & 3 & 11 & 3.545 & 1.214 & 4.000 & \\
\hline & 4 & 33 & 3.485 & 1.121 & 4.000 & \\
\hline & 5 (high) & 27 & 3.815 & 1.001 & 4.000 & \\
\hline \multirow[t]{2}{*}{ H4: TUA } & FNV & 37 & 3.541 & 0.931 & 4.000 & \multirow{2}{*}{$\begin{array}{l}\text { MW: }-0.565 ; \\
\text { sign. (1t): } 0.286 ; N=82\end{array}$} \\
\hline & Otherwise & 45 & 3.578 & 1.233 & 4.000 & \\
\hline \multirow[t]{3}{*}{ H5: TEN } & Low ( $<4$ years) & 20 & 3.350 & 1.268 & 4.000 & \multirow{3}{*}{$\begin{array}{l}\text { SM: } 0.040 \\
\text { sign. (2t): } 0.720 \\
N=82\end{array}$} \\
\hline & Medium (4-8) & 35 & 3.800 & 0.933 & 4.000 & \\
\hline & High ( $>8$ years) & 27 & 3.407 & 1.152 & 4.000 & \\
\hline \multirow[t]{2}{*}{ H6: EDUC } & Low (level 1-8) & 21 & 3.524 & 1.030 & 4.000 & \multirow{2}{*}{$\begin{array}{l}\text { SM: } 0.085 ; \text { sign. (1t) } \\
0.224 ; N=82\end{array}$} \\
\hline & High (level 9-12) & 61 & 3.574 & 1.132 & 4.000 & \\
\hline
\end{tabular}

MW: Mann-Whitney z-score; SM: Spearman rank correlation coefficient; 1t: 1-tailed; 2t: 2-tailed; sign: significance level.

$\mathrm{H} 1$ focuses on the impact of bargaining level on the perceived importance of the consolidated income statement. CL-bargainers consider the consolidated income statement slightly more important than do IL-bargainers (mean: 3.589 versus 3.500 ). Although the difference is in the expected direction, it is not significant for conventional levels of significance. $\mathrm{H} 1$ is not supported.

$\mathrm{H} 2$ expects a significant and positive relation between the perceived importance of the consolidated income statement and the perceived importance of company specific information in the stage of general orientation in collective wage bargaining. The perceived importance of company specific information was measured on a five-point scale with an additional possibility to indicate "no opinion/unable to judge" (see Appendix 5A at the end of the chapter for details). The relation is in the expected direction. There is marginally support for $\mathrm{H} 2$.

$\mathrm{H} 3$ expects a positive relation between the perceived importance of the consolidated income statement and the perceived importance of ability to pay as a justifying argument in making wage claim decisions. The perceived importance of ability to pay was measured on a five-point scale with an additional possibility to indicate "no 
opinion/unable to judge" (see Appendix 5A at the end of the chapter for details). There is no support for $\mathrm{H} 3$.

H4 focuses on the extent to which the perceived importance of the consolidated income statement can be explained by the variable trade union affiliation. To measure the independent variable, respondents were asked to indicate their current trade union federation affiliation. To decrease the number of categories and to increase the number of observations in the categories, trade union affiliation is treated as a dummy variable, taking the value 1 in the case of a FNV-bargainer and the value 0 otherwise. FNV-bargainers consider the consolidated income statement as less important than do other trade union bargainers (mean: 3.541 versus 3.578 ); however, the difference is not significant. $\mathrm{H} 4$ is not supported.

In H5 the focus is on length of tenure as a trade union bargainer. To measure the independent variable, respondents were asked to indicate how many years they have been working as a trade union bargainer. The relation between the perceived importance of the consolidated income statement and length of tenure as a trade union bargainer is far from significant. H5 is not supported.

H6 investigates the relation between the perceived importance of the consolidated income statement and the level of education. A positive relation is expected. To measure the independent variable, respondents were asked to indicate their level of education on a 12-point scale (see Appendix 5A at the end of the chapter for details). The relation is not significant. There is no supported for H6.

\subsubsection{Multivariate results}

As in Section 5.7.3, we use linear regression to investigate the determinants of the perceived importance of the consolidated income statement. The following model was estimated:

IMPCIS $=\beta_{0}+\beta_{1} L E V E L+\beta_{2} I M P C I+\beta_{3} I M P A T P+\beta_{4} T U A+\beta_{5} T E N+\beta_{0} E D U C+\epsilon$

These variables are defined as follows:

IMPCIS: Perceived importance of the consolidated income statement (scale 1 to $5: 1=10 w ; 5=h i g h$ ). LEVEL: $\quad$ Dummy variable indicating bargaining level ( $1=\mathrm{CL}$-bargaining, $0=\mathrm{IL}$-bargaining).

IMPCl: Perceived importance of company specific information in the stage of general orientation in collective wage bargaining (scale 1 to $5: 1=$ low; $5=$ high).

IMPATP: $\quad$ Perceived importance of ability to pay as an argument in making wage claim decisions (scale 1 to 5 : 1 =low; 5 =high).

TUA: $\quad$ Dummy variable indicating trade union affiliation ( $1=\mathrm{FNV}, 0=$ otherwise).

TEN: $\quad$ Length of tenure as a trade union bargainer (in years). 
The correlations between the independent variables were presented in Table 5.6. There it was concluded that multicollinearity does not pose a problem.

Table 5.13 summarises the results of the multivariate test. It shows that bargaining level is not significant. The only control variable that is significantly different from zero, and in the expected direction is the perceived importance of company specific information. Model 5.3 as a whole is not significant ( $\mathrm{F}=1.461,6 \mathrm{df}$, sign.: 0.204).

Table 5.13: Multivariate results: dependent variable: IMPCIS: Model 5.3.

\begin{tabular}{lcccccc}
\hline Variable & Coefficient & Predicted sign & Value & Standard error & t-value & p-value, 1-t. \\
\hline Constant & $\beta_{0}$ & $(?)$ & 2.064 & 0.808 & 2.554 & $0.013^{*}$ \\
LEVEL & $\beta_{1}$ & $(+)$ & -0.016 & 0.297 & -0.039 & 0.485 \\
IMPCI & $\beta_{2}$ & $(+)$ & 0.320 & 0.144 & 2.224 & 0.015 \\
IMPATP & $\beta_{3}$ & $(+)$ & 0.066 & 0.135 & 0.487 & 0.314 \\
TUA & $\beta_{6}$ & $(-)$ & 0.006 & 0.260 & -0.024 & 0.491 \\
TEN & $\beta_{3}$ & $(?)$ & -0.029 & 0.022 & -1.304 & $0.197^{*}$ \\
EDUC & $\beta_{6}$ & $(+)$ & 0.032 & 0.054 & 0.583 & 0.281 \\
\hline
\end{tabular}

$\mathrm{N}=77 ;$ \# 2-tailed; 6df, $\mathrm{F}=1.461$, sign. 0.204; Adj. $\mathrm{R}^{2}=0.035$.

\subsubsection{Concluding remarks on research question 3}

The results with regard to the analysis of the determinants of the perceived importance of the consolidated income statement are limited. The variable bargaining level is of foremost interest to us. This variable is not significant. With regard to the control variables, the univariate and multivariate analysis reveal a (marginally) significant positive relationship between the perceived importance of the consolidated income statement and the perceived importance of company specific information in general orientation in collective wage bargaining. The perceived importance of ability to pay as a justifying argument in making wage claim decisions is not significant. This suggests that the variation in the perceived importance of the consolidated income statement is related to the perceived importance of company specific information for general orientation in collective wage bargaining, but not for specific decision making such as determining the ability to pay wages. The remaining variables are not significant.

\subsection{Summary and overall conclusions}

This chapter addresses the question: Do trade union bargainers use corporate annual reports and do they perceive corporate annual reports as important, and if so, what explains the variation in usage and perceived importance? The approach was 
threefold. The main research question is split into three more detailed research questions: (1) What is the use of corporate annual reports by trade union bargainers, and what explains the variation in usage? (Section 5.6); (2) What is the importance of corporate annual reports as perceived by trade union bargainers who use CARs, and what explains the variation in perceived importance? (Section 5.7); (3) What is the importance of the consolidated income statement as perceived by trade union bargainers who use corporate annual reports and what explains the variation in perceived importance (Section 5.8)?

The independent variable of main interest throughout this chapter is bargaining level. Subsequently, the impact of five control variables is studied: (1) the importance of specific information in the stage of general orientation in collective wage bargaining, (2) the perceived importance of ability to pay as a justifying argument in making wage claim decisions, (3) trade union affiliation, (4) the level of education of the trade union bargainer, and (5) the length of tenure as a trade union bargainer.

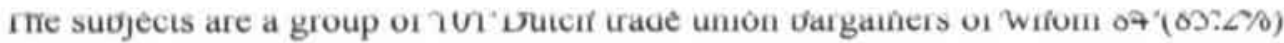
indicate the use of CARs in collective wage bargaining. Of the users of CARs, $66.3 \%$ consider CARs a (very) important source of information in collective wage bargaining while $59.8 \%$ of the users of CARs perceive the consolidated income statement as (very) important. Table 5.14 below is a copy of Table 5.2, with the inclusion of the results of this chapter.

Table: 5.14: The findings of previous studies and the results of this chapter.

\begin{tabular}{|c|c|c|c|c|c|c|}
\hline Study & Subjects & $\mathrm{N}$ & $\begin{array}{l}\text { Response } \\
\text { rate } \\
\text { in } \%\end{array}$ & $\begin{array}{l}\text { Use of } \\
\text { CARs } \\
\text { in } \%\end{array}$ & $\begin{array}{l}\text { Imp. of CARs } \\
\text { [\%(very) imp] } \\
\text { \{mean\} }\end{array}$ & $\begin{array}{l}\text { Imp. of CIS } \\
\text { [\%(very) imp] } \\
\text { \{mean\} }\end{array}$ \\
\hline \multirow{6}{*}{$\begin{array}{l}\text { Klaassen } \\
\text { and } \\
\text { Schreuder } \\
(1980)\end{array}$} & Shareholders & 175 & n.r. & n.r. & n.r. & [94.3] \\
\hline & Directors & 80 & n.r. & n.r. & n.r. & [78.3] \\
\hline & Staff employees & 66 & n.r. & n.r. & n.r. & [81.8] \\
\hline & Investment advisors & 40 & n.r. & n.r. & n.r. & {$[94.4]$} \\
\hline & Members works council & 27 & n.r. & n.r. & n.r. & [89.5] \\
\hline & Total & $640^{\circ}$ & 16.8 & n.r. & n.r. & $\begin{array}{l}{[88.9]} \\
\{4.39\}\end{array}$ \\
\hline $\begin{array}{l}\text { Vergoossen } \\
\text { (1993) }\end{array}$ & Investment analysts & 205 & 51.8 & 85.4 & $\begin{array}{l}{[90.3]} \\
\{4.59\}\end{array}$ & $\begin{array}{l}{[94.2]} \\
\{4.67\rangle\end{array}$ \\
\hline $\begin{array}{l}\text { Bollen } \\
\text { (1996) }\end{array}$ & Loan officers & 80 & 42.6 & 97.5 & $\begin{array}{l}{[80.0]} \\
\{4.73\}\end{array}$ & $\{4.88\}^{\circ}$ \\
\hline This chapter & Trade union bargainers & 101 & 60.1 & 83.2 & $\begin{array}{l}{[66.3]} \\
\{3.73\}\end{array}$ & $\begin{array}{l}{[59.8]} \\
\{3.56\}\end{array}$ \\
\hline
\end{tabular}

a: 252 respondents had either another relation to the company whose CAR was used, or they did not answer this question; b: Bollen only investigated the importance of the income statement and not of the consolidated income statement: Imp: importance; scale 1-5: 1=unimportant: 5=very important: CIS: consolidated income statement, imp: important; n.r.: not reported. 
We were most successful in answering research question 2: explaining the variation of the perceived importance of CARs. Table 5.15 summarises the results. Overall, the explanatory power of the variables considered here is limited.

Table 5.15: Summary of the significance of the independent variables: univariate and multivariate results $(\mathrm{N}=101)$.

\begin{tabular}{|c|c|c|c|c|c|c|c|}
\hline \multirow[b]{2}{*}{$\begin{array}{l}\text { Independent } \\
\text { Variable }\end{array}$} & & \multicolumn{2}{|c|}{$\begin{array}{l}\text { Research question 1: } \\
\text { USECAR ( } \mathrm{N}=101)\end{array}$} & \multicolumn{2}{|c|}{$\begin{array}{l}\text { Research question 2: } \\
\text { IMPCAR }(\mathrm{N}=84)\end{array}$} & \multicolumn{2}{|c|}{$\begin{array}{l}\text { Research question 3: } \\
\text { IMPCIS }(\mathrm{N}=84)\end{array}$} \\
\hline & & $\begin{array}{l}\text { Univariate } \\
\text { analysis }\end{array}$ & $\begin{array}{l}\text { Multivariate } \\
\text { analysis }\end{array}$ & $\begin{array}{l}\text { Univariate } \\
\text { analysis }\end{array}$ & $\begin{array}{l}\text { Multivariate } \\
\text { analysis }\end{array}$ & $\begin{array}{l}\text { Univariate } \\
\text { analysis }\end{array}$ & $\begin{array}{l}\text { Multivariate } \\
\text { analysis }\end{array}$ \\
\hline LEVEL & $1-t$ & & & $*$ & $*$ & & \\
\hline $1 \mathrm{MPCl}$ & $1-t$ & - & - & $\cdots$ & $\cdots$ & - & ** \\
\hline IMPATP & $1-1$ & & & & & & \\
\hline TUA & $1-t$ & & & & • & & \\
\hline TEN & $2-t$ & & & & & & \\
\hline EDUC & $1-t$ & $*$ & & & & & \\
\hline
\end{tabular}

$1-t=1$-taled: $2-t=2$-talled; ${ }^{c *}$ significant at the $1 \%$-level; ${ }^{* *}$ significant at the $5 \%$-level; " significant at the $10 \%$-level.

The explanatory power of bargaining level (LEVEL) is somewhat disappointing. It is only significant in explaining the perceived importance of CARs. CL-bargainers consider CARs to be significantly more important than do IL-bargainers. The only control variable that is robust in all analyses is the perceived importance of company specific information in general orientation in collective wage bargaining (IMPCI). Bargainers who rank the perceived importance of company specific information in general orientation in collective wage bargaining higher, more often use CARs and rank the perceived importance of CARs and of consolidated income statements higher as well. Trade union affiliation (TUA) and level of education of the trade union bargainer (EDUC) are only significant in a partial analysis. The perceived importance of ability to pay as a justifying argument in making wage claim decisions (IMPATP) and length of tenure as a trade union bargainer (TEN) are not of influence in explaining the variation of the dependent variables.

The perceived importance of company specific information in general orientation in collective wage bargaining is a significant variable throughout the analyses, as opposed to the perceived importance of ability to pay as a justifying argument in making wage claim decisions. The data do support the hypothesis that trade union bargainers use CARs and the consolidated income statement for general orientation in collective wage bargaining. Yet, no evidence was found that this information is used for the purpose of specific decision making, like for making wage claim decisions. This is in line with the results reported by Klaassen and Schreuder (1980, p.29). They found that over $85 \%$ of the respondents, including members of works councils, use CARs for the purpose of general orientation. At the same time, our findings contradict the results reported by Vergoossen (1994, p.67) and Bollen (1996, 
p.160). Vergoossen found that only $38.9 \%$ of the investment analysts in his study use CARs for general orientation. Bollen also found that loan officers use sections of CARs less often for the purpose of general orientation than for specific decision making.

Research opportunities and policy implications following from this chapter will be discussed in Chapter 8. 


\section{Appendix 5A: Relevant part of the questionnaire}

Table 5.16 summarises the relevant questions of the questionnaire. The CL-version of the questionnaire is presented below, and the IL-version is similar. The introduction to the questionnaire explained that the focus was on collective wage bargaining. The questions are presented in the same order as in the chapter. Please note that this is not the original order as presented to the trade union bargainers.

Table 5.16: Relevant part of the questionnaire: version CL-bargaining.

\begin{tabular}{|c|c|c|}
\hline Variable & Original question (in Dutch) & Translation of the question \\
\hline & $\begin{array}{l}\text { Beantwoord de onderstaande vragen } \\
\text { vanuit uw ervaring als onderhandelaar } \\
\text { over ondernemings-CAO's. }\end{array}$ & $\begin{array}{l}\text { Please answer the questions below based on your } \\
\text { experience as a corporate-level bargainer. }\end{array}$ \\
\hline USECAR & $\begin{array}{l}\text { Maakt } u \text { in het kader van } \\
\text { onderhandelingen over een } \\
\text { ondememings-CAO gebruik van } \\
\text { financielle jaarverslagen? }\end{array}$ & $\begin{array}{l}\text { Do you use corporate annual reports in the context of } \\
\text { corporate-level collective wage bargaining? } \\
\text { (yes/nol }\end{array}$ \\
\hline IMPCAR & $\begin{array}{l}\text { Geef aan hoe belangrijk voor u het } \\
\text { meest recente financieel jaarverslag is } \\
\text { in het kader van onderhandelingen } \\
\text { over een ondernemings-CAO. }\end{array}$ & $\begin{array}{l}\text { How important is the most recent corporate annual } \\
\text { report to you in the context of corporate-level collective } \\
\text { wage bargaining? } \\
\text { [5-point scale: } 1 \text { : unimportant - 5: very important or "no } \\
\text { opinion/unable to judge"] }\end{array}$ \\
\hline IMPCIS & $\begin{array}{l}\text { Hoe belangrijk is voor } u \text { de } \\
\text { geconsolideerde winst-en } \\
\text { verliesrekening in het kader van } \\
\text { onderhandelingen over een } \\
\text { ondernemings-CAO? }\end{array}$ & $\begin{array}{l}\text { How important is the consolidated income statement to } \\
\text { you in the context of corporate-level collective wage } \\
\text { bargaining? } \\
\text { [5-point scale: } 1 \text { : unimportant - } 5 \text { : very important or "no } \\
\text { opinion/unable to judge"] }\end{array}$ \\
\hline LEVEL & $\begin{array}{l}\text { U bent voornamelijk betrokken bij het } \\
\text { afsluiten van (juiste antwoord } \\
\text { aankruisen s.v.p.) } \\
\text {-ondememings-CAO's of } \\
\text {-bedrijfstak-CAO's }\end{array}$ & $\begin{array}{l}\text { You are mainly involved with (tick the right answer } \\
\text { please) } \\
\text {-corporate-level collective wage bargaining or } \\
\text {-industry-level collective wage bargaining }\end{array}$ \\
\hline $\mathrm{IMPCl}$ & $\begin{array}{l}\text { Hoe belangrijk is voor } u \text { in } \\
\text { onderhandelingen over een } \\
\text { ondememings-CAO, de informatie } \\
\text { over de ondememing waarover } u \\
\text { onderhandelt? }\end{array}$ & $\begin{array}{l}\text { Given the context of corporate-level collective wage } \\
\text { bargaining, how important is information concerning the } \\
\text { company involved to you? } \\
\text { [5-point scale: } 1 \text { : unimportant - } 5 \text { : very important or "no } \\
\text { opinion/unable to judge"] }\end{array}$ \\
\hline IMPATP & $\begin{array}{l}\text { Stel } u \text { onderhandelt bij ondememing } x \\
\text { over een ondememings-CAO. Hoe } \\
\text { belangnijk is voor } u \text { de loonnuimte van } \\
\text { ondermeming } x \text { bij het formuleren van } \\
\text { uw eisen tijdens deze CAO. } \\
\text { onderhandelingen? }\end{array}$ & $\begin{array}{l}\text { Suppose you are negotiating the collective wage } \\
\text { bargaining contract of company } x \text {. How important is the } \\
\text { company's ability to pay to you when determining your } \\
\text { demands? } \\
\text { [5-point scale: } 1 \text { : unimportant - } 5 \text { : very important or "no } \\
\text { opinion/unable to judge"] }\end{array}$ \\
\hline TUA & Bij welke vakbondfederatie werkt u? & $\begin{array}{l}\text { With which trade union federation are you affiliated? } \\
\text { [open ended] }\end{array}$ \\
\hline$\overline{\text { TEN }}$ & $\begin{array}{l}\text { Hoeveel jaar ervaring heeft } u \text { als } \\
\text { vakbondsonderhandelaar inzake } \\
\text { onderhandelingen over } \\
\text { ondermemings-CAO's? }\end{array}$ & $\begin{array}{l}\text { How many years of experience do you have as a trade } \\
\text { union bargainer with regard to corporate-level collective } \\
\text { wage bargaining? } \\
\text { [open ended] }\end{array}$ \\
\hline EDUC & $\begin{array}{l}\text { Wat is uw vooropleiding? (uw hoogst } \\
\text { behaalde examen). }\end{array}$ & $\begin{array}{l}\text { What is your level of education? (your highest degree) } \\
\text { [closed question: } 12 \text { answering categories, 1: primary } \\
\text { school - 12: university degreed/ business } \\
\text { administration] }\end{array}$ \\
\hline
\end{tabular}




\section{Appendix 5B: Test for non-response bias}

The test for non-response bias was performed by comparing the answers of the first 25 respondents (median number of days needed to return the questionnaire: 5) with the last 25 respondents (median number of days needed to return the questionnaire: 32). Table 5.17 below depicts the results.

Table 5.17: Mann-Whitney U-test for non-response bias (all results 2-tailed).

\begin{tabular}{|c|c|c|c|c|c|c|c|c|}
\hline \multirow[t]{2}{*}{ Variable } & \multicolumn{3}{|c|}{ Early respondents $(\mathrm{N}=25)$} & \multicolumn{3}{|c|}{ Late respondents $(\mathrm{N}=25)$} & \multirow[t]{2}{*}{ z-score } & \multirow[t]{2}{*}{ p-value } \\
\hline & Mean & Std & Median & Mean & Std & Median & & \\
\hline Days & 5.040 & 1.241 & 5.000 & 40.600 & 18.129 & 32.000 & -6.115 & 0.000 \\
\hline USECAR & 0.960 & 0.200 & 1.000 & 0.840 & 0.374 & 1.000 & -1.400 & 0.162 \\
\hline IMPCAR & 3.458 & 0.884 & 4.000 & 3.160 & 1.313 & 3.000 & -0.758 & 0.449 \\
\hline IMPCIS & 3.571 & 0.811 & 4.000 & 3.737 & 1.046 & 4.000 & -0.105 & 0.916 \\
\hline $\mid \mathrm{MPCl}$ & 3.640 & 0.860 & 4.000 & 3.760 & 0.879 & 4.000 & -0.536 & 0.592 \\
\hline IMPATP & 3.957 & 1.022 & 4.000 & 3.833 & 1.167 & 4.000 & -0.212 & 0.832 \\
\hline TEN & 9.560 & 6.640 & 7.000 & 10.200 & 7.071 & 8.000 & -0.058 & 0.953 \\
\hline EDUC & 7.640 & 2.752 & 9.000 & 8.120 & 2.713 & 9.000 & -0.953 & 0.340 \\
\hline
\end{tabular}

For questions and response scales see Appendix 5A, Table 5.16. 


\section{Notes}

1. The author wishes to thank Laury Bollen and Gerard Mertens for helpful comments on an earlier version of this chapter. An earlier version of this chapter was presented at the 21 st Annual Congress of the European Accounting Association in Antwerp in 1998, and at a research fonum organised by the Limperg Institute in Amsterdam in 1998.

2. For more on the Dutch system of collective wage bargaining and on the dual bargaining structure see Appendix B at the end of this dissertation. For examples of the contents of Duteh collective wage contracts see Appendix $\mathrm{C}$ at the end of this dissertation.

3. See e.g. Klaassen and Schreuder (1980, pp.29-30), Vergoossen (1993, p.67) and Bollen (1996, p.156).

4. Possible relevant information includes information on employees (number of employees, part-time/full-time, sex, geographic location), employee costs (wages and additional costs), health and safety issues (accidents, labour conditions), new investments affecting the number of jobs of the quality of it, R\&D and training expenses etc.

5. Previous research that deals with the usefulness of accounting information to trade unions includes Cooper and Essex (1977), Palmer (1977), Foley and Maunders (1979), Ward (1987), Mautz (1990), Clarke and Craig (1992) and McBarnet et al. (1993). This literature is reviewed in Section 3.2.2 of this dissertation.

6. Studies on the impact of accounting information on the process and outcome of collective bargaining include Amernic (1985), Amernic and Aranya (1990), Bougen et al. (1990), Elias (1990), Chalos et al. (1991), Morishima (1991), and Amernic and Craig (1992). This literature is discussed in Section 3.2 .3 of this dissertation.

7. See for example Baker and Haslem (1973), Epstein (1975), Lee and Tweedie (1975a, 1975b, 1976), Chang and Most (1977 and 1985), Anderson (1981), Arnold and Moizer (1984), Arnold et al. (1984), Day (1986) and Epstein and Pava (1993).

8. The remaining $2.8 \%$ of the respondents did not answer the question.

9. The main point is that in some companies trade unions bargain directly with executive management (corporate-level bargaining or CL-bargaining) and in other companies trade unions bargain with representatives of companies within the industry (industry-level bargaining or IL-bargaining).

10. See Section 4.4 of this dissertation.

11. See also Cooper and Essex (1977).

12. In 1999 the three largest Dutch trade union federations are: $F N V(1,225,800$ members $)$, CNV (361,000 members) and MHP (218,600 members) (source: CBS, 2000). 
13. White-collar workers generally see themselves as belonging more with management than with manual workers (Salamon, 1998, pp.153-154).

14. The FNV is historically most close to the Social Democratic Party and the CNV to the Christian Democratic Party. The MHP has no historical link to a specific political party.

15. See Windmuller et al. (1990, p.269).

16. Another reason to focus on the impact of the level of education is to see whether training trade union bargainers on accounting affairs is a potentially fruitful way to increase the use and perceived importance of (segments of) CARs.

17. The questionnaire is available from the author on request.

18. Questionnaires were mailed between December 1994 and May 1995. After about three weeks the bargainers received a reminder.

19. These newspapers are Het Financieele Dagblad, NRC Handelsblad, de Volkskrant, and De Telegraaf. They were screened from August 1st, 1992 until March 31, 1995.

20. This approach was adopted for several reasons. First, we were not aware of any central and publicly available registration of the names of trade union bargainers. Second, we wanted only respondents who were experienced in collective wage bargaining in the profit sector. Third, to allow cross-sectional analysis and given the small population of Dutch bargainers, we had to adopt an approach leading to a high response rate.

21. Our response rate is above that of comparable studies such as Lee and Tweedie (1975a), Chang and Most (1977), Klaassen and Schreuder (1980), Vergoossen (1993) and Bollen (1996). These had response rates of $23.5 \%, 21.5 \%, 16.8 \%, 43.0 \%, 42.6 \%$, respectively.

22. See Appendix B for an introduction to the main Dutch trade union federations.

23. See Siegel and Castellan (1988, p.49).

24. Further analysis reveals that users have slightly less working experience on average compared with non-users (mean: 7.9 years versus 8.5 years). The median scores reveal a large difference (median: 5.5 years versus 8.0 years).

25. The main advantage of multivariate regression over univariate analysis is that the contribution of each independent variable to the variation of the dependent variable can be measured, while all other independent variables are controlled for.

26. Technically, in the context of logistic regression, USECAR must of course be read as the natural $\log$ of the odds of a respondent saying he/she indeed uses CARs (see e.g. Hutcheson and Sofroniou, 1999, Chapter 4). 


\section{Chapter 6 \\ The Audit Expectations Gap: \\ A study among trade union bargainers}

\subsection{Introduction}

The audit expectations gap (AEG) can be defined as the gap between the public's expectations of independent auditors (further referred to as auditors) and the public's perceptions of auditors. AEGs are a problem for the auditing profession. In 1986, the chairman of the Public Oversight Board (AICPA, 1986) characterised the expectation problem as follows:'

"investors and depositors are losing faith in the ability of the accounting profession to perform the job which has historically been its unique function in our society - assuring the integrity of the financial information upon which our capitalistic society necessarily depends."

The AEG has received much attention both in the academic literature and in the financial press. Daily newspapers in the Netherlands have also called the work of auditors into question. ${ }^{2}$

Although previous research has investigated the AEG from a variety of perspectives, none took the trade union perspective. This is intriguing because trade unions are important players in business. Furthermore, we found in Chapter 5 that the trade unions use audited corporate annual reports (CARs) and we know that trade unions have pointed at the existence of an AEG before. For instance, CNV chairman Westerlaken implicitly indicated the existence of a gap when he discussed the financial difficulties of the Dutch truck producing company DAF: ${ }^{3}$

"(...) would it not have been better if the auditors of DAF had warned others besides management of the bad (financial) position of DAF Finance with large risks for other healthy parts of the organisation? The question is, if the auditors had warned the public of those developments, whether more jobs could have been saved. Put differently, if the auditors had defined their duty more broadly, would not that have caused fewer social losses than is the case right now?"

The intention of this dissertation is to contribute to the AEG literature by focusing on 
trade union bargainers. The central research question of this chapter is:

Do trade union bargainers have an audit expectations gap, and if so, what explains the variation in the gap?

Again, the setting is the Netherlands. From a theoretical perspective, the AEG may be broken down into three components: the performance gap, the standards gap and the reasonableness gap. ${ }^{4}$ Below we will discuss these gaps in detail. The approach of the empirical part of this chapter is threefold. Each of the three empirical parts will address one detailed research question which in turn is split into a number of hypotheses. The focus is on the following research questions.

1. Is there a performance gap (defined as the discrepancy between trade union bargainers' expectations of the performance of existing auditor duties and the perceived performance of these duties), and if so, what variables explain the variation of the performance gap? (Section 6.6).

2. Is there a standards gap (defined as the gap between what trade union bargainers can reasonably expect of auditors, and the actual existing duties of auditors, which have been established by legislation, Code of Conduct, professional standards and other requirements), and if so, what variables explain the variation in the standards gap? (Section 6.7).

3. Is there a reasonableness gap (defined as the extent to which trade union bargainers expect auditors to conduct duties that cannot reasonably be expected of auditors), and if so, what variables explain the variation in the reasonableness gap? (Section 6.8).

This chapter is organised as follows. Section 6.2 presents the theoretical framework. Section 6.3 provides a brief overview of previous research on the AEG. Section 6.4 develops the hypotheses of this chapter. Section 6.5 presents the research design and discusses the characteristics of the respondents. Section 6.6 to 6.8 present the empirical results. Finally, Section 6.9 provides a summary and overall conclusions.

Table 6.1 summarises how the empirical part of this chapter is composed.

Table 6.1: The composition of the empirical part of this chapter.

\begin{tabular}{llc}
\hline Dependent variable & Analysis & Section \\
\hline The performance gap & univariate & 6.6 .2 \\
& multivariate & 6.6 .3 \\
\hline The standards gap & univariate & 6.7 .2 \\
& multivariate & 6.7 .3 \\
\hline The reasonableness gap & univariate & 6.8 .2 \\
& multivariate & 6.8 .3 \\
\hline
\end{tabular}


Note that internal auditors, by nature of their relationship with the company, are not independent from executive management. Therefore this chapter focuses only on public registered (external) auditors ("openbare registeraccountants").

\subsection{Theoretical framework}

As was explained in detail in Chapter 2, corporate annual reports (CARs) are potentially useful to trade union bargainers in collective wage bargaining, for general orientation and for specific decision making, like determining the company's ability to pay. Chapter 5 found that the variation in usage and perceived importance of CARs is especially related to the perceived importance of company-specific information in general orientation in collective wage bargaining.

The auditors' service to society is to provide credibility and assurance regarding the information presented by the company. As with all services, there may be a gap between the service expected and the service provided.

As indicated, the existence of an AEG is a problem for the auditing profession. Investigating the existence, nature and variation of the AEG is a first step towards narrowing it.

\section{3}

Relations to previous empirical research

The literature on the AEG comes from two sources: from national auditors organisations (e.g. AICPA [1978 and 1986], CICA [1988], ICAI [1992], ACCA [1992], ICAEW [1992], NIVRA [1992]) and from audit researchers. Reviews of the reports of national auditor's organisations and further references can be found in Humphrey (1991), Humphrey et al. (1993) and Gloeck and de Jager (1993). Audit researchers have mainly investigated the AEG in the Anglo-Saxon world. For extensive overviews of research on the AEG, both empirical and non-empirical, see Gwilliam (1987), Humphrey (1991), Humprey et al. (1993), Porter (1993), and Deegan and Rankin (1999).

Previous research found AEGs with regard to the auditors' responsibility in detecting fraud and informing third parties about it, the nature of balance sheet valuations, and the auditors' ability to cope with risk and uncertainty (Humprey et al., 1993). Others found AEGs with regard to the auditors' role in reporting going concern problems and their role in reporting serious matters to regulators if management fails to do so (Gloeck and De Jaeger, 1993). The wording of auditor's reports appears to create an 
AEG as well (Monroe and Woodcliff, 1994), and it was also found that different subgroups have different AEGs (Porter, 1993; Monroe and Woodcliff, 1994).

In the Netherlands, two studies dealt with the AEG: one conducted by the Limperg Institute (1987) and one by Dassen (1995).

The Limperg Institute (1987) studied the views of various interest groups on auditors. The interest groups were members of supervisory boards, managing directors of small, medium-sized and large companies, directors of not-for-profit organisations, bankers, members of works councils and shareholders. A gap was found between the expected performance of auditors and the perceived performance. Furthermore, auditors were believed to serve the interest of the company instead of that of the society. Members of works councils showed the largest gap between the expectations and actual perceptions of the impact of statutory audits on the quality of the information in CARs. A gap was also found with regard to the role of the auditor in fraud detection and regarding the reporting of going concern problems to outsiders. The interpretation of the wording of unqualified and qualified audit opinions also caused problems. Finally, members of works councils expected auditors to report the evasion of taxation and social securities to a regulatory authority.

Dassen (1995) studied the AEG of clients and bankers in the Netherlands. He found several gaps between expected and perceived auditor performance levels, even though the overall quality level was quite high. Bankers had higher expectations regarding technical and service quality attributes than did clients. No differences were found as to the size of the AEGs with regard to non-traditional auditor's duties (e.g. detecting and reporting of fraud or illegal acts) versus traditional duties (detecting and reporting of errors or smoothing in the annual accounts).

From the last two studies it can be concluded that several interest groups in the Netherlands have an AEG. Note that employee representatives (members of works councils) also had an AEG (Limperg Institute, 1987) and in some respects the AEG of members of works councils was larger than that of other users of auditor's reports.

\section{4}

Development of the hypotheses

There are three reasons for a possible gap between trade union bargainers' expectations of auditors and their perceptions of auditors. First, previous studies showed that a diverse set of professional users have an AEG.' Since trade unions are professional users of CARs too, it is possible that they also have an AEG. Second, previous research in the Netherlands among employee representatives revealed the 
existence of an AEG (Limperg Institute, 1987). Since trade unions are employee representatives too, they may also have an AEG. Third, quotes like the one presented in Section 6.1 seem to indicate that trade unions have an AEG.

\subsubsection{The dependent variables}

To investigate the AEG of trade union bargainers we will adopt the approach used by Porter (1993). ${ }^{6}$ In this approach, the AEG is split into three components. This approach provides a more sophisticated view of the AEG. The focus is on:

1. The performance gap: defined as the discrepancy between trade union bargainers' expectations of the performance of existing auditor duties and the perceived performance of these duties.

2. The standards gap: defined as the discrepancy between what trade union bargainers can reasonably expect of auditors, and the actual existing duties of auditors, which have been established by legislation, Code of Conduct, professional standards and other requirements. These duties fall within the economic and professional sphere.

3. The reasonableness gap: defined as the extent to which trade union bargainers expect auditors to conduct duties that cannot reasonably be expected of auditors. Auditors cannot typically conduct these duties from an economic and professional point of view.

We will not measure the size of the AEG as a whole. This requires that single duties be weighted. Our aim is more modest. We limit our analysis to investigating the existence of the AEG. The idea is that the AEG exists as soon as evidence indicates the existence of one or more of the components of the AEG. And a component of the AEG exists as soon as evidence indicates the existence of one or more duties of the component.

Given this approach, in the analyses below the focus is on the following three dependent variables: the performance gap, the standards gap and the reasonableness gap.

\subsubsection{The independent variables}

We will test the explanatory power of four variables. As in Chapters 4,5 and 7 , the focus is on bargaining level as the main explanatory variable. The variation of the AEG may also be determined by other variables. The impact of three control variables on the AEG will be studied as well: (1) trade union affiliation, (2) level of education 
of the trade union bargainer, and (3) length of tenure as a trade union bargainer. In Section 5.4 of this dissertation, the four variables were introduced in detail.

This chapter is exploratory in that we have no a priori expectations about the impact of the independent variables on the dependent variables. This is because no previous work has focused on the interaction under study. Therefore, the hypotheses below are all stated in the alternative form. Since the direction of the impact of the independent variables on the dependent variable is the subject of investigation, the hypotheses will be tested two-sided.

\subsubsection{Hypothesis 1: the impact of bargaining level}

The dual collective wage bargaining system of the Netherlands is introduced in Chapter 1, summarised in Chapter 4 and more broadly clarified in Appendix B at the end of this dissertation.' We believe the role of CARs potentially differs in CLbargaining and IL-bargaining. Company-specific information is potentially more important in CL-bargaining than in IL-bargaining. As a result, CL-bargainers probably use audited information and meet auditors more often than do IL-bargainers. This is confirmed in Chapter 5. There it was found that CL-bargainers consider corporate annual reports significantly more important than IL-bargainers. If CLbargainers have positive experiences with auditors and audits, CL-bargainers probably have a lower AEG on average. Experiences might also be negative, causing a reverse effect. Since little is known about the actual experiences, we hypothesise that:

H1 The performance gap, the standards gap and the reasonableness gap are related to bargaining level (LEVEL).

\subsubsection{Hypothesis 2: trade union affiliation}

Section 5.4 positioned the FNV on the left side of the trade union spectrum, the MHP on the right and the $\mathrm{CNV}$ in between. We have no a priori expectations of the impact of the relation between trade union affiliation and the components of the AEG; therefore, we hypothesise that:

H2 The performance gap, the standards gap and the reasonableness gap are related to trade union affiliation (TUA).

\subsubsection{Hypothesis 3: length of tenure as a trade union bargainer}

Narrowing the AEG is especially important for the auditing profession if there is a 
positive relation between the magnitude of the AEG and length of tenure as a trade union bargainer. Senior bargainers typically shape trade union policy, and therefore their perceptions potentially have a stronger impact on trade union responses to the AEG. Since we have no expectations as to the direction of the relation between the components of the AEG and length of tenure as a trade union bargainer, we hypothesise that:

H3 The performance gap, the standards gap and the reasonableness gap are related to length of tenure as a trade union bargainer (TEN).

\subsubsection{Hypothesis 4: the level of education of the trade union bargainer}

Bollen (1996, p.166) found a significant relation between the level of education and the perceived quality of auditor's reports. Loan officers more highly trained in business administration perceived the quality of auditor's reports to be lower, compared to other loan officers. We will also focus on the level of education of the trade union bargainer to see whether it can explain the components of the AEG. Since we expect little variation in trade union bargainers' training in business administration, we will focus on the interaction between the level of general education and the components of the AEG. Since we have no a priori expectations of the direction of the interaction, we hypothesise that:

H4 The performance gap, the standards gap and the reasonableness gap are related to the level of education of trade union bargainers (EDUC).

\subsection{Research method and respondents' characteristics}

\subsubsection{Research method: questionnaire and sample}

This chapter is questionnaire-based." The data for Chapter 6 and 7 were collected simultaneously. The questionnaire had three segments. The first segment collected data on the AEG (for Chapter 6), the second segment on auditor independence (for Chapter 7) and the third segment on personal characteristics, to obtain a profile of the respondents (for Chapters 6 and 7). Subjects received a cover letter, a questionnaire and a prepaid return envelope.' The entire questionnaire consisted of 30 questions, some of which were further divided.

For the purpose of this chapter, we distinguished ten auditor duties, all of them potentially relevant to trade union bargainers. The selection was based on a review of existing and possible audit duties, legal requirements, professional guidelines and 
previous literature. Before the final selection was made, the possible duties were discussed with an experienced trade union bargainer. The ten duties included (1) existing duties (to investigate the performance gap), (2) duties not presently existing but that can reasonably be expected of auditors (to investigate the standards gap) and (3) duties that cannot reasonably be expected of auditors (to investigate the reasonableness gap). With regard to the closed questions, trade union bargainers were instructed to express their opinions on a five-point Likert-scale, arranged as follows: 1) strongly disagree, 2) disagree, 3) neutral, 4) agree, 5) strongly agree. There was an additional possibility to indicate "no opinion/unable to judge". Table 6.2 provides an overview of the ten duties studied.

Table 6.2: Duties proposed to the respondents.

\begin{tabular}{lll}
\hline Gap & & \multicolumn{1}{c}{ Duty } \\
\hline PERFGAP & a & To conduct statutory audits. \\
& b & To inform management / board of supervisors on IO deficiencies. \\
& c & To report going concern problems to outsiders. \\
\cline { 2 - 4 } & d & To audit the company's interim accounts. \\
& STANDGAP & To discuss the company's financial position with the works council. \\
& f & To review the outcome of the employee profit sharing plan. \\
& h & To inform works councils on IO deficiencies. \\
\hline REASONGAP & i & To audit and report the efficiency and effectiveness of management. \\
& To audit the compliance with the Law on Labour Conditions. & To audit the impact on the local community and environment. \\
\hline
\end{tabular}

AEG: audit expectations gap; PERFGAP: performance gap; STANDGAP: standards gap: REASONGAP: reasonableness gap; 10: internal organisation.

To increase the validity of the research instrument, the questionnaire was based on questionnaires used in previous studies. The first segment of the questionnaire was based on those used by the Limperg Instituut (1987) and by Porter (1993), while the third segment of the questionnaire was based on those used by Klaassen and Schreuder (1980), Vergoossen (1993) and Bollen (1996)..$^{10}$

The questionnaire was discussed in detail with three accounting researchers who had conducted comparable studies among other users of CARs. To make sure that the questions were easy to understand feedback from colleagues was also solicited. After modifications, the questionnaire was discussed with an experienced trade union bargainer who has been involved in collective wage bargaining for over 20 years. The relevant parts of the questionnaire are attached to this chapter as Appendix $6 \mathrm{~A}$.

To construct a sample of trade union bargainers, an existing file was used which contained the names of bargainers involved in collective wage bargaining. The file was prepared for the purpose of Chapter 5 of this dissertation. Section 5,5.1 describes the procedures followed to compose the sample. 
As summarised in Table 6.3, 168 questionnaires were sent and 105 questionnaires were returned, of which 104 were usable. The response rate is $61.9 \%$. This is satisfactory in comparison with other studies."

Table 6.3: Response rate.

\begin{tabular}{lc}
\hline & Response rate \\
\hline Questionnaires mailed & 168 \\
Returned and completed & 105 \\
Usable & 104 \\
Response rate & $104 / 168=0.619$ \\
\hline
\end{tabular}

Before the data can be used, some considerations of possible non-response bias are needed. The non-response bias is tested by comparing the answers of early respondents with those of late respondents (Moser and Kalton, 1986; Oppenheim. 1992, Hartmann, 1997). The test results can be found in Appendix 6B at the end of this chapter. No significant differences were found between the early and late respondents, suggesting that the views of respondents are not expected to differ significantly from those from non-respondents. Given this, we expect little problem in generalising the results.

\subsubsection{Respondents' characteristics}

Table 6.4 shows that of the 104 respondents, $67(64.4 \%)$ are CL-bargainers, 32 $(30.8 \%)$ are IL-bargainers and $5(4.8 \%)$ respondents indicated bargaining at both levels to the same extent. Furthermore, $45(43.3 \%)$ of the respondents are affiliated with the FNV, $31(29.8 \%)$ with the CNV, $24(23.1 \%)$ with the MHP, while the remaining $4(3.8 \%)$ are affiliated with some smaller trade unions. On average they have 9.5 years bargaining experience and the majority is highly educated. On average, the respondents conclude 5.6 collective bargaining contracts yearly; the average bargaining span of CL-bargainers is 9,400 employees, and that of the IL-bargainers over 118,000 employees.

In Table 6.4, the two variables related to bargaining span (number of contracts and number of employees) will not be used in the analysis below, because these variables will strongly correlate with the independent variable of main interest: bargaining level (CL-bargainers versus IL-bargainers). 
Table 6.4: Respondents' characteristics.

\begin{tabular}{|c|c|c|c|c|}
\hline & & & & $\begin{array}{l}\text { level } \\
\text { ) }\end{array}$ \\
\hline & & ALL & $\mathrm{CL}$ & IL \\
\hline $\bar{N}$ & $\mathrm{~N}$ & 104 & 67 & 32 \\
\hline & $\%$ & 100.0 & 66.4 & 30.8 \\
\hline Trade union affiliation & FNV & 45 & 34 & 11 \\
\hline (TUA) & CNV & 31 & 20 & 11 \\
\hline & MHP & 24 & 17 & 7 \\
\hline & Other & 4 & 1 & 3 \\
\hline Length of tenure as a & Mean & 9.5 & 9.6 & 9.5 \\
\hline trade union bargainer" & Std & 6.8 & 6.8 & 7.0 \\
\hline (TEN) & Min & 0.3 & 0.3 & 1 \\
\hline & Max & 28 & 28 & 28 \\
\hline Education $^{6}$ & Low & 11 & 6 & 5 \\
\hline (EDUC) & Medium & 20 & 16 & 4 \\
\hline & High & 73 & 45 & 23 \\
\hline Bargaining span: number & Mean & 5.6 & 5.0 & 6.8 \\
\hline of collective bargaining & Std & 5.6 & 2.4 & 9.1 \\
\hline contracts $^{e}$ & Min & 1 & 1 & 1 \\
\hline & $\operatorname{Max}$ & 50 & 12 & 50 \\
\hline Baroainiog soan: & Mean & 45.4 & 9.4 & 118 \\
\hline number of employees ${ }^{d}$ & Std & 93.5 & 15.9 & 135.1 \\
\hline & Min & 0.2 & 0.2 & 0.4 \\
\hline & $\operatorname{Max}$ & 600 & 100 & 600 \\
\hline
\end{tabular}

$\mathrm{a}=$ length of tenure as a trade union bargainer in years; $\mathrm{b}=$ education: scale 1 to $12: 1-3=$ low; $4-8=$ medium; 9 $12=h i g h$; $c=$ in contracts per year; $d=i n$ 1,000 employees per year; $C L$ : corporate-level bargainers; IL: industry-level bargainers; FNV: Federatie Nedertandse Vakbeweging, CNV: Christelijk Nationaal Vakverbond; MHP: Vakcentrale for Middelbaar en Hoger Personeel.

\subsection{The performance gap: empirical results}

\subsubsection{The dependent variable: PERFGAP}

The performance gap of bargainer $i$ with regard to Duty $x$ (PERFGAP P $_{i, 2}$ can be defined as the discrepancy between his expectations of the performance of auditors with regard to Duty $\mathrm{x}$ and his perceptions of the actual performance of auditors with regard to Duty $\mathrm{x}$. So:

PERFGAP $_{G x}=$ Expected Performance $_{i x}$ - Perceived Performance $\left.\right|_{i, x}$

The expected performance is regarded as the individual standard of performance at which the perceived performance will be benchmarked. Therefore, the performance gap can be regarded as an indication of the level of disappointment. So, the performance gap of bargainer i with regard to Duty $\mathrm{x}$ can take three forms: 
1. PERFGAP $u<0$ : perceived performance of Duty $x$ is above the standard of bargainer $i$

2. PERFGAP $=0$ : perceived performance of Duty $x$ is at standard of bargainer $i$

3. PERFGAP $\mathrm{G}>0$ : perceived performance of Duty $x$ is below the standard of bargainer $i$

The performance gap can be presented as follows.

Figure 6.1: The performance gap of bargainer $i$ with regard to auditor Duty $x$.

\begin{tabular}{|c|c|c|}
\hline $\begin{array}{l}\text { PERFGAP }<<0 \\
\text { (performance > } \\
\text { expectations) }\end{array}$ & $\begin{array}{l}\text { PERFGAP }_{\mathrm{G}}=0 \\
\text { (performance = } \\
\text { expectations) }\end{array}$ & $\begin{array}{l}\text { PERFGAP, }>0 \\
\text { (performance < } \\
\text { expectations) }\end{array}$ \\
\hline $\begin{array}{l}\text { Perceived performance } \\
\text { is above standard }\end{array}$ & $\begin{array}{l}\text { Perceived performance } \\
\text { is at standard }\end{array}$ & $\begin{array}{l}\text { Perceived performance } \\
\text { is below standard }\end{array}$ \\
\hline
\end{tabular}

To measure the performance gap, the respondents were asked to indicate the extent to which they support each of the following three propositions:

Duty a: Auditors are sufficiently successful in conducting statutory audits.

Duty b: Auditors are sufficiently successful in informing the directors and board of supervisors on internal organisation deficiencies.

Duty c: $\quad$ Auditors are sufficiently successful in reporting going concern problems to outsiders.

Duty $\mathrm{a}$ is the traditional role of the auditor and is rooted in the financial accounting legislation (Cf. Book 2, Civil Code, Title 9, Article 393, Section 1). Duty b is also legally determined. Based on the same legislation (Cf. Book 2, Civil Code, Title 9 , Article 393, Section 3) auditors are obliged to inform management and the board of supervisors on the audit findings. Finally, based on the NIVRA Code of Professional Conduct (NIVRA [1995],Gedrags-en Beroepsregels, 1994, Article 17.2), and on audit standards (NIVRA [2000], Richtlijnen voor de Accountantscontrole, 2000, Subject Matter Number 700, Paragraph 31) auditors are obliged to add a note to the auditor's report in case of going concern problems ("ernstige onzekerheid omtrent de continuïteit").

The respondents were requested to answer on a five-point scale, coded as -2 if respondents strongly agree with the proposition, coded as -1 if they agree with it, coded as 0 if they are neutral, coded as +1 if they disagree with it, and coded as +2 if they strongly disagree with it. There was an additional opportunity to tick "no opinion/unable to judge". In the proposition the word "sufficiently" means that the respondent is asked to benchmark perceived performance to expected performance, thereby indicating the size of the gap. Therefore, given Figure 6.1 above, the performance gap can be presented as follows. 
Figure 6.2: The performance gap of bargainer $i$ with regard to Duty $x$.

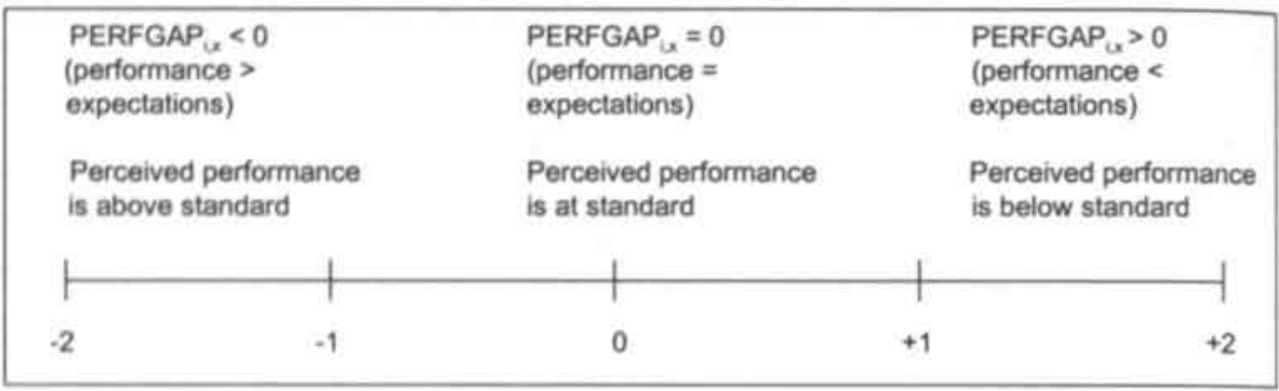

Respondents who provided answer -2 have the largest positive gap between perceived performance and expected performance with regard to Duty $\mathrm{x}$, while respondents who provided answer +2 have the largest negative gap. Table 6.5 summarises the results.

Table 6.5: The performance gap: theoretical range, mean, median, standard deviation, $\%<0, \%>0, z$ score and number of observations.

\begin{tabular}{lcccccccc}
\hline Duty & $\begin{array}{c}\text { Theoretical } \\
\text { range }\end{array}$ & Mean & Median & $\begin{array}{c}\text { Standard } \\
\text { deviation }\end{array}$ & $\%<0$ & $\%>0$ & $\begin{array}{c}\mathbf{z} \text {-score } \\
\text { median } \neq 0\end{array}$ & $\mathrm{~N}$ \\
\hline $\mathrm{a}$ & -2 to +2 & -0.40 & 0.00 & 1.03 & 48.0 & 19.6 & $-3.552^{\circ}$ & 102 \\
$\mathrm{~b}$ & -2 to +2 & 0.64 & 1.00 & 1.17 & 15.7 & 59.6 & $-5.756^{\circ}$ & 89 \\
c & -2 to +2 & 0.77 & 1.00 & 1.17 & 14.6 & 65.6 & $-4.834^{\circ}$ & 96 \\
\hline
\end{tabular}

Duty a: auditors are sufficiently successful in conducting statutory audits; Duty b: auditors are sufficiently successful in informing the management and board of supervisors on internal organisation deficiencies; Duty c: auditors are sufficiently successful in reporting going concern problems to outsiders; one-sample Wilcoxon signed ranks zscores; $\varphi$ significant at the 1 per cent level (2-tailed).

In this chapter we use three decision rules to conclude whether the performance of an existing duty is perceived as substandard: (1) whether the mean score is positive, (2) whether the median score is positive (one-sample Wilcoxon signed ranks test, see Hollander and Wolfe, 1999, p.79), and (3) whether $33.3 \%$ or more of the respondents consider the performance of the duty as substandard. If $33.3 \%$ or more of the respondents consider the performance as substandard, the duty is considered substandard sufficiently widespread to contribute to the performance gap. Note that the last two decision rules are also used by Porter (1993), though she was a little less conservative by adopting a $20 \%$-boundary with regard to the third decision rule.

Table 6.5 shows that the mean score of Duty a is negative $(-0.40)$ and median score is negative ${ }^{12}$ and significantly different from zero (one-sample Wilcoxon signed ranks test z-score: -3.552 , sign. [2-tailed]: 0.000$)^{13}$. Furthermore, slightly less than $20 \%$ of the respondents consider this duty substandard. Based on these decision rules we conclude that this Duty a does not contribute to the performance gap. The mean and median scores of Duty b (0.64 and 1.00$)$ and Duty c $(0.77$ and 1.00$)$ are positive and 
significantly different from zero (one-sample Wilcoxon signed ranks test z-score; Duty b: -5.756 , sign. [2-tailed]: 0.000 ; Duty c: -4.834 , sign. [2-tailed]: 0.000 ). Of the respondents, $59.6 \%$ (Duty b) and $65.6 \%$ (Duty c) are not satisfied with how the duty is performed. This suggests that based on all decision rules the performance of these two duties is below expectation, and consequently they contribute to the performance gap. Note that for all three duties, the number of observations is less than 104. This is due to missing observations of the dependent variables.

\subsubsection{Univariate results}

The dependent variable is ordinal scaled. The independent variables bargaining level (corporate-level versus industry-level) and trade union affiliation (FNV versus otherwise) are dichotomous. Level of education is ordinal scaled and length of tenure as a trade union bargainer is interval scaled. We use the Mann-Whitney U test for $\mathrm{HI}$ and $\mathrm{H} 2$, and the Spearman rank correlation test for $\mathrm{H} 3$ and $\mathrm{H} 4$. Table 6.6 presents the univariate results.

Table 6.6: The performance gap: univariate results: Mann-Whitney z-scores (LEVEL, TUA) and Spearman correlation coefficients (TEN, EDUC).

\begin{tabular}{lrrrr}
\hline & H1: LEVEL & H2: TUA & H3: TEN & \multicolumn{1}{c}{ H4: EDUC } \\
\hline Duty a & $-0.045[p=0.964]$ & $-0.955[p=0.340]$ & $-0.132[p=0.188]$ & $0.131[p=0.190]$ \\
Duty b & $-0.856[p=0.392]$ & $-1.114[p=0.265]$ & $0.002[p=0.989]$ & $0.198[p=0.065]$ \\
Duty c & $-0.482[p=0.630]$ & $-0.826[p=0.409]$ & $0.092[p=0.301]$ & $-0.166[p=0.107]$ \\
\hline
\end{tabular}

LEVEL: $1=\mathrm{CL}, 0=\mathrm{IL}$; TUA: $1=\mathrm{FNV}, 0=0$ therwise; all test results are 2-tailed.

One relation is marginally significant. More highly educated trade union bargainers tend to be less satisfied with the way auditors inform the management and board of supervisors on internal organisation deficiencies than are less educated bargainers. Therefore, there is some support for $\mathrm{H} 4$, though only in a partial analysis.

\subsubsection{Multivariate results}

This section investigates whether the combination of independent variables can explain the variation in the performance gap. The main advantage of multivariate analysis over univariate analysis is that the contribution of each independent variable to the variation of the dependent variable can be measured, while all other independent variables are controlled.

We use linear regression to investigate the determinants of the Likert scale-based estimation of the performance gap (cf. Schroeder et al. [1986], Pedhazur and Pedhazur [1991], Carcello et al. [1992], Dassen [1995], Hartmann [1997]). 
The following models will be tested:

$\begin{array}{ll}\text { Duty } a= & \beta_{0}+\beta_{1} \text { LEVEL }+\beta_{2} \text { TUA }+\beta_{3} \text { TEN }+\beta_{4} E D U C+\epsilon \\ \text { Duty } b= & \beta_{0}+\beta_{1} \text { LEVEL }+\beta_{2} \text { TUA }+\beta_{3} \text { TEN }+\beta_{4} E D U C+\epsilon \\ \text { Duty } c= & \beta_{0}+\beta_{1} \text { LEVEL }+\beta_{2} \text { TUA }+\beta_{3} \text { TEN }+\beta_{6} E D U C+\epsilon\end{array}$

These variables are defined as follows:

Duty a: Auditors are sufficiently successful in conducting statutory audits (scale -2 to 2 : $-2=$ strongly agree; 2 =strongly disagree).

Duty b: Auditors are sufficiently successful in informing the management and board of supervisors on internal organisation deficiencies (scale -2 to 2 : $-2=$ strongly agree; $2=$ strongly disagree).

Duty c: Auditors are sufficiently successful in reporting going concern problems to outsiders (scale -2 to $2:-2=$ strongly agree; $2=$ strongly disagree).

LEVEL: Dummy variable indicating level of collective wage bargaining ( $1=\mathrm{CL}$-bargaining, $0=\mathrm{IL}$ bargaining).

TUA: Dummy variable indicating trade union affiliation ( $1=F N V, 0=0$ therwise).

TEN: Length of tenure as a trade union bargainer (in years).

EDUC: Level of education of the trade union bargainer (scale 1 to 12: 1=low; 12=high).

Multivariate analysis may be hampered by the presence of multicollinearity. Multicollinearity can be traced by observing the associations between the independent variables. Table 6.7 is a matrix of the correlation of the independent variables. If one or both measures are dichotomous, the Cramér coefficient is the most appropriate measure of association (Siegel and Castellan, 1988, p.225). The Cramér coefficient has a maximum value of 1 , and $C$ equals 0 when the variables are independent. To analyse the relations between bargaining level and trade union affiliation, and between bargaining level and length of tenure as a trade union bargainer, the Cramér coefficient is presented. To test for the association between length of tenure as a trade union bargainer and level of education of the trade union bargainer, the Spearmanrank correlation test is used. All correlations are low to modest. Therefore, multicollinearity does not seem to pose a problem here.

Table 6.7: Correlation matrix.

\begin{tabular}{lccc}
\hline & LEVEL & TUA & TEN \\
\hline TUA & $0.147[p=0.145]$ & & \\
TEN & $0.487[p=0.774]$ & $0.583[p=0.205]$ & \\
EDUC & $0.290[p=0.509]$ & $0.333[p=0.249]$ & $-0.191[p=0.054]$ \\
\hline
\end{tabular}

LEVEL: $1=\mathrm{CL}, 0=\mathrm{IL}$; TUA: $1=\mathrm{FNV}, 0=0$ therwise.

Table 6.8 summarises the results from Model 6.1 to 6.3. In Model 6.1 length of tenure as a trade union bargainer is marginally significant and negative, suggesting that more experienced trade union bargainers tend to consider auditors more successful in conducting statutory audits than less experienced trade union bargainers. The overall explanatory power (adjusted $\mathrm{R}^{2}$ ) of all three models is poor, suggesting that the 
influence of the multitude of variables included in the models is small. None of the models is significant.

Table 6.8: Multivariate results: Model 6.1 to 6.3.

\begin{tabular}{|c|c|c|c|c|c|c|}
\hline Variable & Coefficient & Predicted sign & Value & Standard error & t-value & $p$-value $(2-t)$ \\
\hline \multicolumn{7}{|c|}{ Model 6.1: Duty a: Conducting statutory audits. } \\
\hline Constant & $\beta_{0}$ & (?) & -0.546 & 0.394 & -1.387 & 0.169 \\
\hline LEVEL & $B_{1}$ & (?) & -0.191 & 0.218 & -0.877 & 0.383 \\
\hline TUA & $\beta_{2}$ & (?) & 0.233 & 0.215 & 1.084 & 0.281 \\
\hline TEN & $\beta_{3}$ & (?) & -0.026 & 0.015 & -1.722 & 0.088 \\
\hline EDUC & $\beta_{4}$ & (?) & 0.054 & 0.037 & 1.452 & 0.150 \\
\hline
\end{tabular}

F-value=1.619; sign. 0.176; adj. R2:0.026; $N=95$.

Model 6.2: Duty b: Informing the management and board of supervisors on 10 deficiencies.

\begin{tabular}{lllrrrr}
\hline Constant & $\beta_{6}$ & $(?)$ & -0.047 & 0.498 & -0.095 & 0.925 \\
LEVEL & $\beta_{1}$ & $(?)$ & 0.073 & 0.274 & 0.265 & 0.792 \\
TUA & $\beta_{2}$ & $(?)$ & 0.395 & 0.275 & 1.434 & 0.156 \\
TEN & $\beta_{3}$ & $(?)$ & -0.010 & 0.019 & -0.529 & 0.598 \\
EDUC & $\beta_{4}$ & $(?)$ & 0.070 & 0.049 & 1.444 & 0.153
\end{tabular}

F-value=1.074; sign. $0.375 ;$ adj. $R 2: 0.004 ; \mathrm{N}=82$.

Model 6.3: Duty c: Reporting going concern problems to outsiders.

\begin{tabular}{|c|c|c|c|c|c|c|}
\hline Constant & $\beta_{0}$ & (?) & 0.920 & 0.488 & 1.887 & 0.063 \\
\hline LEVEL & $\beta_{1}$ & (?) & 0.036 & 0.272 & 0.132 & 0.896 \\
\hline TUA & $\mathrm{B}_{2}$ & (?) & 0.218 & 0.269 & 0.808 & 0.422 \\
\hline TEN & $\beta_{3}$ & (?) & 0.009 & 0.019 & 0.461 & 0.646 \\
\hline EDUC & $\beta_{4}$ & (?) & -0.041 & 0.046 & -0.893 & 0.375 \\
\hline
\end{tabular}

F-value $=0.546$; sign. $0.702 ;$ adj. $R 2 ;-0.021 ; N=89$.

LEVEL: $1=\mathrm{CL}, 0=\mathrm{IL}$; TUA: $1=\mathrm{FNV}, 0=0$ therwise; 10 : internal organisation; 2-t: 2-tailed.

\subsubsection{Concluding remarks on research question 1}

Trade unions perceive the performance of auditors with regard to conducting statutory audits satisfactory, and with regard to informing the management and board of supervisors on internal organisation deficiencies and reporting going concern problems to outsiders to be below standard. Consequently, there is a performance gap consisting of the last two duties. The independent variables under study have almost no explanatory power. In the univariate analysis, the level of education of the trade union bargainer is marginally significant in explaining Duty b. In the multivariate analyses, length of tenure as a trade union bargainer is marginally significant in explaining Duty a. Overall, there is some limited support for $\mathrm{H} 3$ and $\mathrm{H} 4$, though only in partial analyses. 


\subsection{The standards gap: empirical results}

\subsubsection{The dependent variable: STANDGAP}

The standards gap of bargainer $i$ can be defined as the extent to which bargainer $i$ expects auditors to conduct duties that are presently not being performed but that can reasonably be expected of auditors. The standards gap of bargainer $i$ with regard to Duty y can take three forms:

1. STANDGAP $\mathrm{iy}<0$ : bargainer $\mathrm{i}$ does not expect auditors to conduct Duty y

2. STANDGAP $=0$ : bargainer $i$ is neutral about whether auditors should conduct Duty y

3. STANDGAP $i,>0$ : bargainer i does expect auditors to conduct Duty y

To measure the standards gap, the respondents were asked to indicate the extent to which they agree with each of the following four propositions.

Duty d: I expect auditors to audit interim accounts.

Duty e: lexpect auditors to discuss the company's financial position with the works council.

Duty f: I expect auditors to review the outcome of the employee profit sharing plan.

Duty g: l expect auditors to inform works councils on internal organisation deficiencies.

The respondents were requested to answer on a five-point scale, coded as -2 if respondents strongly disagree with the proposition, coded as -1 if they disagree with it, coded as 0 if they are neutral, coded as +1 if they agree with it, and coded as +2 if they strongly agree with it. There was an additional opportunity to tick "no opinion/unable to judge". Table 6.9 presents the descriptive statistics.

Table 6.9: The standards gap: theoretical range, mean, median, standard deviation, $\%<0, \%>0, z$-score and number of observations.

\begin{tabular}{lcccccccc}
\hline Duty & $\begin{array}{c}\text { Theoretical } \\
\text { range }\end{array}$ & Mean & Median & $\begin{array}{c}\text { Standard } \\
\text { deviation }\end{array}$ & $\%<0$ & $\%>0$ & $\begin{array}{c}\text { z-score } \\
\text { median } \neq 0\end{array}$ & $N$ \\
\hline$d$ & -2 to +2 & 1.17 & 2.00 & 1.18 & 10.7 & 77.7 & $-6.470^{\circ}$ & 103 \\
e & -2 to +2 & 0.86 & 1.00 & 1.33 & 17.8 & 67.3 & $-5.002^{\circ}$ & 101 \\
f & -2 to +2 & 0.72 & 1.00 & 1.54 & 24.3 & 66.0 & $-3.743^{\circ}$ & 103 \\
g & -2 to +2 & 0.60 & 1.00 & 1.57 & 27.9 & 57.7 & $-3.429^{\circ}$ & 104 \\
\hline
\end{tabular}

Duty d: to audit interim accounts: Duty e: to discuss the company's financial position with the works council; Duty t: to review the outcome of the employee profit sharing plan; Duty g: to inform works councils on internal organisation deficiencies; one-sample Wilcoxon signed ranks z-scores; $\varphi$ significant at the 1 per cent level (all 2-tailed).

Table 6.9 shows that that the mean and median scores of all four Duties are positive and significantly different from zero (one-sample Wilcoxon signed ranks test z-scores running from -3.429 to -6.470 , all sign. [2-tailed]: 0.000$)^{14}$. Furthermore, the percentage of respondents who want auditors to perform these four duties runs from $57.7 \%$ to $77.7 \%$. This suggests that based on all decision rules these four duties contribute to the standards gap. 
Note that for Duty $d$ to Duty $f$ the number of observations is less than 104. This is due to missing observations of the dependent variables.

\subsubsection{Univariate results}

Table 6.10 presents the univariate results. It contains the non-parametric correlation coefficients between the dependent variables (Duty d, Duty e, Duty f and Duty g) and the independent variables. Only bargaining level is marginally significant in explaining the variation in Duty $\mathrm{d}$. A closer analysis shows that CL-bargainers more strongly expect auditors to audit interim accounts than do IL-bargainers. The remaining correlations are not significant. $\mathrm{Hl}$ is marginally supported, though only in partial analysis.

Table 6.10: The standards gap: univariate results: Mann-Whitney z-scores (LEVEL, TUA) and Spearman correlation coefficients (TEN, EDUC).

\begin{tabular}{lcrrr}
\hline & H1: LEVEL & H2: TUA & \multicolumn{1}{c}{ H3: TEN } & H4: EDUC \\
\hline Duty d & $1.914[p=0.056]$ & $-1.385[p=0.166]$ & $-0.052[p=0.601]$ & $0.061[p=0.541]$ \\
Duty e & $-0.400[p=0.689]$ & $0.371[p=0.711]$ & $0.039[p=0.700]$ & $0.093[p=0.357]$ \\
Duty $f$ & $-0.601[p=0.548]$ & $-0.480[p=0.631]$ & $-0.146[p=0.143]$ & $0.142[p=0.155]$ \\
Duty g & $-0.393[p=0.694]$ & $-0.683[p=0.494]$ & $-0.063[p=0.530]$ & $0.119[p=0.230]$ \\
\hline
\end{tabular}

LEVEL: $1=\mathrm{CL}, 0=\mathrm{IL}$; TUA: $1=\mathrm{FNV}, 0=$ otherwise; all test results are 2-tailed.

\subsubsection{Multivariate results}

The following models will be tested:

Duty $d=\beta_{0}+\beta_{1}$ LEVEL $+\beta_{2}$ TUA $+\beta_{3}$ TEN $+\beta_{4} E D U C+\epsilon$

Duty e =

$\beta_{0}+\beta_{1} L E V E L+\beta_{2}$ TUA $+\beta_{3}$ TEN $+\beta_{4} E D U C+\epsilon$

Duty $f=$

$\beta_{0}+\beta_{1} L E V E L+\beta_{2}$ TUA $+\beta_{3}$ TEN $+\beta_{4} E D U C+\epsilon$

Duty $g=$

$\beta_{0}+\beta_{1} L E V E L+\beta_{2}$ TUA $+\beta_{3}$ TEN $+\beta_{4} E D U C+\epsilon$

These variables are defined as follows:

Duty d: I expect auditors to audit the interim accounts (scale -2 to $2:-2=$ strongly disagree; $2=$ strongly agree).

Duty e: l expect auditors to discuss the company's financial position with the works council (scale -2 to 2 : $-2=$ strongly disagree; $2=$ strongly agree).

Duty f: lexpect auditors to review the outcome of the employee profit sharing plan (scale -2 to 2: $2=$ strongly disagree; $2=$ strongly agree).

Duty g: lexpect auditors to inform works councils on internal organisation deficiencies (scale -2 to 2: $-2=$ strongly disagree; $2=$ strongly agree).

LEVEL: Dummy variable indicating level of collective wage bargaining ( $1=\mathrm{CL}$-bargaining, $0=\mathrm{IL}$ bargaining).

TUA: Dummy variable indicating trade union affiliation ( $1=F N V, 0=0$ therwise $)$.

TEN: Length of tenure as a trade union bargainer (in years). 
EDUC: Level of education of the trade union bargainer (scale 1 to $12: 1=$ low; $12=$ high).

Table 6.11 presents the results.

Table 6.11: Multivariate results: Model 6.4 to 6.7 .

\begin{tabular}{lllllll}
\hline $\begin{array}{l}\text { Variable } \\
\text { Model 6.4: }\end{array}$ & Coefficient & Predicted sign & Value & Standard error & t-value & p-value (2-t) \\
\hline \multicolumn{7}{l}{ Moditing interim accounts. } \\
\hline Constant & $\beta_{0}$ & $(?)$ & 0.964 & 0.656 & 1.470 & 0.145 \\
LEVEL & $\beta_{1}$ & $(?)$ & 0.588 & 0.256 & 2.302 & 0.024 \\
TUA & $\beta_{2}$ & $(?)$ & -0.630 & 0.625 & -0.101 & 0.316 \\
TEN & $\beta_{3}$ & $(?)$ & 0.011 & 0.018 & 0.606 & 0.545 \\
EDUC & $\beta_{4}$ & $(?)$ & 0.012 & 0.043 & 0.271 & 0.787 \\
\hline
\end{tabular}

F-value $=1.384 ;$ sign. $0.230 ;$ adj. $R 2: 0.024 ; \mathrm{N}=96$.

\begin{tabular}{lllllll}
\hline Model 6.5: Duty e: Discussing the company's financial position with the works council. \\
\hline Constant & $\beta_{6}$ & $(?)$ & -0.002 & 0.873 & -0.002 & 0.998 \\
LEVEL & $\beta_{1}$ & $(?)$ & -0.040 & 0.304 & 0.132 & 0.896 \\
TUA & $\beta_{2}$ & $(?)$ & 0.278 & 0.824 & 0.338 & 0.736 \\
TEN & $\beta_{3}$ & $(?)$ & 0.009 & 0.020 & 0.455 & 0.650 \\
EDUC & $\beta_{6}$ & $(?)$ & 0.076 & 0.051 & 1.498 & 0.138 \\
\hline
\end{tabular}

F-value $=0.849 ;$ sign. $0.535 ;$ adj. $R 2:-0.010 ; \mathrm{N}=94$.

\begin{tabular}{lllllrl}
\hline Model 6.6: Duty & $\mathbf{f}$ Reviewing the outcome of the employee profit sharing plan. \\
\hline Constant & $\beta_{0}$ & $(?)$ & 0.845 & 0.863 & 0.979 & 0.330 \\
LEVEL & $\beta_{1}$ & $(?)$ & -0.269 & 0.336 & -0.800 & 0.426 \\
TUA & $\beta_{2}$ & $(?)$ & 0.238 & 0.822 & 0.290 & 0.773 \\
TEN & $\beta_{3}$ & $(?)$ & -0.043 & 0.023 & -1.833 & 0.070 \\
EDUC & $\beta_{4}$ & $(?)$ & -0.068 & 0.057 & 1.198 & 0.234 \\
\hline
\end{tabular}

F-value $=1.287 ;$ sign, $0.271 ;$ adj. $R 2: 0.018: \mathrm{N}=94$.

\begin{tabular}{lllllll}
\hline Model 6.7: Duty & g: Informing & works councils on internal organisation deficiencies. \\
\hline Constant & $\beta_{0}$ & $(?)$ & 0.173 & 0.914 & 0.190 & 0.850 \\
LEVEL & $\beta_{1}$ & $(?)$ & -0.144 & 0.356 & -0.404 & 0.687 \\
TUA & $\beta_{2}$ & $(?)$ & -0.489 & 0.871 & -0.562 & 0.576 \\
TEN & $\beta_{3}$ & $(?)$ & 0.018 & 0.025 & 0.762 & 0.448 \\
EDUC & $\beta_{4}$ & $(?)$ & 0.075 & 0.060 & 1.252 & 0.214 \\
\hline
\end{tabular}

F-value $=0.649 ;$ sign. $0.691 ;$ adj. $\mathrm{R} 2:-0.022: \mathrm{N}=97$.

LEVEL: $1=\mathrm{CL}, 0=1 \mathrm{~L}:$ TUA: $1=\mathrm{FNV}, 0=$ otherwise; all test results are 2 -tailed.

Table 6.11 summarises the results from Model 6.4 to 6.7. In Model 6.4 the parameter bargaining level is positive and significant for conventional levels of significance, suggesting that CL-bargainers significantly more strongly expect auditors to audit interim accounts than do IL-bargainers. In Model 6.6 the parameter of length of tenure as a trade union bargainer is negative and marginally significant. This suggests that the less experienced trade union bargainers tend more strongly to expect auditors to review the outcome of the employee profit sharing plan, than do the more experienced bargainers. Note that none of the models is statistically significant. 


\subsubsection{Concluding remarks on research question 2}

On average, the respondents expect auditors to perform all four duties as suggested. We are not particularly successful in explaining the variation of the dependent variables. Bargaining level is marginally significant in the univariate analysis (Duty d), and significant in the multivariate analysis (Duty d). In the multivariate analysis, length of tenure as a trade union bargainer is marginally significant (Duty $\mathrm{f}$ ). At the multivariate level, none of the four models is significant. Overall, there is some limited support for $\mathrm{H} 2$ and $\mathrm{H} 3$, again only in partial analyses.

\subsection{The reasonableness gap: empirical results}

\subsubsection{The dependent variable: REASONGAP}

The reasonableness gap of bargainer i can be defined as the extent to which bargainer i expects auditors to conduct duties that cannot reasonably be expected of auditors. The reasonableness gap of bargainer $\mathrm{i}$ with regard to Duty $\mathrm{z}$ can take three forms:

1. REASONGAP $\mathrm{iz}<0$ : bargainer $i$ does not expect auditors to conduct Duty $z$

2. REASONGAP ${ }_{i z}=0$ : bargainer $i$ is neutral about whether auditors should conduct Duty $z$

3. REASONGAP ${ }_{i z}>0$ : bargainer i does expect auditors to conduct Duty $z$

The respondents were asked to indicate the extent to which they support each of the following three propositions.

Duty h: I expect auditors to measure the efficiency and effectiveness of management and to report on this.

Duty i: I expect auditors to audit for compliance with the ARBO-Law (Law on Labour Conditions). ${ }^{15}$

Duty j: I expect auditors to audit the company's impact on the local environment.

The respondents were requested to answer on a five-point scale, coded as -2 if respondents strongly disagree with the proposition, coded as -1 if they disagree with it, coded as 0 if they are neutral, coded as +1 if they agree with it, and coded as +2 if they strongly agree with it. There was an additional opportunity to tick "no opinion/unable to judge". Table 6.12 presents the descriptive statistics. 
Table 6.12: The reasonableness gap: theoretical range, mean, median, standard deviation, $\%<0$ and $\%>0, z$-score and number of observations.

\begin{tabular}{lcccccccc}
\hline Duty & $\begin{array}{c}\text { Theoretical } \\
\text { range }\end{array}$ & Mean & Median & $\begin{array}{c}\text { Standard } \\
\text { deviation }\end{array}$ & $\%<0$ & $\%>0$ & $\begin{array}{c}\text { z-score } \\
\text { median } \neq 0\end{array}$ & $\mathbf{N}$ \\
\hline $\mathrm{h}$ & -2 to +2 & -0.74 & -1.00 & 1.54 & 67.3 & 23.8 & $-3.936^{\circ}$ & 101 \\
$i$ & -2 to +2 & 0.01 & 0.00 & 1.42 & 36.3 & 32.4 & -0.263 & 102 \\
& -2 to +2 & -0.80 & -1.00 & 1.24 & 63.7 & 13.7 & $-5.083^{\circ}$ & 102 \\
\hline
\end{tabular}

Duty $h$ : to audit the efficiency and effectiveness of management and to report on this; Duty $i$ : to audit for compliance with the ARBO-Law (Law on Labour Conditions); Duty i: to audit the company's impact on the local community; onesample Wilcoxon signed ranks z-scores; $\varphi$ significant at the 1 per cent level (2-tailed).

Table 6.12 shows that that the mean and median scores of Duty $\mathrm{h}$ and Duty $\mathrm{j}$ are negative and significantly different from zero (one-sample Wilcoxon signed ranks test z-scores: -3.936 and -5.083 , all sign. [2-tailed]: 0.000$)^{16}$. The mean score of Duty $i$ is close to zero $(0.01)$ while the median score is not significant from zero for conventional levels of significance (one-sample Wilcoxon signed ranks test z-score: -0.263 , sign. [2-tailed]: 0.795$)^{17}$. The percentage of respondents who want auditors to perform Duty h to Duty j runs from are $13.7 \%$ to $32.4 \%$. This suggests that these three

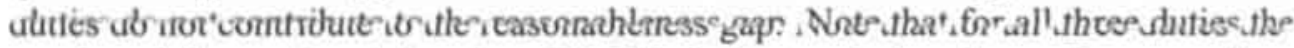
number of observations is less than 104 . This is due to missing observations regarding the dependent variables.

\subsubsection{Univariate results}

Table 6.13 below presents the univariate results. It presents the non-parametric correlation coefficients between Duty h, Duty i, Duty j and the independent variables. The table shows that the correlation between Duty $\mathrm{h}$ and bargaining level, trade union affiliation and the trade union bargainer's level of education are (marginally) significant. A closer analysis makes clear that IL-bargainers, non-FNV-bargainers and more experienced trade union bargainers more strongly expect auditors to perform Duty $h$. The remaining correlations are not statistically significant.

Table 6.13: The reasonableness gap: univariate analyses: Mann-Whitney z-scores (LEVEL, TUA) and Spearman correlation coefficients (TEN, EDUC).

\begin{tabular}{lcccc}
\hline & H1: LEVEL & H2: TUA & H3: TEN & H4: EDUC \\
\hline Duty h & $-2.229[p=0.026]$ & $-2.097[p=0.036]$ & $0.093[p=0.356]$ & $0.178[p=0.076]$ \\
Duty i & $-0.984[p=0.325]$ & $-1.498[p=0.134]$ & $0.070[p=0.485]$ & $0.054[p=0.589]$ \\
Duty $j$ & $-0.373[p=0.709]$ & $-0.921[p=0.357]$ & $0.099[p=0.323]$ & $0.057[p=0.573]$ \\
\hline
\end{tabular}

LEVEL: $1=\mathrm{CL}, 0=I \mathrm{~L}:$ TUA: $1=\mathrm{FNV}, 0=$ otherwise; all test results are 2 -tailed. 


\subsubsection{Multivariate results}

The following models will be tested:

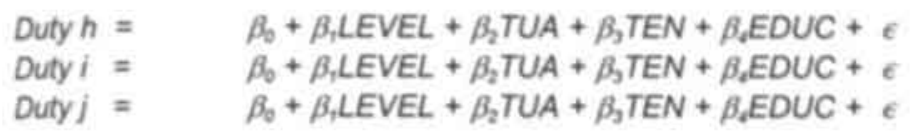

These variables are defined as follows:

Duty h: $\quad$ l expect auditors to measure the efficiency and effectiveness of management and to report on this (scale -2 to 2:-2=strongly disagree; 2=strongly agree).

Duty i: I expect auditors to audit for compliance with the ARBO-Law (Law on Labour Conditions) (scale -2 to $2:-2=$ strongly disagree; 2 =strongly agree).

Duty i: I expect auditors to audit the company's impact on the local community and environment (scale -2 to $2:-2=$ strongly disagree; $2=$ strongly agree).

LEVEL: Dummy variable indicating level of collective wage bargaining ( $1=\mathrm{CL}$-bargaining. $0=\mathrm{lL}$. bargaining).

TUA. Dummy variable indicating trade union affiliation ( $1=F N V, 0=0$ therwise).

TEN: Length of tenure as a trade union bargainer (in years),

EDUC: Level of education of the trade union bargainer (scale 1 to 12:1=low, 12=high).

The correlation of the independent variables were presented in Table 6.7. Based on that table we concluded that multicollinearity does not pose a problem. Table 6.14 presents the multivariate results.

Table 6.14: Multivariate results: Model 6.8 to 6.10 .

\begin{tabular}{lllllll}
\hline Variable & Coefficient & Predicted sign & Value & Standard error & t-value & $p$-value (2- $t)$ \\
\hline Model 6.8: Duty $\mathrm{h}$ : To audit the efficiency and effectiveness of management and to report on this. \\
\hline Constant & $\beta_{0}$ & $(?)$ & -1.072 & 0.801 & -1.339 & 0.184 \\
LEVEL & $\beta_{1}$ & $(?)$ & -0.392 & 0.313 & -1.254 & 0.213 \\
TUA & $\beta_{2}$ & $(?)$ & -1.886 & 0.762 & -2.475 & 0.015 \\
TEN & $\beta_{3}$ & $(?)$ & -0.056 & 0.022 & -2.567 & 0.012 \\
EDUC & $\beta_{4}$ & $(?)$ & 0.164 & 0.053 & 3.074 & 0.003 \\
\hline
\end{tabular}

F-value $=4.540 ;$ sign. $0.000 ;$ adj. R2: $0.186 ; \mathrm{N}=94$

Model 6.9: Duty i: Auditing for compliance with the ARBO-Law (Law on Labour Conditions).

\begin{tabular}{lllrrrr}
\hline Constant & $\beta_{0}$ & $(?)$ & -0.332 & 0.786 & -0.422 & 0.674 \\
LEVEL & $\beta_{1}$ & $(?)$ & 0.488 & 0.311 & 1.568 & 0.120 \\
TUA & $\beta_{2}$ & $(?)$ & -1.068 & 0.752 & -1.420 & 0.159 \\
TEN & $\beta_{3}$ & $(?)$ & 0.039 & 0.022 & 1.805 & 0.075 \\
EDUC & $\beta_{4}$ & $(?)$ & 0.036 & 0.052 & 0.695 & 0.489
\end{tabular}

F-value $=2.012 ;$ sign. $0.072 ;$ adj. $R 2: 0.061 ; \mathrm{N}=95$.

Model 6.10: Duty j: Auditing the company's impact on the local community and environment.

\begin{tabular}{lllrrrr}
\hline Constant & $\beta_{0}$ & $(?)$ & -0.703 & 0.666 & -1.056 & 0.294 \\
LEVEL & $\beta_{1}$ & $(?)$ & -0.025 & 0.264 & -0.095 & 0.925 \\
TUA & $\beta_{2}$ & $(?)$ & -1.373 & 0.638 & -2.153 & 0.034 \\
TEN & $\beta_{3}$ & $(?)$ & 0.052 & 0.018 & 2.866 & 0.005 \\
EDUC & $\beta_{4}$ & $(?)$ & 0.062 & 0.044 & 1.407 & 0.163 \\
\hline
\end{tabular}

F-value $=2.394 ;$ sign. $0.034 ;$ adj. $R 2 ; 0.082 ; \mathrm{N}=95$.

LEVEL: $1=C L$, $0=I L:$ TUA: $1=F N V, 0=0$ therwise; all test results are 2-tailed. 
Table 6.14 summarises the results from Models 6.8 to 6.10. In Model 6.8, trade union affiliation, length of tenure as a trade union bargainer and level of education of the trade union bargainer are significant, indicating that FNV-bargainers, more experienced bargainers and less educated bargainers less strongly expect auditors to audit the efficiency and effectiveness of management and to report on this. Length of tenure as a trade union bargainer is positive and marginally significant in Model 6.9. This indicates that more experienced bargainers more strongly expect auditors to audit for compliance with the ARBO-Law than do other bargainers. In Model 6.10, trade union affiliation and length of tenure as a trade union bargainer are significant. FNV. bargainers less strongly expect auditors to audit the company's impact on the local community and environment than do other bargainers. Also, more experienced trade union bargainers significantly more strongly expect auditors to audit the company's impact on the local community and environment than do less experienced bargainers. Model 6.9 is marginally significant; the other two models are significant. The explanatory power of the models runs from $6.1 \%$ to $18.6 \%$.

\subsubsection{Concluding remarks on research question 3}

On average, the respondents do not expect auditors to perform any of the three duties that cannot reasonably be expected of auditors. Bargaining level was significant in the univariate analysis (Duty h) but not in the multivariate analysis. Trade union affiliation was significant in both the univariate analysis (Duty h) and multivariate analysis (Duty h). Length of tenure as a trade union bargainer was not significant in the univariate analysis, but (marginally) significant in the multivariate analysis (Duty $h, i$, and j). The level of education of the trade union bargainer was marginally significant in the univariate analysis (Duty h) and significant in the multivariate analysis (Duty h). The results are mixed and provide tentative support for all four hypotheses, though only in partial analysis.

\subsection{Summary and overall conclusions}

This chapter addresses the research question "Do trade union bargainers have an audit expectations gap, and if so, what explains the variation in the gap? To answer the question, the AEG was split into three components, which in turn were split into a number of auditor duties. The results are based on the views of 104 trade union bargainers in the Netherlands. With regard to existing auditor duties, we asked the respondents to give their views on how well auditors perform these duties. The performance of two of the three duties (Duty b and Duty c, see Section 6.6.1) is perceived to be below standard. Both duties are related to the auditor's role as 
"corporate watchdog". We also found a standards gap with regard to the four duties proposed (Duty d,e,f,g, See Section 6.7.1), suggesting that trade union bargainers want auditors to perform these duties. A reasonableness gap was not found for the group as a whole; however, up to almost one-third of the respondents expect auditors to perform duties that cannot reasonably be expected of auditors.

The results are in line with the findings reported by the Limperg Institute (1987). They found that the auditors' performance of reporting going concern problems to third parties is perceived as substandard by $40 \%$ of the respondents. Similar results are found on reporting internal organisation deficiencies to management and members of the board of supervisors. We also find evidence indicating that the performance of these two duties is considered substandard.

The findings reported in this chapter partly confirm the findings of Porter (1993). As in Porter, we found no gap with regard to the performance of statutory audits. Furthermore, Porter also found that auditing interim accounts is perceived to be deficient.

However, there is also an important difference between the findings presented here and those presented by Porter. She reported the existence of a reasonableness gap, while we found no evidence for the existence of such a gap. One possible reason for this difference is that we used a different boundary to conclude that an interest group expects the auditor to conduct a non-existing duty (rule: $33.3 \%$ of the respondents) than Porter did (rule: $20.0 \%$ of the respondents). If we had used the decision rule from Porter, our conclusions would slightly change. The evidence for the existence of an reasonableness gap with regard to one of the duties would be inconclusive, while we concluded that no evidence was found indicating this gap. ${ }^{18}$

Possible further explanations for the observed difference in this study and that of Porter is that Porter's group of respondents is more diverse, ${ }^{19}$ that there are differences in the setting of the two studies, and that different auditor duties are proposed. It is possible that due to differences in the status of the auditing profession, due to institutional differences, and due to press coverage of financial scandals involving auditors, the users of auditor's reports in New Zealand have different expectations and perceptions of auditors than do users of auditor's reports in the Netherlands.

We tried to explain the variation in the observed gaps by investigating the explanatory power of four independent variables. Our main variable is bargaining level (LEVEL). The impact of three control variables is also tested: trade union affiliation (TUA), length of tenure as a trade union bargainer (TEN), and level of the trade union bargainer's education (EDUC). Table 6.18 summarises the significance of the 
independent variables.

Table 6.18: Summary of the significance of the independent variables: univariate and multivariate results $(\mathrm{N}=104)$.

\begin{tabular}{|c|c|c|c|c|c|c|c|c|}
\hline \multirow[t]{2}{*}{ 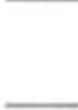 } & \multirow[t]{2}{*}{ Gap } & \multirow[t]{2}{*}{ Duty } & \multirow{2}{*}{$\begin{array}{c}\text { Gap } \\
?\end{array}$} & \multirow[t]{2}{*}{ Analysis } & \multicolumn{4}{|c|}{ Significance of the independent variables } \\
\hline & & & & & $\begin{array}{c}\text { H1 } \\
\text { LEVEL }\end{array}$ & $\begin{array}{l}\mathrm{H} 2 \\
\text { TUA }\end{array}$ & $\begin{array}{l}\text { H3 } \\
\text { TEN }\end{array}$ & $\begin{array}{c}\mathrm{H} 4 \\
\text { EDUC }\end{array}$ \\
\hline \multirow{10}{*}{$\mathrm{AEG}$} & \multirow{3}{*}{ PERFGAP } & a & no & $\begin{array}{l}\text { univariate } \\
\text { multivariate }\end{array}$ & & & $\cdot$ & \\
\hline & & b & yes & $\begin{array}{l}\text { univariate } \\
\text { multivariate }\end{array}$ & & & & $\cdot$ \\
\hline & & c & yes & $\begin{array}{l}\text { univariate } \\
\text { multivariate }\end{array}$ & & & & \\
\hline & \multirow{4}{*}{ STANDGAP } & d & yes & $\begin{array}{l}\text { univariate } \\
\text { multivariate }\end{array}$ & $\dot{*}$ & & & \\
\hline & & e & yes & $\begin{array}{l}\text { univariate } \\
\text { multivariate }\end{array}$ & & & & \\
\hline & & $f$ & yes & $\begin{array}{l}\text { univariate } \\
\text { multivariate }\end{array}$ & & & $\cdot$ & \\
\hline & & 9 & yes & $\begin{array}{l}\text { univariate } \\
\text { multivariate }\end{array}$ & & & & \\
\hline & \multirow{3}{*}{ REASONGAP } & h & no & $\begin{array}{l}\text { univariate } \\
\text { multivariate }\end{array}$ & $*$ & $\ddot{*}$ & $*$ & $\dot{*}$ \\
\hline & & i & no & $\begin{array}{l}\text { univariate } \\
\text { multivariate }\end{array}$ & & & $\cdot$ & \\
\hline & & j & no & $\begin{array}{l}\text { univariate } \\
\text { multivariate }\end{array}$ & & $*$ & $\cdots$ & \\
\hline
\end{tabular}

AEG: audit expectations gap; PERFGAP: performance gap; STANDGAP: standards gap; REASONGAP: reasonableness gap: LEVEL: $1=\mathrm{CL}, 0=\mathrm{IL} ;$ TUA: $1=\mathrm{FNV}, 0=$ otherwise; $\cdots$ significant at the $1 \%$-level; "* significant at the $5 \%$-level; ${ }^{*}$ significant at the $10 \%$-level; all results 2 -tailed.

We were more successful in explaining the variation of the duties that form the reasonableness gap. Overall, the explanatory power of the independent variables considered is limited. The power of bargaining level, our main independent variable, is low. The three control variables are significant only in partial analysis, and especially with regard to explaining the variation in the duties that form the reasonableness gap.

Limitations, policy implications and research opportunities following from this chapter will be discussed in Chapter 8 of this dissertation. 


\section{Appendix 6A: Relevant part of the questionnaire}

Table 6.19 summarises the relevant questions of the questionnaire. The introduction of the questionnaire explained that the focus was on the duties of public registered auditors ("registeraccountants werkzaam voor een accountantskantoor"), and the respondents were asked to provide answers with reference to these auditors only.

Table 6.19: Relevant part of the questionnaire.

\begin{tabular}{|c|c|c|}
\hline Variable & Original questions (in Dutch) & Translation of the question \\
\hline Duty a & $\begin{array}{l}\text { Accountants slagen er in de praktijk in } \\
\text { voldoende mate in te waarborgen dat } \\
\text { jaarrekeningen goede en adequate } \\
\text { informatie geven. }\end{array}$ & $\begin{array}{l}\text { Auditors are sufficiently successful in } \\
\text { conducting statutory audits. [5-point scale: } \\
-2=\text { strongly agree [perceived performance } \\
\text { is above expectations] to }+2 \text { = strongly } \\
\text { disagree [perceived performance is below } \\
\text { expectations] }\end{array}$ \\
\hline Duty b & $\begin{array}{l}\text { Accountants slagen er in de praktijk in } \\
\text { voldoende mate in het gevaar voor het } \\
\text { voortbestaan van ondernemingen tijdig naar } \\
\text { buiten te brengen. }\end{array}$ & $\begin{array}{l}\text { Auditors are sufficiently successful in } \\
\text { reporting going concern problems to } \\
\text { outsiders. [5-point scale: }-2=\text { strongly } \\
\text { agree to }+2=\text { strongly disagree] }\end{array}$ \\
\hline Duty c & $\begin{array}{l}\text { Accountants slagen er in de praktijk in } \\
\text { voldoende mate in een gebrekkige kwaliteit } \\
\text { van organisaties tijdig te melden aan de } \\
\text { toporganen (commissarissen en bestuur). }\end{array}$ & $\begin{array}{l}\text { Auditors are sufficiently successful in } \\
\text { informing the management and board of } \\
\text { supervisors on internal organisation } \\
\text { deficiencies. [scale see Duty b] }\end{array}$ \\
\hline Duty d & $\begin{array}{l}\text { lk verwacht van accountants dat zij } \\
\text { tussentijdse financiële overzichten (half-jaar } \\
\text { berichten) controleren. }\end{array}$ & $\begin{array}{l}\text { I expect auditors to audit interim accounts. } \\
\text { [scale see Duty b] }\end{array}$ \\
\hline Duty e & $\begin{array}{l}\text { Ik verwacht van accountants dat zij de } \\
\text { financiële situatie van de onderneming met } \\
\text { de OR bespreken. }\end{array}$ & $\begin{array}{l}\text { I expect auditors to discuss the company's } \\
\text { financial position with the works council. } \\
\text { [scale see Duty b] }\end{array}$ \\
\hline Duty f & $\begin{array}{l}\text { Ik verwacht van accountants dat zij in } \\
\text { voorkomende gevallen de juistheid van de } \\
\text { uitvoering van winstdelingsregelingen } \\
\text { beoordelen. }\end{array}$ & $\begin{array}{l}\text { I expect auditors to review the outcome of } \\
\text { the employee profit sharing plan. [scale } \\
\text { see Duty b] }\end{array}$ \\
\hline Duty g & $\begin{array}{l}\text { Ik verwacht van accountants dat zij in } \\
\text { voorkomende gevallen de OR inlichten over } \\
\text { gebreken in de interne organisatie. }\end{array}$ & $\begin{array}{l}\text { I expect auditors to inform works councils } \\
\text { on internal organisation deficiencies. [scale } \\
\text { see Duty b] }\end{array}$ \\
\hline Duty h & $\begin{array}{l}\text { Ik verwacht van accountants dat zij de } \\
\text { effectiviteit en efficiëntie van de } \\
\text { ondernemingsleiding beoordelen en } \\
\text { daarover rapporteren. }\end{array}$ & $\begin{array}{l}\text { 1 expect auditors to measure the efficiency } \\
\text { and effectiveness of management and to } \\
\text { report on this. [scale see Duty b] }\end{array}$ \\
\hline Duty i & $\begin{array}{l}\text { Ik verwacht van accountants dat zij de } \\
\text { naleving van de ARBO-wet controleren. }\end{array}$ & $\begin{array}{l}\text { I expect auditors to audit for compliance } \\
\text { with the ARBO-Law (Law on Labour } \\
\text { Conditions). [scale see Duty b] }\end{array}$ \\
\hline Duty j & $\begin{array}{l}\text { Ik verwacht van accountants dat zij de } \\
\text { invloed van ondernemingen op hun directe } \\
\text { omgeving controleren. }\end{array}$ & $\begin{array}{l}\text { I expect auditors to audit the company's } \\
\text { impact on the local environment. } \\
\text { [scale see Duty b] }\end{array}$ \\
\hline LEVEL & $\begin{array}{l}\text { Bij welk type CAO-onderhandelingen bent u } \\
\text { hoofdzakelijk betrokken? } \\
\text {-op ondernemingsnivo; } \\
\text {-op bedrijfstaknivo; } \\
\text {-geen van beide. }\end{array}$ & $\begin{array}{l}\text { With what type of bargaining are you } \\
\text { mostly involved? -corporate-level } \\
\text { bargaining: } \\
\text {-industry-level bargaining: } \\
\text {-none [closed question] }\end{array}$ \\
\hline
\end{tabular}




\begin{tabular}{lll} 
TUA & Bij welke vakbondfederatie werkt u? & With which trade union are you affiliated? \\
\hline TEN & $\begin{array}{l}\text { Hoeveel jaar ervaring heeft } u \text { als } \\
\text { vakbondsonderhandelaar? }\end{array}$ & $\begin{array}{l}\text { How many years experience do you have } \\
\text { as a trade union bargainer? [open ended] }\end{array}$ \\
\hline EDUC & $\begin{array}{l}\text { Wat is uw vooropleiding? } \\
\text { (uw hoogst behaalde examen). }\end{array}$ & $\begin{array}{l}\text { What is your level of education? (your } \\
\text { highest degree). [12-point scale: } 1 \text { primary } \\
\text { school to 12: university degree/business } \\
\text { administration] }\end{array}$ \\
& &
\end{tabular}

The questions are presented in the same order as in the chapter. Note that this is not the original order of questions as presented to the trade union bargainers. 


\section{Appendix 6B: Test for non-response bias}

The test for non-response bias was performed by comparing the answers of the first 25 respondents (median number of days needed to return the questionnaire: 4 ) with the last 25 respondents (median number of days needed to return the questionnaire: 38). Table 6.20 below depicts the results.

Table 6.20: Mann-Whitney U-test for non-response bias (all results 2-tailed).

\begin{tabular}{|c|c|c|c|c|c|c|c|c|}
\hline \multirow[t]{2}{*}{ Variable } & \multicolumn{3}{|c|}{ Early respondents $(\mathrm{N}=25)$} & \multicolumn{3}{|c|}{ Late respondents $(\mathrm{N}=25)$} & \multirow[t]{2}{*}{ z-score } & \multirow[t]{2}{*}{ p-value } \\
\hline & Mean & Std & Median & Mean & Std & Median & & \\
\hline Days & 5.240 & 1.877 & 4.000 & 38.120 & 12.908 & 38.000 & -6.101 & 0.000 \\
\hline Duty a & -0.600 & 1.027 & -1.000 & -0.435 & 1.121 & 0.000 & -0.602 & 0.547 \\
\hline Duty b & 0.478 & 1.170 & 0.000 & -0.100 & 1.334 & 0.000 & $-1,402$ & 0.161 \\
\hline Duty c & 0.435 & 1.174 & 0.000 & 0.524 & 1.400 & 1.000 & -0.376 & 0.707 \\
\hline Duty od & 1.010 & 1.176 & 1.000 & 1.167 & 1.090 & 1.500 & -0.291 & 0.771 \\
\hline Duty e & 0.995 & 1.327 & 1.000 & 0.638 & 1.351 & 0.000 & -0.565 & 0.553 \\
\hline Duty $f$ & 0.292 & 1.537 & 1.000 & 0.520 & 1.418 & 1.000 & -0.371 & 0.711 \\
\hline Duty g & 0.720 & 1.567 & 1.000 & 0.250 & 1.424 & 1.000 & -1.327 & 0.191 \\
\hline Duty h & -0.640 & 1.541 & -1.000 & -1.000 & 1.383 & -2.000 & -0.734 & 0.463 \\
\hline Duty i & 0.083 & 1.425 & 0.000 & 0.000 & 1.354 & 0.000 & -0.185 & 0.853 \\
\hline Duty $j$ & -0.458 & 1.235 & 0.000 & -0.920 & 0.997 & -1.000 & $-1,446$ & 0.148 \\
\hline TEN & 9.860 & 7.222 & 8.000 & 7.177 & 4.615 & 6.000 & -0.963 & 0.336 \\
\hline EDUC & 7.917 & 2.701 & 9.000 & 7.560 & 2.987 & 9.000 & -0.399 & 0.690 \\
\hline
\end{tabular}

For questions and response scales see Table 6.19 in Appendix $6 \mathrm{~A}$ at the end of this chapter. 


\section{Notes}

1. See Flint (1988, p.11).

2. For instance, with regard to Bobel (Het Financieele Dagblad, 04-18-1997), Ceteco (Het Financieele Dagblad, 10-13-1999 and 07-24-1999), DAF (Het Financieele Dagblad, 12. 12-1997), De Vries Robbe (Het Financieele Dagblad, 11-20-1999), Chipshol (Het Financieele Dagblad, 12-05-1998), Heino Krause (Het Financieele Dagblad, 05-07-1999) Super Club (Het Financieele Dagblad, 12-09-1995), Verolme (Het Financieele Dagblad, 07-03-1999), Vie d'Or (Het Financieele Dagblad, 07-10-1998).

3. Westerlaken interviewed by Schilder (1994b, p.386). Original text in Dutch. DAF is a truck producing company located in Eindhoven in the southern part of the Netherlands. DAF was founded in 1928 and from 1949 on trucks were built. In 1989 DAF NV went public. After a few successful years, the company went bankrupt in 1993. The bad market situation in the United Kingdom and the bad debts portfolio of DAF Finance were due to the debacle. After the bankruptcy was filed, the company made a restart as DAF Trucks NV. In 1996 the shares of DAF Trucks NV were purchased by the United States based

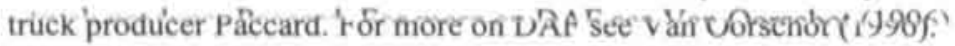

4. Here we follow Porter (1993).

5. Sec for instance Porter (1993) and Monroe and Woodcliff (1994).

6. Porter (1993) conducted a mail survey among auditors and non-auditors (auditees, users of auditor's reports and the audit beneficiaries/financial community). She found that 25 of the 30 suggested duties of auditors contribute to the AEG. Preparing the auditee's financial statements, and reporting the impact of the company on the local community were duties not expected of auditors. Of these 25 duties, seven contribute to the performance gap, eight to the standards gap and ten to the reasonableness gap.

7. The main point is that in some companies, trade unions bargain directly with executive management (corporate-level bargaining or CL-bargaining) and in other companies, trade unions bargain with representatives of companies within the industry (industry-level bargaining or IL-bargaining).

8. The questionnaire is available from the author on request.

9. The questionnaires were sent between December 1994 and May 1995. After three weeks, subjects received a reminder.

10. See also Chapter 5 of this dissertation.

11. The study of the Limperg Institute had an overall response rate of $49 \%$. The response rates of the study of Humprey et al. (1993) run from $17.3 \%$ to $73.2 \%$. Porter (1993) reported response rates between the $60 \%$ and $90 \%$. 
12. Note that the median score for Duty a in Table 6.5 is 0.000 . Nonetheless the median score based on the one-sample Wilcoxon signed ranks test is negative and significant from 0 . This is due to the fact that the one-sample Wilcoxon signed ranks test first deletes zero values from the dataset and then redefines $\mathrm{N}$ to the number of nonzero observation (see also Hollander and Wolf, 1999, p.67).

13. Additionally we performed a one-sample t-test to see whether the mean score is significantly different from 0 . The results indicate that the mean score is negative and significant different from 0 for conventional levels of significance (t-score: - 3.953; sign. [2-tailed]: 0.000).

14. Additionally we performed a series of one-sample t-tests to see whether the mean scores of Duty $d$ to Duty g are significantly different from 0 . The results indicate that the mean scores are all positive and significant different from 0 for conventional levels of significance (t-scores running from : -3.879 to -10.146 ); all sign. [2-tailed]: 0.000 ).

15. The ARBO-Law (Law on Labour Conditions: Arbeidsomstandighedemwet, 1998) contains the rights and obligations of employers and employees with regard to working conditions, including working hours, breaks, health and safety issues. It is mandatory for employers to comply with this law.

16. Additionally we performed two one-sample t-tests to see whether the mean scores of Duty $\mathrm{h}$ to Duty $\mathrm{j}$ are significantly different from 0 . The results indicate that the mean scores are all negative and significant different from 0 for conventional levels of significance ( $t$ scores running from : -4.844 to -6.574 ); all sign. [2-tailed]: 0.000 ).

17. Additionally we performed a one-sample t-tests to see whether the mean scores of Duty $\mathrm{i}$ is significantly different from 0 . The results indicate that the mean score is not significant different from 0 for conventional levels of significance (t-score: 0.070 ; sign. [2-tailed]: 0.945).

18. This concerns Duty h: "I expect auditors to measure the efficiency and effectiveness of management and to report on this".

19. The respondents included auditees, bankers, and the public in general, which may have different expectations than trade union bargainers. 


\section{Chapter 7 \\ The Independence of Auditors: \\ A study among trade union bargainers}

\section{$7.1 \quad$ Introduction}

This chapter is concerned with auditor independence (AI). We will investigate the existence and variation of the auditor independence gap (AIG). As the audit expectations gap (see Chapter 6), the AIG can be defined as the gap between the public's expectations of $\mathrm{AI}$ and the public's perceptions of actual $\mathrm{AI}$. ${ }^{1}$ We will use the research approach of Chapter 6 to investigate the AIG.

Independence is one of the most important professional requirements of auditors. ${ }^{2}$ The literature typically distinguishes between actual $\mathrm{AI}$ and the appearance of $\mathrm{AI}$, as do Arens and Loebbecke (2000, pp.86-87):

"the value of auditing depends heavily on the public's perception of the independence of auditors (...). Not only is it essential for auditors to maintain an independent attitude in fulfilling their responsibility, but it is also important that the users of financial statements have confidence in that independence (...). If auditors are independent in fact, but users believe them to be advocates for the client, most of the value of the audit function will be lost".

The auditing profession has basically a self-regulatory position in safeguarding AI. Over the years, the Dutch national organisation of auditors, NIVRA, has taken several steps to strengthen AI, for instance by establishing a Code of Professional Conduct (NIVRA, 1995). ${ }^{3}$ The Code explicitly demands AI, and contains several restrictions to strengthen it. ${ }^{4}$ Some controversial issues, however, are not regulated. For example, no restrictions are imposed on rendering management advisory services to audit clients, and there are no limitations as to the period auditors can serve a particular audit client. Current developments, including increased competition among audit firms, the trend of clients to cut audit costs, and the increased provision of management advisory services, increase concern about the above threats to AI.

Previous empirical research in the Anglo-Saxon world as well as in the Netherlands focused on the public's expectations of AI. $^{5}$ However, so far the AIG of trade union 
bargainers has not been investigated. This chapter aims to extend previous research by investigating the perceptions of trade union bargainers regarding AI.

The central research question of this chapter is:

What are trade union bargainers' perceptions of auditor independence and what explains the variation in these perceptions?

The setting is the Netherlands. Detailed hypotheses will be developed below. This chapter is organised as follows. Section 7.2 presents the theoretical framework. Section 7.3 provides a brief overview of the relations to previous empirical research. Section 7.4 develops the hypotheses. Section 7.5 presents the research design and discusses the characteristics of the respondents. Section 7.6 presents the empirical results. Finally, Section 7.7 provides a summary and overall conclusions.

Table 7.1 shows how the empirical part of the chapter is composed.

Table 7.1: The composition of the empirical part of this chapter.

\begin{tabular}{llc}
\hline Dependent variable & Analysis & Section \\
\hline Auditor independence gap (AIG) & univariate & 7.6 .2 \\
& multivariate & 7.6 .3 \\
\hline
\end{tabular}

Note that internal auditors, by nature of their relationship with the company, are not independent from executive management. Therefore this chapter focuses only on public registered (external) auditors ("openbare registeraccountants").

\subsection{Theoretical framework}

Previous studies found that corporate annual reports are used for general orientation and for specific decision making. ${ }^{6}$ In both cases, the usefulness of the information depends on its credibility. As was explained in detail in Chapter 2, contracting cost theory believes companies have incentives to engage in costly activities to signal credibility. This is a potential market for the providers of independent audits. Independent audits may serve as a monitoring device and arbitration mechanism on the accounting technology used by the company.

The success of auditors in increasing the credibility of accounting information depends on their reputation, which in turn is based on their ability to detect material errors, and on their willingness to demand adjustments. The first depends on the auditors' competence, the latter on the extent to which auditors are independent from management. To create a demand for audit services, auditors have to convince the market that they are both competent and independent. According to Wines 
(1994, p. 77) "the auditor's reputation serves as a collateral bond for independence, in that the reputation of an auditor found to be less independent than expected will be damaged and the present value of his/her audit services will be reduced".

A rational auditor, then, is likely to weigh the gains of collusion from a compromised auditor's report against the impact on the auditor's reputation when it becomes public. ${ }^{7}$

Chapter 5 of this dissertation found that trade union bargainers use corporate annual reports to get an overall impression of the company. In management-trade union contracting, management may also have incentives to lower agency costs by signalling the credibility of the information presented. Due to measurements problems and to information asymmetry, trade union bargainers are not able to observe actual AI, but they do have perceptions of it.

When the trade union bargainers' perceived level of AI is below the expected level of AI, the auditor's reputation as independent expert is under threat.

\subsection{Relations to previous empirical research}

$\mathrm{AI}$ is a complex issue that has received much attention in the empirical literature. ${ }^{8}$ Previous empirical studies focused on a diverse set of users of auditor's reports, and addressed the impact of various threats to AI. Schilder (1994c, pp.99-111) provides an extensive review of this literature. More recent overviews on $\mathrm{AI}$ are provided in Gorman et al. (2000), Sucher et al. (2000), Tang (2000) and Tang et al. (2000).

Two potential threats are traditionally in the spotlight of the AI debate: (1) the provision of management advisory services to audit clients, and (2) the length of tenure of the auditor-client relation.

(1) One of the most controversial issues in the AI debate is the provision of management advisory services to audit clients. Due to the growing economic importance of management advisory services to auditors, the issue is becoming increasingly important to the profession and to the public. The impact is twofold. First, in the mainstream analysis, auditors who provide management advisory services to audit clients become advocates for their clients. Second, they also become more dependent on them. This potentially compromises AI. ${ }^{9}$ Most previous studies have examined the impact of the provision of management advisory services on perceived AI. The results are inconclusive. ${ }^{10}$ Research overviews on the impact of the provision of management advisory services on AI include Wines 
(1994), Acemoglu and Gietzmann (1997), Craswell (1997), Matsumura et al. (1997), Lennox (1998) and Vanstraelen (2000).

(2) Length of tenure of the auditor-client relation is seen as a potential threat to $\mathrm{Al}$ because "complacency, lack of innovation, less rigorous auditing procedures, and a learned confidence in the client may arise after a long association with a client" (Shockley, 1981, p.789). "Here as well, the focus of previous research has mainly been on the impact of length of tenure on the perceived AI. Again, sound evidence indicating that length of tenure actually compromises AI is feeble. Research overviews on the impact of the length of tenure on AI are provided by Arrunada and Paz-Ares (1997), Summer (1998) and Vanstraelen (2000).

In the Netherlands, three potential threats to AI have been investigated: (1) the impact of the provision of management advisory services to audit clients, (2) the impact of the client-fee relation and (3) length of tenure of the auditor-client relation.

(1) The Limperg Institute (1987) studied the perceptions regarding AI of members of the board of supervisors, managing directors of small and mediumsized companies, managing directors of not-for-profit organisations, bankers, shareholders and members of works councils. Of the respondents $59 \%$ indicated that they consider auditors sufficiently independent from their clients. Members of supervisory boards appeared to be most positive on this $(78 \%$ consider auditors sufficiently independent), whereas members of works councils appeared to be most sceptical (40\% consider auditors sufficiently independent). Schilder (1994c) conducted a series of semi-structured interviews with executive managers of multinationals and the Big Six audit firms, politicians and representatives of employers and employees, to investigate perceptions on controversial issues in the Al debate. Most interviewees rejected a ban on the provision of management advisory services to audit clients above $25 \%$ of the audit fee. Trade union leaders more strongly supported the ban than did other interviewees.

(2) The Limperg Institute (1987) also investigated the perceptions of users on the impact of the client-fee relation on AI. In a market-based economy, the audit fee is typically paid by the client. The public may perceive this as a threat to AI. The Dutch auditing profession took steps to mitigate this. For instance, the NIVRA Code of Conduct (NIVRA, 1995) explicitly prohibits auditors from depending too strongly on the audit fees of a limited number of clients for a long time. ${ }^{12}$ The Limperg Institute found that $35 \%$ of the respondents believe that the audit fee should not be paid by the client, running from $15 \%$ of the members of supervisory boards to $52 \%$ of the members of works councils.

(3) Schilder (1994c) also investigated the impact of length of tenure of the 
auditor-client relation on the probability that $\mathrm{Al}$ is compromised. A frequently suggested way to improve AI is a mandatory rotation of the auditor after a fixed number of years. The idea is that if auditors know that they will soon be replaced, they are less likely to be concerned about the attitudes of the company's management. Therefore Schilder (1994c) asked the interviewees for their opinion on a mandatory auditor rotation. They supported a mandatory rotation of the audit partner, but did not see the need for a mandatory rotation of the audit firm. Trade union leaders appeared to be more strongly in support of a mandatory rotation of audit firms than were other interviewees.

The studies performed by the Limperg Institute (1987) and Schilder (1994c) found that employee representatives have different perceptions of AI and of the threats to it than others. This observation justifies further research, and therefore trade union bargainers are under study here. Based on previous work, three potential threats to AI will be investigated in this chapter: (1) the provision of management advisory services to audit clients, (2) the client-fee-relation, and (3) the length of tenure as an auditor.

\subsection{Development of the hypotheses}

\subsubsection{The dependent variable: The AIG}

The reason for investigating the AIG instead of the perceived level of AI directly, is that the level of perceived $\mathrm{AI}$ is a not a potential threat to the auditing profession, but the extent to which the public perceives AI to be substandard is.

The AIG of trade union bargainer i is defined as the discrepancy between his expectations of $\mathrm{AI}$ and his perceptions of actual AI. So:

$A / G_{i}$

$$
\text { Expected } A I_{i} \text { - Perceived } A I_{i}
$$

We consider expectations of $\mathrm{AI}$ as the individual standard of $\mathrm{AI}$ at which the perceived AI will be benchmarked. Therefore, the AIG can be regarded as an indication of the level of disappointment. So, the AIG of trade union bargainer i can take three forms:

1. $A I G_{i}<0$ : perceived actual $A l$ of bargainer $i$ is above the standard of bargainer $i$

2. $A I G_{i}=0$ : perceived actual $A l$ of bargainer $i$ is at standard of bargainer $i$

3. $A I G_{i}>0$ : perceived actual $A l$ of bargainer $i$ is below the standard of bargainer $i$

The AIG can be presented as follows. 
Figure 7.1: The AIG of trade union bargainer $i$.

\begin{tabular}{|c|c|c|}
\hline $\begin{array}{l}\text { AIG } \mathrm{G}_{i}<0 \\
\left(\text { expected } \mathrm{Al}_{i}<\right. \\
\left.\text { perceived } \mathrm{Al}_{4}\right)\end{array}$ & $\begin{array}{l}\mathrm{A} I \mathrm{G}=0 \\
\left(\text { expected } \mathrm{Al} \mathrm{l}_{1}=\right. \\
\left.\text { perceived } \mathrm{Al} \mathrm{l}_{i}\right)\end{array}$ & $\begin{array}{l}\text { AIG }>0 \\
\left(\text { expected } \mathrm{Al}_{i}>\right. \\
\left.\text { perceived } \mathrm{Al}_{i}\right)\end{array}$ \\
\hline $\begin{array}{l}\text { Perceived actual } \\
\text { Al is above standard }\end{array}$ & $\begin{array}{l}\text { Perceived actual } \\
\text { Al is at standard }\end{array}$ & $\begin{array}{l}\text { Perceived actual } \\
\mathrm{Al} \text { is below standard }\end{array}$ \\
\hline
\end{tabular}

We will test the explanatory power of seven variables. As in the previous chapters the focus is on bargaining level as the main explanatory variable. The variation 0 the AIG may also be determined by other variables. Therefore, the impact of si control variables on the AIG will be studied as well. The six control variables are (1) the tolerance for providing management advisory services to audit clients, (2 the tolerance for the client-fee relation, (3) the support for a mandatory auditc rotation, (4) trade union affiliation, (5) level of education of the trade unio bargainer, and (6) length of tenure as a trade union bargainer.

\subsubsection{Hypothesis 1: the impact of bargaining level}

The dual collective wage bargaining system of the Netherlands is introduced in Chapter 1, summarised in Chapter 4 and further explained in Appendix B at the end of this dissertation. ${ }^{13}$ The role of accounting information, including corporate annual reports, potentially differs in CL-bargaining and IL-bargaining. Companyspecific information seems more important in CL-bargaining than in IL-bargaining. As a result, CL-bargainers probably use audited information and meet auditors more often than do IL-bargainers. If CL-bargainers have positive experiences with auditors and auditor's reports, CL-bargainers probably have a lower AIG on average. Experiences might also be negative, causing a reverse effect. Since little is known about the actual experiences, we hypothesise that:

H1 The AIG is related to bargaining level (LEVEL).

\subsubsection{Hypothesis 2: the tolerance for providing management advisory services to audit clients}

Above it was argued that in the eyes of the public, the provision of MAS to audit clients potentially jeopardises Al. This was also noticed in trade union circles. As FNV chairman Stekelenburg said, on the relation between the provision of management advisory services and $\mathrm{AI}^{1 / 4}$ 
"To be an independent expert is always difficult. But because of the authority of the auditor's report we have to prevent this authority from being compromised by the mixing of audit and advisory services. A boundary of $25 \%$ of the audit fee seems acceptable".

We hypothesise that:

H2 The AIG is negatively related to the tolerance for providing management advisory services to audit clients (TOLMAS).

\subsubsection{Hypothesis 3: the tolerance of the client-fee relationship}

It was explained above that in a market-based economy, the audit fee is typically paid by the client. This may be seen as a threat to AI. Indeed, the CNV regards the client-fee relation a potential threat to AI. In 1989, CNV chairman Westerlaken said: ${ }^{15}$

"Changes in the financial reporting legislation are desirable for several reasons: (...) it is the client who pays the audit fee. The client is the company and this makes the auditor dependent on the client."

In 1991, Moizer (1991, p.44) wrote:

"A governmental body [could] be set up (...) This body would be responsible for the appointment of auditors and for determining the size of the remuneration. The audit fee could also be paid by the governmental body, out of a system of levies on companies".

Arens and Loebecke (2000, p.90) also flag the fee problem, and suggest a similar solution:

"Can the auditor be truly independent in fact and appearance if payment of the audit fee is dependent upon the management of the audited entity? There is probably no satisfactory answer to this question (...). The alternative to engagement of the CPA and payment of audit fees by management would probably be the use of either government or quasi-government auditors".

We hypothesise that:

H3 The AIG is negatively related to the tolerance for the client-fee relation (TOLFEE). 


\subsubsection{Hypothesis 4: the length of tenure of the auditor-client relation}

One frequently suggested way to prevent length of tenure from compromising $\mathrm{AI}$ is a mandatory rotation of auditors or audit firms after a fixed number of years. ${ }^{16}$ In 1994, CNV chairman Westerlaken said: ${ }^{17}$

"I support a mandatory rotation of the audit firm after a certain period, with a preference of six years. I also support a mandatory rotation of the partners".

Trade unions, however, are not unanimous on this. FNV chairman Stekelenburg said: ${ }^{18}$

"The rotation of the audit firm is not a real issue. More important is fresh blood. Periodically there must be a change of audit partners. It must not become too static, that is important".

Both chairmen are in favour of a rotation of the auditor after a fixed period of time. The CNV chairman prefers a change of the audit firm, whereas the FNV chairman believes that rotating the audit partner is a sufficient safeguard. We hypothesise that:

H4 The AIG is positively related to the support of a mandatory auditor rotation (SUPROT).

\subsubsection{Hypothesis 5: trade union affiliation}

Section 5.4 positioned the FNV on the left side of the trade union spectrum, the MHP on the right and the CNV in between. Traditionally, the position on the spectrum reflects trade unions' beliefs in the capitalistic system and the desired role of government. In the capitalistic system, the auditor is a free entrepreneur. In 1976 , the FNV $(1976$, p.9) wrote:

"The position of the auditor should be as independent from the client as possible. One can think of an independent public body, that audits corporate information but that is not paid by the client. As a result, the status of the auditor will change".

Given today's market-based organisation of the economy, and the traditional attitude of trade unions in this respect, we expect that among trade union bargainers, the FNV-bargainers have least faith in the independent role of auditors, and therefore we expect that FNV-bargainers have a larger AIG than do CNV and MHP-bargainers. Therefore, we hypothesise that:

H5 The AIG is related to trade union affiliation (TUA). 


\subsubsection{Hypothesis 6: the length of tenure as a trade union bargainer}

Narrowing the AIG is especially important to the auditing profession if there is a positive relation between the magnitude of the AIG and length of tenure as a trade union bargainer. Senior bargainers typically shape trade union policy, and therefore their perceptions potentially have a stronger impact on trade union responses to substandard AI. Since we have no expectation as to the direction of the relation between AIG and length of tenure as a trade union bargainer, we hypothesise that:

H6 The AIG is related to length of tenure as a trade union bargainer (TEN).

\subsubsection{Hypothesis 7: the level of education of the trade union bargainer}

Bollen (1996, p.166) found a significant relation between the level of the user's education and the perceived quality of the auditor's report. Loan officers more highly trained in business administration perceived the quality of auditor's reports to be lower than did other loan officers. We will also focus on level of education to see whether it can explain the variation in AIG. Since we expect little variation in trade union bargainers' training in business administration, we will focus on the relation between the level of education and the AIG. Since we have no $a$ priori expectations of the direction of this relation, we hypothesise that:

H7 The AIG is related to the level of education of trade union bargainers (EDUC).

\subsection{Research method and respondents' characteristics}

\subsubsection{Research method: questionnaire and sample}

This chapter is questionnaire-based. ${ }^{19}$ The data for this chapter and for Chapter 6 were collected simultaneously. The questionnaire had three parts. The first part collected data on the audit expectations gap (for Chapter 6), the second part on AI (for Chapter 7) and the third part on personal characteristics to obtain a profile of the respondents (for Chapters 6 and 7). Subjects received a covering letter, a questionnaire and a prepaid return envelope. ${ }^{20}$

Trade union bargainers in the sample were selected from a list composed for Chapter $5 .{ }^{21}$ For a detailed description of the construction of the sample see Section 5.5.1. of this dissertation.

Before the data can be used, some consideration of possible non-response bias must be made. The non-response bias is tested by comparing the answers of early respondents to those of late respondents (Moser and Kalton, 1986; Oppenheim, 
1992; Hartmann, 1997). The test results can be found in Appendix 7B at the end of this chapter. No significant differences were found between the early and late respondents, suggesting that the views of respondents are not expected to differ significantly from those of non-respondents. Given this, we expect no problem in generalising the results.

Further information on the research method can be found in Section 6.5.1. of this dissertation.

\subsubsection{Respondents' characteristics}

The respondents of this chapter are the same as those in Chapter 6. Table 6.4 ir Section 6.5.2 summarises most of the respondents' characteristics. Furthe characteristics that are relevant for this chapter are presented in Table 7.2. For al three independent variables the difference in mean scores between CL-bargainen: and IL-bargainers is small.

. Eurtber information on the respondents can be found in Section 6.5.2.

Table 7.2: Respondents' characteristics.

\begin{tabular}{|c|c|c|c|c|}
\hline & & \multirow[b]{2}{*}{ ALL } & \multicolumn{2}{|c|}{$\begin{array}{c}\text { Bargaining level } \\
\text { (LEVEL) }\end{array}$} \\
\hline & & & $\mathrm{CL}$ & IL \\
\hline \multirow[t]{2}{*}{$\bar{N}$} & $N$ & 104 & 67 & 32 \\
\hline & $\%$ & 100.0 & 64.4 & 30.8 \\
\hline \multirow{4}{*}{$\begin{array}{l}\text { Tolerance for providing } \\
\text { management advisory } \\
\text { services to audit clients } \\
\text { (TOLMAS) }^{\text {TO }}\end{array}$} & Mean & 2.99 & 3.10 & 2.97 \\
\hline & Std & 1.34 & 1.30 & 1.42 \\
\hline & Min & 1 & 1 & 1 \\
\hline & Max & 5 & 5 & 5 \\
\hline \multirow{4}{*}{$\begin{array}{l}\text { Tolerance for the client-fee } \\
\text { relationship } \\
\text { (TOLFEE) }\end{array}$} & Mean & 3.23 & 3.24 & 3.27 \\
\hline & Std & 1.43 & 1.44 & 1.39 \\
\hline & Min & 1 & 1 & 1 \\
\hline & Max & 5 & 5 & 5 \\
\hline \multirow{4}{*}{$\begin{array}{l}\text { Support for a mandatory } \\
\text { auditor rotation } \\
\text { (SUPROT) }^{\text {a }}\end{array}$} & Mean & 4.23 & 4.21 & 4.14 \\
\hline & Std & 0.95 & 0.94 & 1.01 \\
\hline & Min & 1 & 1 & 2 \\
\hline & Max & 5 & 5 & 5 \\
\hline
\end{tabular}

a=scale 1 to $5: 1=$ low; $5=$ high; CL: corporate-level bargainers; IL: industry-level bargainers; FNV: Federatie Nederlandse Vakbeweging. CNV: Christelijk Nationaal Vakverbond; MHP: Vakcentrale for Middelbaar en Hoger Personeel.

In Table 6.2, the two variables related to bargaining span (number of contracts and number of employees) will not be used in the analysis below, because these variables will strongly correlate with the independent variable of main interest: bargaining level (CL-bargainers versus IL-bargainers). 


\subsubsection{The dependent variable: The AIG}

To measure the AIG, the respondents were asked to indicate the extent to which they support the following proposition:

"Auditors who conduct statutory audits are sufficiently independent from their clients"

The respondents were requested to answer on a five-point scale, coded as -2 if respondents strongly agree with the proposition, coded as -1 if they agree with it, coded as 0 if they are neutral, coded as +1 if they disagree with it, and coded as +2 if they strongly disagree with it. There was an additional opportunity to tick no "opinion/unable to judge". Because of the word "sufficiently" in the proposition, the respondent is asked to benchmark perceived AI to expected AI. Therefore, given Figure 7.1 above, the AIG can be presented as in Figure 7.2.

Figure 7.2: The AIG of trade union bargainer $i$.

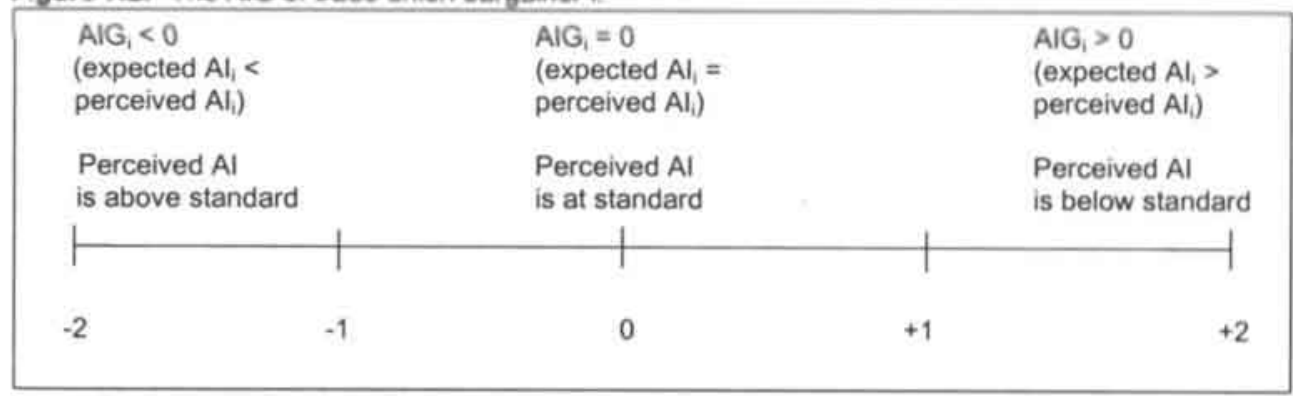

Respondents who provided answer -2 have the largest positive gap between perceived $\mathrm{AI}$ and expected $\mathrm{AI}$, while respondents who provided answer +2 have the largest negative gap.

The answers of the 104 respondents are summarised in Table 7.3.

Table 7.3: The AIG of the respondents $(N=104)$.

\begin{tabular}{clrr}
\hline Answer (Likert-scale) & $\begin{array}{c}\text { "Auditors who conduct statutory audits are } \\
\text { sufficiently independent from the client" }\end{array}$ & $\mathrm{N}$ & $\%$ \\
\hline-2 & strongly agree & 3 & 3.0 \\
-1 & agree & 18 & 18.0 \\
0 & neutral & 42 & 42.0 \\
1 & disagree & 25 & 25.0 \\
2 & strongly disagree & 12 & 12.0 \\
& "no opinion/unable to judge" & 4 & \\
\hline & total & 104 & 100.0 \\
& mean & 0.25 & \\
\hline & median & 0.00 & \\
\hline
\end{tabular}


In Chapter 6 we used three decision rules to conclude whether the performance of auditor duties is perceived as substandard. In this chapter we use the same three decision rules to test whether the AI is substandard: (1) whether the mean score is positive, (2) whether the median score is positive (one-sample Wilcoxon signed ranks test, see Hollander and Wolfe, 1999, p.79), and (3) whether $33.3 \%$ or more of the respondents consider AI substandard. If $33.3 \%$ or more of the respondents consider AI substandard, it is sufficiently widespread to conclude that the AIG exists. Note that the latter two decision rules are also used by Porter (1993), though she was a little less conservative by adopting a $20 \%$-boundary with regard to the third decision rule.

Table 7.3 shows that more respondents perceive AI to be below standard $(37.0 \%$ of the respondents) than above standard ( $21.0 \%$ the respondents) while $42.0 \%$ of the respondents perceive $\mathrm{AI}$ at standard. The mean score is 0.25 . The median score is significantly different from zero ${ }^{22}$ (one-sample Wilcoxon signed ranks test z-score: -2.229 , sign. [2-tailed]: 0.026$)^{23}$, suggesting that on average the AIG is significantly positive. Based on these decision rules we conclude that the perceived AI is below standard.

\subsubsection{Univariate results}

In this section, the impact of the independent variables on AIG is studied in isolation.

The dependent variable is ordinal scaled, as are some of the independent variables. Therefore, non-parametric tests are applied. We use the Mann-Whitney U test for $\mathrm{HI}$ and H5, and the Spearman rank correlation test for the purpose of $\mathrm{H} 2, \mathrm{H} 3, \mathrm{H} 4$, $\mathrm{H} 6$ and $\mathrm{H} 7$.

Table 7.4 presents the descriptive and univariate results. Note that for some hypotheses the number of observations is less than $100(104-4$, see Table 7.3). This is due to missing observations of the independent variables $(\mathrm{H} 4, \mathrm{H} 6$ and $\mathrm{H} 7)$. In $\mathrm{Hl}$, this is because five trade union bargainers indicate that they bargain at corporate and industry-level to the same extent. These five observations were deleted from the sample for the purpose of testing $\mathrm{H} 1$.

HI focuses on the impact of bargaining level on the magnitude of the AIG. To measure the independent variable the respondents were asked to indicate whether they were typically involved in CL-bargaining or IL-bargaining (see Appendix 7A at the end of the chapter for details). The data show that on average, IL-bargainers have a larger AIG than do CL-bargainers $(0.375$ versus 0.206$)$. The difference, however, is not significant. $\mathrm{Hl}$ is not supported. 
H2 expects a negative relation between tolerance for providing management advisory services to audit clients and the magnitude of the AIG. The tolerance for providing management advisory services was measured on a five-point scale with the additional possibility of indicating "no opinion/unable to judge" (see Appendix $7 \mathrm{~A}$ at the end of the chapter for details). A closer look at the independent variable reveals that $40 \%$ of the trade union bargainers do not support the idea that auditors can conduct management advisory services with audit clients without losing their independence as auditors. ${ }^{24}$ The relation is significant, and in the expected direction. The data support $\mathrm{H} 2$.

H3 expects a negative relation between the tolerance for the client-fee relation and the magnitude of the AIG. The tolerance for the client-fee relation was measured on a five-point scale with the additional possibility of indicating "no opinion/unable to judge" (see Appendix 7A at the end of the chapter for details). Of the respondents, $52 \%$ (strongly) agreed with the proposition that auditors can be independent only if they are not paid by the audit client. The relation between the tolerance for the client-fee relation and the magnitude of the AIG is significant, and in the expected direction. $\mathrm{H} 3$ is supported.

$\mathrm{H} 4$ expects a positive relation between the support for a mandatory auditor rotation and the magnitude of the AIG. Here as well, the support for a mandatory auditor rotation was measured on a five-point scale (see Appendix 7A at the end of the chapter for details). Slightly over $80 \%$ of the respondents support a mandatory rotation for auditors who conduct statutory audits. ${ }^{25}$ The relation between the support for a mandatory auditor rotation and the magnitude of the AIG is significant, and in the expected direction. The data support $\mathrm{H} 4$.

H5 investigates the relation between trade union affiliation and the magnitude of the AIG. To measure the independent variable, respondents were asked to indicate their current trade union federation affiliation. To decrease the number of categories and to increase the number of observations in the categories, trade union affiliation is treated as a dummy variable, taking the value 1 in the case of an FNVbargainer and the value 0 otherwise. ${ }^{26}$ The mean scores are in line with expectations. FNV-bargainers have a larger gap than do other trade union bargainers $(0.476$ versus 0.086$)$. The difference between the two groups is significant. H5 is supported.

$\mathrm{H} 6$ expects a relation between the length of tenure as a trade union bargainer and the magnitude of the AIG. To measure the independent variable, respondents were asked to indicate how many years they have been working as a trade union bargainer. The data do not support $\mathrm{H} 6$.

$\mathrm{H} 7$ investigates the relation between the level of education and the magnitude of 
the AIG. To measure the independent variable, respondents were asked to indicate their level of education on a 12-point scale (see Appendix 7A at the end of the chapter for details). The relation is positive and significant, suggesting that higher educated trade union bargainers consider AI more substandard than lower educated trade union bargainers. $\mathrm{H} 7$ is supported.

Based on the univariate analysis, it can be concluded that respondents who have a high tolerance for auditors providing management advisory services to audit clients and who have a high tolerance for the client-fee relation have a smaller AIG. Further, bargainers who more strongly support a mandatory rotation of auditors and who are more highly educated have a larger AIG as well. Finally, FNV-bargainers have a larger AIG than do other bargainers.

Table 7.4: The AIG: descriptive and univariate results.

\begin{tabular}{|c|c|c|c|c|c|c|}
\hline & & & AIG & cale -2 & $0+2)$ & \\
\hline Hypothesis & Subgroup & $\mathbf{N}$ & Mean & Std & Median & Univariate results \\
\hline H1: LEVEL & $\mathrm{CL}$ & 63 & 0.206 & 0.953 & 0.000 & MW: $0.884 ;$ \\
\hline & IL & 32 & 0.375 & 1.040 & 0.000 & sign. (2t): $0.377: N=95$ \\
\hline H2: TOLMAS & 1 (low) & 18 & 0.778 & 0.943 & 1.000 & SM: -0.163; \\
\hline & 2 & 22 & 0.136 & 0.834 & 0.000 & sign (1t) 0.049 : \\
\hline & 3 & 17 & 0.412 & 0.795 & 0.000 & $N=100$ \\
\hline & 4 & 29 & -0.138 & 0.990 & 0.000 & \\
\hline & 5 (high) & 14 & 0.357 & 1.216 & 0.000 & \\
\hline H3: TOLFEE & 1 (low) & 18 & 0.444 & 0.922 & 0.000 & SM: -0.215 ; \\
\hline & 2 & 16 & 0.438 & 0.964 & 0.500 & sign. (1t): 0.014 \\
\hline & 3 & 14 & 0.786 & 0.802 & 1.000 & $N=100$ \\
\hline & 4 & 30 & -0.033 & 1.066 & 0.000 & \\
\hline & 5 (high) & 22 & 0.000 & 0.926 & 0.000 & \\
\hline H4: SUPROT & 1 (low) & 1 & -1.000 & - & -1.000 & SM: 0.176; \\
\hline & 2 & 5 & -0.400 & 0.894 & 0.000 & sign. (1t): 0.037 \\
\hline & 3 & 13 & 0.077 & 0.862 & 0.000 & $\mathrm{~N}=96$ \\
\hline & 4 & 29 & 0.207 & 0.861 & 0.000 & \\
\hline & 5 (high) & 48 & 0.396 & 1.106 & 0.000 & \\
\hline H5: TUA & FNV & 42 & 0.476 & 0.804 & 0.000 & MW: $-2.117 ;$ sign. (1t): \\
\hline & Otherwise & 58 & 0.086 & 1.081 & 0.000 & $0.017 ; N=100$ \\
\hline H6: TEN & Low ( $<4$ years) & 19 & 0.421 & 1.121 & 0.000 & SM: -0.127; \\
\hline & Medium ( $4-8$ years) & 37 & 0.378 & 0.893 & 0.000 & sign. (2t): 0.200 ; \\
\hline & High ( $>8$ years) & 43 & 0.070 & 1.009 & 0.000 & $N=99$ \\
\hline H7: EDUC & Low (level 1-8) & 31 & -0.194 & 0.946 & 0.000 & SM: 0.258; \\
\hline & High (level 9-12) & 68 & 0.426 & 0.935 & 0.000 & sign. (2t): $0.009 ; N=99$ \\
\hline
\end{tabular}

MW: Mann-Whitney z-score; SM: Spearman rank correlation coefficient; 1t: 1-tailed; 2t: 2-tailed; sign: significance level.

\subsubsection{Multivariate results}

This section investigates whether the combination of independent variables can explain the variation in the AIG. The main advantage of multivariate analysis over univariate analysis is that the contribution of each independent variable to the 
variation of the dependent variable can be measured, while all other independent variables are controlled.

We use linear regression to investigate the determinants of the Likert scale-based AIG (cf. Schroeder et al. [1986], Pedhazur and Pedhazur [1991], Carcello et al. [1992], Dassen [1995], Hartmann [1997]).

The following model was estimated:

$A / G=\beta_{0}+\beta_{1} L E V E L+\beta_{2}$ TOLMAS $+\beta_{5}$ TOLFEE $+\beta_{4} S U P R O T+\beta_{6}$ TUA $+\beta_{6} T E N+\beta_{7} E D U C+\epsilon$

These variables are defined as follows:

AIG: Auditor independence gap (scale -2 to $+2:-2=$ strongly agree that auditor is sufficiently independent from the client $+2=$ strongly disagree that auditor is sufficiently independent from the client).

LEVEL: $\quad$ Level of bargaining (đummy variable: $1=\mathrm{CL}$-bargaining, $0=\mathrm{IL}$-bargaining)

TOLMAS: Tolerance for providing management advisory services to audit clients (scale 1-5: $1=$ low; $5=$ high).

TOLFEE: Tolerance for the client-fee relation (scale 1-5: $1=10 w ; 5=$ high).

SUPROT: Support for a mandatory auditor rotation (scale 1-5: $1=$ low; $5=$ high).

TUA: $\quad$ Trade union affiliation (dummy variable: $1=\mathrm{FNV}$-bargainer, $0=$ otherwise).

TEN: $\quad$ Length of tenure as a trade union bargainer (years).

EDUC: Level of education of the trade union bargainer (scale 1-12:1 =low; 12 = high).

Multicollinearity may be an obstacle for multivariate analysis. Multicollinearity can be detected by observing the associations between the independent variables. Table 7.5 is composed for this purpose; it is a matrix of correlation of the independent variables. The correlations involving the level of bargaining and trade union affilition are measured by the Cramér coefficient of association (Siegel and Castellan, 1988, p.225). The Cramér coefficient has a maximum value of 1 and equals 0 when the variables are independent. To test for the association between length of tenure as a bargainer and level of education, the Spearman rank correlation test is applied.

Table 7.5 presents the correlations between the independent variables. All correlations are low to modest, suggesting that multicollinearity does not pose a problem here. 
Table 7.5: Correlation matrix of Model 7.1: correlation coefficients.

\begin{tabular}{|c|c|c|c|c|c|c|}
\hline & LEVEL & TOLMAS & TOLFEE & SUPROT & TUA & TEN \\
\hline TOLMAS & $\begin{array}{r}0.133 \\
{[p=0.789]}\end{array}$ & & & & & \\
\hline TOLFEE & $\begin{array}{r}0.174 \\
{[p=0.814]}\end{array}$ & $\begin{array}{r}0.051 \\
{[p=0.612]}\end{array}$ & & & & \\
\hline SUPROT & $\begin{array}{r}0.191 \\
{[p=0.497]}\end{array}$ & $\begin{array}{r}-0.114 \\
{[p=0.260]}\end{array}$ & $\begin{array}{r}-0.164 \\
{[p=0.105]}\end{array}$ & & & \\
\hline$\overline{T U A}$ & $\begin{array}{r}0.126 \\
{[p=0.218]}\end{array}$ & $\begin{array}{r}-0.163 \\
{[p=0.104]}\end{array}$ & $\begin{array}{r}-0.220 \\
{[p=0.280]}\end{array}$ & $\begin{array}{r}-0.056 \\
{[p=0.589]}\end{array}$ & & \\
\hline$\overline{T E N}$ & $\begin{array}{r}0.487 \\
{[p=0.774]}\end{array}$ & $\begin{array}{r}0.017 \\
{[p=0.863]}\end{array}$ & $\begin{array}{r}0.005 \\
{[p=0.958]}\end{array}$ & $\begin{array}{r}0.065 \\
{[p=0.522]}\end{array}$ & $\begin{array}{r}0.197 \\
{[p=0.217]}\end{array}$ & \\
\hline EDUC & $\begin{array}{r}0.274 \\
{[p=0.517]}\end{array}$ & $\begin{array}{r}-0.054 \\
{[p=0.591]}\end{array}$ & $\begin{array}{r}-0.110 \\
{[p=0.275]}\end{array}$ & $\begin{array}{r}-0.028 \\
{[p=0.522]}\end{array}$ & $\begin{array}{r}0.395 \\
{[p=0.205]}\end{array}$ & $\begin{array}{r}-0.191 \\
{[p=0.054]}\end{array}$ \\
\hline
\end{tabular}

Table 7.6 summarises the results for Model 7.1. The level of bargaining and the tolerance for providing management advisory services to audit clients are the only parameters not significantly different from zero for conventional levels of significance. The overall explanatory power (adjusted $\mathrm{R}^{2}$ ) of the model is $24.5 \%$, suggesting that nearly a quarter of the variation of the AIG is explained by the model. The model as a whole is significant $(\mathrm{F}=5.133$, sign. $=0.000)$.

Table 7.6: Multivariate results: Model 7.1.

\begin{tabular}{lcccccc}
\hline Variable & Coefficient & Predicted sign & Value & Standard error & t-value & p-value, 1-tailed \\
\hline Constant & $\beta_{0}$ & $(?)$ & -0.450 & 0.685 & -0.658 & $0.513^{\prime \prime}$ \\
LEVEL & $\beta_{4}$ & $(?)$ & 0.199 & 0.205 & 0.971 & $0.334^{*}$ \\
TOLMAS & $\beta_{2}$ & $(-)$ & -0.077 & 0.071 & -1.088 & 0.140 \\
TOLFEE & $\beta_{3}$ & $(-)$ & -0.120 & 0.069 & -1.741 & 0.043 \\
SUPROT & $\beta_{4}$ & $(+)$ & 0.208 & 0.100 & 2.084 & 0.020 \\
TUA & $\beta_{5}$ & $(+)$ & 0.476 & 0.209 & 2.278 & 0.013 \\
TEN & $\beta_{6}$ & $(?)$ & -0.046 & 0.015 & -3.147 & $0.002^{\prime \prime}$ \\
EDUC & $\beta_{7}$ & $(?)$ & 0.077 & 0.036 & 2.118 & $0.037^{*}$ \\
\hline
\end{tabular}

$\bar{N}=90 ; \#=2$-tailed; 7 df; $F$-value $=5.133 ;$ sign. 0.000; adj. R2:0.245.

\subsection{Summary and overall conclusions}

This chapter addressed the question: What are trade union bargainers' perceptions of auditor independence and what explains the variation in these perceptions? The research approach of Chapter 6 was followed. The results are based on the views of 104 trade union bargainers, of whom 100 provided information on the nature of the AIG.

The analysis of the AIG reveals that $37.0 \%$ of the respondents perceive AI below standard, while $21.0 \%$ the respondents perceive AI to be above standard. The remaining $42.0 \%$ perceive $\mathrm{AI}$ at standard. We used three decision rules to conclude 
whether the AIG is positive and significantly different from $0:$ : (1) whether the mean AIG is positive, (2) whether the median AIG is positive (one-sample Wilcoxon signed ranks test), and (3) the percentage of respondents who indicated to have a positive AIG (33.3\% or more). Based on all three decision rules we conclude that the AIG is positive and significant, suggesting that $\mathrm{AI}$ is perceived as below standard. Note that Porter (1993) used a $20 \%$-boundary to conclude whether a gap exists instead of the $33.3 \%$ boundary as we did. However, if we use Porter's decision rule, our conclusions would not change.

This chapter tests a series of hypotheses on the variation of the AIG. The variable of main interest is bargaining level. This variable has no power in explaining the variation of the AIG, either in the univariate analysis or in the multivariate analysis. Of the six control variables, tolerance for the client-fee relation, support for a mandatory rotation, trade union affiliation and the level of education of trade union bargainers are significant in explaining the variation in the AIG, both in the univariate and in the multivariate analysis. Tolerance for the provision of management advisory services to audit clients is significant only in the univariate analysis. The impact of length of tenure as a trade union bargainer is only significant in the multivariate analysis.

The support of the hypotheses is summarised in Table 7.7.

Table 7.7: Summary of results to hypotheses.

\begin{tabular}{|c|c|c|c|}
\hline \multicolumn{2}{|c|}{ Hypothesis } & \multicolumn{2}{|c|}{ Significance of the independent variables } \\
\hline & & univariate & multivariate \\
\hline H1: & AIG is related to LEVEL & & \\
\hline $\mathrm{H} 2$ : & AIG is negatively related to TOLMAS & $*$ & \\
\hline H3: & AIG is negatively related to TOLFEE & $*$ & $*$ \\
\hline H4: & AIG is positively related to SUPROT & $\cdots$ & $*$ \\
\hline H5: & AIG is related to TUA & $*$ & $\ddot{*}$ \\
\hline H6: & AIG is related to TEN & & $\cdots$ \\
\hline H7: & AIG is related to EDUC & ... & $*$ \\
\hline
\end{tabular}

AIG: auditor independence gap; LEVEL: bargaining level; TOLMAS: the tolerance for providing management advisory services to audit clients; TOLFEE : the tolerance for the client-fee relation; SUPROT: the support of a mandatory auditor rotation; TUA: trade union affiliation; TEN: length of tenure as a bargainer; EDUC: the level of education; ${ }^{\cdots *}$ significant at the $1 \%$-level; ${ }^{*}$ significant at the $5 \%$-level; all results 2 -tailed.

The multivariate model that includes all seven independent variables is significant and it explains $24.5 \%$ of the variation of the AIG.

How do these findings relate to previous research as summarised in Section 7.3.?

The Limperg Instituut (1987) found that $40 \%$ of the members of works councils consider the auditor sufficiently independent from the client. We found that only $21 \%$ of the trade union bargainers consider auditors sufficiently independent from 
the client. Hence, trade union bargainers are less satisfied about AI than members of works councils.

The first threat to AI investigated was the provision of management advisory services to audit clients. The view in the public debate is that management advisory services compromises AI, but empirical support for this is mixed. Our results are not clear either, since we found that the provision of management advisory services is a significant variable, but only in the univariate analysis. Of the respondents, $40 \%$ did not support the idea that auditors can provide management advisory services to audit clients without compromising AI. This confirms the result presented by the Limperg Institute. There as well, $40 \%$ of the respondents did not support this idea.

The second threat to AI investigated was the client-fee relation. The Limperg Institute found that $35 \%$ of all respondents and $52 \%$ of the members of works councils believe that the audit fee should not be paid by the client. Our results confirm the radical position of employee representatives. We found that $52 \%$ of the trade union bargainers believe that the audit fee should not be paid by the client.

The third threat to AI investigated was length of tenure of the auditor-client relation on the probability that $\mathrm{AI}$ is compromised. A frequently suggested way to improve $\mathrm{AI}$ is a mandatory rotation of the auditor after a fixed number of years. Schilder (1994c) found that trade union leaders more strongly support mandatory auditor rotation than do other interviewees. Our findings confirm the extreme position of trade union leaders in this respect, since slightly over $80 \%$ of the trade union bargainers supported a system of mandatory auditor rotation.

Limitations, research opportunities and policy implications following from this chapter will be discussed in Chapter 8 . 


\section{Appendix 7A: Relevant part of the questionnaire}

Table 7.8 summarises the relevant questions of the questionnaire. The introduction of the questionnaire explained that the focus was on the duties of public registered auditors ("registeraccountants werkzaam voor een accountantskantoor"), and the respondents were asked to provide answers with reference to these auditors only.

Table 7.8: Relevant part of the questionnaire.

\begin{tabular}{|c|c|c|}
\hline Variable & Original questions & Transiation of the question \\
\hline $\mathrm{AIG}^{\circ}$ & $\begin{array}{l}\text { Accountants die optreden als } \\
\text { controleur van de jaarrekening zijn } \\
\text { onafhankelijk genoeg van hun } \\
\text { opdrachtgevers. }\end{array}$ & $\begin{array}{l}\text { Auditors who conduct statutory audits are } \\
\text { sufficiently independent from their clients. } \\
\text { [5-point scale: }-2=\text { strongly agree (perceived Al } \\
\text { is above expectations) to }+2=\text { strongly disagree } \\
\text { (perceived } \mathrm{Al} \text { is below expectations) or "no } \\
\text { opinion/unable to judge"] }\end{array}$ \\
\hline LEVEL & $\begin{array}{l}\text { Bij welk type CAO- } \\
\text { onderhandelingen bent u } \\
\text { hoofdzakelijk betrokken? } \\
\text {-op ondernemingsnivo; } \\
\text {-op bedriffstaknivo; } \\
\text {-geen van beide. }\end{array}$ & $\begin{array}{l}\text { What type of bargaining are you mostly involved } \\
\text { with? } \\
\text {-corporate-level bargaining: } \\
\text {-industry-level bargaining: } \\
\text {-none. } \\
\text { [closed question] }\end{array}$ \\
\hline TOLMAS & $\begin{array}{l}\text { Accountants kunnen bij een } \\
\text { opdrachtgever zowel controleren als } \\
\text { adviseren zonder hun } \\
\text { onpartijdigheid als controleur te } \\
\text { verliezen. }\end{array}$ & $\begin{array}{l}\text { Auditors can conduct management advisory } \\
\text { services with audit clients without losing their } \\
\text { independence as auditors. } \\
\text { [5-point scale: } 1=\text { strongly disagree - } 5 \text { = } \\
\text { strongly agree or "no opinion/unable to judge"] }\end{array}$ \\
\hline TOLFEE* & $\begin{array}{l}\text { Accountants kunnen alleen } \\
\text { onafhankelijk zijn als zij niet door } \\
\text { hun opdrachtgever worden betaald. }\end{array}$ & $\begin{array}{l}\text { Auditor can be independent only if they are not } \\
\text { paid by the client. } \\
\text { [5-point scale: } 1=\text { strongly disagree }-5 \text { = strongly } \\
\text { agree or "no opinion/unable to judge"] }\end{array}$ \\
\hline SUPROT & $\begin{array}{l}\text { Ik ben een voorstander van een } \\
\text { verplichte rotatie van controlerende } \\
\text { accountants (na een jaar of zes). }\end{array}$ & $\begin{array}{l}\text { I support a mandatory rotation of auditors who } \\
\text { conduct statutory audits (after about six years). } \\
\text { [5-point scale: } 1=\text { strongly disagree }-5=\text { strongly } \\
\text { agree or "no opinion/unable to judge"] }\end{array}$ \\
\hline TUA & Bij welke vakbondfederatie werkt u? & $\begin{array}{l}\text { With which trade union federation are you } \\
\text { affiliated? [open ended] }\end{array}$ \\
\hline TEN & $\begin{array}{l}\text { Hoeveel jaar ervaring heeft } u \text { als } \\
\text { vakbondsonderhandelaar? }\end{array}$ & $\begin{array}{l}\text { How many years of experience do you have as a } \\
\text { trade union bargainer? } \\
\text { [open ended] }\end{array}$ \\
\hline EDUC & $\begin{array}{l}\text { Wat is uw vooropleiding? (uw hoogst } \\
\text { behaalde examen). }\end{array}$ & $\begin{array}{l}\text { What is your level of education? (your highest } \\
\text { degree). [closed question: } 12 \text { possible answering } \\
\text { categories, covering all levels of education from } 1 \\
=\text { primary school until } 12 \text { = university } \\
\text { degree/business administration] }\end{array}$ \\
\hline
\end{tabular}

The questions are presented in the same order as in the chapter. Note that this is not the original order of questions as presented to the trade union bargainers: " the scores on this question in the analysis in the chapter were calculated as ( 6 minus original score). 


\section{Appendix 7B: Test for non-response bias}

The test for non-response bias was performed by comparing the answers of the firs 25 respondents (median number of days needed to return the questionnaire: 4 ) wit) the last 25 respondents (median number of days needed to return the questionnaire 38). Table 7.9 below depicts the results.

Table 7.9: Mann-Whitney U-test for non-response bias (all results 2-tailed).

\begin{tabular}{|c|c|c|c|c|c|c|c|c|}
\hline \multirow[t]{2}{*}{ Variable } & \multicolumn{3}{|c|}{ Early respondents $(\mathrm{N}=25)$} & \multicolumn{3}{|c|}{ Late respondents $(\mathrm{N}=25)$} & \multirow[t]{2}{*}{ z-score } & \multirow[t]{2}{*}{ p-value } \\
\hline & Mean & Stdev & Median & Mean & Stdev & Median & & \\
\hline Days & 5.240 & 1.877 & 4.000 & 38.120 & 12.908 & 38.000 & -6.101 & 0.000 \\
\hline AIG & 0.200 & 1.155 & 0.000 & 0.120 & 0.833 & 0.000 & -0.383 & 0.701 \\
\hline TOLMAS & 2.920 & 1.525 & 3.000 & 3.200 & 1.323 & 3.000 & -0.728 & 0.467 \\
\hline TOLFEE & 3.260 & 1.422 & 4.000 & 3.040 & 1.620 & 4.000 & -0.299 & 0.765 \\
\hline SUPROT & 4.292 & 1.042 & 5.000 & 4.417 & 0.717 & 5.000 & -0.069 & 0.945 \\
\hline TEN & 9.860 & 7.222 & 8.000 & 7.177 & 4.615 & 6.000 & -0.963 & 0.336 \\
\hline EDUC & 7.917 & 2.701 & 9.000 & 7.560 & 2.987 & 9.000 & -0.399 & 0.690 \\
\hline
\end{tabular}

For questions and response scales see Appendix 7A, Table 7.8. 


\section{Notes}

1. The author wishes to thank Laury Bollen and Gerard Mertens for comments on an earlier version of this chapter.

2. Several definitions of AI exist in the literature, DeAngelo (1981, p.116) defined the level of independence as "the conditional probability that given a breach has been discovered, the auditor will report the breach." Magee and Tseng (1990, p.322) described a lack of independence as "an auditor's decision that is not consistent with his or her belief about a reporting policy". Lee and Gu (1998, p.534) defined Al as "the absence of collusion between the auditor and manager of the firm".

3. The Dutch auditing profession has been concemed with $\mathrm{AI}$ from the beginning of this century on. See also De Vries (1985, pp.63-64).

4. NIVRA Code of Conduct (Gedrags- en Beroepsregels Registeraccountants), 1994, Article 24, (NIVRA, 1995).

5. For overviews see Schilder (1994c) and Summer (1998).

6. See e.g. Klaassen and Schreuder (1980, pp.29-30), Vergoossen (1993, p.67) and Bollen (1995, p.156).

7. See Summer (1998, p.331) for a similar kind of analysis.

8. See for instance Shockley (1981), Hillisson and Kennelly (1988), Pany and Reckers (1984, 1988a and 1988b), Dopuch and King (1991), Berg (1991), Parkash and Venable (1993), Schilder (1994c) and Dassen (1995).

9. Shockley (1981, p.789), for instance, also presents an argument why the provision of management advisory services to audit clients may increase AI. Management advisory services make the auditor unique to the client, which makes it easier for the auditor to maintain an independent attitude. However, generally it is argued that auditors who provide management advisory services to audit clients face an independence perception problem (see e.g. Craswell, 1999, p.31).

10. For instance, Shockley (1981), Pany and Reckers (1984), Knapp (1985) and Wines (1994) found evidence of a negative relation between the provision of management advisory services to audit clients and (perceived) AI, while McKinley et al. (1985) and Pany and Reckers (1988b) found no effect. Craswell (1999) focused on AI instead of perceived AI in investigating the relation between audit opinion and management advisory services activity. He found no evidence that the auditors' decision to issue a qualified audit opinion to an audit client was affected by the management advisory services provided to that client.

11. Arrunada and Paz-Ares (1997) and Summer (1998) present a different view. They argue that mandatory auditor rotation potentially lowers AI because this "creates additional switching costs, making reputation less valuable and therefore possibly 
compromising AI" (Summer, 1998, p.331). This, however, is not supported empirically.

12. See NIVRA Code of Conduct (Gedrags- en Beroepsregels Registeraccountants), 1994, Article 24, Section 3 (NIVRA, 1995).

13. The main point is that in some companies, trade unions bargain directly with executive management (corporate-level bargaining or CL-bargaining) and in other companies trade unions bargain with representatives of companies within the industry (industrylevel bargaining or IL-bargaining).

14. Interview of Schilder (1994a, p.322) with Stekelenburg. Original text in Dutch.

15. Westerlaken (1989, p.224). Original text in Dutch.

16. A rotation of audit partners is mandatory in Ireland and the United Kingdom. In Italy a rotation of audit firms is mandatory for listed firms (Buijink et al., 1996, pp.76-77).

17. Interview of Schilder (1994b, p.386) with Westerlaken. Original text in Dutch.

18. See Schilder (1994a, p.324).

19. The questionnaire is available from the author on request.

20. The questionnaires were sent between December 1994 and May 1995. After three weeks the subjects received a reminder.

21. See Section 4.4 of this dissertation.

22. Note that the median score for the AIG in Table 7.3 is 0.00 . Nonetheless the median score based on the one-sample Wilcoxon signed ranks test is negative and significant from 0 . This is due to the fact that the one-sample Wilcoxon signed ranks test first deletes zero values from the dataset and then redefines $\mathrm{N}$ to the number of nonzero observation (see also Hollander and Wolf, 1999, p.67).

23. Additionally we performed a one-sample t-test to see whether the mean score is significantly different from 0 . The results indicate that the mean score is positive and significant different from 0 for conventional levels of significance (t-score: 2.529; sign. [2-tailed]: 0.013).

24. They either strongly disagreed or disagreed with the proposition (answer 1 or 2).

25. They either strongly agreed or agreed with the proposition (answer 4 or 5).

26. See Siegel and Castellan (1988, p.49). 


\section{Chapter 8 \\ Summary and Discussion}

\subsection{Introduction}

This concluding chapter is organised as follows. Section 8.2 starts with a summary of this dissertation. In that section the key findings are given on the four research questions put forward in Chapter 1. The aim is not to discuss the corresponding results in great detail. Extensive discussions are provided at the end of each of the chapters. After that, Section 8.3 discusses the limitations of this dissertation. Some issues for future research will be suggested in Section 8.4. Finally, Section 8.5 discusses some policy issues.

\subsection{Summary}

This dissertation focuses on the intersection of accounting, auditing and collective wage bargaining and is concerned with the use and usefulness of accounting information, corporate annual reports and auditing to trade union bargainers.

Trade unions are often mentioned as users of accounting information and auditing. However, there is only a limited amount of empirical evidence for this, and none for the Netherlands. To contribute to the literature, this dissertation addresses four research questions. These questions result from a review of the empirical literature in the field which can be found in Chapter 3 of this dissertation. The following four questions were addressed:

(1) What is the role of accounting and auditing in collective bargaining contracts and employee profit sharing plans, and what explains the variation of this role? (Chapter 4)

(2) Do trade union bargainers use corporate annual reports and do they perceive corporate annual reports as important, and if so, what explains the variation in usage and perceived importance? (Chapter 5)

(3) Do trade union bargainers have an audit expectations gap, and if so, what explains the variation in the gap? (Chapter 6)

(4) What are trade union bargainers' perceptions of auditor independence and what 
explains the variation in these perceptions? (Chapter 7)

The first part of this dissertation investigates the potential usefulness of accounting information, corporate annual reports and auditing to trade union bargainers, both from a theoretical perspective (Chapter 2) and from an empirical perspective (Chapter 3). The second part of this dissertation contains four empirical studies dealing with the four research questions above (Chapter 4 to 7 ). The third part summarises and discusses the results (Chapter 8). The fourth part provides background information (Appendix A to D). Though all linked to the central theme, the empirical essays are intended as separate studies. All chapters have an extensive introduction and can be read more or less independently.

Chapter 1 portrayed trade unions as potential users of accounting information, corporate annual reports and auditing, and presented the motivation for this dissertation. This chapter puts forward the research questions and positioned this dissertation in the financial accounting research. This dissertation is embedded in the Dutch collective wage bargaining setting. This dissertation studies the impact of the dual bargaining structure (corporate- and industry-level) and of trade union bargainer variables (trade union affiliation, length of tenure as a trade union bargainer and level of education of the trade union bargainer) on the perceived usefulness of accounting information, corporate annual reports and auditing. Empirical evidence on this will be collected because collective wage bargaining is an important activity in society, and because corporate-level wage bargaining is becoming increasingly important which probably increases the importance of accounting information and auditing in this setting.

Chapter 2 provided a theoretical underpinning to the research questions and it directed the analysis of the empirical data in the subsequent chapters. It reviewed two sets of theoretical approaches about the usefulness of accounting information to trade unions. The first set consisted of a general, contracting cost theory based explanation of trade unions' use of accounting information, while the second set was a collection of theories of collective wage bargaining used in the empirical financial accounting literature that modelled trade unions' use of accounting information. Both lines of theory make it plausible that financial accounting information is of potential relevance to trade unions in collective wage bargaining. It was hypothesised that trade union bargainers potentially use accounting information for two reasons: (1) for the purpose of general orientation, and (2) for making wage claim decisions. An important determinant of the usefulness of accounting information is perceived reliability. Therefore Chapter 2 also discussed the potential relevance of auditing to trade unions. We concluded that auditing is potentially relevant to trade union for two reasons. First, auditing may add reliability to accounting information prepared and 
disclosed by management. Second, auditing may be used for verifying employee profit sharing plans to reduce agency costs. However, our conclusion that accounting information and auditing are relevant in theory does not necessarily imply that trade unions indeed make use of accounting and auditing in the setting of collective wage bargaining. The latter is an empirical issue that is addressed in various forms in the empirical chapters of this dissertation.

Chapter 3 discussed previous empirical work on the interface of accounting, auditing and collective wage bargaining. More specifically, work was discussed on (1) the usefulness of accounting information to trade unions, (2) the impact of accounting information on the process and outcome of collective wage bargaining, (3) the effect of collective wage bargaining on the process of financial accounting, and (4) on the perceptions of trade unions on independent auditors. The evidence is mainly from Anglo-Saxon origin. The most important conclusions are that (1) trade unions indeed make use of accounting information in collective wage bargaining, (2) accounting information does appear to have an impact on the process of collective wage bargaining, though the impact is complicated, (3) the process of collective wage bargaining may have the capacity to influence the financial accounting process itself, though the empirical results in this respect are mixed, and (4) trade union leaders regard auditor independence an essential ethical issue, though the empirical evidence for this is limited. Based on this evaluation, four research opportunities for this dissertation were identified. Chapter 4-7 addressed these opportunities.

Chapter 4 addressed the first research question. It explored and documented the roles and relative importance of accounting information and auditing in non-executive employee contracts negotiated by trade unions. A panel of 1,332 collective wage contracts effective in 1999 and 1992 was investigated. The results showed that the role of accounting and auditing is limited to a small subset of collective bargaining contracts. They only contained accounting information and auditing for the purpose of defining employee profit sharing plans. The role of auditors appeared to be twofold: to audit annual accounts on which the employee bonus is based, and to decide whether reported profits provide room for a bonus. Compared to corporatelevel employee profit sharing plans, industry-level employee profit sharing plans are defined in less detail. Presumably because industry-level employee profit sharing plans are ill-defined, the role of auditors seems more important in industry-level plans. Note that the latter observation is based on a small number of observations, and for this reason we did not perform a statistical test to see whether the difference is significant.

The second research question was considered in Chapter 5. That chapter reported the findings of a study on the use and perceived importance of corporate annual reports 
in collective wage bargaining. For this purpose, a survey of 101 trade union bargainers was conducted. This chapter addressed three issues: (1) the extent to which corporate annual reports are used in periodic collective wage bargaining, (2) the perceived importance of corporate annual reports, and (3) the perceived importance of the income statement. This chapter attempted to explain the variation of the dependent variables by investigating the impact of bargaining level, and that of five control variables: (1) the importance of company specific information in general orientation in collective wage bargaining, (2) the perceived importance of ability to pay as a justifying argument in making wage claim decisions, (3) trade union affiliation, (4) level of education of the trade union bargainer, and (5) length of tenure as a trade union bargainer. Over $80 \%$ of the trade union bargainers indicated to use corporate annual reports in collective wage bargaining. About $65 \%$ of the users of corporate annual reports considered it a (very) important source of information. And almost $60 \%$ of the users of corporate annual reports perceived the income statement as (very) important. Corporate-level bargainers perceived the corporate annual repor significantly more important than industry-level bargainers. The control variables trade union affiliation and level of education had some explanatory power, length of tenure as a trade union bargainer had no power. The only variable that was positively and significantly related to the dependent variables throughout the analysis is the perceived importance of company specific information in the collective wage bargaining. Trade union bargainers who consider company specific information in general orientation in collective wage bargaining more important, more often use corporate annual reports and they perceive corporate annual reports and income statements as more important than other trade union bargainers.

The third research question was addressed in Chapter 6 . Chapter 6 reported the results of a study on the audit expectations gap. In line with previous work, the gap was split in three components: performance gap, standards gap and reasonableness gap. The variation of the dependent variables was explained by investigating the impact of bargaining level, and that of three control variables: (1) trade union affiliation, (2) level of education of the trade union bargainer, and (3) length of tenure as a trade union bargainer. A panel of 104 trade union bargainers was surveyed. The evidence indicated the existence of the first two components of the audit expectations gap. No evidence was found pointing at the existence of the reasonableness gap. The performance of two of the three existing duties investigated was perceived below standard. Both duties are related to the auditor's role as 'corporate watchdog'. Part of the variation in the gaps can be explained by the variation in bargaining level and by the variation in the control variables. However, the relations are only significant in partial analyses.

Finally, Chapter 7 was dedicated to answering the fourth research question. It reported 
the results of an empirical study on trade union bargainers' perceptions on auditor independence. Auditor independence is generally seen as the most important ethical requirement of auditors. Studying the perceptions of the independence of auditors is an alternative approach to mapping the perceived reliability of accounting information, and as such it sheds a light on the usefulness of accounting information and corporate annual reports. The perceptions on auditor independence of a panel of 104 trade union bargainers were analysed. This chapter attempted to explain the variation of the dependent variable by investigating the impact of bargaining level, and that of six control variables: (1) the tolerance for providing management advisory services to audit clients, (2) the tolerance for the client-fee relation, (3) the support for a mandatory auditor rotation, (4) trade union affiliation, (5) level of education of the trade union bargainer, and (6) length of tenure as a trade union bargainer. The analysis revealed that more respondents perceive auditor independence below standard ( $37 \%$ of the respondents) than above standard ( $21 \%$ the respondents) while $42 \%$ of the respondents perceive auditor independence at standard. Based on three decision rules we concluded that auditor independence is substandard. Bargaining level had no power in explaining the variation in the gap between expected and perceived independence. The independent variables that were significant both in the univariate and multivariate analysis were the tolerance for the client-fee relation, the support for a mandatory rotation, trade union affiliation and the level of education of the trade union bargainer.

A set of four appendices concludes this dissertation. Background information is provided on the Dutch financial accounting and auditing requirements (Appendix A) and on the Dutch system of collective wage bargaining (Appendix B). The contents of two collective wage contracts is presented in Appendix C. Appendix D studied the perceptions of trade unions, companies and that of legal authorities, on trade unions' interest that corporate annual reports comply with the law. It analysed two cases brought to the Enterprise Chamber by trade unions. The analysis suggested that trade unions consider themselves interested parties as far as enforcing the legal compliance of corporate annual reports was concerned. In both cases, the company involved rejected trade unions' claim that they were "interested party". The Enterprise Chamber ruled that in these cases trade unions had to be regarded as interested parties as far as legal procedures against corporate annual reports are concerned. These rulings showed that trade unions may demand companies to comply with the financial accounting law. Moreover corporate annual reports are perceived as relevant to trade unions from both trade union and juridical perspective. Indirectly, it provides additional evidence that corporate annual reports are useful to trade unions. 


\subsection{Limitations}

When interpreting the results of this dissertation, the following limitations must b kept in mind.

(1) The data analysed in Chapter 5,6 and 7 are obtained by questionnaires. The us: of questionnaires to gather data has advantages and disadvantages. A main advantag is that the procedure is less sensitive to biasing compared to interviewing subjects. At other advantage is that the perceptions of a substantial number of subjects can be investigated. A theoretical limitation of the use of questionnaires is that respondent may tend to give socially desired answers. To overcome this problem we explicitly guaranteed the anonymity of the respondents. An other potential limitation is that non response bias prevents that the conclusions can be generalised to the population 0 trade union bargainers. This potential limitation does not seem severe for two reasons First, the response rates in Chapter 5, 6 and 7 were relatively high (over $60 \%$ ), anc tests between the perceptions of early and late respondents did not reveal significan differences.

(2) A further possible limitation is that the sample of trade union bargainers does not represent the population of bargainers fairly. The research method that screens newspapers may be biased towards the leading trade union bargainers. This should make one cautious in generalising the results of Chapter 5,6 and 7 to all trade union bargainers. However, we believe that the impact of this potential limitation is low. Although the number of trade union bargainers in the Netherlands is unknown, a substantial part of the population participated in this research.

(3) The focus of this dissertation was only on the usefulness of accounting information, corporate annual reports and auditing in the context of periodic collective wage bargaining. However, this is only one setting where trade union bargainers may use accounting information. Related settings where accounting information may be useful to trade union bargainers, such as mergers, redundancies and company shut downs are not investigated. Therefore, the findings only provide a partial view on the usefulness of accounting information, corporate annual reports and auditing to trade union bargainers.

(4) A limitation of Chapter 6 is that the relative magnitude of the components of the audit expectations gap is not determined. Measuring the relative magnitude of the components is difficult. To do this, one has to make sure that all relevant duties are included in the questionnaire and the single duties must be weighted. We provide a less sophisticated analysis. We limited the analysis to investigating the existence of the audit expectations gap by focusing on ten auditor duties. One possible 
consequence of this is that the expectations gap is underestimated because trade union bargainers may also have expectations gaps with regard to duties not investigated in this dissertation.

(5) A final limitation of Chapter 6 and 7 is that an arbitrary boundary (33.3\% of the respondents) is used to conclude whether an audit expectations gap (Chapter 6) or auditor independence gap (Chapter 7) is sufficiently widespread among trade union bargainers to say that the gap exists for the group as a whole. Obviously, when a different boundary is used, the conclusions with regard to the existence of the audit expectations gap and auditor independence gap may change (see also Section 6.9 and Section 7.7).

\subsection{Suggestions for future research}

This section contains some research proposals resulting from the analysis in the empirical part of this dissertation.

We believe valuable research on the interface of accounting, auditing and industrial relations concerns: (1) the impact of collective wage bargaining on the process of financial accounting, including issues concerning the selection of accounting procedures and the disclosure of accounting information, (2) the impact of accounting information on the process and outcome of collective wage bargaining (length of bargaining, the occurrence of strikes, wage settlements), (3) the role of trade unions in the standard setting process that led to financial accounting legislation and standards, and (4) the differences in the role of accounting and auditing in nonexecutive and executive contracts and profit sharing agreements.

We explain these research opportunities in greater detail.

(1) One line of financial accounting research examines the extent to which managerial accounting decisions are affected by management incentives to minimise the perceived ability to pay wages. Related issues concern the impact of bargaining on the timing of financial accounting disclosures including the disclosure of interim reports and profit warnings, and on the quality of financial projections such as earnings forecasts. An extension of research to this strand of earnings management literature may contribute to the understanding of the forces that drive financial accounting decisions. The Netherlands seem an interesting setting since earnings management incentives seem to differ among companies because of the dual bargaining structure, and the occurrence of employee profit sharing plans. The success of this type of research strongly depends upon the data and the availability of 
sophisticated tools to measure earnings management. One promising approach to measure earnings management in this setting is an analysis on the behaviour of discretionary accruals. Interesting would be to concentrate on a longer period of time. We believe that this type of research can especially be successful if data are used of medium-sized, non-listed companies since these are commonly involved in less explicit and implicit contracts and, as a result, they attract less attention, which offers room for earnings management. Data of smaller companies are available from 1984 on because of accounting regulation changes. Moreover, since a few years data bases are available containing accounting information of Dutch medium sized companies, which allows data-intensive longitudinal analysis.

(2) The study of the impact of companies' disclosure policy on the process and outcome of collective wage bargaining seems meaningful and requires further attention. Such analysis explores the possible impact of companies' disclosure policy on the productivity (length), atmosphere (threat of strikes), and outcome (wage settlements) of collective wage bargaining. At this time, results for the Netherlands are missing. The understanding of the impact of accounting information on collective wage bargaining can be extended by studying different settings in the Netherlands, including a not-for-profit environment. It may be helpful in identifying obstacles in financial accounting that hamper effective collective wage bargaining or trade union decision making. Identifying the existence and nature of these obstacles would be the first step towards their elimination.

(3) Another interesting research issue is the position of trade unions in the standard setting process in financial accounting. This research has two interesting lines. The first is the process that led to the Law on the Annual Financial Statements of Companies (Wet op de jaarrekening van ondernemingen, or WJO), implemented in 1971, the first extensive financial accounting regulation in the Netherlands. Prior to the enactment of the WJO, several groups including employers and trade unions debated on its desirability and contents. An opportunity to learn more about the usefulness of accounting information is to study the arguments used in this debate, as is done in Maijoor (1991). In that study however the focus was not on trade unions. The second line of research looks into the position of trade unions in the Council for Annual Reporting (Raad voor de Jaarverslaggeving, or RJ) and in its predecessor the Tripartite Accounting Standards Committee (Tripartite Overleg) with regard to proposed guidelines on accounting procedures and disclosure issues. This analysis may contribute to the understanding of the importance of financial accounting issues to trade unions. Again, the Netherlands provide an interesting setting, because for decades, trade unions have an official position in the standard setting bodies.

(4) A final research opportunity is to investigate within companies the links between 
the definition of non-executive and executive employee profit sharing plans. This research may provide new evidence on non-executive and executive goal alignment and on the role of accounting and auditing in this respect. Approaches to this research opportunity include interviewing parties involved in collective wage bargaining, observing actual negotiations and conducting content analysis to compare executive and non-executive profit sharing plans. This research may contribute to the further understanding of the contracting process.

\section{5}

Policy implications

Although it is difficult to give policy advise, some implications for the public policy, executive management, trade unions, and the accounting profession will be suggested. All implications result from three conclusions drawn in the empirical part of this dissertation:

(1) Trade union bargainers use corporate annual reports but they perceive the corporate annual report and the income statement of relatively low importance compared to other professional users.

(2) An audit expectations gap exists and it is composed of a performance gap and a standards gap. Evidence indicating the existence of the reasonableness gap was not found.

(3) Over one third of the respondents consider auditor independence below standard, and they identify a number of treats to auditor independence.

(1) An explanation for the first observation is that trade unions' need for accounting information is not limited to that typically disclosed in corporate annual reports. This observation may trigger the debate on the desirability of extending financial accounting regulation to increase the usefulness of corporate annual reports. Also other user groups, like members of works council and individual employees may benefit from this. Employers' associations and the audit profession should consider to play a role in this debate. There may also be a role for standard setting organisations like the RJ. The disclosure of accounting information, including corporate annual reports, is subject to legal requirements. When evaluating the legislation in this respect, politicians may consider the interests of trade unions and the employees they represent.

(2) The second observation especially requires attention from the audit profession. The large subset of respondents who consider the performance of existing duties (informing the management/board of supervisors on internal organisation deficiencies and reporting going concern problems to outsiders) substandard is a potential issue for discussion within the audit profession. The audit profession may consider ways 
to improve the perceptions of trade union bargainers on these duties. One way to accomplish this is by adapting auditing standards (Richtlijnen voor de Accountantscontrole). Since both duties are related to the "corporate watchdog" role of the auditor, especially attention should be paid to the need for sharpening existing auditing standards in this respect. However, also the possibility of issuing new standards in this respect should not be ignored. The existence of a standards gap increases the need for discussing the scope of auditor duties. Issues to discuss include the audit of interim accounts, the need for discussing the company's financial position with the works council, to need for reviewing the outcome of the employee profit sharing plan, and the possibility to inform works councils on internal organisation deficiencies. The audit profession should join this discussion. Although evidence indicating a reasonableness gap for the group as a whole was not found, looking at the individual level still up to almost one third of the respondents had unreasonable expectations of auditors. One way for the audit profession to narrow this gap is to educate trade union bargainers on the limits of auditors' expertise and on the scope of audits. Finally, also the work of auditors is subject to legal requirements. Politicians could consider to interfere when the audit profession and trade unions together fail to come with solutions to narrow the audit expectations gap.

(3) The third observation basically has the same policy implications as the second. The perceived auditor independence of over one third of the respondents is below expectation. To bring trade union bargainers' perceptions of auditor independence in line with expectations, the audit profession may consider to introduce safeguards that prevent that auditor independence may be jeopardised. First, the fact that the audit fee is paid by the client is seen as a threat to auditor independence. Therefore, safeguards in this respect should be discussed. Second, the length of tenure of the auditor-client relation is seen as a threat as well. The audit profession could address this issue, either by making clear to the public that length of tenure is no threat to independence or the profession must consider the need for implementing a system of mandatory auditor rotation. Again when these discussions fail to provide effective solutions, politicians could consider to take actions because in the market-based economy the public perception of the independence of auditors is vital. 


\section{Appendix A \\ A Note on Financial Accounting and Auditing in the Netherlands}

\section{A.1 Introduction}

The aim of this appendix is fourfold: to briefly discuss the emergence of financial accounting and auditing in the Netherlands (Section A.2), to discuss the financial accounting regulations in the Netherlands (Section A.3), to sketch the contents of corporate annual reports (Section A.4), and to introduce the disclosure rules of corporate annual reports as required by Title 9 (Section A.5). This appendix provides background information for this dissertation. The notes at the end of this appendix refer to additional sources.

\section{A.2 Financial accounting and auditing in the Netherlands}

Before the Industrial Revolution, in the second half of the 19th century, companies in the Netherlands were typically family-owned. During the Industrial Revolution this changed. External parties started to invest in companies. This created a demand of financial accounting information on the financial position and performance of companies. At the end of the 19th century independent audit firms emerged. These firms audited the financial accounting information presented to external parties.' Throughout the 19th century and during the first part of the 20th century, financial accounting and auditing techniques and practices in the Netherlands developed in an almost unregulated environment. However, today financial accounting and auditing in the Netherlands is pretty strongly regulated.

\section{A.3 Financial accounting regulation in the Netherlands}

The first extensive financial accounting regulation in the Netherlands is the Law on the Annual Financial Statement of Companies (Wet op de jaarrekening van ondernemingen, or WJO) which came into effect on May 1st $1971{ }^{2}$ In the 1990 s the relevant legislation is contained in Title 9, Book 2 of the Dutch Civil Code and two separate decrees (the Asset Valuation Decree and the Annual Accounts Format Decree). Title 9 contains rules on the valuation of assets, and on the formats and 
publication of annual accounts. Title 9 is based largely on the Fourth (Company Law) Directive (on the harmonisation of financial statements) and Seventh (Company Law) Directive (on consolidated financial statements) of the European Union. Title 9 applies to four types of legal entities: public limited liability companies (naamloze vennootschappen, or NVs) and private companies limited by shares (besloten vennootschappen, or BVs) as well as mutual insurance companies (onderlinge waarborgmaatschappijen) and cooperatives (coöperaties).

Table Al provides a summary of Title 9.

Table A1: Summary of Titte 9, based on Moret Ernst and Young (1994).

\begin{tabular}{|c|c|c|}
\hline Part & Article & Subject \\
\hline 1 & 360 & General provision \\
\hline 2 & $361-363$ & General provision regarding the annual accounts \\
\hline \multirow[t]{3}{*}{3} & 364 & Regulations governing the balance sheet and notes: basic layout \\
\hline & $365-372$ & Regulations governing the balance sheet and notes: assets \\
\hline & $373-376$ & Regulations governing the balance sheet and notes: liabilities \\
\hline 4 & 377 & Regulations governing the income statement and notes \\
\hline 5 & $378-383$ & Specific regulations governing the notes \\
\hline 6 & $384-390$ & Regulations on the valuation principles and method for determining income \\
\hline 7 & 391 & Directors' report \\
\hline 8 & 392 & Other information \\
\hline 9 & 393 & Statutory audit \\
\hline 10 & 394-395 & Filing and publication \\
\hline 11 & $396-398$ & Exemptions owing to the legal entity's size of operations \\
\hline 12 & $399-404$ & Provisions related to specific activities \\
\hline 13 & $405-414$ & Consolidated annual accounts \\
\hline 14 & $415-426$ & Financial accounting requirements of banks \\
\hline 15 & $427-446$ & Financial accounting requirements of insurance companies \\
\hline
\end{tabular}

Further accounting principles are set out by The Council for Annual Reporting (Raad voor de Jaarverslaggeving, or $\mathrm{RJ}$ ). The $\mathrm{RJ}$ is composed of representatives of the preparers of corporate annual reports, users and auditors. Following the guidelines of the $\mathrm{RJ}$ is not mandatory for companies.

\section{A.4 The corporate annual report and the requirements of Title 9}

Corporate annual reports that come within the scope of Title 9 consists of three parts: (1) the directors' report, (2) the annual accounts, and (3) other information.

(1) The directors' report must provide a true and fair view of the performance and financial position of the company (Article 391). Information on research and development and the expected performance in the next period must be provided. Also information on investments, financing, the number of employees and the circumstances on which future sales and profitability depend must be given. 
(2) According to Title 9 (Article 362.1), the annual accounts must provide:

"in accordance with generally accepted accounting principles, a view enabling $a$ well-founded opinion to be formed on the legal entity's assets, liabilities and results and, insofar as the nature of financial statements permits, of its solvency and liquidity (...)"

The annual accounts consist of the parent company's balance sheet, the parent company's income statement, and the notes to the parent company's balance sheet and income statement. Some companies have to include the consolidated balance sheet and the consolidated income statement and notes to the consolidated statements in the annual accounts as well.

Consolidated annual accounts combine the balance sheets, income statements and cash flow statements of the parent company with those of subsidiaries where the parent company exercises decisive influence. The accounts are turned into an overall set as if the parent and its subsidiaries were a single entity. The goal is to provide a better perspective on total operations than could be obtained by examining the separate reports of each individual company. A legal entity which heads a group must consolidate its accounts (Article 406). The consolidated accounts form part of the notes to the parent company accounts.

(3) Other information concerns a variety of subjects including the auditor's report, profit appropriation and information on events with material financial consequences occurring after the balance sheet date. Statutory audits are compulsory for mediumsized and large NVs, BVs, mutual insurance companies and cooperatives. Small companies and some group related companies are exempted from statutory audits. In first instance, shareholders have the right to appoint the external auditor in the annual meeting (Article 393.2). If shareholders do not exercise their power the supervisory board should appoint the auditor and if not, than executive management should do this. Only auditors who are member of the Royal Netherlands Institute for Registered Accountants (Koninklijk Nederlands Instituut van Registeraccountants or NIVRA), the Netherlands Order of Accountants-Administrative Consultants (Nederlandse Orde van Accountants-Administratieconsulenten or NOVAA) or foreign auditors who are approved by the Minister of Economic Affairs are allowed to conduct statutory audits (Article 393.1). The scope of the statutory audits not only includes the annual accounts but also the other information and the auditor must consider whether the directors' report is consistent with the annual accounts (Article 393.3). Title 9 makes a distinction between the long-form auditor's report and the short-form auditor's report. The short-form auditor's report is part of the other information. The long-form auditor's report is prepared for the purpose of the board of supervisors and executive management. It includes the auditor's report and audit findings with a certain impact (Article 393.4). 
For reason of illustration Table A2 presents the contents of the corporate annual report of Akzo Nobel NV of 1999.

Table A2: The contents of the corporate annual report of Akzo Nobel of 1999 (selection).

\begin{aligned} & \hline Page Subject \\ & \hline 2 Financial highlights \\ & 3 Chairman's statement \\ & 6 Corporate governance \\ & 8 Report of the supervisory board \\ & 12 Milestones in 1999 \\ & 13 Report of the board of management \\ & 13 Strategy \\ & 13 Financial performance \\ & 17 Dividend proposal \\ & 18 People at Akzo Nobel \\ & 18 Research and development \\ & 18 Engineering \\ & 19 Health, safety, and environment \\ & 19 Akzo Nobel in society \\ & 19 Akzo Nobel shareholders \\ & 24 Akzo Nobel's products and markets \\ & 26 Key figures and ratios \\ & 63 Annual accounts \\ & 64 Summary of significant accounting policies \\ & 66 Consolidated statement of income \\ & 67 Consolidated balance sheet \\ & 68 Consolidated statement of cash flows \\ & 69 Notes to the consolidated financial statements \\ & 77 Akzo Nobel NV statement of income (the parent company income statement, HH) \\ & 77 Akzo Nobel NV balance sheet (the parent company balance sheet, HH) \\ & 78 Notes to Akzo Nobel NV statement of income and balance sheet \\ & 84 Other information \\ & 84 Auditor's report \\ & 85 Profit allocation and distributions in accordance with the articles of association \\ & 86 Proposal for profit allocation \\ & 86 Special rights to holders of priority shares \\ & 87 Financial summary \\ & \hline\end{aligned}

\section{A.5 The disclosure of the corporate annual report}

NVs and BVs are required to make the corporate annual report public within five months after the ending of the book year. The annual meeting of shareholders may decide to extent this period to 13 months. The annual meeting of shareholders approves or adopts the annual accounts within the corporate annual report. Next, within eight days the corporate annual report has to be made public by filing it at the Trade Registry of the Chamber de Commerce in the area where the entity is officially registered. There, the corporate annual report is available for inspection.

It is also mandatory to make a Dutch version of the corporate annual report available to the works council for discussion (Works Councils Act, 1971, Article 31a). ${ }^{3}$ 
Notes

1. The first Dutch audit firm, Bureel Van Boekhouding "Confidentia", was founded in 1883 in Rotterdam. For more on the history of the auditing profession in the Netherlands see De Vries (1985) and De Hen et al. (1995).

2. This section partly draws upon the unofficial translation of Title 9 of the Dutch Civil Code as provided by KPMG (1991) and Moret, Emst and Young (1994). For more on the Dutch legislation on annual reporting see Dijksma and Hoogendoorn (1993), Buijink and Eken (1999) and Nobes and Parker (2000). For a detailed description of the history of financial accounting in the Netherlands see Zeff et al. (1992).

3. See also Berentsen and Hoogendoom (1981) and Appendix B at the end of this dissertation. 


\section{Appendix B \\ Introduction to Collective Wage Bargaining in the Netherlands}

\section{B.1 Introduction}

The aim of this appendix is twofold: to introduce the main actors in the Dutch system of industrial relations (Section B.2), and to discuss briefly the main characteristics of the Dutch system of collective wage bargaining (Section B.3). This appendix provides background information for this dissertation. The notes at the end of this appendix refer to additional sources.

\section{B.2 The actors in the Dutch system of industrial relations}

\section{B.2.1 The employee side}

Like in many other European countries the Industrial Revolution in the second half of the 19th century played an important role in the emergence of trade unions.' The predecessors of the first trade unions aimed to protect workers against the risks of the industrialised economy. The first Dutch local trade union was founded in 1861 and the first national trade union in 1866. From the end of the 19th century on, Dutch society was organised according to ideological and religious believes or pillars. ${ }^{2}$ Also Dutch trade unions developed along three of these pillars (Catholic, Protestant and Social Democratic). In 1906 the Socialist Dutch Federation of Trade Unions (Nederlands Verbond van Vakverenigingen or NVV) was founded followed by the Protestant Christian National Trade Union Federation (Christelijk Nationaal Vakverbond or CNV) (1909). The first Catholic trade union federation the Bureau for Roman Catholic Trade Unions (Bureau voor de Rooms-Katholieke Vakorganisaties) was established in 1908 and renamed into Dutch Catholic Trade Union Federation (Nederlands Katholiek Vakverbond or NKV) in 1963. In the 1990s the three largest trade union federations were the Federated Dutch Trade Union Movement (Federatie Nederlandse Vakvereniging, or FNV) (founded in 1982 by a merger of the NVV and NKV), the CNV and the Trade Union for Middle and Higher-level Employees (Vakcentrale voor Middelbaar en Hoger Personeel, or MHP)(founded in 1980). Unlike the FNV and CNV, the MHP focuses on a particular group of employees: the middle and higher-level 
employees. In the 1990s, the FNV was by far the largest and most powerful Dutch trade union federation. Generally the FNV is more radical than the CNV. The CNV is on the right wing of the trade union movement spectrum and it is more consensus oriented than the FNV. Especially as compared to trade unions in other European countries, Dutch trade unions are typically consensus seeking. Consequently, the Netherlands do not have a strong history of industrial disputes, and the working days lost by strikes is rather low. Another feature of Dutch trade unions is their concern for the unemployed and disabled. Via the reallocation of employment trade unions tried to decrease unemployment. This partly explains why trade unions wage claims in the 1990 s were quite moderate.

The trend in membership of Dutch trade unions over a 20 year period is summarised in Table B.1.

Table B.1: The membership of the major trade union federations in the Netherlands.

\begin{tabular}{lrrrccr}
\hline Year & \multicolumn{1}{c}{ FNV } & CNV & MHP & Other & Total & $\%^{2}$ \\
\hline 1980 & 1.078 .000 & 304.000 & 119.000 & 289.000 & 1.790 .000 & 39 \\
1985 & 899.000 & 300.000 & 108.000 & 234.000 & 1.541 .000 & 29 \\
1990 & 975.000 & 301.800 & 125.100 & 250.700 & 1.653 .000 & - \\
1995 & 1.139 .700 & 344.000 & 158.800 & 222.600 & 1.865 .200 & 28 \\
1999 & 1.225 .800 & 361.000 & 218.600 & 123.100 & 1.928 .500 & - \\
\hline
\end{tabular}

a: organisation degree defined as trade union members younger than 65 years old as percentage of the working force; source: CBS (2000); note that the method used to calculate the organisation degree has changed in 1988.

The table shows that in 1995 about $72 \%$, or 6.7 million employees were not unionised. It also shows that trade union federations' membership has fallen from $39 \%$ in 1980 to $28 \%$ of the employees in 1995 . The (socio-economic) impact of trade unions though is larger than is suggested by these data, because collective bargaining contracts (CBCs) also determine the working conditions of nonunionised employees.

Employees are not only represented by trade unions but by works councils too. The aim of the Law on the Works Councils (Wet op de ondernemingsraden 1950, or WOR) was to give advisory power to employees by creating official bodies (works councils) in companies. ${ }^{3}$ The dual goal of these works councils is to promote both the interest of employees and that of the company. The change of the WOR in 1971 made works councils more powerful because management was obliged to consult works council on issues effecting the company and the employees. The change of the WOR in 1979 forced management to discuss a wider range of issues with the works council, including human resource policies.' The WOR does not mention the official task of works councils although some distinct situations are mentioned in which the works councils play a special role. In practice however, the most important qualification of the works council is to give advice about major socio-economic issues related to the company. The WOR also obliges management 
to discuss the corporate annual report with the works council.' Although collective wage bargaining is not one of the task of works councils, in practice the negotiations of works councils with management may also cover issues like wages and overtime payments.

\section{B.2.2 The employers side}

At the turn of the century, as a response to the growing government influence especially in the social security domain, Dutch employers' associations were founded. 'The pillarisation of Dutch society also affected employers' associations. In the 1990s, the Federation of Dutch Industries (Verbond van Nederlandse Ondernemingen or VNO) and Dutch Christian Employers' Federation (Nederlands Christelijk Werkgeversverbond or NCW) were the two most important federations of employers' associations in the Netherlands. Similar to trade unions, these two employers' associations resulted from a string of mergers. The VNO (1945) was the largest and most powerful employers' association which represented many large and medium sized companies. The NCW (1970) was the result of a merger of two associations of Catholic and Protestant employers and was based on Christian principles. Both the VNO and NCW covered a variety of sectors such as manufacturing, transportation, banking etc. Their activities covered issues including general wage policy, regional and industry development, environmental care and education. In 1995 the VNO and NCW merged.

\section{B.2.3 Other actors}

Three other actors are of special importance in the Dutch system of industrial relations: two consulting bodies viz. Foundation of Labour (Stichting van de Arbeid) and the Social Economic Council (Sociaal-Economische Raad or SER) and the government.

The Foundation of Labour is established in 1945 by employers' associations and trade unions and was accepted by the government as an advisory body on socioeconomic issues. Its main goal is to improve Dutch industrial relations. The Foundation of Labour is still an advisory body for Dutch government although it became less important after the foundation of the SER in 1950.

The SER took over some of the official task of the Foundation of Labour.' The SER developed as the main advisory body of the government on socio-economic issues. It has two major functions (1) a supervisory function, and (2) an advisory 
function.' The Dutch government consults the SER on all major socio-economic issues.

The Dutch government itself influences, intervenes and participates in the system of industrial relations in different ways; by developing socio-economic policy, by enacting legislation, by participating in the tripartite discussions (together with trade unions and employers' associations), and in collective wage bargaining in the role as employer.

\section{B.3 The bargaining process}

Annual collective wage bargaining starts with negotiations at national level between the federations of trade unions and employers' associations to reach a Central Agreement (Centraal Akkoord) in the Foundation of Labour.' Then the details are negotiated at industry or at corporate-level. In practice, social partners mostly fail to agree upon a Central Agreement. Then bargaining proceeds, either at industry or at corporate-level. ${ }^{10}$ Most employees are covered by an industry-level contracts." Companies in particular branches and a number of other companies are covered by corporate-level contracts. Although most CBCs are corporate-level contracts, the working conditions of most employees are covered by industry-level (see Table B.2 below). CBCs can be split into two groups, (1) standard CBCs between trade unions and employers that cover the working conditions of a particular group of employees, and (2) ad hoc CBCs between trade unions and employers that contain specific arrangements (like on redundancies or early retirements) of a particular group of employees. On employers side, individual employers and employers' associations may participate in collective wage bargaining. At employee side, only officially recognised trade unions may do so. Whenever a CBC is concluded, parties are obliged to report this to the Ministry of Social Affairs and Employment, were the CBCs are filed. The Minister is entitled to declare a CBC valid for particular group of employers and employees, even though they were not involved in the bargaining process. CBCs cover a wide variety of items such as wages, health issues, medical insurance, training programs etc. ${ }^{12}$

Table B.2: Number of $\mathrm{CBCs}$ in 2000 .

\begin{tabular}{lcc}
\hline Type of contract & Number of CBCs & Number of employees \\
\hline CL-contract & 767 & 784,50 \\
II-contract & 185 & $4,910,00$ \\
Specific contracts & 321 & $6,230,00$ \\
Total & 1,273 & \\
\hline
\end{tabular}

Source: MSZW (2000, Appendix 4): CBCs with expiration after April 15, 1995; Cl-contract: corporate-level contract: IL-contract, industry-level contract. 


\section{Notes}

1. This section draws upon Windmuller (1969). For the history of trade unionism in the Netherlands see Brugmans (1975), Albeda and Dercksen, (1989), Campbell and Windmuller (1992) and Van Voorden et al. (1993).

2. In Dutch called zuilen. For more on the pillarisation of the Dutch society see for instance Ramondt (1981).

3. For an extensive review of works councils in the Netherlands see Windmuller (1969, chapter 10) and Van Haren (1982).

4. The works council consists of representatives chosen by the employees of the company. The number of employees of works councils range from 3 members (companies smaller than 50 employees) to a maximum of 25 employees (companies with more than 15,000 employees).

5. See article $31 \mathrm{a}$ of the Works Council Act (1979). For a discussion of this article see Van Haren (1982, pp.123-124 and p.216).

6. For a review of and a more detailed analyses of the start and development of Dutch employers' associations before World War II see Windmuller et al. (1990, especially chapter 2) and Vos (1982, chapter 4). For an extensive discussion of Dutch employers' associations see Windmuller (1969, chapter 6), Van Voorden (ed., 1981, chapter 4), Van Voorden (1984, pp.202-231) and Reynaerts and Nagelkerke (1986).

7. See also Ramondt (1981, p.402) and International Research Group (1981, p. 142).

8. The representative body of the SER comprises 45 members who are considered to be representatives of "national interests"; 15 represent the trade unions, 15 represent the employers' association and 15 "crown members" are nominated by the government. Furthermore the SER has established a number of committees which deal with specific socio-economic issues.

9. For more information on the process of collective wage bargaining in the Netherlands see Windmuller (1969), Albeda (1971 and 1985) and Ramondt (1981).

10. The rules of the collective wage bargaining process are defined by the Collective Contract Law (1927) and to a lesser extent by the Extension and Nullification of Collective Bargaining Contracts Law (1937).

11. See also Albeda (1971, p.316).

12. See Appendix $\mathrm{C}$ at the end of this dissertation for the contents of two CBCs. 
184

Appendix B 


\section{Appendix C \\ The Contents of Collective Bargaining Contracts: Two examples}

Below two examples of collective bargaining contracts are presented. Table C.1 presents the contents of a corporate-level collective bargaining contract, while in Table C. 2 an example of an industry-level collective bargaining contract is presented.

Table C.1: An example of a corporate-level collective bargaining contract.

\begin{tabular}{llll}
\hline \multicolumn{4}{c}{ CBC of Philips (B) (Nederlandse Phillipsbedriven etc.) (selection of articles) } \\
\hline Art. & Topic & Art. & Topic \\
\hline 6 & Employment & $17 \mathrm{a}$ & Holiday Pay \\
$6 \mathrm{a}$ & Employability & $17 \mathrm{~b}$ & Year bonus \\
7 & Consultation about employment & 18 & Employee bonds \\
8 & Labour conditions & $19 \mathrm{a}$ & Payment in case of disablement \\
$11 \mathrm{~d}$ & $3 \%$ bonus & 21 & Health insurance \\
13 & Holiday & 22 & Pension fund \\
14 & Absence & 24 & Works councils \\
15 & Monthly salary & 26 & Disciplinary sanctions \\
$15 \mathrm{a}$ & Collective Wage Development & 28 & Strikes \\
$16 \mathrm{a}$ & Bonus for shift work & & \\
\hline Art: article; effective: April, 1st, 1998 to March 31, 2000; 46 pages.
\end{tabular}

Table C.2: An example of an industry-level collective bargaining contract.

\begin{tabular}{llll}
\hline \multicolumn{4}{c}{ CBC of Wholesale business in building materials (selection of articles) } \\
\hline Art. & Topic & Art. & Topic \\
\hline 4 & Employment & 23 & Working hours \\
5 & HR policy and the quality of labour & 24 & Reduction of working hours \\
6 & Senior employees & 25 & Overtime work \\
8 & Trade union facilities & 27 & Discharge \\
9 & Education & 30 & Pension \\
10 & Labour market and recruitment policy & 31 & Life insurance payment \\
11 & Part-time work & 35 & Holidays \\
16 & Salary scales & 37 & Leave arrangements \\
18 & Minimum salary of sales representatives & 40 & Day care centre (crèche) \\
22 & Payment schemes & 45 & Disputes \\
\hline
\end{tabular}

Art.: article; effective: April, 1st, 1999 to March 31, 2000; 120 pages. 


\section{Appendix D}

\section{A Note on Trade Unions' Interest in Corporate Annual Reports: The case of the Dutch Enterprise Chamber}

\section{D.1 Introduction}

Modern industrial relations makes one forget sometimes that there has been a capitallabour controversy for a long time. This controversy still exists, however in a less prominent way. This appendix goes back to the 1960 s and 1970 s where the capitallabour controversy was more visible, and it studies the attitudes of politicians, trade unions, companies and legal authorities to trade unions' rights to receive true and fair accounting information. The Dutch institutional framework explicitly provides possibilities of legal review for parties that have an interest in corporate annual reports (CARs). This appendix analyses two cases brought before the Dutch Enterprise Chamber (Ondernemingskamer or OK). In both cases trade unions filed a charge of failure to comply with financial accounting law and demanded restatement of the CAR. This appendix aims to shed light on the views politicians, trade unions, companies and legal authorities have concerning trade unions' interest in CARs, and consequently on whether they may take legal action to force companies to prepare their CARs in accordance with directions to be given by the OK. The analysis offered attempts to increase historical awareness of the accounting-industrial relations interaction, and by doing so it aims to contribute to our understanding of the role of accounting in society today.

Dutch employees are represented in corporate governance by company related works councils and independent trade unions. In the Netherlands, the law treats works councils and trade unions differently with reference to the disclosure of accounting information. The Works Council Law (1971, Article 31a) obliges companies to present their CAR to works councils, but there is no similar legal requirement to provide accounting information to trade unions. Hence, the law explicitly recognises works councils as interested parties concerning CARs, but does not see trade unions in the same position.

This appendix investigates whether politicians, trade unions, companies and legal authorities consider trade unions as parties with a valid interest in CARs. This 
appendix aims to contribute to the existing literature on accounting and industrial relations in three ways:

(1) It examines trade unions' interest in CARs from four different perspectives: that of politicians, trade unions, companies and legal authorities, which is new.

(2) It focuses on two cases brought before the $\mathrm{OK}$, an institution unique in the context of financial accounting.

(3) It studies the usefulness of CARs to trade unions from an industrial relations setting within continental Europe, whereas the focus of most of the previous studies is on the Anglo-Saxon industrial relations setting.

(1) Accounting researchers usually study trade unions' interest in accounting information from the trade union's perspective, focusing on their information needs, their decision processes or their wage claims. In order to achieve a more thorough understanding, this appendix also examines the views of other parties on trade unions' interest in accounting information. The evidence presently available regarding trade unions' reactions if they believe CARs do not comply with the law is limited, as is evidence concerning the reactions of regulators, preparers of CARs and legal authorities on trade unions' interest in CARs. This appendix aims to present some evidence in this regard.

(2) Klaassen (1980) summarised the main characteristics of the OK and provided a discussion of the first few cases filed there.' One case concerned two trade unions versus Homburg, a producer of meat products. This appendix will re-examine the Homburg case in greater detail. A second case, which has not been discussed by Klaassen, will also be studied. This case concerns a cigarette manufacturer. The trade unions' position will be examined by investigating the process prior to the enactment of the law establishing the $\mathrm{OK}$, as well as by studying the two cases mentioned, looking at the position of trade unions, the response of the two companies concerned and the reactions of the $\mathrm{OK}$.

(3) The usefulness of accounting information to trade unions has been the focus of various studies. An overview is presented in Section 3.2.2 of this dissertation. Most of the previous work is based within the framework of Anglo-Saxon industrial relations. So far, little is known about the relevance of CARs to trade unions within continental Europe. This appendix aims to provide evidence on this.

Note that studying legal cases to learn more about the role of accounting information is not new. Clarke and Craig (1991) studied major Australian wage fixation tribunal cases to learn more about the serviceability of historic cost-based accounting reports in determining the (in)capacity to pay money wages. This appendix, however, targets 
a more basic goal: to study perceptions of trade unions' interest in CARs.

\section{D.2 The Enterprise Chamber}

In 1965, the Verdam Commission ${ }^{2}$, which had prepared the draft of the Law on the Annual Financial Statements of Companies (Wet op de jaarrekening van ondernemingen or WJO), considered two options concerning enforcement of the legal compliance of CARs: an administrative and a judicial approach. The Commission recommended adopting the second approach. In 1970, the Dutch parliament approved the WJO, thereby establishing the OK. The law has been effective since 1971. The WJO introduced a detailed set of accounting requirements that had previously been almost absent. In 1976, the WJO became part of the Civil Code as Title 6 of Book 2, Article 306-343. The most essential requirement that CARs had to meet was established in Article 2, WJO:

"The annual accounts provides such information that a sound judgement can be formed on the financial position and results of the enterprise and, to the extent to which annual accounts permit, on its solvency and liquidity".

The WJO provided the opportunity for interested parties and for the Procurator General (comparable to the British Attorney General) to file a complaint regarding the CAR with the OK when they believe the CAR falls short of the law. Then the OK may look into the case and may give directions to the company to restate the CAR concerned.

\section{D.3 Trade unions' interest in CARs: political perspective}

This section will focus on the Parliamentary discussions that occurred prior to the acceptance of WJO, especially with regard to the scope of Article 31. That Article was as follows: ${ }^{4}$

"Each interested party holding the view that the annual accounts of an enterprise do not meet the relevant requirements laid down in this act may take action in law to force the enterprise to prepare its accounts in accordance with directions to be given by order of the court."

The WJO did not identify the parties that have an interest in CARs. The key question in the context of this appendix is whether interested parties referred to in Article 31 include trade unions. Before the WJO was enacted, Dutch Parliament debated extensively on the scope of that Article. During discussions in the First Chamber of 
Parliament, the Minister of Justice stated: ${ }^{5}$

"In this bill we use the term any "interested party", to leave room for the judge to determine who should have this right. I presume the judge will give a wide interpretation. In other laws the term "directly interested party" is applied; however in this draft the word "directly" is omitted (...). A wise judge will say only rarely that a specific group is never an interested party and another group is always an interested party."

The official explanatory comments that appended the WJO interpreted interested party as follows:

"Generally, in order to be regarded as an interested party it is required that one has a direct and a demonstrable interest in the annual accounts. This criterion cannot be laid down in a strict general rule. Shareholders (...) will always be regarded as interested in the complete anmual accounts because in the first instance it is for their benefit that the accounts are prepared, are submitted to them, and assessed or approved by them: they have a direct interest in the financial position and results of the enterprise (...). Other categories, however, are less concerned with the presentation gf the, financial, oosition aved, caswls (...). Thus it depends on the factual situation and particularly on the requirements of the persons involved, whether they are to be regarded as interested parties and it is for this reason that the act does not specify the categories. "

The explanatory comments on Article 31 discuss the status of employees and their organisations as follows:?

"Under certain conditions employees and their organizations may be interested in knowing the enterprise's financial position and results in the form in which the latter are to be presented and published by virtue of the statutory requirements, and thus these categories are interested parties (...). The conditions of the case, however, will determine whether their interest warrants any action."

Hence, the scope of the interested party was defined fairly broadly in the WJO, and it was left to the discretion of the OK to interpret which parties are interested in the CAR on a case by case basis. Or, as the explanatory comments for Article 31, WJO stated:" "(...) jurisprudence will have to develop the concept 'interested party '."

\section{Trade unions as plaintiffs at the $\mathrm{OK}$}

Trade unions have taken two cases to court, demanding restatement of the CARs of 
the companies involved: NVV/KB vs. Homburg (pronouncement date: April 14, 1977) and FNV vs. British American Tobacco (further Batco) (pronouncement date: November 13, 1980). The remainder of this appendix will focus on these two cases.

\section{D.4 Trade unions' interest in CARs: trade union perspective}

\section{NVV/KB vs Homburg}

The plaintiffs in this case were two trade unions operating in the food industry (further referred to as NVV/KB) ${ }^{\circ}$ and the defendant was Homburg, a producer of meat products. NVV/KB were assisted by SOBI, a social pressure group that over time was involved in a number of cases at the OK." The trade unions' complaints concerning Homburg's 1975 CAR were that (1) information in the notes to the consolidated statements was wrong, (2) the valuation of fixed assets in the consolidated balance sheet was wrong and (3) the interest payment on a loan provided by the parent company was actually a dividend payment, and should therefore also be accounted for as such." Homburg employees were entitled to a bonus that was related to the dividend paid by Homburg. Trade unions claimed that because Homburg voluntarily agreed to replace a loan with a low interest rate from the parent company with a loan at a higher rate of interest, earnings and therefore the dividends paid to the parent company were lower and the employee bonus was consequently decreased.

NVV/KB argued that they had an interest in Homburg's CAR, and therefore they wanted to force the company to comply with the financial accounting law, because: ${ }^{12}$

"trade unions have to be able to form a well-founded opinion of the assets, liabilities, earnings, solvency and liquidity of Homburg in order to fulfil their tasks properly".

NVV/KB used four arguments to back up their claim for a direct interest in the CAR. ${ }^{13}$ First of all, if Homburg was to consider a merger or the closure of (a part of) the company, it would be obliged to inform trade unions about the impact this would have on employees, according to the collective wage agreement of the industry. Second, half the members of two supervisory institutions in the meat producing industry were appointed by trade unions. The first institution was involved in the entrance of new companies to the industry and the second was concerned with industry wide wages and labour conditions. Third, according to their bylaws, $\mathrm{NVV} / \mathrm{KB}$ were obliged to serve the interests of their members in the company. Fourth, due to the role and rights of trade unions as described in several acts, $\mathrm{NVV} / \mathrm{KB}$ believed that they could not do without accurate and reliable information 
regarding Homburg's assets, liabilities and earning.

\section{FNV vs Batco}

In this case, the plaintiffs were two FNV unions in the transportation and food industry ${ }^{14}$ (hereafter referred to as FNV) and the defendant was Batco. Batco produced cigarettes at a plant in Amsterdam. The company had a $71.6 \%$ share in BAT Benelux which produced cigarettes at a plant in Brussels. Batco decided to shut down the factory in Amsterdam and to concentrate the production of cigarettes in Brussels to increase efficiency. The FNV filed a complaint against the 1977/1978 CAR of Batco because; (1) the notes accompanying the figures contained inaccurate information, (2) the accounting procedures used to calculate earnings were changed without mentioning this, (3) corporate income taxes were not accounted for properly, and (4) general reserves were not treated as required. The FNV demanded Batco to restate the CAR with reference to these points. The employees of Batco were not entitled to an earnings related bonus.

According to the FNV, Batco had managed its earnings in order to justify its plan to shut down the Amsterdam plant. The FNV felt that the CAR would be essential during the negotiations concerning the shutdown. The union argued that if later, during negotiations, they claimed that the CAR didn't comply with the law, Batco was likely to reason that the CAR had been agreed upon without any appeal from the trade union. The FNV felt that a verdict from the OK would have a greater impact on the proceedings regarding the shutdown than a study concluding that actual earnings were higher than reported.

\section{D.5 Trade unions' interest in CARs: company perspective}

\section{NVV/KB vs Homburg}

Homburg claimed that trade unions were not allowed to file a demand to restate the CAR, because they believed the scope of Article 31 did not include trade unions. Homburg argued that: ${ }^{15}$

"given their goals, [it] may be [that] trade unions have an abstract interest in CARs, but this is not sufficient to file a complaint [at the Enterprise Chamber] since it is clear from previous interpretations of the law and from literature that a party is only interested if it has a "direct" interest in the nullification of the CAR". 
In opposing the rights of trade unions to file a complaint, Homburg argued further that they regarded the works council as the relevant employee representative. According to Homburg: ${ }^{16}$

"in [the] first instance the works councils are the interested parties concerning matters affecting employees. It is not likely that the legislature has given trade unions the right to file a complaint against the CAR without, as is the case here, any consultation with the works council. Anyone who has an abstract interest or serves the interest of certain groups has to turn to the Procurator General at the Court of Justice of Amsterdam, who is entitled to institute a procedure such as the one discussed here (...) for employees in first instance the works council is the party interested in CARs".

\section{FNV vs Batco}

Batco rejected the claim that trade unions were interested parties by using only one argument: the employees of Homburg did not receive a bonus payment related to the $\mathrm{CAR}$ and therefore the trade unions had no interest in the CAR.

\section{D.6 Trade unions' interest in CARs: Enterprise Chamber perspective}

\section{NVV/KB vs Homburg}

The OK considered that (1) the goal of the NVV/KB is to serve the interests of the members, (2) employees of Homburg are among the members of the NVV/KB, (3) trade unions are organisations of employees that have the right to ask for a special investigation as mentioned in Article $346 \mathrm{~b}$, Title $6^{17},(4)$ based on what was written in the collective wage agreement, Homburg has to inform and consult the NVV/KB with respect to important decisions affecting employees, and (5) the employees of Homburg are entitled to a bonus that depends on the dividend paid by Homburg. The OK ruled:"1

"Because of the above mentioned facts and circumstances and considering their mutual relations, trade unions have, (...), a direct personal interest in the underlying $C A R$; therefore they may be regarded as interested parties as in Article 337, Title 6 of Book 2 of the Civil Code [before 1976, Article 31, WJO. $\mathrm{HH}]$." 


\section{FNV vs Batco}

The OK concluded that the FNV is an organisation of employees that, according to its bylaws, serves the interest of its members. If employees of Batco are among the members and if consultation takes place based on the CAR, trade unions have in general an interest that the CAR complies with the law. Moreover, the FNV is an interested party because the information in the CAR is important to study the shutdown of the Amsterdam plant. ${ }^{19}$

If there are differences of opinion on whether CARs fall short of what the law requires, the trade unions may start a legal procedure at the $\mathrm{OK}$.

\section{D.7 Summary and conclusions}

This appendix adopts an alternative approach to study the trade unions' interest in CARs. The focus is on parliamentary discussions and on two cases brought before the OK by trade unions. This appendix investigates not only the views of trade unions, but also the perceptions of politicians, legal authorities and companies on trade unions' interest in CAR. Indirectly this appendix also sheds light on the relevance of accounting information to trade unions. Especially evidence on this from the European continent is limited.

Looking at the discussions prior to the enactment of the WJO, Dutch politicians did not identify trade unions as parties that always and unconditionally have an interest in CARs. However, neither did they reject trade unions as such. In the view of politicians, whether or not they are an interested party depends on the particular conditions of each case. Those conditions were not specified.

Trade unions brought two cases before the $\mathrm{OK}$ where they claimed that the companies involved failed to comply with the financial accounting law (NVV/KB vs. Homburg and FNV vs. Batco). They raised issues with regard to: (1) the disclosure of accounting information including the relation between figures and notes (Homburg and Batco), (2) the valuation of assets and liabilities (Homburg and Batco), (3) the adoption of accounting procedures and the perceived lack of consistency in the procedures (Batco) and the impact of these two factors on reported earnings (Homburg). The trade unions' appeal illustrates that they regard themselves as interested parties.

Both Homburg and Batco denied that the trade unions were parties with an interest 
in CARs. Homburg argued that the works council was the interested party on issues regarding employees' interests. Batco denied the interest of the FNV because there was no employee bonus plan based on the CAR.

In both cases the OK declared that the trade unions were parties interested in CARs because: (1) the trade unions had employees among their members (Homburg and Batco), (2) due to several arrangements, the trade unions had to be informed and consulted on important decisions (Homburg and Batco), and (3) the employees were entitled to a bonus based on the CAR (Homburg).

However, in both cases the OK concluded that the CAR did satisfy the legal requirement, and the OK rejected the trade unions' demand to force the companies to restate the CAR. In both cases the trade unions were ordered to pay the costs of the legal procedures.

After these two cases, the trade unions did not file new charges of failure to comply with the financial accounting law with the OK. In 1993, Zeff (p.157) concluded:

"shareholders and employees have apparently been reluctant to bring cases, owing to the cost and the amount of time (usually two to four years) until a decision is announced".

Another possible explanation why trade unions did not continue to bring cases before the $\mathrm{OK}$ is the lack of success the trade unions had in the first two cases in forcing the companies to restate their CAR. However, the trade unions were successful in one respect. In both cases the $\mathrm{OK}$ ruled that the trade unions were parties interested in CARs, or, in other words, the OK considered it important for the trade unions to know the financial position and results of a particular company. And if CARs fall short of what the law requires, trade unions have the right to bring proceedings against the company. For this reason, the rulings implied a small shift in power between companies and trade unions in the context of Dutch collective bargaining. 


\section{Notes}

1. For more on the OK see Klaassen (1980), Joosten (1989), Zeff et al. (1992), Dijksma and Hoogendoom (1993), and Nobes and Parker (2000).

2. For more on the Verdam Commission see Zeff et al. (1992, pp.148-159).

3. Translation of NIVRA (1972).

4. Translation of NIVRA (1972).

5. First Chamber of Parliament, Proceedings (September 8, 1970, p. 1094). Translated into English. See also Sanders and Burgert (1977, p.395).

6. First Chamber of Parliament, Proceedings (September 8, 1970, p. 1094). Translation of NIVRA (1972, p. 97).

7. Translation of NIVRA (1972, p. 99).

8. Translation of NIVRA (1972, p. 99).

9. The plaintiffs were Voedingsbond NVV and the Katholieke Bond van Personeel in Agrarische, Voedings- en Genotmiddelen, Tabaksverwerkende, Horeca en Aanverwante Bedrijuen.

10. For more on SOBI see Zeff et al. (1992, pp.191-192) and Zeff (1993, p.158).

11. A five-year loan was granted by the parent company in 1972 at an interest rate of $9.5 \%$. In 1975 this loan was voluntarily repaid and a new loan was agreed upon at an interest rate of $11.5 \%$, although the market rate of interest at that moment was about $9 \%$.

12. See Nederlandse Jurisprudentie (1978, Case 442, p.1511). Translated into English.

13. See Nederlandse Jurisprudentie (1978, Case 442, p.1511). Translated into English.

14. These two trade unions were the Vervoersbond FNV and Voedingsbond FNV.

15. See Nederlandse Jurisprudentie (1978, Case 442, p.1511). Translated into English.

16. See Nederlandse Jurisprudentie (1978, Case 442, p.1511). Translated into English.

17. This article deals with the right of inquiry or investigation (Het recht van enquete). It explicitly mentions trade unions as parties that are allowed to start an inquiry on certain company policies or decisions. 
18. Translated into English.

19. See Nederlandse Jurisprudentie (1981, Case 259, p.858). 


\section{References}

AAA, (1977), Statement on Accounting Theory and Theory Acceptance, Committee on Concepts and Standards for External Financial Reports, American Accounting Association, Sarasota, Florida.

Abowd, J.M., J.S. Tracy, (1989), Market Structure, Strike Activity and Union Wage Settlements, Industrial Relations, Vol.28, pp.227-250.

ACCA, (1992), Eliminating the Expectations Gap, Association of Chartered Certified Accountants, London.

Acemoglu, D., M.B. Gietzmann, (1997), Auditor Independence, Incomplete Contracts and the Role of Legal Liability, The European Accounting Review, Vol.6, pp.355-375.

AICPA, (1978), Report. Conclusions and Recommendations of the Commission on Auditors' Responsibilities (The Cohen Commission), American Institute of Certified Public Accountants, New York.

AICPA, (1986), Restructuring Professional Standards to Achieve Professional Excellence in a Changing Environment, Report of the Special Committee on Standards of Professional Conduct for Certified Public Accountants, American Institute of Certified Public Accountants, New York.

Albeda, W., (1971), Recent Trends in Collective Bargaining in the Netherlands, International Labour Review, Vol.110, pp.49-60.

Albeda, W., (1985), The Netherlands, in: Collective Bargaining in Industrialised Market Economies, International Labour Office, Geneva.

Albeda, W., W. Dercksen, (1989), Arbeidsverhoudingen in Nederland, Samsom, Alphen aan den Rijn.

Amernic, J., (1985), The Role of Accounting in Collective Bargaining, Accounting Organizations and Society, Vol.10, pp.227-253.

Amernic, J., (1988), Accounting Disclosure and Industrial Relations: A Review Article, The British Accounting Review, Vol.20, pp.141-157.

Amernic, J., (1989), The Management Accountant and Collective Bargaining, CMA Magazine, Vol.63, pp.28-32. 
Amernic, J., N. Aranya, (1990), Accounting Information and the Outcome of Collective Bargaining: Some Exploratory Evidence, Behavioral Research in Accounting, Vol.2, pp.1-31.

Amernic, J., R. Craig, (1992), Employer Equivocality and Union Heterogeneity as Determinants of the Role of Accounting in Collective Bargaining. Accounting Auditing \& Accountability Journal, Vol.5, pp.60-79.

Anderson, R., (1981), The Usefulness of Accounting and Other Information Disclosures in Corporate Annual Reports to Institutional Investors in Australia, Accounting and Business Research, Vol.11, pp.259-265.

Antle, R., (1982), The Auditor as an Economic Agent, Journal of Accounting Research, Vol.20, pp.503-527.

Arens, A.A., J.K. Loebbecke, (2000), Auditing: An Integrated Approach, Prentice-Hall, Englewood Cliffs, NJ.

Amold, J., P. Moizer, (1984), A Survey of the Methods used by UK Investment Analysts to Appraise Investments in Ordinary Shares, Accounting and Business Research, Vol.14, pp.195207.

Arnold, J., P. Moizer, E. Noreen, (1984), Investment Appraisal Methods of Financial Analysts: A Comparative Study of U.S. and U.K. Practices, International Journal of Accounting, Vol.2, pp.1-18.

Arruñada, B., C. Paz-Ares, (1997), Mandatory Rotation of Company Auditors: A Critical Examination, International Review of Law and Economics, Vol.17, pp.31-61.

Ashenfelter, O., G.E. Johnson, (1969), Bargaining Theory, Trade Unions, and Industrial Strike Activity, American Economic Review, Vol.59, pp.35-49.

Baker, H.K., J.A. Haslem, (1973), Information Needs of Individual Investors, Journal of Accountancy, Vol.69, pp.64-69.

Ball, R., C. Smith, (1992), The Economics of Accounting Policy Choice, McGraw-Hill, New York.

Bamberg, G., K. Spremann (eds.), (1989), Agency Theory, Information, and Incentives, Springer-Verlag, Berlin.

Berelson, B., (1971), Content Analysis in Communication Research, Hafner Publishing Company, New York.

Berentsen, J.H.A., J.H. Hoogendoorn, (1981), OR en Sociaal Jaarverslag, Samsom, Alphen aan den Rijn.

Berg, J.E., (1991), Discussion of the Impact of MAS on Auditors' Independence: An 
Experimental Markets Study, Journal of Accounting Research, Vol.29 (Supplement), pp.99-106.

Bhatia, R., (1962), Profits and the Rate of Change in Money Earnings in the United States, 1935-1959, Economica, Vol.28, pp.255-262.

Blanchflower, D., A. Oswald, (1988), Internal and External Influences upon Pay Settlements, British Journal of Industrial Relations, Vol.26, pp.363-370.

Blanchflower, D., A. Oswald, M. Garret, (1990), Insider Power in Wage Determination, Economica, Vol.57, pp.143-170.

Bollen, L.H.H., (1996), Financial Reporting Regulation for Small and Medium Sized Private Firms: An Empirical Analysis of Compliance, Perceptions, Casts and Usefulness, Dissertation, Rijksuniversiteit Limburg, Maastricht.

Booth, A.L., (1995), The Economics of the Trade Union, Cambridge University Press, Cambridge.

Bougen, P.D., (1988), Accounting and Industrial Relations: Some Historical Evidence on their Interaction, Garland Publishing, New York.

Bougen, P.D., (1989), The Emergence, Roles and Consequences of an Accounting-Industrial Relations Interaction, Accounting Organizations and Society, Vol.14, pp.203-234.

Bougen, P., S. Ogden, (1981), Power in Organizations: Some Implications for the Use of Accounting in Industrial Relations, Managerial Finance, Vol.7, pp.22-26.

Bougen, P., S. Ogden, Q. Outram, (1990), The Appearance and Disappearance of Accounting: Wage Determination in the U.K. Coal Industry, Accounting Organizations and Society, Vol.15, pp.149-170.

Brugmans, L.J., (1975), De Arbeidende Klasse in Nederland in de 19e Eeuw: 1817-1870, Spectrum, Utrecht.

Buijink, W., S. Maijoor, R. Meuwissen, A. van Witteloostuijn, (1996), The Role, Position, and Liability of the Statutory Auditor within the European Union, Final Report of a Study Commissioned by DG XV of the European Commission, Office for Official Publications of the European Communities, Luxembourg.

Buijink, W., R. Eken, (1999), The Netherlands, in: S. McLeay (ed.), Accounting Regulation in Europe, MacMillan Press, London.

Cahan, S.F., (1992), The Effect of Antitrust Investigations on Discretionary Accruals: A Refined Test of the Political Costs Hypotheses, The Accounting Review, Vol.67, pp.77-95.

Campbell, J., J.P. Windmuller, (1992), European Labor Unions, Greenwood Press, Westport, CT. 
Carcello, J.V., R.H. Hermanson, N.T. McGrath, (1992), Audit Quality Attributes: The Perceptions of Audit Partners, Preparers, and Financial Statement Users, Auditing: A Journal of Practice and Theory, Vol.11, pp.1-15.

Carruth, A., A. Oswald, (1987), Wage Inflexibility in Britain, Oxford Bulletin of Economics and Statistics, Vol.49, pp.59-78.

Castle, G.R., (1980), Term Lending - A Guide to Negotiating Term Loan Covenants and Other Financial Restrictions, Journal of Commercial Bank Lending, Vol.63, pp.12-18.

CBS, (1984-1991), Monthly Bulletin of Socio-Economic Statistics, Centraal Bureau voor de Statistiek, March, Voorburg.

CBS, (1995), Statistic Yearbook, Centraal Bureau voor de Statistiek, Voorburg.

CBS, (2000), Statistic Yearbook, Centraal Bureau voor de Statistiek, Voorburg.

Chalos, P., J. Cherian, D. Harris, (1991), Financial Disclosure Effects on Labor Contracts: A Nash Analysis, Contemporary Accounting Research, Vol.7, pp.431-448.

Chang, L.S., K.S. Most, (1977), Investor Uses of Financial Statements: An Empirical Study, in: J.K. Courtis (ed.), Corporate Annual Report Analysis, University of New England, Armidale.

Chang, L.S., K.S. Most, (1985), The Perceived Usefulness of Financial Statements for Investors ' Decisions, Florida International University Press, Miami.

Chamberlain, N.W., J.W. Kuhn, (1986), Collective Bargaining, McGraw-Hill, New York.

Chow, C.W., L. Kramer, W.A. Wallace, (1988), The Environment of Auditing, in: AbdelKhalik, A.R., I. Solomon (eds.), Research Opportunities in Auditing: The Second Decade, American Accounting Association, Sarasota.

CICA, (1988), Report of the Commission on Study of the Public's Expectation of Audits (McDonald Commission), Canadian Institute of Chartered Accountants, Toronto.

Citron, D.B., (1992), Accounting Measurement Rules in UK Bank Loan Contracts, Accounting and Business Research, Vol.23, pp.21-30.

Clarke, F., R. Craig, (1991), Juridical Perceptions of the Relevance of Accounting Data in Wage Fixation, British Journal of Industrial Relations, Vol.29, pp.463-483.

Clarke, F., R. Craig, (1992), Serviceability of Accounting Data in Wage Negotiations, Paper presented at the European Accounting Congress, Madrid.

Clarke, F., R. Craig, J. Amernic, (1990), Misplaced Trust in Reliance on Published Accounting Data for Wage Negotiations: An International Perspective, International Journal of Accounting, Vol.26, pp.184-201. 
Coase, R.H., (1937), Nature of the Firm, Economica, Vol.4, pp.386-405.

Cooper, D., S. Essex, (1977), Accounting Information and Employee Decision Making, Accounting, Organizations and Society, Vol.2, pp.201-217.

Craft, J.A., (1981), Information Disclosure and the Role of the Accountant in Collective Bargaining, Accounting, Organizations and Sociery, Vol.6, pp.97-107.

Craft, J. A., (1984), A Reply to Maunders and Foley, Accounting, Organizations and Society, Vol.9, pp.107-108.

Craswell, A.T., (1997), Threats to Auditor Independence: The Case of Non-Audit Services, Working Paper, University of Sydney.

Cullinan, C.P., M.W. Clark, J.A. Knoblett, (1994), Accounting Information and Collective Bargaining: A Literature Review and Research Framework, Journal of Accounting Literature, Vol.13, pp.44-80.

Cullinan, C.P., J.A. Knoblett, (1994), Unionization and Accounting Policy Choices: An Empirical Examination, Journal of Accounting and Public Policy, Vol.13, pp.49-78.

Day, J.F.S., (1986), The Use of Annual Reports by UK Investment Analysts, Accounting and Business Research, Vol.16, pp.295-307.

Dassen, R.J.M., (1989), Leer van het Gewekte Vertrouwen: Agency avant-la-Lettre, Maandblad voor Accountanty en Bedrijfseconomie, Vol.63, pp.341-352.

Dassen, R.J.M., (1995), Audit Quality: An Empirical Study of the Attributes and Determinants of Audit Quality Perceptions, Dissertation, Rijksuniversiteit Limburg, Maastricht.

DeAngelo, L.A., (1981), Auditor Size and Audit Quality, Journal of Accounting and Economics, Vol.3, pp.183-199.

DeAngelo, L.E., (1990), Equity Valuation and Capital Control, The Accounting Review, Vol.65, pp. $93-112$.

DeAngelo, H., L.E. DeAngelo, (1991), Union Negotiations and Corporate Policy: A Study of Labor Concessions in the Domestic Steel Industry during the 1980s, Journal of Financial Economics, Vol.30, pp.3-43.

Deegan, C., M. Rankin, (1999), The Environmental Reporting Expectations Gap: Australian Evidence, The British Accounting Review, Vol.31, pp.313-346.

Demski, J.S., (1980), Information Analysis, Addison-Wesly Publishing Co, Reading MA.

Dhaliwal, D., (1980), The Effect of the Firm's Capital Structure on the Choice of Accounting Methods, The Accounting Review, Vol.55, pp.78-84. 
Dickens, W., L. Katz, (1987), Inter Industry Wage Differences, In K. Lang, J. Leonard (eds.), Unemployment and the Structure of Labor Markets, Basil Blackwell, New York.

Dijksma, J., M. Hoogendoorn, (1993), European Financial Reporting: The Netherlands, Routledge, London.

Dopuch, N., R.R. King, (1991), The Impact of MAS on Auditors' Independence: An Experimental Market Study, Journal of Accounting Research, Vol.29 (Supplement), pp.60-98.

Duke, J., H. Hunt, (1990), An Empirical Examination of Debt Covenant Restrictions and Accounting Related Debt Proxies, Journal of Accounting and Economics, Vol.12, pp.45-63.

Elias, N., (1990), The Effect of Financial Information Symmetry on Conflict Resolution: An Experiment in the Context of Labor Negotiations, The Accounting Review, Vol.65, pp.606-623.

Epstein, M., (1975), The Usefulness of Anmual Reports to Corporate Shareholders, Los Angeles, California State University.

Epstein, M.J., M.L. Pava, (1993), The Shareholder's Use of Corporate Anmual Reports, Greenwich, JAI Press.

Faith, R.L., J.D. Reid, (1987), An Agency Theory of Unionism, Journal of Economic Behavior and Organisation, Vol.8, pp.39-60.

Fama, E.F., M.C. Jensen, (1983a), Seperation of Ownership and Control, The Journal of Law and Economics, Vol.26, pp.301-326.

Fama, E.F., M.C. Jensen, (1983b), Agency Problems and Residual Claims, The Journal of Law and Economics, Vol.26, pp.327-350.

Flint, D., (1988), Philosophy and Principles of Auditing: An Introduction, MacMillan, London.

FNV, (1976), Open Boek: Een Nota over de Behoefte van Werknemers aan Informatie over hun Onderneming, Federatie Nederlandse Vakbeweging, Amsterdam.

Foley, B.J., K.T. Maunders, (1979), Accounting Information Disclosure and Collective Bargaining, Holmes and Meier Publishers, New York.

Foster, G., (1986), Financial Statement Analysis, Prentice-Hall, Englewood-Cliffs, NJ.

Frank, N.M., A.K. Talwar, (1988), The Accountant's Role in Labor Negotiations, The CPA Journal, Vol.58, pp.56-62.

Gloeck, J.H., H. de Jager, (1993), The Audit Expectation Gap in the Republic of South Africa, School of Accountancy, University of Pretoria.

Goggans, T.P., (1964), The Accountant's Role in Collective Bargaining, The Accounting 
Review, Vol 39, pp.627-630.

Gorman, B., G. Ansong, B. Hamby, (2000), Auditor Independence: Perceptions of Chartered Accountants, Working Paper, Saint Mary's University, Halifax.

Gray, S.J., L.B. McSweeney, J.C. Shaw, (1984), Information Disclosure and the Multinational Corporation, Wiley, Chichester.

Gray, R., D. Owen, K. Maunders, (1987), Corporate Social Reporting: Accounting and Accountability, Prentice-Hall, Englewood Cliffs, NJ.

Green, B.P., T.G. Calderon, B.P. Reider, (1998), A Content Analysis of Teaching Evaluation Instruments Used in Accounting Departments, Issues in Accounting Education, Vol.13, pp.15. 30.

Gregory, M., P. Loban, A. Thomson, (1985), Wage Settlements in Manufacturing, 1979-1984: Evidence from CBI Pay Databank, British Journal of Industrial Relations, Vol.23, pp.339-357.

Gregory, M., P. Loban, A. Thomson, (1986), Bargaining Structure, Pay Settlements and Perceived Pressures in Manufacturing 1979-1984: Further Analysis from the CBI Databank, British Journal of Industrial Relations, Vol.24, pp.215-232.

Gregory, M., P. Loban, A. Thomson, (1987), Pay Settlements in Manufacturing Industry, 1979 1984: A Micro Data-study of the Impact of Product and Labour Market Pressures, Oxford Bulletin of Economics and Statistics, Vol.49, pp.129-150.

Griffin, P.A., (1987), Usefulness to Investors and Creditors of Information Provided by Financial Reporting, Financial Accounting Standards Board, Connecticut.

Gwilliam, D.R., (1987), The Auditor, Third Parties, and Contributory Negligence, Accounting and Business Research, Vol.17, pp.25-35.

Haren, I. van, (1982), De Ondernemingsraad, Kluwer, Deventer.

Harris, K.L., (1996), Content Analysis in Negotiation Research: A review and guide, Behavior Research Methods, Instruments and Computers, Vol.28, pp.458-467.

Hartmann, F.G.H., (1997), Accounting for Performance Evaluation: Effects of Uncertainty on the Appropriateness of Accounting Performance Measures, Dissertation, University Maastricht, Maastricht.

Hassink, H.F.D., (1993), De Rol van de Accountant in Collectief Arbeidsvoorwaardenoverleg. Tijdschrift voor Bedrijfsadministratie, Vol.97, pp.133-149.

Hassink, H.F.D., (1994a), De Pluriforme Rol van Financielle Informatie: Collectief Arbeidsvoorwaardenoverleg als Casus, Maandblad voor Accountancy en Bedrijfseconomie, Vol.68, pp.119-131. 
Hassink, H.F.D., (1994b), Collectief Arbeidsvoorwaardenoverleg als Markt voor Financiēle Informatic, Maandblad voor Accountancy en Bedrijfseconomie, Vol.68, pp.165-178.

Hassink, H.F.D., (1994c), CAO's en Winstdelingsregelingen: Nieuwe Werkterreinen voor de Accountant? De Accountant, Vol.101, pp.4-7.

Hassink, H.F.D., (1995), Collectief Arbeidsvoorwaardenoverleg en Earnings Management, Bedrijfskunde, Vol.67, pp.78-86.

Hassink, H.F.D., (2000), On the Role of Accounting and Auditing in Employee Contracting: Some Evidence for the Netherlands, The European Accounting Review, Vol.9, pp.265-284.

Hayes, B., (1984), Unions and Strikes with Asymmetric Information, Journal of Labor Economics, Vol.2, pp.57-83.

Healy, P., (1985), The Impact of the Bonus Schemes on the Selection of Accounting Principles, Journal of Accounting and Economics, Vol.7, pp.85-107.

Hen, P.E. de, J.G. Berentsen, J.W. Schoonderbeek, (1995), Hoofdstukken uit de Geschiedenis van het Nederlandse Accountantsberoep na 1935, Van Gorcum, Assen.

Herziening van het Ondernemingsrecht, (1965), Rapport van de Commissie Ingesteld bij Beschikking van de Minister van Justitie van 8 april 1960 (Commissie Verdam), Staatsuitgeverij, 's-Gravenhage.

Hicks, J.R., (1963), The Theory of Wages, The Macmillan Company, New York.

Hillison, W., M. Kennelly, (1988), The Economics of Nonaudit Services, Accounting Horizons, Vol.2, pp.32-40.

Hirsch, B.T., J.T. Addison, (1986), The Economic Analysis of Unions: New Approaches and Evidence, Hyman, London.

Hirsch, B.T., (1990), Market Structure, Union Rent Seeking, and Firm Profitability, Economics Letters, Vol.32, pp.75-79.

Hollander, M., D.A. Wolfe, (1999), Nonparametric Statistical Methods, Wiley, New York.

Holmes, S., I. Zimmer, (1998), The Structure of Profit Sharing Schemes in Accounting Partnerships, Accounting and Finance, Vol.38, pp.51-70.

Horwitz, B., R. Shabahang, (1971), Published Corporate Accounting Data and General Wage Increase of the Firm, The Accounting Review, Vol.46, pp.243-252.

Humphrey, C., (1991), Audit Expectations, in: Sherer, M., S. Turley (eds.), Current Issues in Auditing, Chapman Publishing, London. 
Humphrey, C.G., Moizer, P. and Turley, S., (1992), The Audit Expectations Gap plus ca Change, plus c'est la Mème Chose, Critical Perspectrives on Accounting, Vol.3, pp.137-162.

Humprey, C., P. Moizer, S. Turley, (1993), The Audit Expectations Gap in Britain: An Empirical Investigation, Accounting and Business Research, Vol.23, pp.395-411.

Hutcheson, G.D., N. Sofroniou, (1999), The Multivariate Social Scientist: Introductory Statistics Using Generalized Linear Models, Sage Publications, London.

LASC, (1999), International Accounting Standards, International Accounting Standards Committee, London.

ICAEW, (1992), The Audit Expectations Gap in the United Kingdom, The Research Board of the Institute of Chartered Accountants in England and Wales, London.

ICAI, (1992), Report of the Commission of Inquiny into the Expectations of Users of Published Financial Statements, Institute of Chartered Accountants in Ireland, Dublin.

International Research Group, (1981), European Industrial Relations, Oxford University Press, New York.

Jackson-Cox, J., J. McQueeny, J.E.M. Thirkell, (1984), The Disclosure of Company Information to Trade Unions: The Relevance of the ACAS Code of Practice on Disclosure, Accounting. Organizations and Society, Vol.9, pp.253-273.

Jenkins, B., (1990), The Auditor's Guide to Bridging the Gap, Accountancy, Vol.167, pp.22-23.

Jensen, M., W. Meckling, (1976), Theory of the Firm: Managerial Behavior, Agency Costs and Ownership Structure, Journal of Financial Economics, Vol.3, pp.305-360.

Joosten, H.F.J., (1989), De Rechtspraak van de Ondernemingskamer, SMO informatic, 'sGravenhage.

Kalachek, E., F. Raines, (1976), The Structure of Wage Differences among Mature Male Workers, Journal of Human Resources, Vol.11, pp.484-506.

Klaassen, J., (1980), An Accounting Court: The Impact of the Enterprise Chamber on Financial Reporting in the Netherlands, The Accounting Review, Vol.55, pp.327-341.

Klaassen, J., (1993), The Institutional Framework of Annual Reporting in the Netherlands, De Accountant, Vol.100, pp.163-165.

Klaassen, J., H. Schreuder, (1980), Het Financiële Jaarverslag van Ondernemingen: Een Onderzoek onder Gebruikers, Stenfert Kroese, Leiden.

Kleiner, M.M., M.L. Bouillon, (1988), Providing Business Information to Production Workers: Correlates of Compensation and Profitability, Industrial and Labor Relations Review, Vol.41, 
pp.605-617.

Knapp, M., (1985), Audit Conflict: An Empirical Study of the Perceived Ability of Auditors to Resist Management Pressure, The Accounting Review, Vol.40, pp.202-211.

Kochan, T.A., (1980), Collective Bargaining and Industrial Relations: From Theory to Policy and Practice, R.D. Irwin, Homewood, Illinois.

Kok, W., (1975a), De Maatschappelijke Behoefte aan Ondernemingsinformatie, in: Het Beroep onder de Loep, Verslag van Accountantsdag 1975, NIVRA geschrift no.15, pp.11-14 en pp.3241, Nederlands Instituut van Registeraccountants, Amsterdam.

Kok, W., (1975b), De Maatschappelijke Behoefte aan Ondernemingsinformatie, De Accountant, Vol.49, pp.422-424.

Konings, J., E. Labro, F. Roodhooft, (1998), Earnings Management and Trade Union Activity: Results for Belgium, Working Paper, Katholieke Universiteit Leuven, Leuven.

KPMG, (1991), Dutch Legislation on Annual Reporting, KPMG Klynveld, Amsterdam.

Krippendorf, K., (1980), Content Analysis: An Introduction to its Methodology. Sage Publications, Beverly Hills.

Kumar, P, (1972), Differentials in Wage Rates of Unskilled Labor in Canadian Manufacturing Industries, Industrial and Labor Relations Review, Vol.26, pp.631-645.

Laughlin, R., R. Gray, (1988), Financial Accounting: Method and Meaning, VNR, London.

Lee, C.W.J., Z. Gu, (1998), Low Balling, Legal Liability and Auditor Independence, The Accounting Review, Vol.73, pp.533-556.

Lee, F., C. Peterson, (1997), Content Analysis of Archival Data, Journal of Consulting and Clinical Psychology, Vol.65, pp.959-969.

Lee, T.A., D.P. Tweedie, (1975a), Accounting Information: An Investigation of Private Shareholder Understanding, Accounting and Business Research, Vol.5, pp.3-17.

Lee, T.A., D.P. Tweedie, (1975b), Accounting Information: An Investigation of Private Shareholder Usage, Accounting and Business Research, Vol.5, pp.280-291.

Lee, T.A., D.P. Tweedie, (1976), The Private Shareholder: His Sources of Financial Information and his Understanding of Reporting Practices, Accounting and Business Research, Vol.6, pp.304-314.

Leftwich, R., (1983), Accounting Information in Private Markets: Evidence from Private Lending Agreements, The Accounting Review, Vol.58, pp.23-42. 
Lennox, C., (1998), Bankruptcy, Managerial Behaviour and Audit Failure: Evidence from the UK 1987-1994, Working Paper, University of London, London.

Lever, M.H.C., (1993), Union Wage Formation and (Un)employment, Dissertation, Rijksuniversiteit Limburg, Maastricht.

Lewis, N.R., L.D. Parker, P. Sutcliffe, (1984), Financial Reporting to Employees: The Pattern of Development 1919-1979, Accounting, Organizations and Society, Vol.9, pp.275-289.

Liberty, S.E., J.L. Zimmerman, (1986), Labor Union Contract Negotiations and Accounting Choices, The Accounting Review, Vol.61, pp.692-712.

Limperg Instituut, (1987), Opvattingen over Accountants, Amsterdam.

Lipsey, R., M. Steuer, (1961), The Relation Between Profits and Wage Rates, Economica, Vol.27, pp.137-155.

Magee, R.P., M.C. Tseng, (1990), Audit Pricing and Independence, The Accounting Review, Vol.62, pp.315-336.

Maijoor, S.J., (1991), The Economics of Accounting Regulation, Dissertation, Rijksuniversiteit Limburg, Maastricht.

Martinez Ramos, M., (2000), Usefulness of Accounting Reporting for Internal User. Empirical Evidence, Working Paper, University Jaume I, Castellon, Spain.

Matsumara, E., K. Subramanyam, R. Tucker, (1997), Strategic Auditor Behaviour and GoingConcern Decisions, Journal of Business Finance and Accounting, Vol.24, pp.727-758.

Maunders, K.T., (1981), Employee Reporting, in: T.A Lee (ed.), Developments in Financial Reporting, Philip Allan, Oxford.

Maunders, K.T., (1984), Employment Reporting: An Investigation of User Needs, Measurement and Reporting Issues and Practice, The Institute of Charted Accountants in England and Wales, London.

Mautz, R.D., (1990), Inflation-adjusted Disclosures and the Determination of Ability to Pay in Collective Bargaining, Accounting, Organizations and Society, Vol.15, pp.273-295.

Mautz, R.D. F.M. Richardsen, (1992), Employer Financial Information and Wage Bargaining: Issues and Evidence, Labor Studies Journal, Vol.17, pp.35-52.

McBarnet, D., S. Weston, C. Whelan, (1993), Adversary Accounting: Strategic Uses of Financial Information by Capital and Labour, Accounting, Organizations and Society, Vol.18, pp.91-100.

McKinley, S., K. Pany, P.M.J. Reckers, (1985), An Examination of the Influence of CPA Firm 
Type, Size, and MAS Provision to Loan Officer Decisions and Perceptions, Journal of Accounting Research, Vol.23, pp.887-896.

Mertens, G.M.H., (1997), The Impact of Changes in Financial Reporting Regulation on Financial Accounting Method Choice, Dissertation, University Maastricht, Maastricht.

MSZW, (1992a), Ministry of Social Affairs and Employment, DCA/AFD.CAO/ Ondernemings cao's op SBI-code-BIR-29/06/92, Den Haag.

MSZW, (1992b), Ministry of Social Affairs and Employment, DCA/AFD.CAO/ Bedrijfstakcao's op SBI-code-BIR-29/06/92, Den Haag.

MSZW. (1999a), Ministry of Social Affairs and Employment, CRS514/Ondernemingscao's op naam/30/3/1999, Den Haag.

MSZW, (1999b), Ministry of Social Affairs and Employment, CRS512/Bedrijfstakcao's op naam/30/3/1999. Den Haag.

MSZW, (2000), Ministry of Social Affairs and Employment, Arbeidsinspectie, Voorjaarsrapportage CAO-afspraken 2000, May 2000, Den Haag.

Moizer, P., (1991), Independence, in: Sherer, M., S. Turley (eds.), Current Issues in Auditing, Chapman Publishing, London.

Monroe, G.S., D.R. Woodcliff, (1994), An Empirical Investigation of the Audit Expectations Gap: Australian Evidence, Accounting and Finance, Vol.34, pp.47-86.

Moret Emst \& Young, (1994), Current Netherlands Accounting and Reporting Rules, Rotterdam.

Morishima, M., (1991), Information Sharing and Collective Bargaining in Japan: Effects on Wage Negotiation, Industrial and Labor Relations Review, Vol.44, pp.469-485.

Moser, C.A., G. Kalton, (1986), Sunvey Methods in Social Investigation, Basic Books, New York.

Mueller, G.G., L. Kelly, (1991), Introductory Financial Accounting, Prentice Hall, Englewood Cliffs, NJ.

Nederlandse Jurisprudentie (1978), Case nr. 442, pp.1510-1514, Tjeenk Willink, Zwolle.

Nederlandse Jurisprudentie (1981), Case nr. 259, pp.857-858, Tjeenk Willink, Zwolle.

Nickell, S., S. Wadhwani, (1990), Insider Forces and Wage Determination, The Economic Journal, Vol.100, pp.496-509.

NIVRA, (1972), Act on Annual Accountants of Enterprises, NIVRA Geschrift no. 6, Nederlands 
Instituut van Registeraccountants, Amsterdam.

NIVRA, (1992), Kwaliteit, Discussienota Mei 1992: Een Integrale Conceptie voor de Kwaliteitsbevordering van Dienstverlening door Accountants, Nederlands Instituut van Registeraccountants, Amsterdam.

NIVRA, (1995), Gedrags- en Beroepsregels Registeraccountants, Koninklijk Nederlands Instituut van Registeraccountants, Amsterdam.

NIVRA, (2000), Richtlijnen voor de Accountantscontrole, Koninklijk Nederlands Instituut van Registeraccountants, Amsterdam.

Nobes, C., R. Parker, (2000), Comparative International Accounting, Financial Times / Prentice Hall / Pearson Education, Essex, England.

Oakes, L.S., M.A. Covaleski, (1998), A Historical Examination of the Use of Accounting. Based Incentive Plans in the Structuring of Labor-Management Relations, Accounting. Organizations and Society, Vol.19, pp.579-599.

Ogden, S., P. Bougen, (1985), A Radical Perspective of the Disclosure of Accounting Information to Trade Unions, Accounting, Organizations and Society, Vol.10, pp.211-224.

Oorschot, J. van, (1996), Dossier DAF, Kempen Group, Eindhoven Airport.

Oppenheim, A.N., (1992), Questionnaire Design, Interviewing and Attitude Measurement, Pinter, London.

Oswald, A.J., P.J. Turnbull, (1985), Pay and Employment Determination in Britain: What are Labour 'Contracts' Really Like?, Oxford Review of Economic Policy, Vol.1, pp.80-97.

Owen, D.L., Lloyd, A., (1985), The Use of Financial Information by Trade Union Negotiators in Plant Level Collective Bargaining, Accounting, Organizations and Society, Vol.10, pp.329-350.

Palmer, J.R., (1977), The Use of Accounting Information in Labour Negotiations, National Association of Accountants, New York.

Pany, K., P. M.J. Reckers, (1984), Non-audit Services and Auditor Independence: A Continuing Concern, Auditing: A Journal of Practice and Theory, Vol.65, pp.89-97.

Pany, K., P.M.J. Reckers, (1988a), An Examination of the Influence of CPA Firm Type, Size and MAS Provision on Loan Officers Decisions and Perceptions, Journal of Accounting Research, Vol.23, pp.887-896.

Pany, K., P. M.J. Reckers, (1988b), Auditor Performance of MAS: A Study of its Effects on Decisions and Perceptions, Accounting Horizons, Vol.2, pp.31-38.

Parkash, M., C.F. Venable, (1993), Auditee Incentives for Auditor Independence: The Case of 
Non-audit Services, The Acounting Review, Vol.68, pp.113-133.

Parker, L.D. (ed.), (1988), Financial Reporting to Employees: From Past to Present, Garland Publishing Inc., New York.

Parker, L.D., K.R. Ferris, D.T. Otley, (1988), Accounting for the Human Factor, Prentice Hall, Sydney.

Pedhazur, E.J., L. Pedhazur-Schmelkin, (1991), Measurement, Design and Analysis: An Integrated Approach, Eribaum, Hillsdale.

Peel, D.A., P.F. Pope, (1984), Corporate Accounting Data, Capital Market Information and Wage Increase of the Firm, Journal of Business Finance and Accounting, Vol.11, pp.177-188.

Pope, P.F., D.A. Peel, (1981), Information Disclosure to Employees and Rational Expectations, Journal of Business Finance and Accounting, Vol.8, pp.139-146.

Porter, B.A., (1991), The Audit Expectation-performance Gap - A Contemporary Approach, Pacific Accounting Review, Vol.3, pp.1-36.

Porter, B.A., (1993), An Empirical Study of the Audit Expectation-Performance Gap, Accounting and Business Research, Vol.24, pp.49-68.

Press, E., J. Weintrop, (1990), Accounting-based Constraints in Public and Private Debt Agreements: Their Association with Leverage and Impact on Accounting Choice, Journal of Accounting and Economics, Vol.12, pp.64-95.

Press, E., J. Weintrop, (1991), Financial Statement Disclosure of Accounting-based Debt Covenants, Accounting Horizons, Vol.5, pp.64-74.

Ramondt, J., (1981), The Netherlands, in: International Handbook of Industrial Relations: Contemporany Developments and Research, A.A. Blum (ed.), Aldwyck Press, London.

Ramsay, I., B.K. Sidhu, (1998), Accounting and Non-Accounting Based Information in the Market for Debt: Evidence from Australian Private Debt Contracts, Accounting and Finance, Vol.38, pp:197-221.

Rees, B., (1995), Financial Analysis, Prentice Hall, London.

Reynaerts, W.H.J., A.G. Nagelkerke, (1986), Arbeidsverhoudingen, Theorie en Praktijk, Stenfert Kroese, Leiden.

Rojer, M., (1996), CAO-Onderhandelingen: Een Voorspelbaar, Logisch en Rationeel Proces?, Dissertation, Universiteit van Amsterdam, Thesis Publishers, Amsterdam.

Salamon, M., (1998), Industrial Relations: Theory and Practice, Prentice Hall, New York. 
Sanders, P., R. Burgert, (1977), De Jaarrekening Nierwe Stijl, Samsom, Alphen aan den Rijn.

Schilder, A., (1994a), Onafhankelijkheid van Accountants: Frisse Blik en Vers Bloed, Gesprek met Johan Stekelenburg, De Accountant, Vol.100, pp.321-324.

Schilder, A., (1994b), Onafhankelijkheid van Accountants: Maak het Debat Breder, een Gesprek met A.A. Westerlaken, De Accountant, Vol.100, pp.384-386.

Schilder, A., (1994c), Auditor Independence: An Exploratory Study on Some Core Issues of Accountants' Ethics, Dissertation, Rijksuniversiteit Groningen, Wolters-Noordhoff, Groningen.

Schroeder, M.S., I. Solomon, D. Vickrey, (1986), Audit Quality, The Perceptions of AuditCommittee Chairpersons and Audit Partners, Auditing: A Journal of Theony and Practice, Vol.67, pp.86-94.

Shockley, R.A., (1981), Perceptions of Auditor Independence: An Empirical Analysis, The Accounting Review, Vol.56, pp.785-800.

Siegel, S., N.J. Castellan, (1988), Nonparametric Statistics for the Behavioral Sciences, McGraw-Hill, Englewood Cliffs, NJ.

Slichter, S, (1950), Notes on the Structure of Wages, Review of Economics and Statistics, Vol.32, pp.80-91.

Sparks, G.R., D.A. Wilton, (1971), Determinants of Negotiated Wage Increases: An Empirical Analyses, Econometrica, Vol.39, pp.32-46.

Stekelenburg, J., (1995), Een Tikkeltje te Paars, Accountant?, De Accountant, Vol.101, pp.300301 .

Stokes, D., T.K. Leong, (1988), Restrictive Covenants and Accounting Information in the Market for Convertible Notes: Further Evidence, Accounting and Finance, Vol.28, pp.57-73.

Sucker, P. S. Bychkova, D. Vaivadiene, (2000). Auditor Independence: A Comparative International Analysis, Working Paper, University of London, London.

Summer, M., (1998), Does Mandatory Rotation Enhance Auditor Independence?, Zeitschrift für Wirtschafts- und Sozialwissenschaften, Vol.118, pp.327-359.

Tang, Q., (2000), Auditor Independence in China, Working Paper, University of Western Sydney, Kingswood.

Tang, Q., A. Kilgore, L. Yang, J.Y. Hong, (2000), Auditor-Government Associations and Auditor Independence in China, Working Paper, University of Western Sydney, Kingswood.

Tinker, A.M., (1980), Towards a Political Economy of Accounting: An Empirical Illustration of the Cambridge Controversies, Accounting, Organizations and Society, Vol.5, pp.147-160. 
Toren, J.P. van den, (1996), Achter Gesloten Deuren? CAO-overleg in de Jaren Negentig, Dissertation, Rijksuniversiteit Leiden, Welboom, Amsterdam.

Tracy, J.S., (1987), An Empirical Test of an Asymmetric Information Model of Strikes, Journal of Labor Economics, Vol.5, pp.149-173.

Tracy, L., R.B. Peterson, (1986), A Behavioral Theory of Labor Negotiations-How Well has it Aged?, Negotiation Journal, Vol.2, pp.93-108.

Vanstraelen, A., (2000), The Auditor's Going-Concern Opinion: An Economic Analysis of the Decision Making Process, Dissertation, Universiteit Antwerpen, Antwerpen.

Vergoossen, R.G.A., (1993), The Use and Perceived Importance of Annual Reports by Investment Analysts in the Netherlands, The European Accounting Review, Vol.2, pp.219-244 and pp.579-580.

Vergoossen, R.G.A., (1994), Accounting Changes and the Use of Financial Statements: A Study among Investment Analysts, Dissertation, Vrije Universiteit, Amsterdam.

Voften, H., (1979), Challenges to Financial Reporting in the Netherlands: How Corporate Reporting is Monitored by Social Pressure Groups, Nederlands Instituut van Registeraccountants, Amsterdam.

Voorden, W. van, (ed.), (1981), Arbeidsverhoudingen uit Model: Feiten, Ontwikkelingen, Perspectieven, Samsom, Alphen aan den Rijn.

Voorden, W. van, A.G. Nagelkerke, W.F. de Nijs, (1993), Macht in Banen, Stenfert Kroese, Leiden.

Voorden, W. van, (1984), in: Windmuller, J.P., A. Gladstone (eds), Employer Associations and Industrial Relations: A Comparative Study, Oxford University Press, New York.

Vos, C.J., (1982), Arbeidsbeleid en Arbeidsverhoudingen: Centralisering en Fragmentering in het Arbeidsbeleid, Dissertation, Free University, Amsterdam.

Vries, J. de, (1985), Geschiedenis der Accountancy in Nederlands: Aanvang en Ontplooiing: 1895-1935, Van Gorcum, Assen.

Walton, R.E., R.B. McKersie, (1965), A Behavioral Theory of Labor Negotiations, McGrawHill, New York.

Ward, J.G., (1987), The Use and Usefulness of Governmental Financial Reports: The Perspective of Public Sector Labor Unions, Research in Governmental and Nonprofit Accounting, Vol.3(Part B), pp.215-226.

Waterhouse, J., M. Gibbens, A.J. Richardson, (1993), Strategic Financial Disclosure: Evidence from Labor Negotiations, Contemporary Accounting Research, Vol.9, pp.526-550. 
Watts, R., (1977), Corporate Financial Statements, a Product of the Market and Political Process, Australian Journal of Management, Vol.2., pp.53-75.

Watts, R., J. Zimmerman, (1986), Positive Accounting Theory, Prentice Hall, Englewood Cliffs, NJ.

Watts, R., J. Zimmerman, (1990), Positive Accounting Theory: A Ten Year Perspective, The Accounting Review, Vol.65, pp.131-156.

Weber, R.P., (1985), Basic Content Analysis, Sage Publications, Beverly Hills.

Westerlaken, A.A., (1989), Werknemers en de Totstandkoming van Financiele Gegevens, De Accountant, Vol.95, pp.222-225.

Whittington, G., (1986), Financial Accounting Theory: An Over-view, The British Accounting Review, Vol.18, pp.4-41.

Wijngaert, R.F. van de, (1994), Trade Unions and Collective Bargaining in the Netherlands, Dissertation, Free University, Amsterdam, Thesis Publishers, Amsterdam

Windmuller, J.P., (1969), Labor Relations in the Netherlands, Comell University Press, Ithaca, Ney York.

Windmuller, J.P., A. Gladstone, (1984), Employer Associations and Industrial Relations: A Comparative Study, Oxford University Press, New York.

Windmuller, J.P., C. de Galan, A.F. van Zweden, (1990), Arbeidsverhoudingen in Nederland, Het Spectrum, Utrecht.

Wines, G., (1994), Auditor Independence, Audit Qualifications and the Provision of Non-audit Services: A Note, Accounting and Finance, Vol.34, pp.75-86.

Yamaji, H., (1986), Collective Bargaining and Accounting Disclosure: An Inquiry into the Changes in Accounting Policy, International Journal of Accounting, Vol.22, pp.11-24.

Zeff, S., F. van der Wel, K. Camfferman, (1992), Company Financial Reporting: A Historical and Comparative Study of the Dutch Regulatory Process, Elsevier, Amsterdam.

Zeff, S., (1993), The Regulation of Financial Reporting: Historical Development and Policy Recommendations, De Accountant, Vol.100, pp.152-160. 


\section{Nederlandse Samenvatting \\ (Summary in Dutch)}

In studieboeken op het gebied van externe verslaggeving worden vakbonden vaak genoemd als gebruikers van financiële informatie waaronder financiële jaarverslagen. Echter, tot dusverre is in onderzoek op het gebied van externe verslaggeving slechts met mondjesmaat aandacht besteed aan de productiefactor arbeid. Dit geldt in het bijzonder voor vakbonden als vertegenwoordigers van werknemers. Het doel van deze dissertatie is om een bijdrage te leveren aan de exploratie van dit onderzoeksterrein. Hoewel gebruik wordt gemaakt van ideeěn en bevindingen van de arbeidseconomie is de invalshoek van deze dissertatie die van de externe verslaggeving.

Deze dissertatie bestaat uit vier delen. Het theoretische gedeelte beslaat de hoofdstukken 1 tot en met 3. Het empirische gedeelte beslaat de hoofdstukken 4 tot en met 7. Het afsluitende deel wordt gevormd door hoofdstuk 8. Het ondersteunende deel bestaat uit de vier appendices en is opgenomen aan het einde van de dissertatie. Elk van de vier empirische hoofdstukken presenteert een afzonderlijke studie. Hoewel het thema als rode draad door deze dissertatie loopt zijn de vier empirische studies te beschouwen en te lezen als afzonderlijke studies.

Hoofdstuk 1 introduceert vakbonden als potentiële gebruikers van financiële informatie. Daarvoor wordt gekozen voor twee invalshoeken; die van een internationale regelgevende organisatie op het terrein van externe verslaggeving (IASC) en die van leidende studieboeken op dit terrein. Voorts wordt aangegeven dat vakbonden belangrijke spelers zijn op sociaal-economisch vlak. Dit rechtvaardigt een nadere studie naar de percepties van vakbondsonderhandelaren ten aanzien van financiële jaarverslagen, accountants en accountantscontrole. Verder wordt in dit hoofdstuk de plaats van de dissertatie in het onderzoeksveld van de externe verslaggeving besproken en wordt de opbouw van de dissertatie geschetst. De kern van hoofdstuk 1 wordt gevormd door de presentatie van de vier onderzoeksvragen van deze dissertatie, te weten:

(1) Welke rol spelen financiële informatie en accountants in collectieve arbeidsovereenkomsten, en wat verklaart de variatie in deze rol? (Hoofdstuk 4). 
(2) Maken vakbondsonderhandelaren gebruik van financiële jaarverslagen en beschouwen zij financiële jaarverslagen als belangrijk, en zo ja, wat verklaart de variatie in gebruik en gepercipieerd belang? (Hoofdstuk 5).

(3) Hebben vakbondsonderhandelaren een verwachtingskloof ten aanzien van accountants, en zo ja, wat verklaart de variatie in de verwachtingskloof (Hoofdstuk 6).

(4) Wat zijn de percepties van vakbondsonderhandelaren van de onafhankelijkheid van accountants en wat verklaart de variatie in de percepties? (Hoofdstuk 7).

Meer gedetailleerde onderzoeksvragen en hypothesen worden geformuleerd in elk van de empirische hoofdstukken. Aangegeven wordt dat de toegevoegde waarde van deze dissertatie zit in de keuze van de onderzoeksvragen, de onderzochte institutionele setting, de gebruikte data, de onderzoeksopzet en de keuze van de verklarende variabelen.

Hoofdstuk 2 schetst het theoretisch kader van deze dissertatie. Het bespreekt de potentiële relevantie van financiële informatie en accountantscontrole voor vakbondsonderhandelaren. De bespreking beperkt zich tot theorieën die zijn gebruikt in empirische studies op het gebied van de externe verslaggeving. De bevindingen van deze studies worden in hoofdstuk 3 samengevat. Geconcludeerd wordt dat financiële informatie waarschijnlijk relevant is voor vakbondsonderhandelaren omdat deze informatie de prestatie en financiële positie van de onderneming schetst en een indicatie geeft van de loonruimte en bereidheid van de onderneming om tijdens collectief arbeidsvoorwaarden overleg (CAO-overleg) concessies te doen. Ook accountantscontrole is potentieel relevant omdat dit de betrouwbaarheid van de financiële informatie verhoogt. Daarnaast kan het de zekerheid verhogen dat specifieke afspraken tussen de onderneming en vakbonden, zoals winstdelingsregelingen juist zijn nageleefd. Afgesloten wordt met de hypothese dat vakbondsonderhandelaren die onderhandelen op ondernemingsniveau financiële informatie en accountantscontrole bruikbaarder achten dan onderhandelaren die onderhandelen op bedrijfstakniveau. Het empirische deel van deze dissertatie toetst deze hypothese op verschillende wijzen.

Hoofdstuk 3 presenteert een overzicht van de resultaten van voorgaand onderzoek op het raakvlak van externe verslaggeving, accountantscontrole en CAO-overleg. Een van de conclusies van voorgaand onderzoek is dat vakbonden wel degelijk gebruik maken van financiële informatie waaronder jaarverslagen maar dat een aantal kanttekeningen is te plaatsen bij de bruikbaarheid daarvan. Voldoende reden om ook in Nederland de percepties van vakbonden ten aanzien van de relevantie en betrouwbaarheid van financiële informatie waaronder financiële jaarverslagen in kaart te brengen. Voorts blijkt uit voorgaand onderzoek dat Nederlandse vakbondsleiders 
de onafhankelijkheid van accountants als cruciaal beschouwen. Uit hetzelfde onderzoek blijkt dat zij over het algemeen tevreden te zijn met de kwaliteit en reikwijdte van de controle van het financięle jaarverslag maar zij doen suggesties om de onafhankelijkheid van accountants verder te verbeteren. Hoofdstuk 3 sluit af met de identificatie van de vier onderzoeksvragen die centraal staan in de hoofdstukken 4 tot en met 7 waarbij tevens de relatie van deze dissertatie met voorgaande onderzoek op dit terrein wordt geschetst.

Hoofdstuk 4 doet verslag van een empirische studie naar de rol van financiële informatie en accountants(controle) in collectieve arbeidsovereenkomsten (CAO's). Dit is een alternatieve benadering om de relevantie van financièle informatie en accountants(controle) voor vakbonden in kaart te brengen. Voor dit doel zijn CAO's bestudeerd die van kracht waren in $1999(\mathrm{~N}=726)$ en in $1992(\mathrm{~N}=606)$. Kennis over de structuur en inhoud van CAO's kan leiden tot een beter begrip van de rol van financiële informatie en accountants(controle) in regulier CAO-overleg. De resultaten wijzen uit dat de rol van financiële informatie en accountants(controle) in CAO's beperkt is. Er werd geen verschil gevonden in de CAO's over 1999 ten opzichte van 1992. Wel bleek dat financiële informatie vaker een rol speelt in ondernemingsCAO's dan in bedrijfstak-CAO's. Dit onderscheid bleek niet van belang voor wat betreft de rol van accountants(controle) in CAO's. Financiële informatie en accountants(controle) blijken slechts een rol in CAO's te spelen indien partijen afspraken hebben gemaakt over een expliciete winstdelingsregeling voor werknemers. In sommige CAO's blijkt de winstdeling afhankelijk te zijn van de aanwezigheid en de aard van de accountantsverklaring. In deze gevallen heeft niet alleen de keuze van verslaggevingsregels economische consequenties voor belanghebbenden, de accountantsverklaring eveneens. Het tweede deel van het hoofdstuk onderzoekt de kenmerken van expliciete winstdelingsregelingen $(\mathrm{N}=63)$ tussen ondernemingen en vakbonden, zoals aangetroffen in de CAO's over 1999. Geconstateerd werd dat de bonus vaak is gekoppeld aan het bedrijfsresultaat, nettowinst of aan een relatieve prestatie-indicator, zoals rentabiliteit van het eigen vermogen. Vergeleken met winstdelingregelingen op ondernemingsniveau zijn de winstdelingsregelingen op bedrijfstakniveau minder gedetailleerd.

Hoofdstuk 5 onderzoekt of vakbondsonderhandelaren gebruikers zijn van financiële jaarverslagen en gaat na hoe belangrijk zij deze informatie vinden. Daartoe zijn 101 vakbondsonderhandelaren geënquêteerd. Deze dissertatie behandelt de vraag of vakbondsonderhandelaren tijdens $\mathrm{CAO}$-overleg gebruik maken van financiële jaarverslagen en wat het relatieve belang is van het financiële jaarverslag en de winsten verliesrekening. In dit hoofdstuk wordt de variatie in de afhankelijke variabelen verklaard aan de hand van zes onafhankelijke variabelen: onderhandelingsniveau (ondernemings- versus bedrijfstakniveau), het gepercipieerde belang van 
ondernemingsspecifieke informatie ter oriëntatie in regulier CAO-overleg, het gepercipieerde belang van loonruimte als een rechtvaardiging voor het stellen van looneisen, vakbondsvertegenwoordiging, opleidingsniveau van de onderhandelaar, en ervaringsjaren als onderhandelaar. Meer dan $80 \%$ van de respondenten gaf te kennen gebruik te maken van financiële jaarverslagen in regulier CAO-overleg. Van de gebruikers beschouwt $65 \%$ financiële jaarverslagen als een (zeer) belangrijke bron van informatie, en $60 \%$ ziet de winst- en verliesrekening als zodanig. $\mathrm{Zij}$ die op ondernemingsniveau onderhandelen beschouwen financiële jaarverslagen belangrijker dan onderhandelaren op bedrijfstakniveau. Van de overige variabelen hadden vakbondsvertegenwoordiging (FNV of anders) en opleidingsniveau enige verklarende kracht. De enige variabele die positief en significant was in alle analyses is het gepercipieerde belang van ondernemingsspecifieke informatie ter oriëntatie in regulier $\mathrm{CAO}$-overleg. Onderhandelaren die ondernemingsspecifieke informatie ter oriëntatie in regulier CAO-overleg belangrijker vinden, maken vaker gebruik van financiële jaarverslagen en zij beschouwen financiële jaarverslagen en winst- en verliesrekeningen als belangrijker dan andere onderhandelaren.

Hoofdstuk 6 doet verslag van een empirisch onderzoek naar het bestaan en de aard van de kloof tussen de verwachtingen van vakbondsonderhandelaren betreffende enerzijds de reikwijdte en aard van de werkzaamheden van registeraccountants die als externe accountant optreden (verder: accountants) en anderzijds de kwaliteit van hun werkzaamheden. Het bestuderen van deze verwachtingskloof geeft niet alleen inzicht in de percepties van de vakbondsonderhandelaren betreffende deze onderwerpen maar geeft indirect ook inzicht in de betrouwbaarheid van gecontroleerde financiële jaarverslagen, zoals die wordt ervaren door vakbondsonderhandelaren. Immers, de bruikbaarheid van financiële informatie en jaarverslagen voor gebruikers wordt naast de relevantie overigens sterk bepaald door de betrouwbaarheid van deze informatie. De bruikbaarheid van deze informatie kan toenemen door accountantscontrole. De studie in hoofdstuk 6 richt zich op het bestaan en de aard van de verwachtingskloof in de context van CAO-overleg. De verwachtingskloof van 104 Nederlandse vakbondsonderhandelaren is onderzocht. Geprobeerd is de variatie in de verwachtingskloof te verklaren aan de hand van vier onafhankelijke variabelen, te weten: onderhandelingsniveau (ondernemings- versus bedrijfstakniveau), vakbondsvertegenwoordiging, opleidingsniveau van de onderhandelaar, en ervaringsjaren als onderhandelaar. De resultaten wijzen uit dat inderdaad sprake is van een verwachtingskloof en dat deze bestaat uit twee delen: de deficient performance gap en de deficient standards gap. De eerste kloof impliceert dat er bij vakbondsonderhandelaren sprake is van een discrepantie tussen hoe zij denken dat accountants bestaande taken zouden moeten uitvoeren en hun perceptie van de wijze waarop zij deze taken uitvoeren. Met name zijn de vakbondsonderhandelaren van mening dat accountants tekort schieten in hun rol als 
corporate watchdog. Onderhandelaren zijn ontevreden als het gaat om het informeren van de top van de organisatie (management / raad van bestuur, raad van commissarissen) ten aanzien van problemen in de interne organisatie. Datzelfde geldt voor het tijdig inlichten van derden als de organisatie in continuinteitsproblemen is geraakt. De tweede kloof betreft het verschil tussen wat vakbondsonderhandelaren vinden dat behoort tot de taken van de accountant en wat daadwerkelijk de huidige taken van de accountant zijn zoals vastgelegd in wetgeving en richtlijnen. Hierbij gaat het met name om de controle van halfjaar berichten en het informeren van de ondernemingsraad over de controlebevindingen. De variatie in de verwachtingskloven wordt voor slechts een klein deel verklaard door onderhandelingsniveau en de andere onderzochte variabelen.

Hoofdstuk 7 bestudeert de percepties van vakbonden van de onafhankelijkheid van registeraccountants die als externe accountant optreden (verder: accountants). Financiële jaarverslagen zijn slechts dan bruikbaar als potentiële gebruikers ze als relevant en betrouwbaar beschouwen. De betrouwbaarheid hangt onder meer af van de onafhankelijkheid van de accountant. Hoewel accountants hun bestaansrecht ontlenen aan hun onafhankelijkheid heeft voorgaand onderzoek uitgewezen dat er een discrepantie kan bestaan tussen de verwachtingen van gebruikers op het punt van onafhankelijkheid van accountants en hun percepties van de werkelijkheid. Aangezien vakbondshandelaren in grote meerderheid gebruikers van financiële jaarverslagen blijken te zijn (zie hoofdstuk 5) en omdat de perceptie van gebrek aan onafhankelijkheid een belangrijke bedreiging voor de betrouwbaarheid van jaarverslagen is, is het van belang de percepties van vakbondsonderhandelaren in kaart te brengen. Deze studie richt zich op de vraag of vakbondsonderhandelaren accountants onafhankelijk genoeg van hun opdrachtgevers beschouwen. Geprobeerd is de variatie in de afhankelijk variabele te verklaren aan de hand van zeven variabelen: onderhandelingsniveau (ondernemings- versus bedrijfstakniveau), de tolerantie voor het aanbieden van advieswerkzaamheden aan controleklanten, de tolerantie voor het feit dat de klant de audit fee betaalt, het gepercipieerde belang van een verplichte rotatie van accountants bij controleklanten na een aantal jaren, vakbondsvertegenwoordiging, opleidingsniveau van de onderhandelaar, en ervaringsjaren als onderhandelaar. De percepties van 104 Nederlandse vakbondsonderhandelaren zijn onderzocht. De werkelijke onafhankelijkheid is vaker beneden de verwachting ( $37 \%$ ) dan boven de verwachting ( $21 \%$ ), terwijl $42 \%$ van de onderhandelaren vindt dat de onafhankelijkheid aan de verwachting voldoet. Op basis van drie criteria is geconcludeerd dat sprake is van een verwachtingskloof ten aanzien van de onafhankelijkheid van accountants. Het onderhandelingsniveau bleek niet van invloed te zijn bij de verklaring van de variatie van onafhankelijkheid. De variabelen die significant waren in zowel de univariate als de multivariate analyses zijn, de tolerantie voor het feit dat de klant de audit fee betaalt, het gepercipieerde belang van 
een verplichte rotatie van accountants na een aantal jaren, en het opleidingsniveau van de onderhandelaar. Onderhandelaren die een grotere tolerantie hebben voor het feit dat de klant de audit fee betaalt, die een verplichte rotatie van accountants na een aantal jaren minder noodzakelijk achten en die een lager opleidingsniveau hebben, hebben een kleinere verwachtingskloof ten aanzien van de onafhankelijkheid van accountants dan de andere onderhandelaren.

Hoofdstuk 8 vat de bevindingen van de voorgaande hoofdstukken samen, integreert deze en trekt conclusies. Ook worden in hoofdstuk 8 de beperkingen van deze dissertatie besproken. Voorts worden enkele suggesties voor toekomstig onderzoek gedaan en worden enkele beleidsconsequenties van deze dissertatie aangestipt.

Appendix A tot en met $\mathrm{D}$ besluiten deze dissertatie. Appendix A geeft een beknopt overzicht van het ontstaan en de ontwikkeling van externe verslaggeving en accountantscontrole en beschrijft de huidige eisen dienaangaande. Appendix B schetst op hoofdlijnen de context van het Nederlandse systeem van CAO-overleg teneinde de interpretatie van de opzet en uitkomsten van deze dissertatie te verbeteren. Tevens worden kort de belangrijkste spelers aan vakbondskant in deze appendix geïntroduceerd. Appendix C presenteert de inhoud van twee CAO's. Dit is een indirecte wijze om meer inzicht te krijgen in onderwerpen die voor ondernemingen en vakbonden van belang zijn in CAO-overleg. Appendix D bestudeert de percepties van vakbonden, ondernemingen en de rechterlijke macht voor wat betreft het belang voor vakbonden dat financiële jaarverslagen aan de wet dienen te voldoen. Dit geschiedt middels een analyse van een tweetal zaken dat door vakbonden aanhangig is gemaakt bij de Ondernemingskamer van het Gerechtshof te Amsterdam. De analyse wijst uit dat in beide zaken vakbonden zichzelf als 'belanghebbenden' zien voor wat betreft het aanhangig maken van een zaak indien zij van mening zijn dat een jaarrekening niet aan de wettelijke eisen voldoet. Het management van de betrokken ondernemingen interpreteerde het belang van vakbonden anders. In beide zaken verwierpen zij de visie dat vakbonden als 'belanghebbenden' moesten worden beschouwd. Uit de analyse van deze twee rechtszaken blijkt dat vakbonden en het management lijnrecht tegenover elkaar stonden. De Ondernemingskamer oordeelde dat in beide gevallen vakbonden als belanghebbenden bij de jaarrekening kunnen worden beschouwd. De analyse in deze appendix werpt een licht op het strategisch gedrag van partijen in CAO-overleg en op de rol van financiële informatie daarin. 


\section{Curriculum vitae}

Harold Hassink was born on May 29, 1967 in Hengelo (Overijssel), The Netherlands. $\mathrm{He}$ attended secondary school (Atheneum) at Lyceum de Grundel in Hengelo from 1979 to 1985 . He studied business administration at University Maastricht and obtained his masters degree in 1990. In 1990 he started as research assistant at the Maastricht Accounting and Auditing Research and Education Center (MARC) of University Maastricht. From 1991 to 1992 he followed the postgraduate auditing program at University Maastricht and qualified as a registered accountant (RA). From 1993 to 1996 he worked as an assistant professor at Universiteit Maastricht. From May 1996 to August 1997 he worked as a project manager at the Audit Department of Rabobank Nederland and as a part-time assistant professor at Universiteit Maastricht. From 1997 on he is deputy director of the postgraduate programs auditing (PDOA) and controlling (PDOC) of Universiteit Maastricht. He is interested in various research areas in financial analysis and auditing, including earnings forecast quality and the professional ethics of auditors. Part of his work appeared in The European Accounting Review and in various German and Dutch accounting and auditing journals.

Harold Hassink, geboren 29 mei 1967 te Hengelo (Overijssel), slaagde in 1985 voor het eindexamen VWO aan Lyceum de Grundel in Hengelo. Van 1985 tot 1990 studeerde hij bedrijfseconomie aan de Universiteit Maastricht. Na het behalen van het doctoraaldiploma in 1990 trad hij in dienst van de Universiteit Maastricht als assistent-in-opleiding bij Maastricht Accounting and Auditing Research and Education Center (MARC) van de Universiteit Maastricht. In 1992 behaalde hij het accountantsdiploma (RA). Vanaf 1993 werkte hij als universitair docent aan de Universiteit Maastricht. Van mei 1996 tot augustus 1997 was hij projectleider bij de Accountantsdienst van Rabobank Nederland. Vanaf augustus 1997 is hij werkzaam als adjunct-directeur van de postdoctorale opleiding tot registeraccountant (PDOA) en registercontroller (PDOC) van de Universiteit Maastricht. Hij is geïnteresseerd in onderzoek op het gebied van financial analysis en auditing, waaronder de kwaliteit van winstvoorspellingen en de beroepsethiek van accountants. Publicaties van zijn hand verschenen in The European Accounting Review en diverse Duits- en Nederlandstalige tijdschriften op het gebied van accounting en auditing. 
224

Curriculum vitae 

